\title{
CARACTERIZAÇÃO GENÉTICA DE POPULAÇÕES DE CUPUAÇUZEIRO, Theobroma grandiflorum (Willd. ex. Spreng.) Schum., POR MARCADORES MICROSSATÉLITES E DESCRITORES BOTÂNICO- AGRONÔMICOS
}

\author{
RAFAEL MOYSÉS ALVES
}

Tese apresentada à Escola Superior de Agricultura "Luiz de Queiroz", da Universidade de São Paulo, para obtenção do título de Doutor em Agronomia, área de concentração: Genética e Melhoramento de Plantas.

\author{
P I R A C I C A B A \\ Estado de São Paulo - Brasil \\ Dezembro - 2002
}




\title{
CARACTERIZAÇÃO GENÉTICA DE POPULAÇÕES DE CUPUAÇUZEIRO, Theobroma grandiflorum (Willd. ex. Spreng.) Schum., POR MARCADORES MICROSSATÉLITES E DESCRITORES BOTÂNICO- AGRONÔMICOS
}

\author{
RAFAEL MOYSÉS ALVES \\ Engenheiro Agrônomo \\ Orientador: Prof. Dr. ANTONIO VARGAS OLIVEIRA FIGUEIRA \\ Tese apresentada à Escola Superior de \\ Agricultura "Luiz de Queiroz", da Universidade \\ de São Paulo, para obtenção do título de \\ Doutor em Agronomia, área de concentração: \\ Genética e Melhoramento de Plantas. \\ P I R A C I C A B A \\ Estado de São Paulo - Brasil \\ Dezembro - 2002
}




\section{Dados Internacionais de Catalogação na Publicação (CIP) DIVISÃO DE BIBLIOTECA E DOCUMENTAÇÃO - ESALQ/USP}

Alves, Rafael Moysés

Caracteriza ção genétic a de populações de cupuaçuzeiro, Theobroma grand iflorum (Willd. ex. Spreng.) Sc hum., pormarc adores mic rossa télitese descritores botânic o-agronômic os / Rafael Moysés Alves. - - Pira cica ba, 2002.

146 p. : il.

Tese (doutorado) - Escola Superior de Agricultura Luiz de Queiroz, 2002. Bibliografia.

1. Banco de gemoplasma 2. Cupuaçu 3. Marcadorgenético 4. Melhoramento genético vegetal 5. Populações vegetais 6 . Progênie vegetal 7. Reprodução vegetal $\quad 8$. Variação genética em plantas I. Título

CDD 634.6 


\begin{abstract}
À Eliane, minha esposa, e aos nossos filhos Rachel, Moysés, Myrian e Débora, pelo sacrifício, carinho, compreensão e sensibilidade dispendidos para que nossos sonhos fossem atingidos.

OFEREÇO
\end{abstract}

Aos meus pais, Moysés M. Alves (in memorian) e Rachel B. Alves, cujos exemplos de fé, perseverança e coragem são meus guias.

DEDICO 


\section{AGRADECIMENTOS}

A Embrapa Amazônia Oriental pela oportunidade concedida para que eu pudesse realizar este curso.

Ao Professor Dr. Antonio Figueira, pela orientação, generosidade, ensinamentos e incentivo durante o curso.

Ao Centro de Energia Nuclear na Agricultura (CENA/USP) que me acolheu na fase inicial do curso e disponibilizou a infraestrutura do Laboratório de Melhoramento de Plantas.

Ao Professor Dr. Akihiko Ando que incentivou minha vinda à Piracicaba, e prestou orientação durante o primeiro ano do curso.

Ao Departamento de Genética da ESALQ/USP, por ter aceito minha transferência e pelos ensinamentos ministrados.

Ao Eng. Florestal Alexandre Magno Sebbenn pelo auxílio nas análises estatísticas e revisão dos manuscritos, fundamentais para conclusão deste trabalho.

Ao Prof. Dr. Augusto Garcia pelo auxílio nas análises estatísticas multivariadas.

Ao colega Altamir Guidolin pela convivência e troca de experiências durante todo o período de obtenção dos créditos.

Aos colegas do Laboratório de Melhoramento de Plantas Rodrigo Latado, Silvana Creste, Maria Lorena Sereno, Rogério Silva, Ederson Kido, Thiago Benatti, César Paullilo, Cristiane Borges, Henrique Marques, Arthur Bastos, Eva Mamani e Jupará pelos ensinamentos, amizade e pela convivência prazeirosa que conseguiu amenizar até as horas menos favoráveis. 
A Bióloga Angela Artero pela parceria extremamente produtiva que foi iniciada.

Ao colega Oriel F. de Lemos, amigo de todas as horas.

Aos técnicos de laboratório Wlamir, Inês e Raquel pela ajuda fornecida.

Ao colega Eniel Davi Cruz que assumiu os projetos que estavam sob minha responsabilidade na Embrapa, viabilizando minha saída para curso.

Aos demais colegas da Embrapa José R. Quadros Fernandes, Miguel Loureiro, Marcus Vinícius F. da Silva, Paulo de Tarso O. Santiago, José S. Oliveira de Aviz, Antonias Trindade, Mario R. Gomes e as estagiárias Dênmora Araújo e Lucionila Pimentel, que auxiliaram na coleta dos dados de campo, o meu reconhecimento.

Ao Conselho Nacional de Desenvolvimento Científico e Tecnológico (CNPq) pela concessão da bolsa de estudo.

Ao técnico em computação do CENA João Geraldo Brancalion, pelos auxílios computacionais.

A todos os demais amigos e colegas, que de alguma forma contribuíram para a realização deste trabalho, o meu muito obrigado. 


\section{SUMÁRIO}

Página

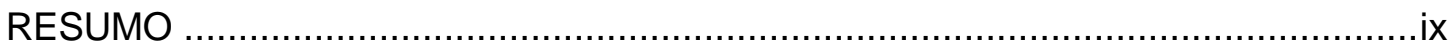

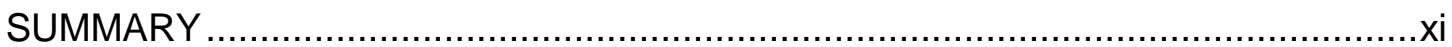

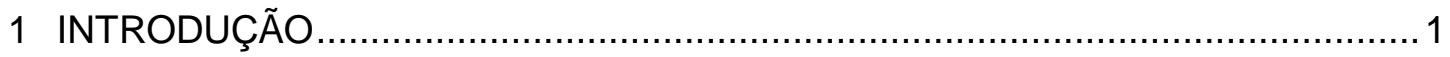

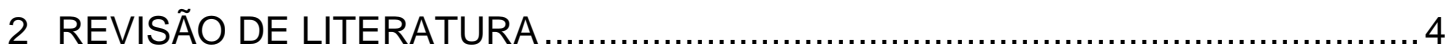

2.1 Características da espécie................................................................. 4

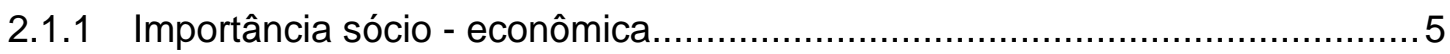

2.1.2 Origem e distribuição geográfica............................................................ 8

2.1.3 Aspectos taxonômicos e botânicos ....................................................... 9

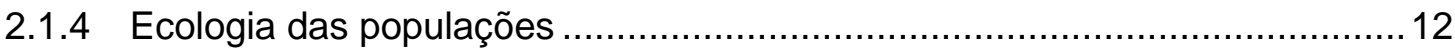

2.1.5 Conservação das populações .......................................................... 15

2.2 Seleção e utilização de descritores botânico-agronômicos ...............................25

2.2.1 Análise multivariada por componentes principais......................................26

2.2.2 Importância relativa dos caracteres para divergência ................................28

2.2.3 Seleção de descritores botânico-agronômicos ...........................................29

2.2.4 Avaliação da eficiência de descarte ....................................................... 32

2.3 Utilização de marcadores moleculares para estudo de divergência genética.....33

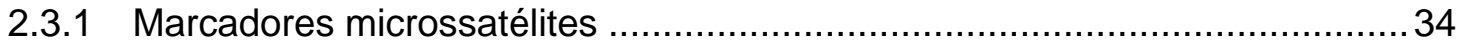

2.3.2 Diversidade genética em populações de plantas ...................................... 38

2.3.3 Correspondência entre distâncias genéticas e fenotípicas ........................... 40

2.3.4 Correspondência entre distância genética e geográfica ............................... 42

3 DIVERSIDADE GENÉTICA EM POPULAÇÕES DE CUPUAÇUZEIRO,

Theobroma grandiflorum (Willd. ex Spreng.) Schum. UTILIZANDO

MARCADORES MICROSSATÉLITES 


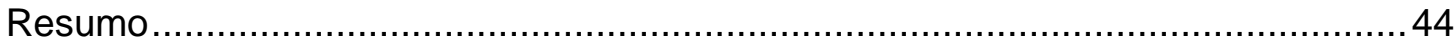

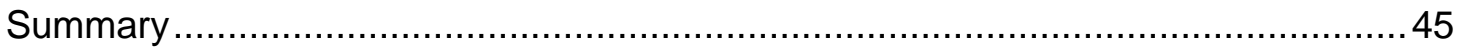

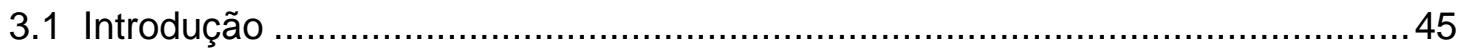

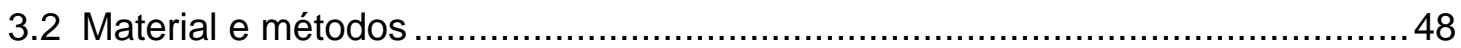

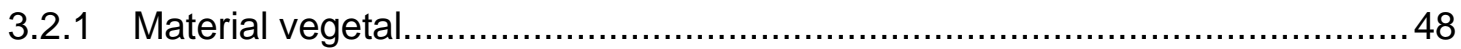

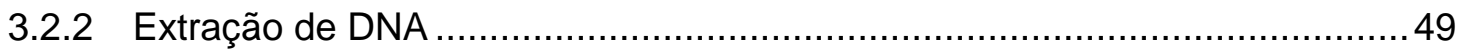

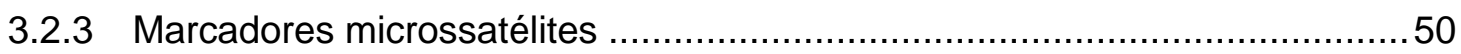

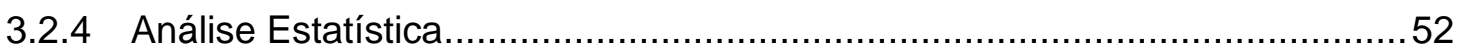

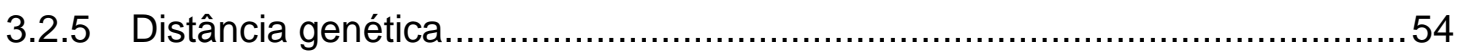

3.2.6 Correlação entre distância genética e distância geográfica............................54

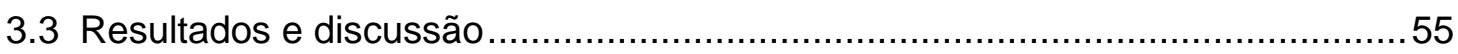

3.3.1 Caracterização dos locos microssatélites em cupuaçuzeiro...........................55

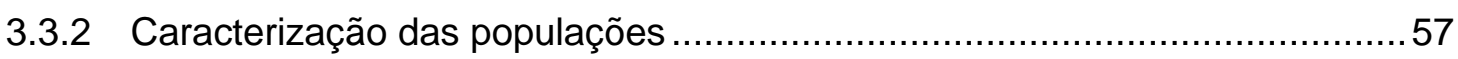

3.3.3 Distribuição da Diversidade Genética Entre e Dentro de Populações ............63

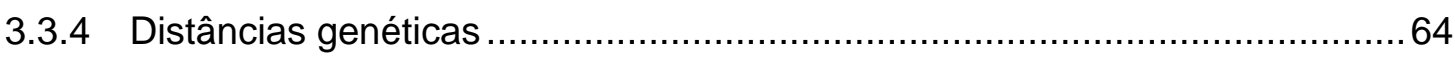

3.3.5 Correlação entre distância genética $x$ distância geográfica .............................65

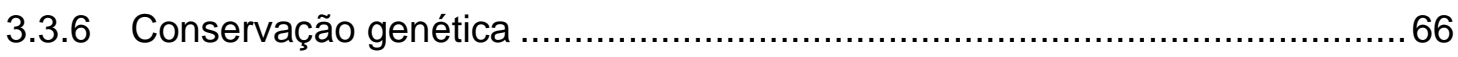

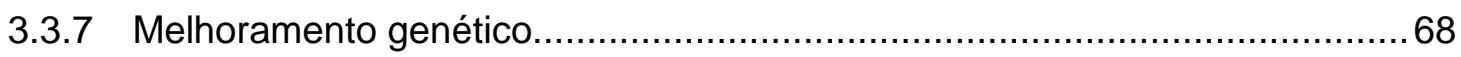

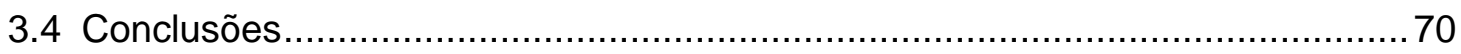

4 SELEÇÃO DE DESCRITORES BOTÂNICO - AGRONÔMICOS PARA CARACTERIZAÇÃO DE GERMOPLASMA DE CUPUAÇUZEIRO, Theobroma grandiflorum (Willd. ex. Spreng.) Schum ......................................................... 73

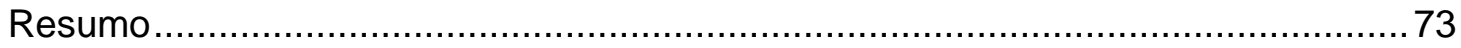

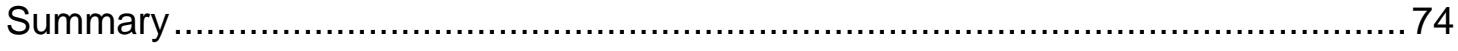

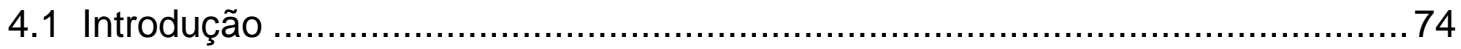

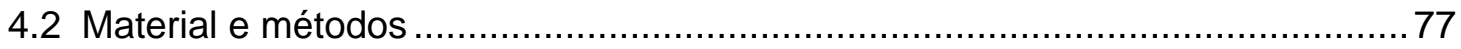

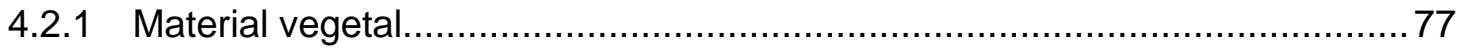

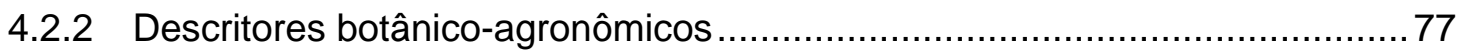

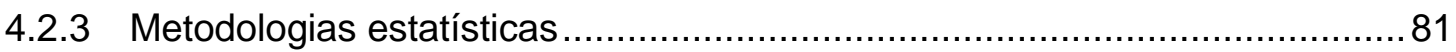

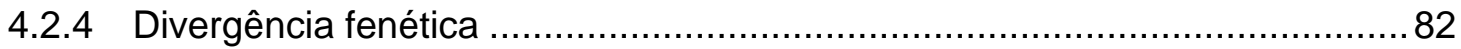

4.2.5 Concordância entre a caracterização genética e fenotípica ........................... 82

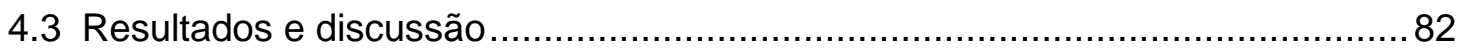

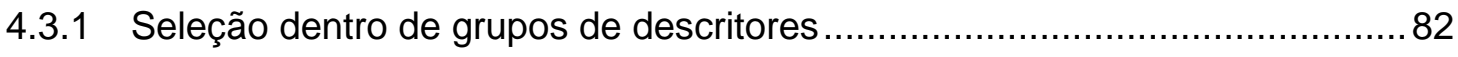


4.3.2 Seleção conjunta de descritores de folha, flor, fruto e agronômicos ..............90

4.3.3 Avaliação da eficiência dos conjuntos selecionados ..................................92

4.3.4 Divergência fenética por marcadores botânico-agronômicos .......................93

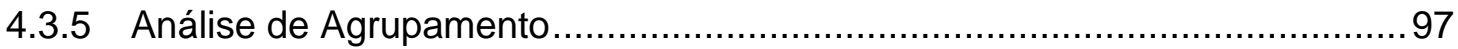

4.3.6 Concordância entre caracterização genética e fenotípica no estudo da diversidade genética ..................................................................... 100

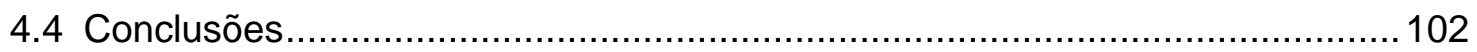

5 SISTEMA DE REPRODUÇÃO EM POPULAÇÃO NATURAL DE CUPUAÇUZEIRO, Theobroma grandiflorum (Willd. ex Spreng.) Schum., COM BASE EM MARCADORES MICROSSATÉLITES .......................................... 104

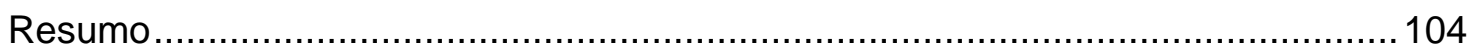

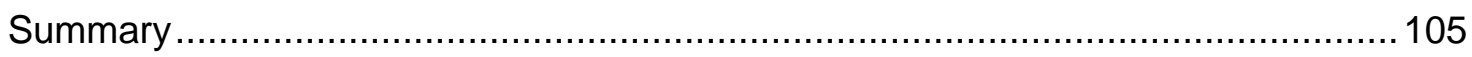

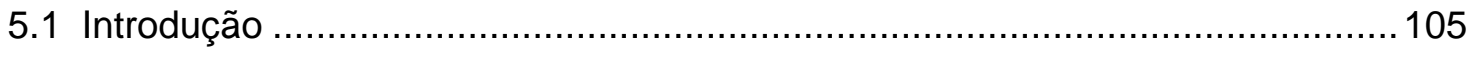

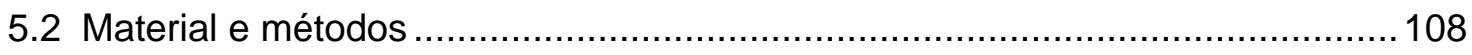

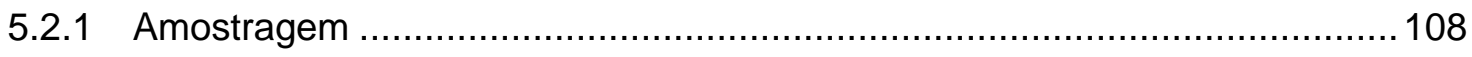

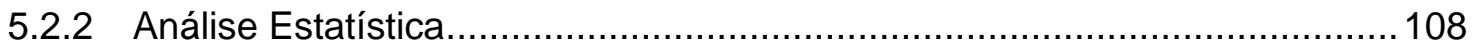

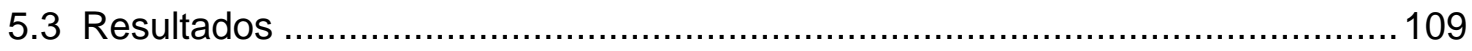

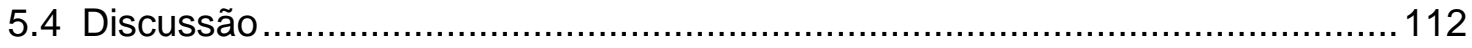

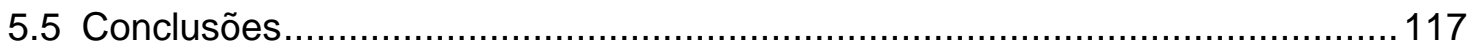

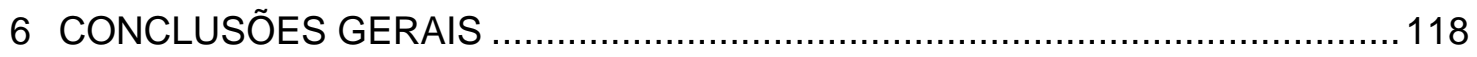

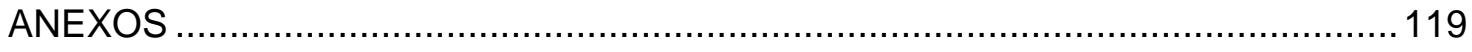

REFERÊNCIAS BIBLIOGRÁFICAS ......................................................... 128 


\title{
CARACTERIZAÇÃO GENÉTICA DE POPULAÇÕES DE CUPUAÇUZEIRO, Theobroma grandiflorum (Willd. ex. Spreng.) Schum., POR MARCADORES MICROSSATÉLITES E DESCRITORES BOTÂNICO-AGRONÔMICOS
}

\author{
Autor: RAFAEL MOYSÉS ALVES \\ Orientador: Prof. Dr. ANTONIO V.O. FIGUEIRA
}

\section{RESUMO}

Este trabalho teve por objetivo caracterizar e comparar a estrutura genética de sete populações de cupuaçuzeiro, Theobroma grandiflorum (Willd. ex Spreng.) Schum., uma fruteira nativa da Amazônia brasileira, utilizando marcadores microssatélites e descritores botânico-agronômicos. Visou também conhecer, preliminarmente, o sistema reprodutivo do cupuaçuzeiro. A estrutura genética das sete populações, sendo três populações naturais, coletadas na suposta área de máxima diversidade da espécie, três populações estabelecidas em Banco Ativo de Germoplasma (BAG), e uma população coletada em plantios comerciais do município de Tomé açu - PA, foi analisada com auxílio de marcadores microssatélites. Foi observada alta variabilidade genética na espécie, ressaltado pelo elevado número de alelos por loco, alto nível de heterozigosidade e divergência entre as populações. A divergência foi mais acentuada entre as populações naturais, em comparação com as populações do Banco de Germoplasma. Essa divergência pode indicar um processo preliminar de diferenciação. Porém, foi mais acentuada entre as populações oriundas de Tucuruí e Nova Ipixuna, corroborando com as indicações que consideram essa região como o centro de máxima diversidade de $T$. grandiflorum. Estes resultados sugerem, como estratégia de conservação in situ, a necessidade de definição de mais de um local para reserva genética, bem como, em relação a conservação ex situ, as coletas devem ser 
realizadas em vários locais. A elevada diversidade genética observada nos plantios comerciais, permite recomendar essas plantações como uma fonte alternativa de genes e genótipos ao programa de melhoramento de $T$. grandiflorum. No BAG foi observada baixa divergência genética entre as populações, sendo que, a maior parte da variabilidade genética encontrava-se dentro das populações. Essa caracterização foi complementada com o emprego de descritores botânico-agronômicos, quando foi observada grande variabilidade para a maioria dos descritores empregados. Houve necessidade, inicialmente, de selecionar dentre as 53 variáveis, aquelas que melhor se prestavam para a caracterização dos acessos. Empregando análises univariada e multivariada por componentes principais, foi possível descartar $64 \%$ das variáveis iniciais, sendo sugerida uma lista mínima de 19 descritores para o cupuaçuzeiro. Com base nessa lista e o emprego da distância Euclideana média, foi obtida uma matriz de dissimilaridade entre os 31 acessos avaliados. Esses acessos foram agrupados pelo método de Tocher e UPGMA, tendo sido obtidos seis grupos de similaridade. A comparação entre as duas caracterizações realizadas no BAG, revelou uma correlação positiva e significativa entre distâncias genéticas e fenotípicas. Preliminarmente foi estudado o sistema de reprodução do cupuaçuzeiro, numa população natural de Nova Ipixuna - PA, sendo utilizadas oito progênies de polinização aberta, com dez indivíduos e oito locos microssatélites polimórficos. Baseado na estimativa da taxa de cruzamento multilocos $\left(\hat{t}_{m}=1,0\right)$ e individual por planta materna, o estudo nessa população sugere que o $T$. grandiflorum é uma espécie predominantemente alógama, com uma pequena percentagem $(5,4 \%)$ de cruzamentos entre parentes. Esse fator tem implicações importantes nas estratégias de conservação in situ e na utilização de progênies oriundas de polinização aberta nos programas de melhoramento. 


\title{
GENETIC CHARACTERIZATION OF CUPUASSU Theobroma grandiflorum (Willd. ex. Spreng.) Schum. POPULATIONS BY MICROSATELLITE MARKERS AND BOTANIC-AGRONOMIC DESCRIPTORS
}

\author{
Author: RAFAEL MOYSÉS ALVES \\ Adviser: ANTONIO V. O.FIGUEIRA
}

\section{SUMMARY}

This work had the objectives to characterize and compare the genetic structure of seven populations of cupuassu, Theobroma grandiflorum (Willd. ex Spreng.) Schum., a fruit tree native to the Brazilian Amazon using microsatellite markers and botanicagronomic descriptors; and to investigate the cupuassu mating system. The genetic structure of seven populations of cupuassu, with three originally collected at the putative center of maximum diversity of the species; three populations established at the active germplasm collection (BAG); and one population colected from commercial plantings were analyzed using microsatellite markers. High genetic variability was observed for the species, demonstrated by the elevated number of alleles per locus; high heterozigosity and divergence between populations. The divergence was more noticeable among natural populations than among populations from the germplasm collection. This divergence might indicate a preliminary process of diversification. However, it was more pronounced between the populations from Tucuruí and Nova Ipixuna, corroborating indications that this region is considered the center of maximum diversity of $T$. grandiflorum. These results suggested as strategy for in situ conservation, the requirement to define more than one site for genetic reserves, large enough to maintain rare alleles in the medium- to long term. For ex situ conservation, sample collection must be conducted in many sites, with low intensity in each site, due to the existing variability witihin population. The high genetic diversity observed in commercail plantings allow to recommend these areas as an alternative source for 
genes and genotypes for the breeding program of $T$. grandiflorum. The characterization of the germplasm populations was complemented using botanic-agronomic descriptors. The large observed variability for most of the evaluated descriptors indicated that the germplasm collection contained high phenotypic diversity. Initially, it was necessary to select from the 53 evaluated variables, those most suitable for characterization of the accessions. Using univariate and multivariate analyses of principal components, it was possible to discard $64 \%$ of the initial variables, and a minimum descriptor list with 19 traits was proposed for cupuassu. Based on the minimum descriptor list, a matrix of dissimilarity was constructed using Euclidean distances. The 31 evaluated cupuassu accessions were grouped using Tocher and UPGMA, into six groups. The comparison betwen the molecular and phenotypic characterization revealed a significant and positive correlation between the genetic and phenotypic distances. The mating system fo cupuassu was studied, based on a natural population from Nova Ipixuna - PA, using eight progenies derived from open-pollinated pods with ten individuals each and eight polymorphic microsatellite loci. Based on the estimation of the multilocus outcrossing rate $\left(\hat{t}_{m}=1,0\right)$ and individual outcrossing rate $(\hat{t}=1.0)$, the results from this population suggested that $T$. grandiflorum is a predominatly outbreeding species, with a small percentage $(5,4 \%)$ of biparental inbreeding. These results have important implications on the in situ conservation strategies and on the use of open-pollinated progenies in breeding programs. 


\section{INTRODUÇÃO}

O cupuaçuzeiro, fruteira nativa da Amazônia brasileira, se transformou nas últimas décadas em um cultivo importante para agricultura do Norte do Brasil.

Como outras espécies de origem amazônica, teve seu processo de domesticação possivelmente iniciado pelos índios, sendo uma das fruteiras mais comumente encontrada nas tribos da Amazônia Oriental que praticavam a agricultura (Kerr \& Clement, 1980).

Até cerca de 20 anos atrás, o mercado para produtos oriundos do cupuaçuzeiro esteve limitado às fronteiras da Amazônia. No entanto, com a abertura do mercado para frutas exóticas tropicais, a nível nacional e internacional, especialmente aquelas oriundas da floresta Amazônica, houve possibilidade de ampliar o cultivo e aumentar a oferta do produto, com conseqüentes benefícios sociais e econômicos para a região, seja pela geração de empregos, como pela redução do êxodo rural. Atualmente mais de 30.000 hectares da cultura já foram implantados na região, com destaque para o estado do Pará, maior produtor nacional, com mais de 14.000 hectares (Homma et al., 2001). Porém a expansão do cultivo já atinge outros estados brasileiros (Venturieri, 1993).

Apesar da grande ênfase que tem sido dada nos últimos anos para a conservação de espécies amazônicas (Kerr \& Clement, 1980; Schultes, 1979), existe pouco conhecimento científico para respaldar essas iniciativas. No caso específico do cupuaçuzeiro, a espécie ainda carece de um maior aprofundamento sobre biologia floral, fluxo gênico, polinizadores e dispersores de sementes, bem como, caracterização e quantificação da variabilidade genética entre e dentro das populações. 
A região amazônica além de ser o centro de máxima diversidade da espécie, se constitui na única reserva de variabilidade genética do cupuaçuzeiro. Porém, além do melhoramento genético da espécie ser ainda incipiente, é restrita a disponibilidade de germoplasma para ser utilizado pelos melhoristas. Além do mais, as populações nativas remanescentes, que poderão servir como fontes de genes e genótipos, estão sofrendo forte erosão genética pela ação antrópica, especialmente no Sul e Sudeste do Pará, onde grande parte da floresta primária foi transformada em pastagem. Há necessidade, portanto, que seja reconhecida e quantificada a divergência genética entre as populações nativas remanescentes, para subsidiar o resgate de acessos das populações mais ameaçadas de extinção, bem como, a identificação de populações com grande variabilidade genética, para que sejam conservadas in situ, na forma de reserva biológica.

Os acessos resgatados servirão para enriquecer as coleções ex situ, necessariamente mantidas à campo, na forma de Banco Ativo de Germoplasma (BAG), visto que as sementes não toleram dessecamento e frio e, portanto, não podem ser conservadas em câmaras frias como a maioria das espécies. Com o enriquecimento das coleções, o programa de melhoramento poderá se estruturar para responder mais eficientemente a demanda dos produtores.

Uma vez conhecida a estrutura e variação genética das populações naturais, haverá necessidade de compará-la como o que se encontra disponível no BAG, para avaliar a necessidade de realização de reamostragens ou novas coletas em áreas ainda não exploradas. Para conhecer a variabilidade intra - e interpopulacional, uma das alternativas é utilizar marcadores moleculares, dentre os quais, os microssatélites têm se destacado para a avaliação e caracterização de germoplasma. Quando essa alternativa não esta disponível, a opção tem sido a caracterização morfológica, com o emprego de descritores fenotípicos.

Como não existe uma lista de descritores padronizada para ser empregada na caracterização do cupuaçuzeiro, os melhoristas empregam variáveis utilizadas principalmente em cacaueiro e outras espécies afins. Porém, a complexidade dessas listas prolonga o tempo de coleta de dados com grande dispêndio de tempo e mão de obra. A análise multivariada por componentes principais permite selecionar os 
descritores mais eficientes. Através desses descritores é possível estimar a distância entre os acessos e agrupar sub-conjuntos mais similares.

Visando contribuir para o entendimento da variabilidade genética do cupuaçuzeiro, o presente estudo foi desenvolvido com o objetivo de caracterizar, com marcadores microssatélites, sete populações de cupuaçuzeiro, estabelecidas em condições naturais, Banco Ativo de Germoplasma (BAG) e plantios comerciais, para que fosse possível quantificar a divergência dentro e entre as populações. A caracterização das populações do BAG foi complementada com a utilização descritores botânico-agronômicos, havendo necessidade, preliminarmente, de selecionar as variáveis mais eficientes, para compor uma lista mínima de descritores. Visou, também, estudar o tipo de sistema de reprodução com dados coletados em progênies de uma população nativa de cupuaçuzeiro, utilizando marcadores microssatélites. 


\section{REVISÃO DE LITERATURA}

\subsection{Características da espécie}

A espécie Theobroma grandiflorum (Willd ex Spreng) Schum, é uma fruteira arbórea nativa da Amazônia brasileira (Figura 1), com excelente potencial de mercado para exploração da polpa, uma mucilagem que envolve as sementes, a qual corresponde a aproximadamente $40 \%$ do peso total do fruto (Calzavara et al., 1984). Até o presente é essa parte do fruto que sustenta todo o fluxo de produção, comercialização e industrialização (Souza et al., 1998).

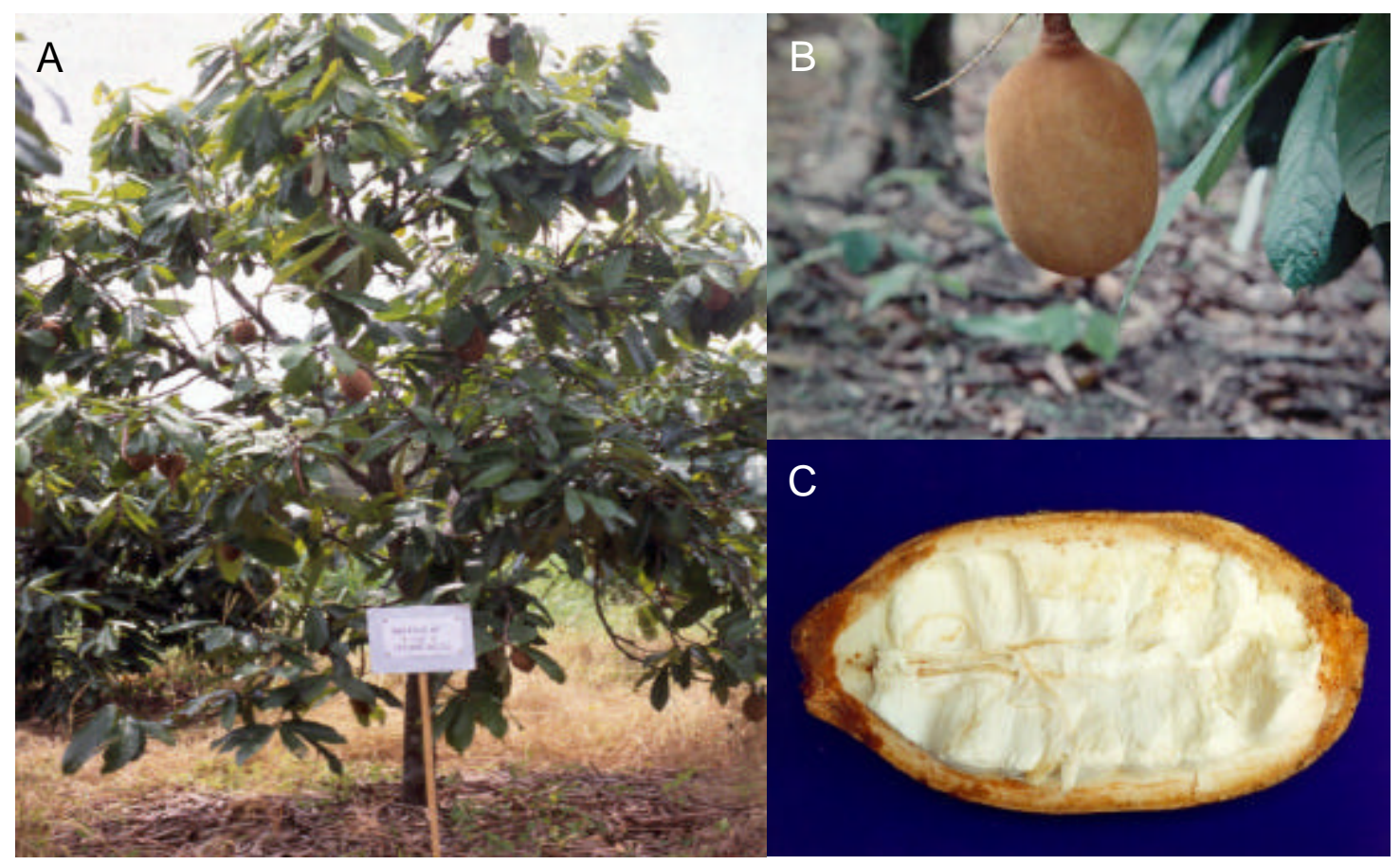

Figura 1 - Aspectos da produção de frutos do cupuaçuzeiro (A) planta em produção; (B) fruto maduro; (C) fruto aberto. 
Vários produtos são fabricados a partir da polpa (Figura 2a), como sucos, sorvetes, cremes, bombons, doces, licores e compotas, além de produtos de beleza (Cavalcante, 1991; Barbosa et al., 1978; Calzavara et al., 1984).

As sementes, que representam cerca de $15 \%$ do peso do fruto, possuem aproximadamente $60 \%$ do seu peso seco constituído de uma fina gordura, de fácil digestibilidade composta principalmente por ácidos oléico e esteárico (Vasconcelos et al., 1975), da qual pode ser obtido um produto muito similar ao chocolate oriundo do cacaueiro (Figura 2b). Ribeiro et al., (1992) também verificaram que essa gordura apresentava, em média, alto ponto de fusão $\left(32,5^{\circ} \mathrm{C}\right)$ e baixo nível de ácidos graxos livres $(0,9 \%)$.

No processo inicial de domesticação, as áreas de plantio foram estabelecidas com sementes oriundas, principalmente, de plantas nativas, face a carência absoluta de materiais de plantação selecionados, o que proporcionou desuniformidade dentro das plantações redundando em baixa produtividade (Alves et al., 1998a; Souza et al., 1998). Porém, involuntariamente, conservou uma amostra importante da variabilidade natural. A renovação dos cultivos com clones e outros materiais selecionados de base genética restrita, deverá promover uma melhor padronização e acréscimo na produtividade, porém contribuirá para a erosão genética do germoplasma que vinha sendo conservado.

\subsubsection{Importância sócio - econômica}

O cultivo do cupuaçuzeiro tem sido realizado basicamente em pequenas propriedades rurais, apesar de existirem médias e grandes plantações, normalmente consorciado a outras culturas. Emprega basicamente mão-de-obra familiar praticamente o ano inteiro, contribuindo para fixação do homem ao campo.

Até a década de 70 toda a produção de cupuaçu era oriunda do extrativismo. A valorização dessa atividade em parte contribuiu para a conservação das populações remanescentes. A partir desse período, teve início a entrada em produção de plantios racionais. $\mathrm{O}$ impacto dessa mudança pode ser verificado atualmente, pois há uma 

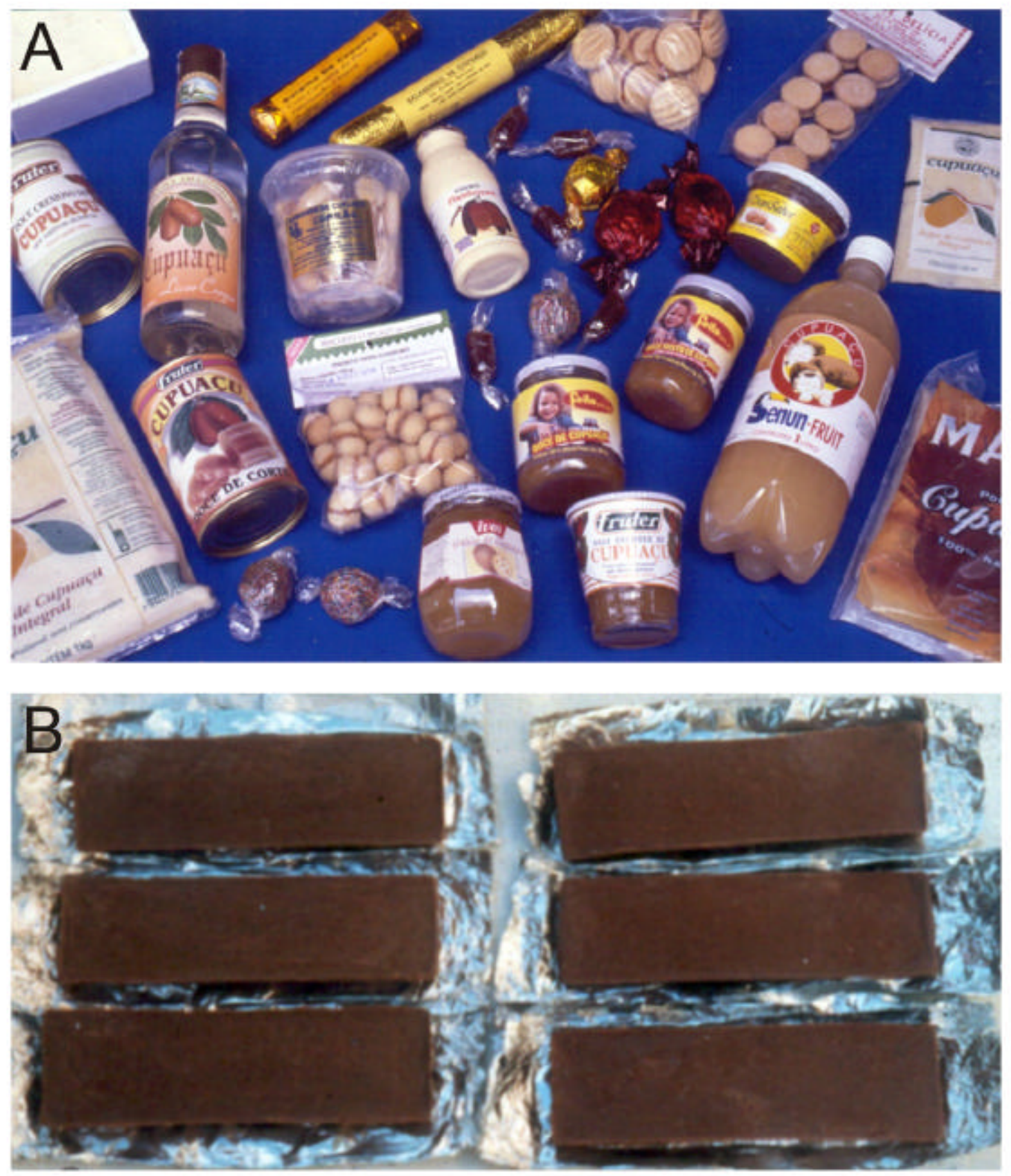

\section{Cupulate ao leite - Cupuaçu - \\ Chocolate ao leite - Cacau -}

Figura 2 - Produtos manufaturados a partir da polpa de cupuaçu (A) e da semente cupulate, e chocolate do cacau (B). 
tendência de queda nos preços do fruto in natura. O baixo rendimento econômico auferido pelos coletores de frutos do cupuaçuzeiro nativo, em função da oferta de frutos promovida pelas lavouras, ocasionou desestímulo e uma tendência irreversível de migração dessa atividade para o plantio racional (Homma et al., 2001). Tal fato fragiliza ainda mais a manutenção das populações naturais, pois os interessados mais imediatos na manutenção das plantas no ambiente silvestre, passarão a não mais existir.

A transição de uma atividade eminentemente extrativa, para o agro-cultivo teve um impacto ambiental menos drástico que em outros cultivos. Isto porque, não obstante a franca expansão da área cultivada, a cultura vem sendo instalada em áreas anteriormente ocupadas com outras espécies, que tiveram problemas de mercado ou fitossanitários, sendo algumas utilizadas como sombreamento provisório ou definitivo. Isto dispensou, em algumas áreas, a necessidade de derruba e queima da mata, prática rotineira na região, com redução dos custos iniciais de implantação. Grandes extensões de terras ocupadas por capoeiras improdutivas, poderiam ser recuperadas e valorizadas pelo plantio do cupuaçuzeiro em trilhas, novamente com baixo impacto ambiental. Além do mais, as próprias características ecológicas da lavoura, favorecem a manutenção do ecossistema. A boa aceitação do cupuaçuzeiro como cultivo deve-se também ao fato de ser uma espécie muito apropriada à sistemas agroflorestais, consorciando-se favoravelmente com várias outras culturas (Venturieri, 1993).

A comercialização dos frutos é realizada em feiras e supermercados, entretanto uma vasta rede de microempresários podem ser encontrada nas grandes e médias cidades da região amazônica, que promove a transformação da polpa principalmente em bombons, balas e biscoitos. Contudo o sorvete parece ser a forma mais ativa de aproveitamento industrial, visto que, na Amazônia praticamente todas as sorveterias oferecem o produto. Industrias de doces e compotas instalaram-se em Belém e Manaus, porém o mercado regional ainda é o preferencial. Atualmente suco e polpa congelada podem ser encontradas em quase todos os mercados do país, beneficiadas por médias e grandes empresas. A utilização de sementes de cupuaçu como um sucedâneo para o cacau, ainda não tornou-se realidade, em razão dos baixos preços obtidos pelo cacau, além de carência de pesquisas tecnológicas para disponibilizar um produto mais bem acabado. A utilização da gordura de sementes de 
cupuaçu parece ter mais chances, a curto prazo, na indústria de cosméticos, onde alguns produtos estão sendo ofertados ao mercado. Contudo, apesar do mercado nacional estar paulatinamente absorvendo produtos oriundos do cupuaçu, o mercado internacional somente será conquistado se forem equacionados dois entraves básicos: garantia de oferta regular da matéria prima nas quantidades requeridas e qualidade compatível com os altos padrões exigidos pelo mercado internacional. Para tanto, técnicas adequadas de processamento e envazamento devem ser desenvolvidas, dentro das especificações de cada mercado (Calzavara et 1984; Venturieri, 1993).

A análise de comercialização do cupuaçu na Amazonia brasileira tem demonstrado que o produtor recebe pelo fruto vendido apenas 34,4 a $41,2 \%$ do preço pago pelo consumidor final e, pela polpa congelada, somente $26,6 \%$ (Rodrigues \& Santana, 1997). Em razão da pequena margem de lucro, os produtores têm procurado agregar valor ao produto, processando e comercializando a produção diretamente em restaurantes, supermercados, bares entre outros (Carvalho et al., 1999).

\subsubsection{Origem e distribuição geográfica}

O conhecimento da origem e dispersão das espécies do gênero Theobroma é baseado em levantamentos feitos em herbários e relatos de expedições botânicas (Cuatrecasas, 1964). A distribuição geográfica do cupuaçuzeiro originalmente restringia-se às áreas de floresta nativa ao sul do rio Amazonas, oeste do rio Tapajós, incluindo o sul e sudeste do Estado do Pará e a região "pré-amazônica" do estado do Maranhão (Ducke, 1946). Esta região foi considerada por Cuatrecasas (1964) como o centro de origem da espécie. Trata-se de uma espécie pré-colombiana que, possivelmente, foi disseminada, de seu centro de origem, para todos os estados da região Norte, através da intensa movimentação das nações indígenas no interior da Amazônia (Clement, 1999; Cavalcante 1991).

Saber atualmente se uma população é expontânea ou sub-expontânea não é tarefa fácil. A densidade das plantas pode ser um indicativo do tipo de ocorrência. As árvores, em sua área de ocorrência natural, a exemplo da maioria das espécies arbóreas amazônicas, são encontradas em baixa densidade. Homma et al. (2001) estimaram que a densidade do cupuaçuzeiro na região de Marabá, onde a 
concentração de cupuaçuzeiro é relativamente alta, era de duas árvores por hectare, podendo chegar até 3,75 plantas por hectare.

Atualmente essa fruteira esta sendo cultivada, em pequena escala, em vários

estados brasileiros, como Bahia, S. Paulo, Paraná entre outros, já tendo sido levado para outros países como Guiana, Martinica, Equador, São Tomé, Trinidad, Gana e Costa Rica (Venturieri e Aguiar, 1988).

\subsubsection{Aspectos taxonômicos e botânicos}

O cupuaçuzeiro que pertencia a família Sterculiaceae, atualmente esta classificado dentro da família Malvaceae (Alverson et al., 1999). O gênero Theobroma, tipicamente neotropical, contém 22 espécies, e encontra-se distribuído nas florestas tropicais úmidas do hemisfério ocidental, entre as latitudes $18^{\circ}$ Norte e $15^{\circ}$ Sul, estendendo-se do México ao Sul da floresta amazônica. Segundo Cuatrecasas (1964) este gênero é composto por seis seções: Andropetalum, Glossopetalum, Oreanthes, Rhytidocarpus, Telmatocarpus e Theobroma. Todas essas seções ocorrem na Amazônia, exceto a seção Andropetalum encontrada apenas na Costa Rica. O cupuaçuzeiro está enquadrado na seção Glossopetalum, a qual engloba 12 das 22 espécies do gênero (Cuatrecasas, 1964).

A espécie T. grandiflorum é diplóide e apresenta $2 n=20$ cromossomos (Carletto, 1946), sendo que Moraes et al. (1994) reporta que o cupuaçuzeiro sem sementes (mamau) coletado no município de Cametá, Estado do Pará, é triplóide com 30 cromossomos, possivelmente decorrente de mutação natural. Esse clone apesar do elevado rendimento de polpa, superior a $60 \%$, apresenta como desvantagem a susceptibilidade à vassoura-de-bruxa e baixa produtividade (Müller \& Carvalho, 1997). Outra matriz cujos frutos apresentavam número reduzido de sementes foi coletada em Manacapurú, estado do Amazonas (Lima \& Costa 1991), porém não é conhecido ainda o nível de ploidia. Segundo Moraes et al. (1994), a descoberta na natureza de indivíduos triplóides viáveis, abre a possibilidade de obtenção de triplóides artificiais, com grande interesse mercadológico, através de cruzamento entre diplóides e tetraplóides estes últimos obtidos por intermédio de indivíduos diplóides, que teriam o número de cromossomo duplicados através de agentes mutagênicos. 
O cupuaçuzeiro é uma árvore que, em condições naturais, é retilínea podendo atingir mais de $30 \mathrm{~m}$ de altura e perímetro de tronco superior a $100 \mathrm{~cm}$. Nas áreas cultivadas sua altura varia de 6 a $10 \mathrm{~m}$, porém parte dos agricultores efetua a poda após o segundo fluxo de lançamentos, para forçar a emissão de ramos secundários e, com isso reduzir a altura da planta. Apresenta copa de formato variável, normalmente irregular e pouco espessa, com tronco de coloração acinzentada com manchas brancas. As folhas são simples, alternas, curto pecioladas, com lâmina verde mais ou menos brilhante, glabra, na face superior e ferrugíneo-tomentosa na face inferior. As inflorescências são cimulosas, axilares ou ramifloras com três a cinco flores. As flores são hermafroditas, actinomorfas, heteroclamídeas e hipógenas, com cinco sépalas espessas, triangulares, livres ou parcialmente unidas no terço inferior; cinco pétalas carnosas, com base arredondada-cuculadas e lâmina unguiculada subtrapezoidal de coloração que varia do branco ao vermelho-violeta, ligada à cógula por uma porção estreita em forma de calha; cinco estaminóides estéreis petalóides, triangularlingüiformes, vermelho-escuros, independente da cor das pétalas; androceu com dois verticilios de estames localizados no interior da cógula; ovário súpero, pentalocular, cada lóculo contém cerca de 10 óvulos. Os óvulos são anátropos e o estilete filiforme. O fruto é uma baga drupácea oblonga, elipsóide ou oboval, com as extremidades obtusas ou arredondadas, que cai da árvore quando maduro, após quatro a quatro meses e meio desde a polinização (Prance \& Silva, 1975; Calzavara et al., 1984; Cavalcante, 1991). O epicarpo é lenhoso recoberto de pelos ferrugíneos que, quando raspado expõe uma camada clorofilada. O mesocarpo é esponjoso e pouco resistente. O endocarpo (parte comestível) tem coloração branco-amarelada, de sabor ácido e odor agradável, e recobre as sementes. Estas apresentam-se em número variável de 15 a 50, em média 36 por fruto, com 2,5 cm de largura e 0,9 cm de espessura. Apresentam-se superpostas em torno da placenta e longitudinalmente dispostas em relação ao comprimento do fruto (Calzavara et al., 1984; Venturieri, 1993; Souza et al., 1996b).

Os frutos apresentam características físicas e químicas bastantes variáveis. Ribeiro et al. (1992) encontraram uma variação para peso de fruto entre 878 e $1.665 \mathrm{~g}$, enquanto rendimento de polpa variou de 24 a 44\%. Os caracteres percentagem de sementes e percentagem de polpa mostraram ser os menos influenciados pelo 
ambiente (Fonseca et al., 1990). Os valores médios de Brix $(10,9)$ foram inferiores aos obtidos por Alves et al. (1998b) nas condições amazônicas $(13,4)$, porém os valores de $\mathrm{pH}$ foram muito similares em torno de 3,3. Ribeiro et al. (1992) observaram também elevado teor de vitamina C $(23,6 \mathrm{mg} / 100 \mathrm{~g})$, pectina $(0,39 \%)$ e proteína $(8,1 \%)$ e traços de diversos minerais, que tornam o cupuaçuzeiro relativamente superior à maioria das outras fruteiras amazônicas. A acidez natural e a pectina favorecem a fabricação de néctares, geléias e outros doces pastosos. Essa acidez é suficiente para manter a qualidade do néctar durante o armazenamento (Barbosa et al., 1978; Chaar, 1980). Além do mais, nas sementes foram encontrados altos índices de gordura (61\%) e de proteína (24,2\%). Venturieri (1993) e Carvalho et al. (1999) relatam estudos comparativos entre diferentes autores que realçam a diversidade dos resultados disponíveis, decorrentes de características intrínsecas dos materiais e da falta de padronização das metodologias de avaliação e análise.

O cupuaçuzeiro é uma fruteira precoce, com a produção de frutos tendo início no terceiro ano. Entretanto, a produção é bastante irregular, com grande variação entre plantas, sendo, também, muito afetada pelas condições ambientais. Falcão e Lleras (1983) observaram que o cupuaçuzeiro apresenta baixa fecundidade, pois para produzir 17 frutos/planta são necessárias 3.500 flores. Um dos fatores que pode influenciar nessa taxa de vingamento de frutos é a baixa atividade dos polinizadores (Venturieri, 1993).

A produção média de cupuaçuzeiros nativos é de 25 frutos/pé. Nas áreas nativas, entretanto, estima-se uma perda de $10 \%$ decorrente da rachadura dos frutos provocada pela queda da árvore e, pela presença de animais selvagens como macacos, que derrubam flores e frutos imaturos, e roedores que se alimentam de frutos caídos ao solo (Homma et al., 2001). Em condições de cultivo a variação de produção entre plantas é bastante pronunciada, devido a desuniformidade do material de plantação, além de variações nas condições climáticas e de cultivo. Estima-se em 12 frutos/árvore a produtividade média dos cultivos no quinto ano, estabilizando em torno de 20 frutos/árvore (Calzavara et al., 1984). Contudo, não são observadas as perdas reportadas para as condições silvestres, devido ao porte baixo das árvores e a colheita sistemática dos frutos. Entretanto, secas prolongadas e ataques da doença 
vassoura-de-bruxa, cujo agente etiológico é o fungo Crinipellis perniciosa, respondem por mais de $20 \%$ das perdas de safra.

Frutos maduros são facilmente reconhecidos em razão do cheiro agradável que exalam (Souza et al., 1996b). Frutos após caírem ao solo (normalmente à noite) devem ser imediatamente colhidos, e se mantidos a temperatura ambiente, conservam boas características organolépticas por cinco dias. A polpa pode ser mantida congelada por sete meses sem perda de qualidade (Miranda, 1989).

\subsubsection{Ecologia das populações}

O cupuaçuzeiro ocorre em solos de terra firme e várzea alta, ocupando o estrato de sub-dossel da floresta. Foi encontrado também em condições de baixios, associado ao açaizeiro.

O clima nas áreas de ocorrência natural do cupuaçuzeiro é quente e úmido, com temperatura média anual variando de $21,6{ }^{\circ} \mathrm{C}$ a $27,5^{\circ} \mathrm{C}$; umidade relativa média anual de $77 \%$ a $88 \%$ e pluviosidade media anual que varia de $1.900 \mathrm{~mm}$ a $3.100 \mathrm{~mm}$ (Diniz et al., 1984).

Entretanto, o cultivo tem se estendido à diferentes tipos de solo e climas, o que muitas vezes contribuí para dificuldades de implantação, podendo até mesmo inviabilizá-la, com perdas de mudas que desfalcarão os talhões. Alves et al. (1999c) reportam uma metodologia para contornar os problemas de implantação de cultivos em áreas com distribuição irregular de chuvas. Consiste, basicamente, no uso de materiais de plantação selecionados no próprio local e, portanto, já adaptadas a essas condições, e o emprego de linhas de plantio dentro de capoeiras (sistema cabruco). Apesar de divergências iniciais, hoje há consenso de que o cupuaçuzeiro para produzir na capacidade máxima, necessita de sombreamento parcial na fase inicial de estabelecimento de campo (Moraes et al., 1994). Contudo, esse sombreamento deve ir sendo paulatinamente retirado até ser praticamente eliminado após a estabilização da produção (em torno do 10 ano). Entretanto a utilização desse sistema de condução oferece riscos em plantações estabelecidas em locais com prolongados períodos de déficit hídrico. Pois assim que as chuvas voltam, ou quando são realizadas irrigações muito abundantes, ocorre uma rápida absorção de água, provocando um aumento da 
pressão interna do fruto e, como a casca não é elástica, provoca rachaduras favorecendo a penetração de fungos saprofíticos. A utilização de cobertura morta ou irrigações suplementares durante esse período, constituem formas de minimizar o problema (Carvalho et al., 1999).

\subsubsection{Sistema de reprodução}

Entre os fatores mais importantes na determinação da variação existente entre espécies em relação a estrutura genética, destaca-se o sistema reprodutivo, pois este afeta a estrutura e dinâmica das populações naturais (Brown, 1978; Ritland e Jain, 1981). Assim sua caracterização e a estimativa da taxa de cruzamento, são importantes para o estudo da dinâmica dos alelos, em populações naturais e artificiais, tanto em programas de melhoramento, quanto para definição de estratégias de manejo e conservação.

Taxa de cruzamentos superiores a $60 \%$ foram obtidos em muitas espécies tropicais utilizando estimativas multilocos como em Cedrella fissilis (Gandara, 1996), Bertholletia excelsa (O'malley et al., 1988), Carapa guianensis (Hall et al., 1994), entre outras, e valores intermediários em pouca espécies como Hevea brasiliensis (Paiva et al., 1994a), Ceiba pentandra (Murawsky e Hamrick, 1992a), Cavanillesia platanifolia (Murawsky et al., 1990), entre outras, porém nestas últimas os autores estimaram apenas a taxa de cruzamento aparente que produz valores subestimados por não considerar as combinações genotípicas em todos os locos dos indivíduos.

O cupuaçuzeiro é tido como uma espécie alógama, auto-incompatível, com flores hermafroditas, cuja fecundação ocorre, além do estigma, ao longo do estilete, semelhante ao milho. Na região amazônica, floresce no período de julho a dezembro, período mais seco do ano, e frutifica de agosto a abril (Prance \& Silva, 1975), sendo que o pico de frutificação acontece no primeiro trimestre do ano, período das chuvas. Portanto, a espécie guarda uma forte interação com o ambiente, pois é no período seco que a atividade dos insetos polinizadores é mais intensa, enquanto que, no período das chuvas ocorre maior demanda fisiológica por água, para desenvolvimento e maturação dos frutos. Contudo, nas áreas cultivadas onde são utilizadas irrigação, 
adubação balanceada e material de plantação heterogêneo, o ciclo produtivo torna-se praticamente contínuo, com períodos muito curtos de entre-safra.

As flores apresentam barreiras físicas que isolam o estigma das anteras, além de um complexo sistema de auto-incompatibilidade que torna a espécie obrigatoriamente alógama (Venturieri, 1993; Venturieri \& Ribeiro Filho, 1995). Sistemas de auto-incompatibilidade parecem ser comuns dentro do gênero Theobroma, sendo que, foram bastante estudados em T. cacao (Pound, 1932; Marshall, 1933; Cope, 1938 e 1962; Knight \& Rogers, 1955; Yamada et al, 1982). À semelhança do cacaueiro, o cupuaçuzeiro apresenta auto-incompatibilidade com reação tardia no ovário, prézigótica, ocorrendo abscisão da flor antes da formação do embrião (Venturieri, 1994).

São visitadas por muitas espécies de insetos como abelhas e formigas que tem tornado difícil distinguir entre polinizadores, predadores e pilhadores de pólen. Falcão \& Lleras (1983) concluíram que, para a região de Manaus - AM, não havia um polinizador específico e sim várias espécies de abelhas deveriam ser as responsáveis pela polinização. Venturieri (1993) reportou que as abelhas sem ferrão Plebeia minima, Trigonisca sp. e Ptilotrigona lurida, seriam os prováveis polinizadores. Venturieri et al. (1997) concluíram que sete espécies de besouros (família Chrysomelidae: subfamília Eumolpinae) deveriam ser consideradas os polinizadores efetivos do cupuaçuzeiro. Visto que as flores não apresentam nectários, acredita-se que a presença abundante de pólen e exalação de odor sejam os componentes utilizados para atrair os insetos polinizadores (Neves et al., 1993; Venturieri, 1994).

A deiscência das anteras ocorre simultâneamente com a receptividade do estigma, pouco antes da abertura total das flores, sendo que, a maior taxa de antese ocorre entre as 16 e 18 hs (Venturieri, 1994).

\subsubsection{Agentes naturais de dispersão}

Através de observações de campo foi verificado que a dispersão da espécie é efetuada prioritariamente por zoocoria, através de macacos (Cebus apella) que quebram os frutos nos galhos para retirar a polpa com as sementes, e roedores como cotias (Dasyprocta spp.) que escondem/enterram algumas sementes, além de outros animais como pacas (Agouti paca) que apesar de se alimentar dos frutos 
aparentemente não "estocam" sementes (Smith et al., 1992; Homma et al., 2001). Porém, a própria altura das árvores, muitas vezes superior a $30 \mathrm{~m}$, facilita a dispersão das sementes por autocoria, pois um percentual significativo de frutos quando caem ao solo se rompem, liberando as sementes. Entretanto, normalmente não são observadas plântulas na circunvizinhança da planta matriz, possivelmente porque o ataque de predadores é mais intenso nessa região. fruto rachado, por outro lado, é um dos fatores que contribuem para o baixo rendimento econômico do extrativismo de frutos dessa espécie.

Contudo, conforme reportado por Clement (1999) o grande agende dispersor da espécie tem sido o próprio homem, pois devido ser uma das fruteiras preferidas pelos índios, foi sempre levada de uma aldeia a outra, sendo assim disseminada para todos os estados da região Norte. Devido ao intenso movimento das nações indígenas o cupuaçuzeiro foi levado ao longo da calha do rio Amazonas e seus tributários, chegando a países limítrofes do Brasil como Peru e Colombia (Smith et al., 1992).

\subsubsection{Conservação das populações}

A conservação dos ecossistemas tropicais e portanto de sua diversidade, definida como a riqueza de espécies e a variabilidade genética dentro de cada espécie, somente será efetiva quando essa conservação estiver acoplada a alternativas para obtenção de renda pelos proprietários da terra (Reis, 1996). Para gerar esses mecanismo e melhorar o manejo das populações naturais, há necessidade de conhecer os processos que contribuem para a sustentabilidade biológica da espécie. Para coleções de germoplasma altamente estruturadas têm sido mostrado que marcadores moleculares podem ser úteis para otimizar estratégias de amostragens, em face dos limitados recursos para conserva-las.

A Amazônia é um dos principais centros de diversidade de fruteiras domesticadas do mundo. Segundo Clement (1997), pelo menos 40 espécies de fruteiras nativas da Amazônia foram domesticadas pelos silvícolas antes da chegada dos portugueses, assim como outras 40 fruteiras foram introduzidas do Nordeste brasileiro e de outros países americanos antes do contato, contribuindo para a riqueza de espécies hoje existente. Porém, fatores como a aculturação dos povos indígenas, o 
êxodo rural dos cablocos, a imigração de povos extra-regionais e a expansão da fronteira agrícola, têm contribuído para que parte dessa diversidade esteja sendo perdida (Clement, 1997).

Em cada população podem ser observadas características agronômicas específicas, relacionadas com o tamanho e forma do fruto, espessura da casca entre outros. Por exemplo nas populações de cupuaçuzeiro do rio Anapú alto predominam frutos com peso superior a 3,0 kg (Villachica, et al., 1996).

Por apresentar semente recalcitrante o cupuaçuzeiro não pode ser conservado em câmara frigorífica, que implicaria em custos de manutenção mais reduzidos. Conservação in vitro e criopreservação que seriam outras tecnologias viáveis, ainda não estão disponíveis, por carência de protocolos adequados tanto para micropropagação quanto regeneração de sementes ou embriões criopreservados.

Portanto, as únicas alternativas disponíveis à curto prazo, são a conservação in situ e ex situ, esta na forma de coleções vivas no campo, que irão constituir o Banco Ativo de Germoplasma. Dentre essas, a conservação in situ é a mais adequada, por manter a espécie no seu ambiente natural permitindo a continuidade dos processos evolutivos. Por outro lado quando a conservação in situ é impraticável a conservação ex situ deve ser implementada (Dias \& Kageyama, 1991). Vale ressaltar que regra geral estas duas modalidades são complementares e não excludentes (Griffith, 1987).

No caso da conservação in situ a análise por marcadores genéticos é vantajosa, pelo menor tempo e custo de avaliação. Contudo, quando se trata de conservação ex situ, os ensaios de campo passam a ter maior valor, dado que permitem a avaliação da capacidade adaptativa e produtiva das espécies. Sempre que possível o ideal portanto, é combinar estudos de marcadores genéticos, caracteres morfológicos e fisiológicos que descrevam a variação genética entre e dentro de populações naturais de plantas, para montar estratégias adequadas de conservação genética (Hamrick, 1983).

Para implementar as estratégias de conservação in situ, há necessidade de conhecer a biologia reprodutiva, ecologia e padrão de distribuição das espécies 
envolvidas, cujas informações possibilitarão estabelecer o tamanho e a configuração das reservas florestais (Griffith, 1987).

Dentro desse contexto, a medida do tamanho efetivo populacional é de fundamental importância para a conservação genética. Normalmente essa medida é inferior ao número de plantas amostradas, motivado pelo nível de endogamia e parentesco existente na amostra, sendo que, quanto maiores esses níveis, menor será a representatividade genética da amostra (Vencovsky, 1987). Na conservação in situ, o tamanho efetivo serve para delimitar a área mínima viável para a conservação de uma espécie (Sebbenn, 1997). Segundo Frankel \& Soulé (1981) para conservação a curto e médio prazo um $N_{e}$ igual a 50 é suficiente para prevenir a perda de alelos raros, enquanto que 500 deve ser o tamanho efetivo para a conservação de alelos raros a longo prazo.

\subsubsection{Conservação in situ}

Neste tipo de conservação os processos evolutivos têm prosseguimento normal, tornando-se a alternativa mais viável para conservação de uma espécie perene florestal (Figura 3).

Como o cupuaçuzeiro nativo tem uma ocorrência restrita, que coincide com uma das regiões de maior pressão antrópica do país, há necessidade, preliminarmente, de definição das áreas mais representativas da variabilidade da espécie, para serem transformadas em reservas legais. Para identificar essas populações, foi iniciado um projeto em 2001, no qual estão sendo feito estudos sobre a estrutura e variabilidade genética entre e dentro das populações silvestres de T. grandiflorum no centro de máxima diversidade. Definidas as populações, deverão ser iniciados estudos mais aprofundados sobre os mecanismos mantenedores da variabilidade genética e, responsáveis pela perpetuação da espécie, como o fluxo gênico, definição de polinizadores e dispersores de sementes entre outros, que permitirão, além da conservação, um manejo sustentável desses recursos, especialmente com fins de direcionamento de coletas e aproveitamento de acessos 

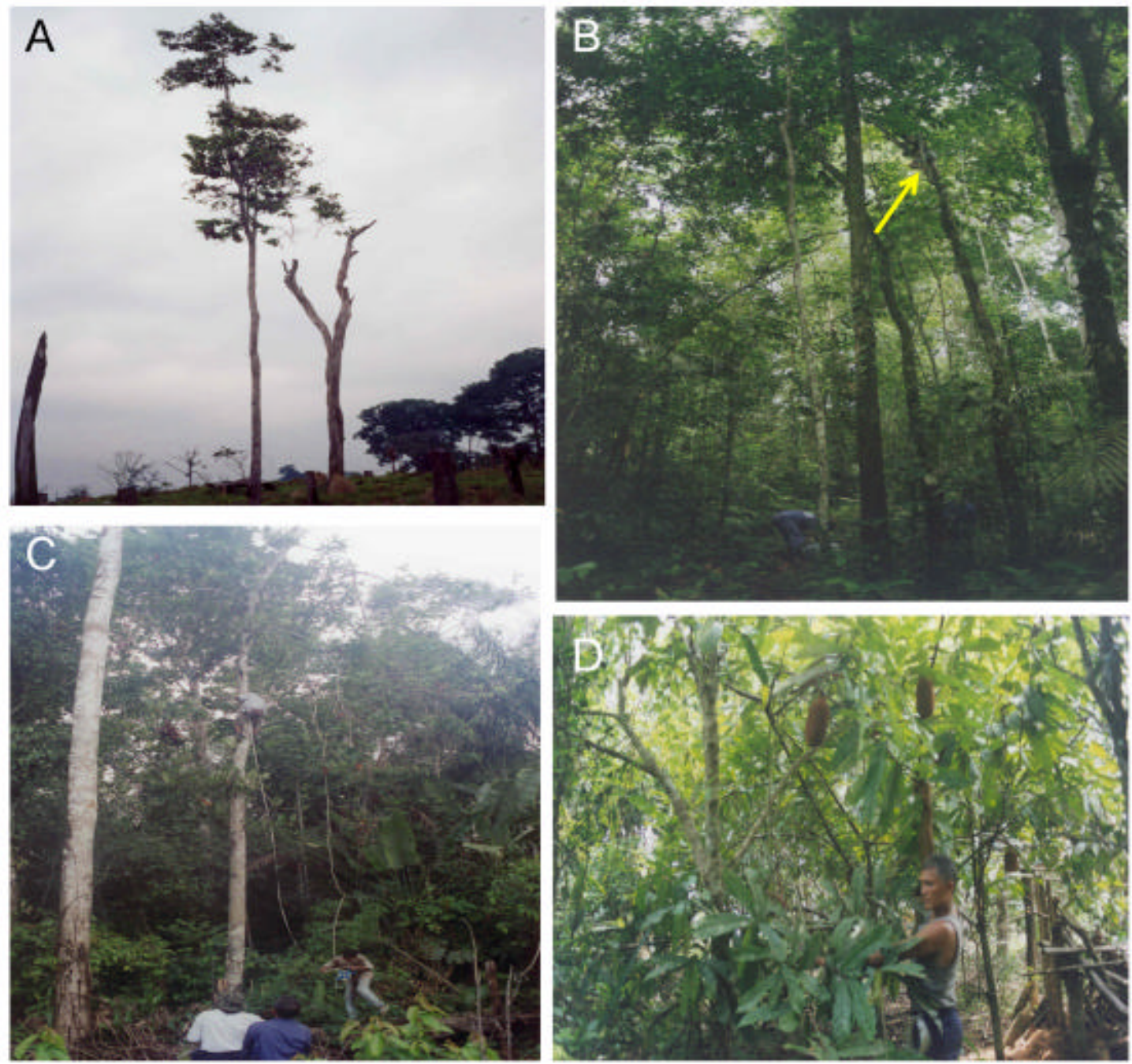

Figura 3 - Árvores de cupuaçuzeiro em ambiente nativo (A, B e C) e cultivado (D). 
diretamente para o programa de melhoramento genético (Alves \& Figueira, 2002). Outra vantagem da conservação in situ refere-se aos custos de manutenção, infinitamente menores em relação à conservação ex situ. A grande dificuldade é conseguir a transformação dessas populações nativas em reservas legais e, que seus limites sejam permanentemente respeitados.

\subsubsection{Conservação ex situ}

A formação de coleções ex situ tem sido a primeira etapa para dar suporte a um programa de melhoramento. Quase todas as instituições de pesquisa do norte do Brasil mantêm sua coleção de cupuaçuzeiro, com essa finalidade. Pesquisas desenvolvidas nessas coleções permitiram romper o ciclo de extrativismo e cultura de fundo de quintal à que a espécie estava submetida (Müller \& Carvalho, 1997).

Porém, acredita-se que a variabilidade genética conservada nessas coleções ainda esta muito longe de contemplar uma amostragem significativa da existente na espécie. Coletas em áreas de forte pressão antrópica, que oferecem risco iminente, deverão ser empreendidas imediatamente. No Pará, o sul e Sudeste do estado, especialmente a microregião de Marabá, enquadram-se dentro dessa categoria e, portanto, merecem ser priorizados (Alves et al., 1996).

A falta de metodologias adequadas para conservação das coleções à campo, o custo oneroso de manutenção, a carência de material humano capacitado para maneja-las, aliado às frustações de experiências anteriores com outras espécies amazônicas, principalmente decorrentes de condicionantes bióticos, têm servido como desestímulo para novas coletas de germoplasma na região. Porém, apesar desses problemas as coleções à campo, tem a vantagem de permitir a caracterização e avaliação dos acessos, o que facilita a conservação e utilização pelo programa de melhoramento, que normalmente estão acoplados ao programa de recursos genéticos.

No intuito de minimizar a ocorrência do ataque de pragas e doenças nas coleções de germoplasma, Paiva (1994b) propõe um novo modelo de conservação de espécies perenes amazônicas, que combina diversidade, densidade e variabilidade genética. Dentro desse modelo os acessos de cupuaçuzeiro, atualmente conservados em coleções uniespecífica, comporiam coleções poliespecíficas que tentariam imitar as 
condições ecológicas do habitat silvestre e, assim, torna-las menos vulneráveis, principalmente, ao ataque de patógenos como a vassoura-de-bruxa, para serem devidamente avaliadas e utilizadas.

Esse modelo segue a mesma linha básica da proposta de Dantas (1986) para a implantação de cultivos na Amazônia. Este autor observou que, a utilização de policultivos era uma alternativa mais viável para o estabelecimento de plantios racionais com espécies perenes na Amazônia, pois a incidência de pragas e doenças era sempre menor que nos monocultivos. Tais sistemas propiciam condições ecológicas que tentam imitar a floresta, garantindo sustentabilidade biológica, com maiores possibilidades, portanto, de sucesso.

Porém, o que tem sido observado nas regiões produtoras, principalmente entre alguns produtores de médio e grande porte, é a utilização de consórcios do cupuaçuzeiro com maracujá, mamão, pimenta do reino ou banana, entre outros, apenas na fase juvenil. Terminada essa fase, a lavoura passa a ficar solteira. A utilização de policultivos tem sido mais empregada pelos pequenos produtores, que já possuem vasta experiência adquirida na formação de pomares caseiros (quintais). Os sistemas agroflorestais, por levarem em conta os aspectos econômicos, sociais e ambientais, são alternativas inegáveis de vocação para a sustentabilidade (Souza \& Souza, 1999).

\subsection{Formação de Banco Ativo de Germoplasma (BAG)}

O termo germoplasma é originário das expressões "plasma" ou matéria primordial dos seres vivos e "germinal", referente as células germinativas, capazes de gerar novas células por simples divisão ou por união com outros elementos germinais (Pereira, 1989).

Germoplasma é definido por Allard (1971) como sendo a soma total dos materiais de uma espécie. Assim, estes poderão ser na forma de plantas, anteras, pólen, sementes, tecidos (meristema, calo), células ou estruturas ainda mais simples.

Como atividades do BAG existe a coleta de materiais silvestre e cultivado, a caracterização e avaliação dos acessos, além de promover a introdução e intercâmbio 
desses recursos. Visa assegurar que o máximo de diversidade genética seja preservada e utilizada de forma racional (Figueira e Cascardo, 2001).

Nos programas de recursos genéticos e melhoramento do cupuaçuzeiro os BAG's desempenham um papel de extrema importância, uma vez que são os depositários da variabilidade genética à disposição do melhorista. Os genótipos selecionados podem ser utilizados de forma direta, como variedades comerciais, ou empregados nos programas de melhoramento, visando a criação de novas cultivares. Desta forma, os acessos nos BAG's precisam estar caracterizados e avaliados para facilitar, além das ações de recurso genético, o trabalho dos melhoristas na seleção dos materiais a serem utilizados.

Para dar suporte técnico à cultura do cupuaçuzeiro, foi estabelecido pela Embrapa Amazônia Oriental, um programa de recursos genético e melhoramento, que objetivou, basicamente, a formação de coleções constituídas por genótipos coletados em condições silvestres e em plantios comerciais (Pimentel \& Alves, 1995). A caracterização dessas coleções, tanto do ponto de vista morfológico como molecular, é um passo fundamental para o embasamento científico do programa, que deverá ser acompanhado pela avaliação e seleção de cultivares (Alves \& Figueira, 2002).

As expedições tiveram início no período de 1984 à 1988, relatadas por Lima et al. (1986) e Lima \& Costa, (1991 e 1997). Como produto dessas campanhas foi constituída uma coleção formada por 46 acessos coletados em vários estados da Amazônia brasileira.

Nessas expedições foram encontradas matrizes que possuíam características agronômicas interessantes como frutos que apresentavam em média $36,0 \mathrm{~cm}$ de comprimento. Outras matrizes encontravam-se inteiramente livres da doença vassourade-bruxa, apesar das plantas circunvizinhas estarem altamente infestadas por essa doença. Foram encontradas, também, uma matriz que apresentava número reduzido de sementes nos frutos e outra cujos frutos pesavam mais de 6,0 kg (Lima \& Costa, 1997), dentre inúmeras outras variações que servem para exemplificar o grau de variabilidade desses acessos. Contudo, nas condições nativas, em razão da dispersão promovida pelas outras espécies, numa matriz, aparentemente livre de doença, é mais 
provável que esteja acontecendo escape do que propriamente resistência genética à doença.

Atualmente o Banco Ativo de Germoplasma de cupuaçuzeiro é constituído por pequenas coleções instaladas nos institutos de pesquisa da região Norte. São constituídas por clones e progênies maternas de polinização livre, que foram estabelecidas em Belém - PA, Manaus - AM, Porto Velho - RO e Rio Branco - AC. Os acessos foram coletados em áreas de ocorrência natural, plantios comerciais e pomares caseiros (Moraes et al., 1994).

Uma dessas coleções, constituída por 128 clones e 119 progênies maternas de polinização livre, coletados no Alto Solimões (AM), Médio Amazonas (AM) e região Bragantina (PA), encontra-se conservada na Embrapa Amazônia Ocidental, localizada em Manaus, AM (Souza, 1997).

Ainda em Manaus, encontra-se a coleção instalada pelo INPA, composta por 132 acessos coletados em Tucuruí - PA, no local que foi inundado para formação do lago, formado pela barragem da hidrelétrica local, e na região da pré - Amazônia Maranhense.

Em Belém - PA na Embrapa Amazônia Oriental, estão sendo conservados 46 clones de cupuaçuzeiro coletados nos estados do Pará, Amazonas e Amapá. Completam esta coleção 50 clones e 49 progênies maternas de polinização livre de cupuaçuzeiro coletados em plantios comerciais do estado do Pará e instalados no município de Tomé açu - PA (Alves, 1997c) e 34 clones selecionados no município de Belterra - PA e instalados no Campo experimental da EMBRAPA, na sede do município(Alves et al., 1999c).

Em Rondônia os trabalhos de pesquisa para formação de uma coleção foram iniciados em 1992 pela Embrapa Rondônia, sendo que foram prospectadas e identificadas 64 matrizes promissoras em vários municípios daquele estado, das quais 36 encontram-se instaladas à campo, na forma de progênies (Ribeiro, 1997). 
Idêntico trabalho teve início no Acre em 1992, quando foram realizadas coletas em plantações comerciais de vários municípios do estado, sendo introduzidas 12 matrizes promissoras na coleção da Embrapa - Acre (Cavalcante \& Costa, 1997).

\subsection{Avaliação e caracterização botânico-agronômica}

A variabilidade existente nas coleções de campo somente será aproveitável no programa de melhoramento, caso seja identificada e esquematizada. Esse conhecimento é obtido através da caracterização dos acessos, quando são reveladas as características intrínsecas de cada material. Uma amostra da variabilidade fenotípica que ocorre entre acessos dentro das coleções, pode ser visualizada nas Figuras 2.

Os conhecimentos disponíveis até o momento dizem respeito à caracterização morfológica foliar (Alves et al. 1997b), floral (Alves et al. 1998a), de fruto (Alves et al., 1996; Souza et al., 1996a; Araújo et al., 2002). e bromatológica (Alves et al., 1998b).

Avaliações quanto a capacidade de produção de frutos (Alves et al., 1997c; Souza \& Silva, 1997, Cruz \& Alves, 2001), resistência genética à vassoura-de-bruxa (Alves et al., 1998c e 1998e; Bastos et al., 1999; Cruz et al., 2000) e fenologia (Araujo \& Alves, 1995; Alves et al., 1997c), são rotineiramente empregadas nas diferentes coleções de cupuaçuzeiro.

Dentre os problemas enfrentados para tornar o cupuaçuzeiro um cultivo sustentável destaca-se a doença conhecida como vassoura-de-bruxa, causada pelo fungo Crinipellis perniciosa, (Stahel) Singer, que vem acarretando danos econômicos significativos nas plantações, obrigando produtores das áreas tradicionais a abandonar seus cultivos, tendo-se tornado um dos fatores limitantes à expansão da lavoura (Alves et al., 1998e). Tentativas de controle da doença como poda fitossanitária, que consiste na remoção de ramos e frutos afetados pela doença, não têm promovido redução no índice de doenças nas plantações (Yoneyama et al., 1997). Porém, Falcão et al. (1999) observaram aumento na percentagem de vingamento de frutos, como reflexo da eficácia da poda fitossanitária. A utilização de fungicidas ainda é muito pouco utilizada, em razão da carência de pesquisas específicas para definir a relação custo benefício (Yoneyama et. al., 1997). 
A utilização de cultivares resistentes aliada ao emprego de técnicas que minimizem a propagação de epidemias como adubação balanceada, plantio multiespecíficos, nível de sombreamento equilibrado, podas profiláticas, uso de fungicidas eficientes entre outras, são estratégias que certamente promoverão uma melhor sanidade e, conseqüentemente, maior produtividade às lavouras (Alves et al., 1998a; Cruz et al., 2000; Cruz \& Alves, 2001). Alguns trabalhos nestas linhas de pesquisa já foram iniciados pela Embrapa Amazônia Oriental.

A primeira tentativa para obter materiais resistentes teve início em 1986, com a coleta de acessos aparentemente resistentes à enfermidade e formação do BAG de cupuaçuzeiro (Lima \& Costa, 1991). Pelo fato das avaliações terem sido feitas à campo, a identificação dos materiais resistentes consumiu um longo período de tempo, atrasando o fluxo de melhoramento. Para tentar agilizar o processo de seleção de cultivares resistentes, métodos bioquímicos e moleculares estão sendo propostos. Bastos et al., (1999) reportam uma metodologia utilizada para avaliar resistência à vassoura-de-bruxa do cacaueiro, baseada na seiva, que foi adaptada para utilização no cupuaçuzeiro. Foi empregada em alguns acessos do BAG de cupuaçuzeiro - Belém, para comparar a incidência de vassoura-de-bruxa no campo, com bioensaios in vitro. Os resultados demonstraram que era possível ter um indicativo preliminar de quais são as plantas resistentes/tolerantes e susceptíveis à $C$. perniciosa, em um período de tempo muito mais curto que o procedimento tradicional. Apesar de não oferecer uma solução completa para investigar a resistência do cupuaçuzeiro à vassoura-de-bruxa, os autores concluíram que a metodologia poderia ser usada, juntamente com outros fatores, na avaliação de materiais promissores.

A metodologia de mapeamento dos genes de resistência à vassoura-de-bruxa, através de marcadores moleculares, a ser desenvolvida futuramente, deverá promover grande agilidade à seleção dos cultivares, visto que as análises poderão ser feitas com tecidos de plantulas recém-germinadas, encurtando o ciclo de melhoramento. 


\subsection{Seleção e utilização de descritores botânico-agronômicos}

Nos programas de melhoramento genético de plantas, são avaliados diversos caracteres morfológicos, fisiológicos, agronômicos e químicos, sendo a seleção dos indivíduos realizada, normalmente, com base em todas essas informações.

Porém, o controle genético da grande maioria dos caracteres de importância econômica é de natureza quantitativa, portanto, fortemente influenciados pelo ambiente, o que dificulta a seleção. Neste caso, a seleção com base em uma ou poucas características, não tem sido eficiente na identificação de genótipos que atendam a demanda do mercado. A abordagem da seleção combinada de vários caracteres, através da análise multivariada, permite discriminar, com mais eficiência, os materiais mais promissores (Cruz, 1990). A análise multivariada, para avaliação de um genótipo, baseada em caracteres quantitativos, parece ser um método lógico, considerando a existência de correlações entre essas variáveis. É possível que as informações de cada um dos caracteres se completem, e a análise do conjunto, resulte mais precisa do que as análises univariadas.

Além do mais, são necessárias técnicas eficientes para avaliação criteriosa dos acessos de um BAG, pois a limitação de infraestrutura (área experimental, recursos financeiros) e pessoal capacitado, exige que somente os recursos genéticos promissores para melhoramento tenham prioridade na conservação. Parte relevante da

variabilidade genética terá que ser conservada in situ para uso futuro. Materiais com muita similaridade genética, devem ser descartados ou intercambiados com outras instituições detentoras do germoplasma da espécie, enquanto aqueles pertencentes a diferentes grupos de similaridade devem ser conservados (Dias, 1994)

Técnicas multivariadas vêm sendo empregadas em diferentes coleções de germoplasma (Maluf \& Ferreira, 1983; Maluf et al., 1983; Barros, 1991; Soares,1991; Resende, 1991; Pereira, 1989; Cury, 1993; Daher 1993; Pires, 1993; Amaral Junior 1994; Dias, 1994; Bekele et al., 1994, Souza, 1996; Strapasson, 1997; Veasey, 1998; Conti, 1998), são alguns dos exemplos de estudos de germoplasma por técnicas multivariadas. Com o cupuaçuzeiro foram desenvolvidas pesquisas por Silva (1996) e Araújo et al.(2002). 
Em espécies silviculturais, de uma forma geral, e espécies relacionadas, que exigem um criterioso processo de seleção de cada indivíduo, a análise multivariada é largamente utilizada (Van Laar, 1987).

\subsubsection{Análise multivariada por componentes principais}

A utilização de componentes principais tem sido um dos métodos mais amplamente utilizados no melhoramento de plantas, uma vez que, além da distribuição gráfica da divergência entre os genótipos, ela possibilita a identificação dos caracteres menos e mais representativos para explicar a variação total (Pereira, 1989).

A idéia de Componentes Principais é que, combinando um conjunto de variáveis quaisquer, pode-se construir um novo grupamento, menos numeroso, de variáveis principais e que resumam a informação contida no grupo inicial. Cada componente principal é uma combinação linear das variáveis originais. Além disso, eles não são correlacionados entre si e construídos de maneira a explicar o máximo da variação total original. O primeiro componente tem a maior variância, sendo definido como aquele de maior importância por reter a maior parte da variação encontrada. $\mathrm{O}$ segundo componente tem a segunda maior variância, e assim sucessivamente (Cruz, 1990).

O emprego da técnica dos componentes principais para estudos sobre divergência genética em plantas, tem sido realizada com o propósito de manipular acessos em bancos de germoplasma, identificar genitores divergentes para hibridação, estabelecer relação entre diversidade genética e geográfica, estimar a variabilidade total disponível em grupos geneticamente relacionados, avaliar a uniformidade em cultivos e verificar a importância de cada caráter e promover a eliminação daqueles que contribuem pouco, em termos de variação, no grupo de indivíduos avaliados (Jeffers, 1972; Cruz, 1990; Dias, 1994).

Nos casos em que os primeiros componentes comportam uma percentagem relativamente alta da variação total, acima de $80 \%$, a variabilidade entre os indivíduos avaliados pode ser explicada satisfatoriamente apenas por esses primeiros componentes, simplificando a interpretação. Neste caso, a representação gráfica dos 
resultados é indicada. Quando este limite não é atingido, a análise é complementada pela dispersão gráfica em relação ao terceiro e quarto componente (Cruz, 1990).

Utilizando análise de componentes principais em 640 acessos de milheto, Hussaini et al., (1977) empregaram 18 variáveis e, com base apenas nos dois primeiros componentes principais, que explicaram $55,9 \%$ da variação total, obtiveram 12 agrupamentos de acessos. Rao et al., (1981) avaliando a divergência genética entre 120 acessos de arroz, observaram que apenas o primeiro componente principal explicava $87 \%$ da variação. Estudando 34 acessos de amendoim, Wilches (1983) verificou que $74 \%$ da variação observada era conferida pelos primeiros quatro componentes. Resende (1991) trabalhando com onze espécies do gênero Laelia, através de treze variáveis, observou que os dois primeiros componentes exploravam 94\% da variância total disponível, e que com eles poderia explicar a variabilidade entre as espécies de forma satisfatória. Em Sesbania sp., Veasey (1998) verificou que os dois primeiros componentes principais, obtidos a partir de dois conjuntos de dados, 17 caracteres morfológicos e nove caracteres agronômicos, acumulavam, cada um dos conjuntos, $74 \%$ e $77 \%$, respectivamente, da variação total.

Em um estudo detalhado com mandioca, Pereira (1989) utilizou a análise de componentes principais para estimar o grau de diversidade genética entre acessos do Banco Ativo de Germoplasma de mandioca. Foram avaliados 280 acessos através de 14 descritores botânico-agronômicos selecionados. Observou que a variância não se concentrou em poucos componentes, como nos trabalhos anteriores. Os seis primeiros componentes principais explicaram pouco mais de $50 \%$ da variância total entre os acessos. Concluiu que a variância encontrava-se bastante diluída entre todos os 14 componentes principais e que nenhum deles sozinho, foi capaz de resumir um volume de informação satisfatório. A discrepância com os resultados anteriores, foi explicada como decorrente da concentração da variância nos primeiros componentes estar associada a natureza e ao número de descritores utilizados na análise.

Tal fato não foi observado no trabalho de Dias (1994) em cacau, onde os dois primeiros componentes explicaram $71 \%$ da variação total disponível. Os quatro primeiros componentes eram responsáveis por $89 \%$ dessa variação. Fazendo um paralelo com os trabalhos de Pereira (1989) e Cury (1993) em mandioca, e Barros 
(1991) em caju, Dias (1994) verificou que a havia uma tendência da variância se dispersar por vários componentes principais. O autor sugeriu que a discordância poderia estar no tipo de descritor empregado. Isto porque utilizou caracteres restritos aos componentes de produção, enquanto que, nos demais, foram empregados descritores de natureza botânica ou botânico-agronômica.

Por outro lado, ainda nessa espécie, Araújo et al., (2002) avaliou 27 acessos do Banco Ativo de Germoplasma de cupuaçuzeiro - Belém, utilizando 11 descritores de fruto. Foi observado que os dois primeiros componentes principais explicavam mais de $70 \%$ da variação total, resultado que também foi concordante com os de Dias (1994) trabalhando com cacaueiro.

\subsubsection{Importância relativa dos caracteres para divergência}

A identificação dos descritores que mais contribuem para a discriminação entre genótipos e, consequentemente, na determinação da divergência genética, constitui outra vantagem da análise de componentes principais.

Normalmente os caracteres associados aos órgãos reprodutivos das plantas apresentam uma maior estabilidade do que os caracteres vegetativos. Hussaini et al. (1977) estudando o comportamento de 29 descritores botânicos-agronômico de milheto, concluíram que a maioria dos caracteres vegetativos, foram menos estáveis que os caracteres reprodutivos, frente às condições ambientais. Alguns caracteres vegetativos, porém, foram considerados relativamente estáveis. Outros resultados obtidos em milho por Goodman \& Paterniani (1969); em amendoim (Wilches, 1983) e Mandioca (Pereira, 1989), comprovam que os caracteres reprodutivos são mais estáveis que os vegetativos. Pereira (1989) salienta que, apesar de serem pouco estáveis, os caracteres vegetativos desempenham importante papel na taxonomia da mandioca.

O valor dos caracteres qualitativos para serem utilizados como descritores em cacau, foi demonstrado por Engels (1983a, 1983b). Porém, não despertam maiores interesses para o melhoramento, devido ao baixo valor agro-econômico (Bekele et al., 1994). Ainda em cacau, Bekele et al., (1994), concluíram que, os descritores reprodutivos, especialmente os de flor, apresentaram maior valor taxonômico que os 
descritores de folha, concordando com Ostendorf (1956), Enríquez \& Soria (1967) e Engels (1981). Isto pode ser explicado pelo maior controle genético e pressão de seleção exercidos sobre os caracteres reprodutivos, no processo de evolução. Dentre os caracteres reprodutivos o número de óvulos é o melhor indicador da produção e não é afetado, significativamente pelo ambiente (Lopez \& Enríquez, 1988).

Em cupuaçuzeiro, Silva (1996) observou, através de variáveis canônicas, que os cinco caracteres mais discriminatórios foram: diâmetro do pedúnculo da flor, comprimento do fruto, comprimento da lâmina da pétala, peso da casca e largura da lâmina da pétala. Dentre as cinco variáveis menos discriminatórias, espessura da casca, número de sementes, largura da cúcula, número de óvulos e comprimento da cúcula, coincidentemente, três também eram oriundas da flor. Concluiu que as variáveis originadas do fruto são tão discriminatórias, quanto às originadas da flor.

\subsubsection{Seleção de descritores botânico-agronômicos}

A utilização de grande número de descritores tem sido um procedimento generalizado na caracterização da variabilidade de germoplasma, em razão da ausência de informação precisa sobre a real contribuição de cada descritor. Todo caráter deve contribuir de alguma maneira para descrever a variabilidade, porém, à medida que cresce o número de descritores, aumenta também a possibilidade deles serem redundantes ou altamente correlacionados uns com outros. Consequentemente, ocorre acréscimo no trabalho de avaliação, o que não implica, necessariamente, em acréscimo de precisão da caracterização (Daher, 1993). Portanto, torna-se altamente desejável eliminar os descritores considerados redundantes, com baixa variabilidade, baixa estabilidade de expressão ou de difícil mensuração, enquanto isso não provoque perda significativa de informação geral (Pereira 1989).

A otimização do conjunto original de variáveis é processada através do descarte. O conjunto reduzido, deverá ser efetivo em acessar a variabilidade disponível e, significa, diminuição de custos operacionais, mão de obra e tempo despendidos na avaliação dos acessos. Sneath \& Sokal (1973) apresentaram uma longa discussão sobre os problemas relativos a seleção de caracteres para uso taxonômico, descarte de variáveis com baixa estabilidade ambiental e correlação entre caracteres. 
Vários procedimentos estatísticos encontram-se disponíveis para seleção de descritores e estudo de divergência genética. Análises de regressão e interdependência foram utilizadas por Beale et al. (1967), para decidir quais variáveis deveriam ser descartadas. O coeficiente de repetibilidade foi 0 procedimento empregado por Goodman e Paterniani (1969), para a escolha de variáveis apropriadas para a classificação de 55 raças e sub-raças de milho.

Porém, dentre todas as metodologias propostas, a mais rotineiramente utilizada é a análise multivariada por componentes principais. Possibilita identificar os descritores, variáveis ou caracteres mais importantes diante da variação total disponível entre os indivíduos avaliados. Desta forma, além de identificar os descritores de maior interesse, existe a possibilidade de eliminar aqueles que contribuem pouco para explicar a variação total.

A definição de uma metodologia segura para descarte de variáveis, sem alterar substancialmente a capacidade de discriminação dos acessos, surgiu à partir dos trabalhos de Jolliffe (1972 e 1973) que avaliou, com dados reais e simulados, quatro métodos de descarte de variáveis. Concluiu que, no caso de uso de componentes principais, os resultados serão mais satisfatórios se o número de variáveis rejeitadas for igual ao número de componentes cuja variância for inferior a 0,7 .

Mardia et al. (1979) complementou a metodologia anterior. Recomenda que sejam observados os componentes cujo autovalor seja inferior a $\lambda=0,70$. Em cada um desses componentes deve-se procurar o que apresenta o maior coeficiente em valor absoluto (autovetores), cuja variável correspondente deve ser descartada.

Utilizando essa metodologia, Pereira (1989) estudou 280 acessos do Banco Ativo de Germoplasma de Mandioca da EMBRAPA, conseguindo reduzir em $50 \%$ os 28 descritores botânico-agronômicos utilizados. Segundo o autor, essa redução proporcionou uma maior facilidade na realização e interpretação das análises.

Empregando a mesma metodologia no Banco Ativo de Germoplasma de capim-elefante constituído de 60 acessos, Daher (1993) reduziu o número de 
descritores de 22 para oito, o que corresponde a um descarte de $63,6 \%$ do conjunto original.

A metodologia proposta por Jolliffe (1972 e 1973) e Mardia et al. (1979), foi modificada parcialmente por Cury (1993) em um estudo com 30 acessos de mandioca. A proposta consistiu em descartar os caracteres que apresentavam os maiores coeficientes de ponderação (autovetores), nos últimos componentes principais (menores autovalores), conforme a metodologia original. Porém, a cada caráter descartado, era realizada uma nova análise com os caracteres remanescentes, sendo obtidos os novos autovalores. A análise tinha prosseguimento até não ser mais possível discriminar os maiores coeficientes dos autovetores ou pela inconsistência em descartar caracteres não redundantes. Após cada análise era observada a matriz de correlações fenotípicas entre as variáveis, para auxiliar no descarte daquelas consideradas redundantes. Foi observado que a partir do oitavo descarte, o critério tornou-se inconsistente, pois em cada ciclo de descarte apareciam mais de um descritor que era importante para aquele componente, tornando difícil a decisão de qual deles descartar. O número de variáveis a descartar não foi pré-fixado, como previa a metodologia original, que implicaria no descarte de $65 \%$ dos 20 descritores empregados. Com a modificação proposta, houve possibilidade de redução de $30 \%$ dos descritores utilizados (seis descritores), sem perda significativa de informações. Concluiu que o número de descartes não deve obedecer a um padrão rígido, conforme a metodologia inicial, sendo particular de cada caso.

Strapasson (1997) também empregou a metodologia proposta por Jolliffe (1972 e 1973) e Mardia et al. (1979), com pequenas adaptações. Como o número de acessos era muito inferior ao número de variáveis, as análises foram realizadas em cada um dos cinco grupos de descritores. Foi efetuada uma análise de componentes principais para as 15 variáveis reprodutivas, uma para as 22 variáveis vegetativas e três para cada avaliação agronômica. Com os descritores pré-selecionados foi realizada uma última análise, para definir o conjunto final. Verificou que oito descritores seriam os mais importantes na caracterização dos acessos, o que representa um descarte de $86 \%$ do total inicial. Concluiu, porém, que a metodologia proposta por Jolliffe (1972 e 1973) foi mais eficiente com os descritores reprodutivos e agronômicos que com os vegetativos. 
No gênero Theobroma começaram a surgir os primeiros trabalhos envolvendo a abordagem de análise multivariada nos anos 90. Dias (1994) adotou a metodologia modificada por Cury (1993). Trabalhou com uma coleção de 26 clones de cacaueiro, caracterizada através de 13 descritores de fruto e semente. Pelo critério empregado, quatro (31\%.) desses descritores foram descartados. Caso a metodologia adotada fosse unicamente a preconizada por Jolliffe (1972; 1973), deveriam ser descartados 10 dos 13 caracteres, ou seja, cerca de $76 \%$.

Ainda em cacau, Bekele et al. (1994) utilizaram 10 caracteres de folha, 22 de flor e 33 de frutos, recomendados pelo International Board for Plant Genetic Resources (IBPGR), em 53 acessos de cacaueiros adultos. Empregando técnicas de análise de componentes principais, identificaram 12 descritores considerados como os mais discriminativos, o que significou um descarte de $78 \%$.

Em cupuaçuzeiro, Araújo (2002) avaliou 27 acessos do Banco Ativo de Germoplasma de cupuaçuzeiro - Belém, utilizando 11 descritores de fruto. Verificou que a técnica de componentes principais foi efetiva na identificação de caracteres redundantes, sugerindo descartar três descritores.

\subsubsection{Avaliação da eficiência de descarte}

Além da simplificação no elenco de descritores, há necessidade de avaliar a eficiência do descarte, comparando-se o poder discriminante do conjunto de descritores originais com o subconjunto selecionado.

Algumas pesquisas criticam o procedimento de descarte de variáveis através de componentes principais, pela possibilidade de se eliminarem variáveis que possuem pesos consideráveis nos primeiros componentes, especialmente quando estes acumulam grande fração da variação total (Morais, 1992). Daher (1993), verificou que apenas um descritor apresentou essa situação, concluindo sobre a eficiência do método em descartar variáveis redundantes, para o estudo de divergência genética.

Algumas pesquisas sugerem que a avaliação da eficiência do descarte pode ser realizada comparando-se os agrupamentos dos acessos formados com base no conjunto de descritores originais e selecionados (Cury, 1993). Dias (1994) comparou o 
conjunto original de 13 variáveis em cacau, com o conjunto selecionado após o descarte (nove variáveis), através do método de agrupamento de Tocher. Observou que ambos conjuntos apresentavam agrupamento similar. Com isso ficou atestada a eficiência da metodologia utilizada. Bekele et al. (1994), também com cacau, verificaram através do método de agrupamento hierárquico que, o dendrograma baseado em todas as variáveis estudadas era muito semelhante aquele onde foi utilizada 34 variáveis selecionadas. Araújo (2000) avaliou 27 acessos do Banco Ativo de Germoplasma de cupuaçuzeiro - Belém, utilizando 11 descritores de fruto. Antes e após o descarte foram realizadas análises de agrupamento de Tocher, com onze e oito descritores, respectivamente. Foi observado a formação de cinco grupos de similaridade antes e quatro após o descarte.

Outra metodologia de avaliação da eficiência do descarte foi utilizada por Strapasson (1997), quando comparou o conjunto de variáveis originais com o grupo de variáveis selecionadas, através de medidas de similaridade, estimadas pelo coeficiente de correlação entre pares de componentes $\left(r_{1}\right)$ e entre dois conjuntos de componentes $\left(Q_{1}\right)$. Observou que o critério de descarte foi mais eficiente para as variáveis reprodutivas, que para as variáveis vegetativas.

\subsection{Utilização de marcadores moleculares para estudo de divergência genética}

O emprego de técnicas moleculares na caracterização dos acessos, além de orientar o programa de melhoramento na escolha dos cruzamentos mais adequados, poderá proporcionar um grande avanço na racionalização da instalação de novas coleções, permitindo entre outros, a constituição de coleções nucleares, onde cerca de $80 \%$ da variação genética de uma coleção pode ser representada por $10 \%$ dos acessos (Brown, 1989). Em se tratando de uma espécie como o cupuaçuzeiro, perene, onde cada planta ocupa $36 \mathrm{~m}^{2}$ de área, a utilização dessa ferramenta em muito contribuirá para redução dos custos de manutenção das coleções vivas à campo. $\mathrm{O}$ emprego de marcadores também poderá ser útil no estabelecimento da identidade dos acessos, permitindo detectar erros de identificação no campo (tanto dentro como entre os acessos), além de complementar a caracterização realizada com caracteres morfológicos e isoenzimáticos. Grandes coleções internacionais, como o Banco de Germoplasma Internacional de cacau, em Trinidad, estão sendo caracterizadas com 
caracteres morfológicos, agronômicos, isoenzimáticos e moleculares, com o objetivo de identificar duplicações, erros de identificação, e selecionar materiais promissores para o programa de melhoramento (Figueira e Cascardo, 2001).

Estudos de genética de populações ganharam grande impulso, à partir da década de 70, com o advento das técnicas de biologia molecular, especialmente marcadores isoenzimáticos. Porém, foi com o desenvolvimento de metodologias de marcadores moleculares baseados em polimorfismo ao nível de seqüência de DNA, que esses estudos ganharam uma poderosa ferramenta para caracterizar e avaliar recursos genéticos, especialmente para entender a estrutura e organização da diversidade genética das populações e seu monitoramento ao longo do tempo. No melhoramento vegetal, os marcadores são utilizados tanto para mapeamento genômico quanto para avaliação da diversidade genética (Figueira \& Cascardo, 2001).

A diversidade genética têm sido referida como a riqueza de espécies dentro de um ecossistema e também como o nível de variabilidade gênica existente dentro de cada população (Nei, 1973), que pode ser medida pelo nível de heterozigosidade esperada nas proporções do equilíbrio de Hardy-Weinberg, independente de efeitos de migração, seleção, mutação ou sistema reprodutivo. Weir (1996) concorda que a heterozigosidade é uma medida adequada para quantificar a variação, porém, também considera a frequencia de heterozigotos como um importante indicador da diversidade genética, uma vez que cada heterozigoto carrega alelos diferentes.

O cacaueiro, espécie economicamente mais importante do gênero, é a única que conta com um volume significativo de informações nessa área. Marcadores moleculares do tipo RFLP (polimorfismo de comprimento de fragmento digerido) e RAPD (polimorfismo de DNA amplificado aleatoriamente), têm sido empregados para avaliar os recursos genéticos e refinar a classificação do cacaueiro (Laurent et al., 1993; N'Goran et al., 1994). Uma ampla revisão sobre o emprego de marcadores moleculares em cacaueiro é apresentada por Figueira e Cascardo (2001).

\subsubsection{Marcadores microssatélites}

Dentre as técnicas disponíveis atualmente, a que envolve microssatélites tem sido muito utilizada em estudos de genética de populações de espécies silvestres, face 
à robustez, confiabilidade, praticidade operacional (Ferreira \& Grattapaglia, 1996), e por serem os marcadores mais informativos geneticamente (Grattapaglia, 1999).

O desenvolvimento da técnica de marcadores microsatélites expandiu os estudos de genética evolucionária para muitas espécies, que nas últimas duas décadas do século XX, era acessada basicamente por isoenzimas (Lewontin, 1991).

Microssatélites consistem em sequências repetidas em série em número variável encontradas nos genomas de plantas, adjacentes a sequências de cópia únicas, apresentando um alto nível de polimorfismo, com alelos possuindo um número variável de repetições básicas (Akkaya et al., 1992; Thomas \& Scott, 1993; Morgante \& Olivieri, 1993).

São marcadores baseados em sequência curtas (1 a 6 bases) repetidas (Litt \& Lutty, 1989), e estão sendo utilizados como marcadores para um ou vários locos (Akkaya et al., 1992; Thomas \& Scott, 1993; Morgante \& Olivieri, 1993).

Para amplificar uma ilha de microssatélite utiliza-se um par de primers, que são seqüências únicas de oligonucleotídeos, homólogos às regiões flanqueadoras dos microssatélites (Litt \& Lutty, 1989). Assim é possível obter uma amplificação específica da região que contém a sequência repetida, e o polimorfismo entre bandas será decorrente dos números diferentes de elementos simples repetidos. Cada segmento diferente de DNA representa um alelo daquele loco específico (Ferreira \& Grattapaglia, 1996).

Os microssatélites são co-dominantes, ou seja, ambos os alelos de um indivíduo heterozigoto são visualizados no gel, bem como, multialélicos e suficientemente estáveis para serem utilizados em análises genéticas, sendo ideal para aplicação em genética e evolução de populações naturais (Slatkin, 1995), especialmente em espécies arbóreas altamente heterozigóticas, como já vem sendo demonstrado tanto para espécies tropicais (Chase et al., 1996; Ferreira \& Grattapaglia, 1996), como temperadas (Steinkellner et al., 1997a). Os microsatélites apresentam vantagens sobre os métodos clássicos de genética quantitativa na análise da estrutura genética de populações, como: a herança genética das características detectadas (bandas no gel) podem ser facilmente demonstradas; a maioria dos locos são 
codominantes e as frequencias alélicas podem ser calculadas diretamente sem a necessidade de cruzamentos genéticos; as estimativas da variabilidade genética poder ser comparadas diretamente entre populações ou espécies e um conjunto de locos pode ser acessado usando-se pequena quantidade de material.

A utilização de marcadores microssatélites, pela sua neutralidade apresenta como principal vantagem a possibilidade de caracterização de forças evolutivas, sem a influência da seleção, permitindo uma maior compreensão do comportamento das populações naturais, em termos de deriva genética e migração.

Em plantas, os sítios microssatélites encontram-se amplamente distribuídos mais ou menos aleatoriamente por todo o genoma, com uma frequência de um a cada 50 mil pares de base, permitindo a mais completa cobertura de qualquer genoma eucarioto. Sua presença foi comprovada em 34 espécies vegetais, sendo que o elemento mais comumente repetido é o di-nucleotídeo AT (Morgante \& Olivieri, 1993). Trabalhando com cinco espécies arbóreas e o milho, Condit \& Hubbell (1991) foram os primeiros a documentar a presença de microssatélites em plantas.

Apesar da importância dos marcadores microsatélites para estudos de evolução e conservação genética, Hedrick (1999) relaciona três pontos que merecem ser levados em consideração com dados dessa natureza. A heterozigosidade tende a ser alta dentro das populações, o que acaba produzindo baixa diferenciação entre elas. Como esses locos são extremamente sensíveis à redução do tamanho populacional, em um curto espaço de tempo, podem gerar elevadas distâncias genéticas. Em terceiro, por serem marcadores neutros, diferenças estatísticas significantes podem não estar correlacionadas com diferenças biológicas expressivas, tanto por falta de correlação entre locos adaptativos e locos altamente variáveis, como também, pelo poder estatístico intrínseco desse locos, que é muito elevado.

Atualmente, microssatélites estão sendo empregados para a construção de mapas genéticos em cultivos anuais de importância econômica como soja, arroz e trigo (Akkaya et al., 1992; Rongwen et al., 1995; Zhao \& Kochert, 1993; Roder et al., 1995), além de espécies florestais como pinus (Smith \& Devey, 1994), fruteiras como citrus (Kijas et al., 1995) e banana (Jarret et al., 1993). 
A utilização de marcadores microssatélites em Theobroma restringe-se ao cacau, onde tem sido empregado para entender a origem e domesticação da espécie (Lanaud et al., 1999), assim como, para elaboração de mapas genéticos (Lanaud et al., 1999; Risterucci et al., 1997), e caracterização de germoplasma (Motamayor et al., 2001).

Um dos grandes entraves para utilização desses marcadores é o grande volume de trabalho necessário para o desenvolvimento de primers específicos para os loci de microssatélites de cada espécie. Porém, tem sido observado que ocorre conservação de sítios microssatélites entre espécies relacionadas. É possível, portanto, aproveitar primers, denominados heterólogos, que foram desenvolvidos para uma espécie e emprega-los nas demais espécies do gênero (Ferreira \& Grattapaglia, 1996).

Em levantamento com várias espécies realizado por Peakall et al., (1998) foi observado que, dentro do mesmo gênero, 50 à 100\% dos locos mantinham-se conservados, apesar de que nem todos eram informativos (20 à 100\% polimórficos). Em algumas espécies, porém, essa transferência é pouco efetiva, como relatado por Butcher et al., (2000) para Acacia mangium. Os autores atribuem à baixa transferibilidade observada, o grau de divergência evolucionária entre as diferentes seções e subgêneros, pois existe uma tendência geral em plantas de decrescer a amplificação e decrescer o polimorfismo, com o aumento da distância evolucionária em relação a espécie fonte, conforme também foi observado em Brassica (Lagercrantz et al., 1996), Eucalyptus sensu lato (Byrne et al., 1996), Quercus (Steinkellner et al., 1997b) e Leguminosae (Dayanandan et al., 1997).

No caso do gênero Theobroma, até o presente momento já foram isolados, sequenciados e avaliados mais de 49 pares de primers, pelo grupo do CIRAD, em Montpellier - França. Foi verificado que primers desenhados para cacau amplificavam várias outras espécies do gênero, inclusive o cupuaçuzeiro (Lanaud et al., 1999).

Alves et al., (2001) verificaram que primers heterólogos desenvolvidos para cacau foram eficientes na identificação e caracterização de acessos de cupuaçuzeiro. 


\subsubsection{Diversidade genética em populações de plantas}

O entendimento dos processos microevolutivos dentro das populações de plantas nativas, têm prosperado graças aos estudos da organização da variabilidade ou estrutura genética das populações, que visa a melhoria das estratégias de domesticação, manejo e conservação dessas espécies (Carthew, 1993).

Estrutura genética é definida como a distribuição não aleatória de alelos e genótipos dentro da espécie (Hamrick, 1982), ou ainda, a forma como a variabilidade genética é distribuída entre e dentro dos níveis hierárquicos de subdivisão de uma espécie (Brown, 1978).

O desenvolvimento e a manutenção da estrutura genética ocorrem devido às interações de um conjunto complexo de fatores evolucionários, com variação no conjunto gênico; organização desta variação dentro de genótipos; distribuição espacial dos genótipos; sistema de reprodução que controla a união dos gametas para a formação das progênies; dispersão das progênies; seleção; deriva; mutação; eventos casuais e processos de crescimento mortalidade e reposição dos indivíduos, que darão origem às populações futuras (Clegg, 1980; Hamrick, 1983; Loveless \& Hamrick, 1984; Hamrick, 1989). É de importância primária a seleção, o tamanho efetivo populacional e a habilidade da espécie em dispersar pólen e sementes (Hamrick, 1983). Em geral, a diferenciação entre as populações é aumentada pela seleção e deriva genética. Por outro lado, espécies com intenso movimento de pólen e sementes têm menor diferenciação do que espécies com fluxo gênico restrito (Hamrick, 1989).

Hamrick (1983) aborda a importância do conhecimento da variabilidade genética tanto dentro como entre as populações em dar suporte à conservação dos recursos genéticos. Há necessidade de entender como a variação encontra-se distribuída e quais as características do ambiente e da espécie influenciam essa distribuição.

Espécies que apresentam sistema misto de reprodução, mecanismos eficientes de dispersão de sementes e pólen, deverão apresentar alta variação genética dentro das populações e baixa entre. Por outro lado, espécies com pequenas populações, de autofecundação e/ou reprodução vegetativa, com limitada dispersão de 
pólen e sementes, deverão mostrar baixa variabilidade dentro e alta entre as populações (Loveless \& Hamrick, 1984; Hamrick \& Loveless, 1986).

Estudos da estrutura intrapopulacional de espécies arbóreas têm demonstrado que a distribuição de alelos e genótipos não é aleatória dentro das populações.Tal estrutura pode ser determinada pela dispersão de pólen e sementes, habitat de distribuição e seleção microambiental (Hamrick, 1983). Isto porque a frequencia alélica, na próxima geração, será influenciada pelo número de indivíduos que efetivamente trocarão alelos, especialmente em pequenas populações, e a taxa de homozigotos tenderá a crescer com a autofecundação os cruzamentos entre parentes, e entre indivíduos similares que ficaram próximos em decorrência de dispersão de pólen e sementes a curta distância. Estes cruzamentos, segundo Wright (1931), proporcionam a formação de demes panmíticos e reduzem a proporção de heterozigotos na população, caracterizando o efeito Wahlund. Essa redução pode ser quantificada pelo índice de fixação, a partir do teorema de Hardy-Weinberg.

Como em uma população existe limitação física que não permite o cruzamento de todos com todos, haverá maior probabilidade de cruzamentos entre indivíduos próximos que levam a redução dos heterozigotos e formação dos grupos, estruturando a população (Futuyma, 1992). Estes cruzamentos preferenciais conduzirão à fixação de certos alelos. Assim, por deriva genética ou endogamia, haverá formação de diferentes grupos, formando-se sub-populações divergentes. Paralelamente atuará o fluxo gênico introduzindo alelos nessas sub-populações no sentido de manter as frequencias alélicas próximas a média (Wright, 1931). Outra força evolutiva, seleção natural, atua no sentido de favorecer os alelos com maior valor adaptativo, ampliando ou reduzindo a divergência em função das variações ambientais existentes.

Parte da endogamia observada dentro de populações naturais de espécies arbóreas é determinada pela distância e taxa com que os genes migram dentro e entre populações Caso ocorra fluxo gênico a longa distância, a endogamia deverá ser baixa dentro das populações e haverá baixa divergência genética entre populações. Porém se o fluxo gênico for limitado, restringindo-se às árvores vizinhas, a taxa de endogamia deverá ser alta dentro das populações e haverá grande divergência entre as populações. Isto porque o cruzamento entre parentes gera endogamia, apesar de ser 
uma forma menos drástica do que a autofecundação efetiva, responsável por uma endogamia mais severa (Allard, 1971).

A análise da estrutura genética de populações também fornece subsídios para o entendimento da dinâmica evolutiva das espécies, que têm sido úteis para a conservação e melhoramento genético (Hamrick, 1989), manejo de populações naturais de essências florestais e fragmentação florestal, visando determinar os impactos da intervenção antrópica na variabilidade genética das espécies (Sebbenn et al., 2000; Seoane et al., 2001).

Para quantificar a estrutura genética das populações três metodologias têm sido empregadas: estatísticas F (Wright,1951 e 1965), diversidade gênica (Nei, 1973, 1977 e 1987) e análise de variância das frequencias gênicas (Cockerham, 1969). Devido ao fato do modelo de Wright (1951) e de Nei (1973) não considerarem o erro associado à amostragem, eles tendem a ser viciados, sendo este tanto maior quanto menor for o tamanho amostral. Porém, segundo Reis (1996), todas as três metodologias apresentam bases genéticas similares e são complementares em relação ao significado biológico das estimativas obtidas, especialmente se os marcadores forem neutros, a amostragem aleatória e as populações forem originadas de uma única população ancestral.

A análise das frequencias gênicas, (Cockerham, 1969), parte da pressuposição de que as populações são originadas de uma população ancestral, permitindo assim a estimativa de coeficientes de parentesco (coancestralidade) e endogamia. Outra pressuposição é a de que deriva genética e sistema de reprodução são os responsáveis pelos desvios de panmixia. Assim como as estatísticas $F$, análise das frequencias gênicas fornece informações sobre os níveis de fixação de alelos médios dentro das populações $(f)$ e totais das populações $(F)$ e a divergência genética entre populações ou o coeficiente de parentesco entre dois indivíduos dentro de populações $\left(\theta_{\mathrm{p}}\right)$.

\subsubsection{Correspondência entre distâncias genéticas e fenotípicas}

A divergência quando é baseada em dados fenotípicos, tem uma natureza fenética, não reproduzindo, necessariamente, a diversidade genética entre os acessos 
(Sneath \& Sokal 1973). A correlação entre divergência genética e fenética dependerá do componente ambiental embutido nos dados fenotípicos.

Quando a caracterização é realizada com dados morfológicos, a quantificação da diversidade entre acessos só tem sentido se a divergência fenética refletir a divergência genética (Dias 1994). Engels (1983b) ao comparar as relações genéticas entre 32 clones de cacau da Costa Rica, com as similaridades fenéticas expressas por dendrograma, detectou que os clones com um tipo parental comum conhecido, agruparam-se no mesmo grupo. Seus resultados confirmaram então que as relações fenéticas entre os clones representavam, com boa aproximação, as suas relações genéticas.

Dados bioquímicos e dados moleculares, em combinação com os dados morfológicos já tradicionalmente avaliados, podem ser submetidos também a análises multivariadas. A grande diferença é que os primeiros não sofrem influências ambientais (Dias 1994).

Deve ser ressaltado que marcadores genéticos são neutros e, portanto, não guardam associação com caracteres fenotípicos, ou agem como variantes casuais não influenciados diretamente pela seleção natural, permitindo a formulação de hipóteses relativas à quantidade, distribuição e manutenção da variabilidade genética (Cheliak \& Pitel 1984).

Na literatura a concordância entre esses tipos de dados, parece depender da espécie envolvida e das metodologias empregadas. Fryer (1987) encontrou padrões de variabilidade muito similares entre dados morfológicos e marcadores isoenzimáticos, quando estudou 15 populações de Pinus rigida, através de análises multivariadas. Barros (1991) trabalhando com 67 acessos de cajueiro avaliados por 30 caracteres morfométricos e marcadores isoenzimáticos, não encontrou concordância entre os dois conjuntos de dados. Em outro estudo com 60 acessos de capim-elefante através de 22 caracteres morfológicos e 4 sistemas isoenzimáticos, Daher (1993) observou que havia concordância entre os agrupamentos promovidos pelos padrões de bandas isozimáticas com padrões morfológicos. As correlações entre as estimativas de similaridade e distância genética foram estatisticamente significativas. Moraes (1992) estudou a estrutura genética de duas populações de Myracrodruon urundeuva, por 
isoenzimas e caracteres quantitativos, obtendo alta congruência nos resultados. Veasey (1998) verificou que as análises de agrupamento realizadas tanto com dados agronômicos como isoenzimáticos, concordaram ao separar espécies anuais de Sesbania sp. de espécies perenes.

\subsubsection{Correspondência entre distância genética e geográfica}

Embora a literatura seja conflitante, alguns trabalhos têm sugerido que a diversidade genética pode estar relacionada à diversidade geográfica. Cada espécie tem sua própria história vital. E, nesse sentido, fatores como seleção, deriva genética, fluxo gênico, segregação e outros podem atuar conjunta ou isoladamente e a diferentes intensidades sobre uma dada espécie e, com isso, determinar a existência ou não de algum paralelismo entre diversidade geográfica e divergência genética (Dias 1994).

A diversidade de origem e a diversidade ecogeográfica têm sido utilizadas como critério de divergência genética, na falta de informações sobre a capacidade de combinação, quando da escolha de indivíduos a serem utilizados como parentais para os cruzamentos em plantas cultivadas (Barros, 1991). Esse autor observou que a variabilidade encontrada entre os acessos de cajueiro coletados no estado do Ceará era maior que entre os acessos introduzidos. Sugeriu que a variabilidade observada estaria associada muito mais ao estágio de domesticação da planta do que à diferenças em função da geografia, pois o material estudado é, provavelmente, mais variável por manipulação pelo homem do que por alterações adaptativas com relação ao ambiente. Segundo Murty \& Arunachalam (1966) o aumento da distância geográfica entre populações não implica em maior divergência genética. A esse respeito Upadhyay \& Murty (1970) acrescentam que a deriva genética e a seleção em diferentes ambientes podem causar maior divergência que a distância geográfica. Reis (1996) caracterizando a estrutura genética de oito populações de Euterpe edulis na mata atlântica, observou menor divergência entre as populações contíguas, sugerindo que o modelo de isolamento por distância, reforçado pelo gradiente altitudinal em escala ampla, seria a forma básica de organização da variabilidade genética da espécie. 
A ausência da relação entre diversidade ecológica e geográfica com divergência genética também tem sido relatada em outras culturas como arroz, (Singh et al., 1979); algodão perene (Amalraj, 1982) cevada, (Varma \& Gulati, 1982), mandioca (Cury, 1993) e capim-elefante (Daher, 1993).

Em cacau, Bekele et al., (1994) e Dias (1994) demonstraram apenas uma correlação parcial entre origem geográfica e agrupamento por distância genética.

Em cupuaçuzeiro Silva (1996) observou correlação positiva entre a área geográfica de procedência e a divergência genética entre os acessos. Porém, salienta que o número de clones utilizados era pequeno para extrair conclusões definitivas sobre a espécie. 


\section{DIVERSIDADE GENÉTICA EM POPULAÇÕES DE CUPUAÇUZEIRO, Theobroma grandiflorum (Willd. ex Spreng.) Schum. UTILIZANDO MARCADORES MICROSSATÉLITES}

\section{Resumo}

Este trabalho teve por objetivo caracterizar e analisar a estrutura genética de sete populações de Theobroma grandiflorum, uma das fruteiras arbóreas mais importantes da Amazônia brasileira, utilizando marcadores microssatélites, com vistas a incrementar o programa de melhoramento e recursos genéticos, e auxiliar no processo de domesticação da espécie. Foram estudadas três populações naturais, coletadas na suposta área de máxima diversidade da espécie, três populações estabelecidas em Banco de Germoplasma, e uma população coletada em plantios comerciais. Foi observada alta variabilidade genética na espécie, ressaltada pelo elevado número de alelos por loco, alto nível de heterozigosidade e divergência entre as populações. A divergência entre as populações naturais pode indicar um processo preliminar de diferenciação. Essa divergência foi mais acentuada entre as populações oriundas de Tucuruí e Nova Ipixuna, corroborando com as indicações que consideram essa região como o centro de máxima diversidade de $T$. grandiflorum. $O$ padrão de estruturação das populações naturais sugerem, como estratégia de conservação in situ, a definição de um número razoável de reservas genéticas, que seja suficiente para manutenção dos alelos raros a médio - longo prazo, bem como, nas coletas, a ênfase deverá ser de amostrar várias populações. Foi observada baixa divergência genética entre as populações do BAG, sendo que, a maior parte da variabilidade genética encontrava-se dentro das populações. A caracterização desses acessos permitiu colher os primeiros subsídios para o estabelecimento futuro de uma coleção nuclear. A elevada diversidade genética observada nos plantios comerciais, permite recomenda-los como uma fonte alternativa de genes e genótipos ao programa de melhoramento de $T$. grandiflorum. 


\section{Summary}

The objective of this work was to characterize the genetic structure of seven populations of Theobroma grandiflorum, an important tropical fruit tree of the Brazilian Amazonia using microsatellite markers, to support the breeding and genetic conservation program. Three wild populations, collected from the putative area of the species maximum diversity, three populations of the species established at the germplasm collection, and another one collected from commercial plantings were analyzed. A large genetic diversity of the species was detected based on the high number of alleles per locus; high heterozigosity and divergence among populations. The divergence among natural populations may represent a preliminary process of differentiation. This divergence was more pronounced between the populations from Tucuruí and Nova Ipixuna, corroborating to hypothesis that considers this region as the center of maximum diversity of $T$. grandiflorum. The structure of the wild populations suggests, for in situ conservation approach, the definition of a reasonable number of genetic reserves, enough to maintain rare alleles at medium to long term, as well as, for collections, sampling of various populations should be emphasized. A low genetic divergence was observed among the populations kept at the germplasm collection, and that most of the genetic diversity was within populations. The characterization of these accessions allowed the first insight for the future establishment of a core collection. The high genetic diversity observed in commercial plantings indicate the possibility to use them as alternative source of genes and genotypes for the breeding program of $T$. grandiflorum.

\subsection{Introdução}

O cupuaçuzeiro [Theobroma grandiflorum (Willd ex Spreng) Schum] é uma espécie arbórea, frutífera, tipicamente brasileira com centro de diversidade presumível no sul e sudeste do estado do Pará e oeste do Maranhão (Cuatrecasas, 1964). Atualmente encontra-se disseminada por todos os estados da região Norte, além de outros estados brasileiros e até mesmo no exterior. O gênero Theobroma, de origem exclusivamente neotropical, possui 22 espécies, incluindo o cacaueiro ( $T$. cacao) que, juntamente com os gêneros Herrania, Guazuma e Cola, pertencia a família 
Sterculiaceae, mas foi reclassificado para a família Malvaceaea sensu lato (Alverson et al., 1999).

As populações remanescentes de cupuaçuzeiro no sudeste do Pará ocorrem associadas com outras espécies de grande importância socio-econômica, como a castanha-do-Brasil (Bertholletia excelsa H.B.K.), e o mogno (Swietenia macrophylla King Vell.), uma espécie com ameaça de extinção (Uhl et al., 1997). Normalmente $B$. excelsa e $S$. macrophylla ocupam o dossel e T. grandiflorum o subdossel da floresta densa de terra firme, juntamente com outras espécies economicamente importantes, como jatobá (Hymenaea coubaril L.), tachi preto (Tachigalia paniculata Aubl.), muiracatiara (Astronium lecointei Aubl.), e andiroba (Carapa guianensis Aubl.). Considerando que esta região encontra-se sob forte pressão antrópica e grande parte das populações já desapareceram (Homma et al., 1996; Homma, 2000), existe, a necessidade de estabelecimento de áreas de conservação dessas espécies.

Além da preocupação com a conservação das populações naturais, a demanda por materiais melhorados estimulou o programa de melhoramento genético de cupuaçuzeiro a formar coleções ex situ, denominadas Banco Ativo de Germoplasma (BAG), para a conservação da variabilidade genética, e seleção preliminar de materiais promissores para o programa de melhoramento. A caracterização genotípica dessas coleções passou a ser uma necessidade imperiosa para o conhecimento e futura utilização da variabilidade genética disponível. Permitiria, por outro lado, quantificar e comparar a variabilidade retida nessas coleções com a existente nas populações naturais, com vistas a identificar necessidade de reamostrar populações subrepresentadas ou identificar áreas prioritárias de coleta.

Conhecer a variabilidade genética existente nos plantios comerciais, formados à partir de materiais não selecionados, em comparação com o que já está sendo mantido no BAG e o que, potencialmente, pode ser obtido nas populações naturais, são também informações relevantes para dar sustentabilidade biológica à cultura de $T$. grandiflorum.

Para quantificar a variabilidade genética existente entre e dentro de populações de plantas, o uso de marcadores moleculares têm se revelado uma ferramenta eficiente e, a cada dia mais acessível. Neste trabalho a técnica de 
microssatélite foi escolhida pelas características intrínsecas de marcador somaticamente estável, codominante, neutro, multialélico, robusto, com elevada reprodutibilidade e confiabilidade, assim como, pela simplicidade operacional (análise de reação em cadeia da polimerase ou PCR) e rapidez de análise, quando comparado com outras metodologias (Ferreira \& Grattapaglia, 1996). Trata-se de um poderoso marcador molecular para descrever a estrutura genética das populações, fluxo gênico e estimar parâmetros genéticos populacionais (Morgante \& Olivieri, 1993). Dados podem ser analisados como freqüências alélicas permitindo a análise genética das populações (Rivera et al., 1999). Esta técnica tem sido também utilizada para identificar acessos em bancos de germoplasma (Djè et al., 2000). A principal desvantagem no uso de microssatélites reside no alto custo e tempo requerido para desenvolver primers específicos para cada loco. Porém, tem sido observado que ocorre conservação de sítios microssatélites e seqüencias flanqueadoras entre espécies relacionadas. É possível, portanto, utilizar primers, denominados heterólogos, que foram desenvolvidos para uma espécie nas demais espécies do gênero (Ferreira \& Grattapaglia, 1996). As chances de sucesso nessa transferência é inversamente proporcional à distância evolucionária entre as duas espécies. No caso do gênero Theobroma, até o presente momento já foram isolados, seqüenciados e avaliados mais de 49 locos, pelo grupo do CIRAD, em Montpellier - França. Foi verificado que primers desenhados para T. cacao (cacaueiro) amplificavam microssatélites de outras espécies do gênero, inclusive o cupuaçuzeiro (Lanaud et al., 1999). A utilização rotineira de marcadores microssatélites no gênero Theobroma restringe-se ao cacaueiro, onde tem sido empregado para entender a origem e domesticação da espécie (Lanaud et al., 1999; Motamayor et al., 2001), assim como, para elaboração de mapas genéticos (Risterucci et al., 2000), e caracterização de germoplasma (Motamayor et al., 2001).

Este trabalho teve como objetivos caracterizar, quantificar e comparar a diversidade genética existente entre e dentro de sete populações de Theobroma grandiflorum, estabelecidas em condições silvestres, Banco Ativo de Germoplasma e áreas de produtores, por meio de marcadores microssatélites. Visou também avaliar se as populações naturais guardam algum tipo de estruturação espacial, e se existia correspondência entre dados fenotípicos e moleculares no estudo da diversidade genética entre acessos do Banco Ativo de Germoplasma. Foram feitas inferências 
sobre a estrutura genética dessas populações, para orientar o programa de melhoramento e conservação dos recursos genéticos da espécie.

\subsection{Material e métodos}

\subsubsection{Material vegetal}

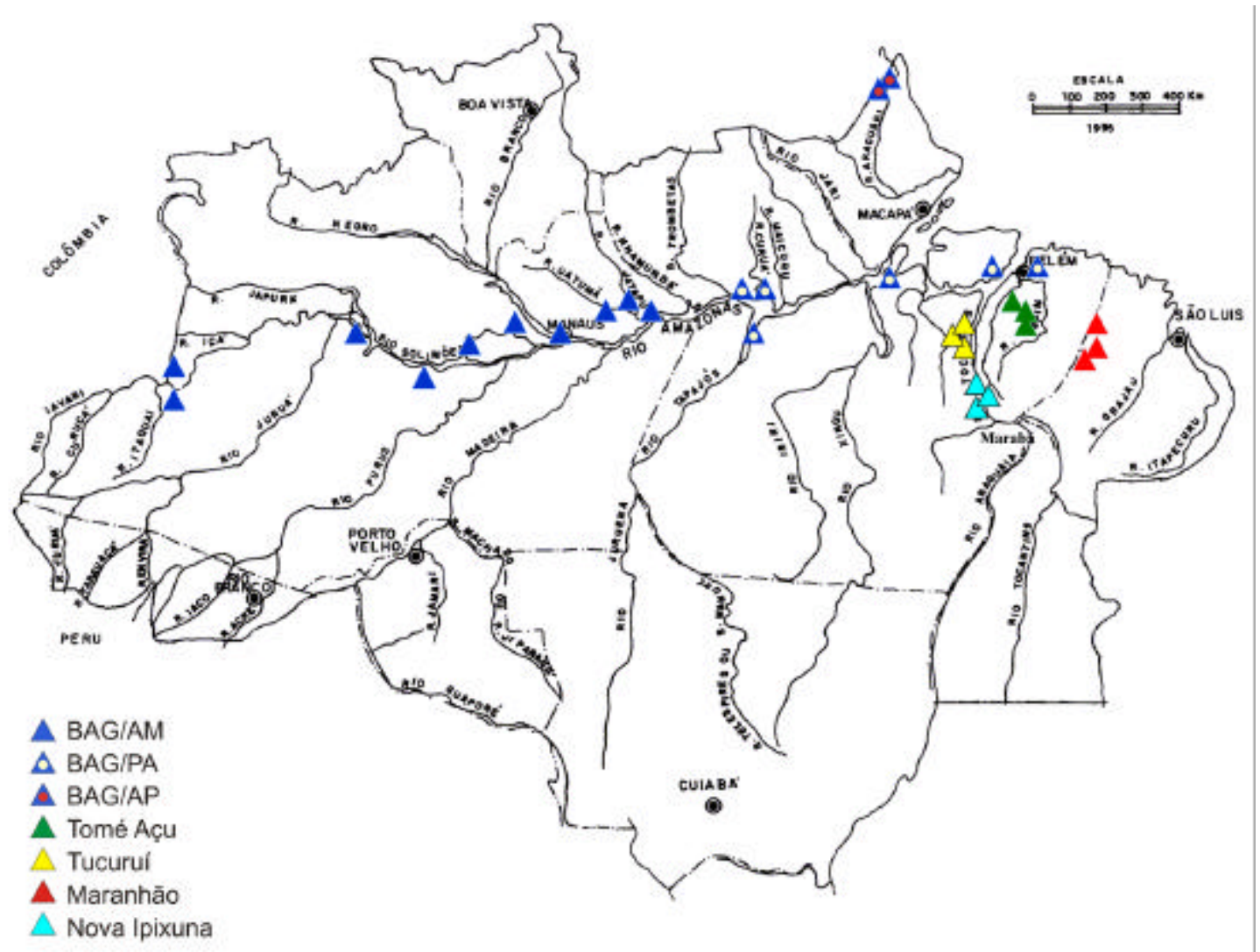

O material do estudo foi procedente de sete populações de Theobroma grandiflorum (Figura 1), sendo três populações naturais que ocorriam dentro da área considerada de máxima diversidade da espécie (Tucuruí, PA; Maranhão; e Nova Ipixuna, PA), três populações do Banco Ativo de Germoplasma de Theobroma grandiflorum da Embrapa Amazônia Oriental, em Belém, PA (populações Amazonas, Pará e Amapá) e uma população coletada em área de produtores (Tomé-açu, PA).Figura 1 - Locais onde foram originalmente coletados os acessos de cupuaçuzeiro.

Foi denominada população Tucuruí aos acessos que foram coletados pelo Instituto de Pesquisa da Amazônia (INPA) no município de Tucuruí, PA (4³’S; 495’ W), no local onde é hoje o grande lago da Usina Hidrelétrica de Tucuruí. Esses acessos foram plantados no Banco de Germoplasma do INPA, Manaus, AM. Os 
acessos coletados na pré-Amazônia Maranhense ( $\left.2^{\circ} 0^{\prime} \mathrm{S} ; 46^{\circ} 4^{\prime} \mathrm{W}\right)$ também pelo INPA foi denominada população Maranhão. A terceira população natural foi chamada Nova Ipixuna (Figura 1), cujos acessos foram coletados pelo autor em dezembro de 2001 no município de mesmo nome, no Estado do Pará (4ํ5's; 492ㄴW). Foi analisada uma amostra de 40 acessos de cada uma das populações.

O segundo grupo de populações amostradas proveio do Banco Ativo de Germoplasma de T. grandiflorum, estabelecido na Embrapa Amazônia Oriental em Belém, Pará (128'S; 48ํํ'W). Foram analisados 29 acessos coletados em diversos municípios do Estado do Amazonas (Figura 1), denominados população Amazonas; dez acessos coletados em municípios do Pará (população Pará); assim como sete acessos do Amapá (população Amapá). As coletas foram realizadas em pomares caseiros, pequenas propriedades rurais e áreas silvestres (Lima et al., Costa, 1986).

O terceiro grupo de acessos (população Tomé-açu) foi procedente de uma

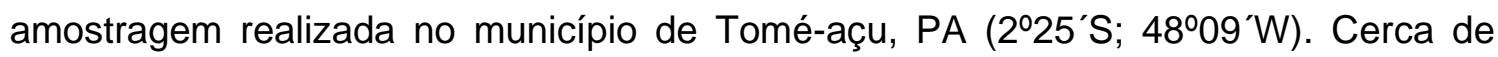
30.000 plantas produtivas em 12 propriedades agrícolas foram analisadas, e uma amostra final composta por 50 acessos selecionados nessas propriedades, foi clonada e plantada, na base física da Embrapa, no próprio município (Alves et al., 1998a).

Amostras de folhas de todas as populações foram secas em estufa ou liofilizadas e enviadas para o Laboratório de Melhoramento de Plantas do CENA-USP, Piracicaba, SP.

\subsubsection{Extração de DNA}

Para extração de DNA foi utilizado o protocolo de Doyle \& Doyle (1990), modificado por Figueira et al. (1997) para espécies do gênero Theobroma. Cerca de $150 \mathrm{mg}$ de tecido foliar foram triturados em cadinho de porcelana, na presença de nitrogênio líquido e, acondicionado em microtubos do tipo Eppendorf de 1,5 ml, aos quais foi adicionado $700 \mu \mathrm{l}$ de tampão de extração (1,4 M NaCl; 20 mM EDTA pH 8,0; $100 \mathrm{mM}$ Tris- $\mathrm{HCl} \mathrm{pH} 8,0 ; 1 \%$ Polivinilpirrolidona MW 10,000; $2 \%$ CTAB; $0,2 \% \beta-$ mercaptoetanol; 0,1 mg. $\mathrm{ml}^{-1}$ proteinase $\mathrm{K}$ ). Os tubos foram homogeneizados com vortex por $10 \mathrm{~s}$, e colocados em banho-maria à $55^{\circ} \mathrm{C}$ por $60 \mathrm{~min}$. A seguir, foi adicionado aos tubos contendo o extrato, $650 \mu \mathrm{l}$ de solução contendo 24 partes de 
clorofórmio para uma parte de álcool isoamílico (CIA v/v), para formar uma emulsão e, em seguida foram homogeneizados e centrifugados à $10.000 \mathrm{~g}$ por cinco minutos. $\mathrm{O}$ sobrenadante foi transferido para novos microtubos, aos quais foi adicionado $200 \mu \mathrm{lde}$ tampão de extração sem $\beta$-mercaptoetanol e proteinase $\mathrm{K}$, e foram cuidadosamente homogeneizados e centrifugados novamente à $10.000 \mathrm{~g}$ por cinco minutos. Após duas extrações com CIA, o DNA foi precipitado utilizando-se volume igual de isopropanol (400 $\mu \mathrm{l}$ aproximadamente). O DNA foi centrifugado e lavado com $1 \mathrm{ml}$ de etanol $70 \%$ para remover sais, e colocado para secar ao ar. O precipitado foi redissolvido em $20 \mu \mathrm{l}$ de tampão TE (10 mM Tris-HCl pH 8,0; 1 mM EDTA), contendo $10 \mu \mathrm{g} \cdot \mathrm{ml}^{-1}$ RNAse . A concentração de DNA foi determinada por fluorometria, utilizando-se fluorômetro DyNA Quant 2000 (Amersham Biosciences, Buckinhamshire, Reino Unido). Com base nessa determinação o DNA foi diluído e padronizada sua concentração para $5 \mathrm{ng} / \mu \mathrm{l}$.

\subsubsection{Marcadores microssatélites}

Para amplificação do DNA as reações foram preparadas com volume final de $13 \mu \mathrm{l}$, contendo $15 \mathrm{ng}$ de DNA genômico; $100 \mu \mathrm{M}$ de cada nucleotídeos (dATP, dTTP, dCTP, dGTP); 0,2 $\mu \mathrm{M}$ de cada primer (forward e reverse); tampão da enzima (50 mM $\mathrm{KCl} ; 10 \mathrm{mM}$ Tris- $\mathrm{HCl} \mathrm{pH} 8,8 ; 0,1 \%$ Triton X-100; $1,5 \mathrm{mM} \mathrm{MgCl} 2), 1$ unidade de Taq DNA polymerase (Life Technologies do Brasil, São Paulo, Brasil). Foram testados 48 pares de primers desenvolvidos por Lanaud et al. (1999a) para cacaueiro. As amplificações foram conduzidas nos termocicladores Perkin Elmer GeneAmp PCR System 9600 ou 9700 (Applied Biosystems, Foster City, EUA), programados, inicialmente, conforme Lanaud et al. (1999a): um ciclo de desnaturação à 94ํㅡ por quatro minutos, seguido de 30 ciclos de $94^{\circ} \mathrm{C}$ por $30 \mathrm{~s}, 46^{\circ} \mathrm{C}$ ou $51^{\circ} \mathrm{C}$ por $60 \mathrm{~s}$ e $72^{\circ} \mathrm{C}$ por $60 \mathrm{~s}$. Foram testadas também, outras ciclagens e temperaturas de anelamento para melhorar a resolução dos fragmentos amplificados.

Os produtos amplificados eram separados em gel desnaturante de $6 \%$ poliacrilamida e $7 \mathrm{M}$ de uréia, corrido em cuba vertical Hoefer SQ3 da Amersham Biosciences. Para realização da eletroforese, o tratamento das placas de vidro obedeceu ao seguinte procedimento: na placa maior, $33,3 \times 41,9 \mathrm{~cm}$, era aplicado $1 \mathrm{ml}$ a $2 \%$ de dimetildiclorosilano em octametil ciclo-octasilano (PlusOne Repel Silane ES, 
cat. \# 17-1332-01, Amersham Biosciences). Após secagem por cinco minutos, o excesso do produto era retirado com lenço de papel umedecido com água destilada. Na placa menor, $33,3 \times 39,4 \mathrm{~cm}$, era aplicado $3 \mu \mathrm{l}$ de metacriloxipropil - trimetoxisilano (PlusOne Bind Silane, cat. \# 17-1330-01, Amersham Biosciences), diluído em $1 \mathrm{ml}$ de uma solução contendo ácido acético glacial $0,5 \%$ em etanol $95 \%$. Após secagem, o excesso do produto era retirado com lenço de papel umedecido em etanol. As duas placas de vidro eram montadas com um espaçador de $0,5 \mathrm{~mm}$ de espessura, usando 0 aparato de sequenciamento SQ3 (Amersham Biosciences).

Para o preparo do gel foram utilizados $16 \mathrm{ml}$ de solução de acrilamida $30 \%$ (29 acrilamida:1 bisacrilamida); $16 \mathrm{ml}$ de 5 X TBE (54 g de Tris base, $27,5 \mathrm{~g}$ de ácido bórico e $20 \mathrm{ml}$ de EDTA 0,5 M pH 8,0); 33,6 g de uréia; $200 \mu \mathrm{l}$ de $10 \%$ persulfato de amônia (p/v); e $70 \mu \mathrm{l}$ de TEMED. A solução de acrilamida era aplicada no gel com auxílio de uma seringa plástica descartável.

Decorridos 60 minutos para polimerização, o conjunto de placas de vidro era instalado na cuba vertical de sequenciamento, colocando-se tampão 1X TBE nos respectivos compartimentos. A eletroforese tinha início com uma pré-corrida, para aquecer o gel, na potência constante de $60 \mathrm{~W}$ (em torno de $40 \mathrm{~mA}$ e $1400 \mathrm{~V}$ ) durante 60 minutos.

As amostras para eletroforese foram desnaturadas com a adição de $6 \mu \mathrm{lde}$ tampão de carregamento (constituído por 95\% formamida; 0,05\% xylenocyanol; 0,05\% de azul de bromofenol; $12,5 \%$ sacarose; $10 \mathrm{mM} \mathrm{NaOH}$ ), e colocadas à $94^{\circ} \mathrm{C}$ por 4 minutos, e mantidas em gelo até o carregamento no gel. Eram aplicados $10 \mu \mathrm{l}$ de reação em cada poço.

Posteriormente, após a aplicação das amostras, era realizada a corrida propriamente dita, com potência constante de $55 \mathrm{~W}$ durante duas horas. A coloração com nitrato de prata foi realizada conforme descrito por Creste et al. (2001). O gel, fixado na placa de vidro menor, era tratado com um litro de solução fixadora constituída de $10 \%$ etanol, acrescida de $1 \%$ ácido acético, durante 10 minutos e, posteriormente, lavado uma vez em água destilada por um minuto. Após a lavagem, o gel era tratado com um litro de uma solução de 1,6\% ácido nítrico por cinco minutos, seguido de duas 
lavagens em água durante um minuto. Na seqüência, o gel era tratado com um litro de uma solução de $2 \mathrm{~g}^{-1}{ }^{-1}$ nitrato de prata durante 20 minutos, e lavado em água por duas vezes durante um minuto. As bandas eram reveladas com uma solução de $30 \mathrm{~g}^{-1}$ $\mathrm{Na}_{2} \mathrm{CO}_{3}$ acrescida de $540 \mu \mathrm{l} . \mathrm{I}^{-1}$ de formaldeído até as bandas adquirirem a intensidade desejada. Eram colocados $500 \mathrm{ml}$ da solução até saturar e, uma vez descartados, eram colocados os $500 \mathrm{ml}$ restantes. Após o aparecimento das bandas essa solução era substituída por $1000 \mathrm{ml}$ de uma solução bloqueadora de $5 \%$ ácido acético, por cinco minutos. O gel era lavado em água destilada e ficava secando ao ar livre até ser fotografado.

\subsubsection{Análise Estatística}

Todas as populações foram caracterizadas a partir das frequências alélicas, dos índices de diversidade genética intrapopulacionais e da distância genética. As freqüências alélicas foram estimadas para cada população por: $\hat{p}_{i j}=n_{i j} / n_{\text {.j }}$ em que $\hat{p}_{i j}$ é a freqüência do alelo $i$ na população $j ; n_{i j}$ é o número de ocorrência do alelo i na população $j ; n_{. j}$ é o número total de alelos amostrados na população $j$. Estas estimativas foram obtidas para locos com oito ou menos alelos com auxílio do programa BIOSYS-1 (Swofford \& Selander, 1989). Para locos com mais de oito alelos, as freqüências gênicas foram calculadas diretamente dos fenótipos observados nos géis.

A diversidade genética intrapopulacional foi caracterizada pela porcentagem de locos polimórficos $(\hat{P})$, número médio de alelos por locos $(\hat{A})$, heterozigosidade observada $\left(\hat{H}_{o}\right)$, heterozigosidade esperada $\left(\hat{H}_{e}\right)$ em equilíbrio de Hardy-Weinberg, índice de fixação $(\hat{f})$ e tamanho efetivo populacional $\left(\hat{N}_{e}\right)$ utilizando o programa GDA (Lewis \& Zaykin, 1999). O índice $\hat{P}$ foi estimado pela média aritmética do número de locos polimórficos pelo número total de locos, sendo que um loco foi considerado polimórfico quando a frequêencia do alelo mais comum não ultrapassava $95 \%$. O índice $\hat{A}$ foi obtido pela divisão do número total de alelos pelo número total de locos. A heterozigosidade $\hat{H}_{o}$ para cada loco foi estimada por $\hat{H}_{o}=1-\sum P_{i i}$ em que $P_{i i}$ é a 
freqüência dos genótipos homozigotos. A heterozigosidade $\hat{H}_{e}$ para cada loco foi obtida segundo Nei (1977) por: $\hat{H}_{e}=1-\sum p_{i}^{2}$ onde: $p_{i}$ é a freqüência alélica estimada do $i$-ésimo alelo. A estimativa média sobre os locos de $\hat{H}_{o}$ e $\hat{H}_{e}$ foi obtida pela média aritmética entre todos os locos analisados (monomórficos mais polimórficos). $O$ índice de fixação não viesado $(\hat{f})$ foi estimado de acordo com Weir (1996):

$$
\hat{f}=\frac{\left(\hat{H}_{e}-\hat{H}_{0}\right)+\frac{2}{2 n} \hat{H}_{o}}{\hat{H}_{e}-\frac{1}{2 n} \hat{H}_{o}}
$$

Para verificar se os valores médios de $\hat{f}$ eram diferentes de zero, assim como os índices acima descritos, estimou-se o intervalo de confiança a 95\% de probabilidade pelo método de reamostragem bootstrap, utilizando-se 10.000 reamostragens sobre os locos pelo programa GDA (Lewis \& Zaykin, 1999).

Para separar os efeitos do sistema de reprodução dos efeitos da deriva genética ou mutação, os locos foram inicialmente submetidos ao teste exato de Fischer, para verificar aderência ao Equilíbrio de Hardy-Weinberg (EHW). Os locos que apresentaram desvios desse modelo foram analisados quanto ao modelo de Equilíbrio de Endogamia de Wright.

O tamanho efetivo populacional $\left(\hat{N}_{e}\right)$ foi estimado para cada população de acordo com Vencovsky (1997) por $\hat{N}_{e}=n /(1+\hat{f})$, em que $n$ é o tamanho amostral e $\hat{f}$ é o índice de fixação.

A distribuição da variabilidade genética entre e dentro das populações foi caracterizada pela análise da variância das freqüências alélicas (Weir, 1996), considerando todos os efeitos do modelo como aleatórios. Assim, de acordo com Weir, a variável $x_{i j}$ corresponde ao alelo $j$ na população $i$, portanto, quando $x_{i j}$ estava presente, recebeu o valor 1 e quando estava ausente recebeu o valor zero. A análise de variância das freqüências alélicas foi realizada com base no modelo estatístico:

$$
Y_{i k l}=m+p_{i}+b_{k(i)}+g_{l(i k)}
$$


em que, $Y_{i k l}$ : freqüência do gene $l$, dentro do indivíduo $k$, dentro da população $i ; m$ : média geral da freqüência alélica; $p_{i}$ : efeito da população $i, \operatorname{com} i=1,2, \ldots, a ; b_{k(i)}$ : efeito do indivíduo $k$, dentro da população $i$, com $k=1,2, \ldots, b_{i} ; g_{l(i k)}$ : efeito do gene $l$, dentro do indivíduo $k$, dentro da população $i$, com $I=1,2, \ldots, n_{i k}$. Os parâmetros

estimados foram: $\hat{\theta}_{P}=$ divergência genética entre populações; $\hat{F}=$ índice de fixação médio para o conjunto das populações; $\hat{f}=$ índice de fixação médio dentro de populações. Para verificar se as estimativas médias de $\hat{\theta}_{P}, \hat{F}$, e $\hat{f}$ eram estatísticamente diferentes de zero, estimou-se o intervalo de confiança a $95 \%$ de probabilidade pelo método de reamostragem bootstrap. Utilizaram-se 10.000 repetições sobre os locos. As análises de variâncias e os bootstraps foram realizadas no programa GDA (Lewis \& Zaykin, 1999).

\subsubsection{Distância genética}

A distância entre pares de populações foi medida pela distância genética não viesada $\left(\hat{D}_{j}\right)$ de Nei (1978). O calculo de $\hat{D}_{j}$ foi obtido a partir do programa BIOSYS -1 (Swofford \& Selander, 1989). A medida de distância genética não viesada de Nei (1978) foi utilizada para o agrupamento das populações e para a construção de dendrogramas, pelo método de agrupamento de médias não ponderadas UPGMA no programa TFPGA (Miller, 1997). A estabilidade dos agrupamentos dentro do dendrograma foi testada por procedimentos de reamostragens, sendo utilizado 10.000 reamostragens bootstraps.

\subsubsection{Correlação entre distância genética e distância geográfica}

O padrão de variação espacial das populações foi analisado usando a estimativa do coeficiente de correlação entre a matriz de distância de Nei (1978) e a matriz de distâncias geográficas entre as populações silvestres. A distância geográfica foi estimada a partir das coordenadas geográficas originais utilizando 0 programaArcView GIS 3.2a (Esri, 2000). A significância dessa correlação foi testada pela estatística $z$ de Mantel (Manly, 1997), usando 5.000 permutações aleatórias, no programa TFPGA (Miller, 1997). A estatística $z$ possui uma correlação matricial com o $r$ de Pearson, sendo de fato utilizada para testar a significância de $r$ (Manly, 1997). 


\subsection{Resultados e discussão}

\subsubsection{Caracterização dos locos microssatélites em cupuaçuzeiro}

Para otimizar a resolução dos fragmentos amplificados, houve necessidade de aumentar a temperatura de anelamento de alguns primers (Anexo $A$ ), desenvolvidos por Lanaud et al. (1999a) para utilização em T. cacao. Dentre os 48 pares de primers testados, $21(43,8 \%)$ apresentaram perfis polimórficos (Figura 2). Para os demais primers testados, 9 pares $(18,7 \%)$ apesar de amplificarem produtos, não foram informativos (monomórficos) e 18 (37,5\%) não amplificaram nenhum fragmento (Alves et al., 2001). Em razão de primers de microssatélites desenvolvidos para $T$. cacao, terem amplificado com eficiência $(62,5 \%)$ locos de $T$. grandiflorum, confirmou a pouca divergência evolutiva entre essas duas espécies do gênero Theobroma, demonstrando que as sequências que flanqueiam os locos microssatélites são conservadas. Addison \& Tavares (1951) produziram híbridos entre $T$. grandiflorum e $T$. cacao, apesar das plântulas obtidas apresentarem baixo vigor, demonstrando uma razoável afinidade entre as espécies. Em trabalhos posteriores, plantas híbridas adultas foram obtidas do cruzamento envolvendo as duas espécies (Martinson, 1966).

Dentre os 21 pares de primers utilizados neste trabalho, os mais polimórficos foram CIR61, CIR26, CIR17 e CIR18, que amplificaram até 11, 10, 8 e 8 alelos, respectivamente, enquanto os primers CIR09 e CIR54 amplificaram apenas dois alelos. Utilizando marcação radioativa nas amplificações, Lanaud et al. (1999) obtiveram média de 5,6 alelos por loco analisando 24 genótipos de cacaueiro, enquanto que Motamayor et al. (2001) utilizaram 16 pares de primers em 103 indivíduos de cacaueiro de inúmeras procedências, e encontraram 150 alelos, com média de 9,4 alelos por loco. Sereno et al. (2001) verificaram polimorfismo em nove locos e média de 4,4 alelos por loco analisando 94 genótipos de cacaueiro (Anexo B), utilizando coloração de géis de poliacrilamida com brometo de etídeo. 

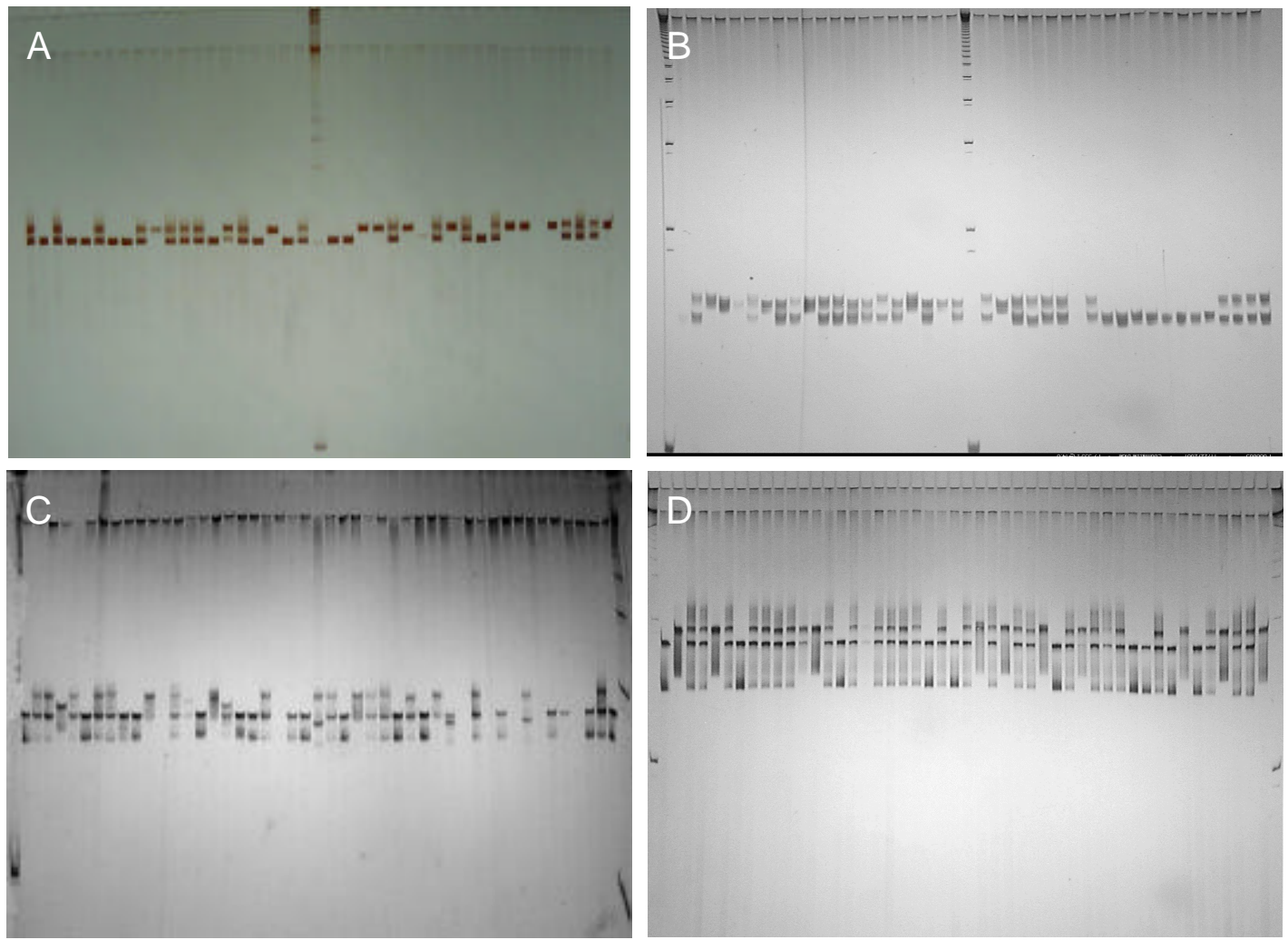

Figura 2 - Géis de poliacrilamida mostrando variabilidade, por microssatélites, entre os acessos das populações: A) Maranhão (primer CIR 17); B) Tucuruí (primer CIR61); C) BAG (primer CIR 18); D) Tome açu (primer CIR 18).

No presente trabalho, o polimorfismo revelado pelo número de alelos por loco, foi ligeiramente inferior aos trabalhos com $T$. cacao, em razão, possivelmente, de serem primers heterólogos, ou das características intrínsecas das populações analizadas. O sistema de coloração utilizado nesse estudo (nitrato de prata) pode também ter decrescido a sensibilidade de detecção dos alelos. Contudo, foi perfeitamente possível identificar e discriminar os acessos e caracterizar as populações, avaliando a variabilidade e estrutura genética entre e dentro de populações de $T$. grandiflorum. Os resultados demonstraram a viabilidade do uso imediato dos marcadores microssatélites, sem a necessidade do desenvolvimento de 
primers específicos para cupuaçuzeiro, com a conseqüente economia de recursos humanos e financeiros.

\subsubsection{Caracterização das populações}

Com base na amplificação utilizando 21 pares de primers de microssatélites, em média, as sete populações apresentaram 74,1 alelos (Tabela 1), com uma variação de 58 (Amapá) a 106 alelos (Amazonas). Em relação ao número médio de alelos por loco polimórfico, a população Amazonas apresentou número médio mais elevado (4,95 alelos) em relação a média geral (3,51 alelos).

Tabela 1. Estimativas de parâmetros genéticos em três populações naturais de cupuaçuzeiro, onde n: número de acessos amostrados; NA: número total de alelos; $\hat{P}$ : porcentagem de locos polimórficos; $\hat{A}$ : número médio de alelos/loco; $\hat{H}_{e}$ : heterozigosidade esperada sob equilíbrio de HardyWeinberg; $\hat{H}_{o}$ : heterozigosidade observada, $\hat{f}$ : índice de fixação e $\hat{N}_{e}$ : tamanho efetivo populacional, utilizando 21 locos microssatélites.

\begin{tabular}{|c|c|c|c|c|c|c|c|c|}
\hline População & $\mathrm{n}$ & $\overline{N A}$ & $\hat{P}^{z}$ & $\overline{\hat{A}}$ & $\hat{H}_{e}$ & $\hat{H}_{o}$ & $\hat{f}$ & $\hat{N}_{e}$ \\
\hline Tucuruí & 40 & 68 & 0,857 & 3,24 & 0,422 & 0,339 & $0,198^{*}$ & 34 \\
\hline Maranhão & 40 & 77 & 0,809 & 3,67 & 0,452 & 0,374 & $0,281^{\star \star}$ & 32 \\
\hline Nova Ipixuna & 40 & 67 & 0,857 & 3,19 & 0,392 & 0,353 & $0,102 n s$ & 37 \\
\hline Amazonas & 29 & 106 & 0,909 & 4,95 & 0,502 & 0,375 & $0,277^{*}$ & 23 \\
\hline Pará & 10 & 68 & 0,863 & 3,18 & 0,427 & 0,395 & $0,050 \mathrm{~ns}$ & 10 \\
\hline Amapá & 07 & 58 & 0,818 & 2,77 & 0,444 & 0,337 & $0,279 \mathrm{~ns}$ & 06 \\
\hline Tomé-açu & 50 & 75 & 0,761 & 3,57 & 0,357 & 0,305 & $0,077 \mathrm{~ns}$ & 47 \\
\hline Média & 30,9 & 74,1 & 0,839 & 3,51 & 0,428 & 0,354 & 0,181 & 27 \\
\hline
\end{tabular}

A população Tucuruí apresentou 68 alelos, com média 3,2 alelos por loco. Os locos mais polimórficos foram o CIR17 e CIR18 com seis alelos cada, e o locos CIR09 e CIR30 encontravam-se fixados. A percentagem de locos polimórficos foi de $85,7 \%$, considerado-se como polimórficos apenas os locos em que a freqüência do alelo mais comum não excedia 95\%. Na população Maranhão foram obtidos 77 alelos, que resultaram em 3,7 alelos por loco, e o loco CIR61, com nove alelos, foi o mais 
polimórfico, e apenas um loco (CIR45) estava fixado. Foram observados $80,9 \%$ locos polimórficos. Já a população de Nova Ipixuna apresentou 67 alelos, totalizando 85,7\% de locos polimórficos, pelo critério estabelecido. Novamente o loco CIR61 foi o mais polimórfico, com oito alelos, e três locos (CIR09, CIR30 e CIR54) estavam fixados. Foram observados em média 3,2 alelos por loco. A análise da freqüência alélica dentro de cada grupo (Anexo C) demonstrou, portanto, que as três populações naturais (Tucuruí, Maranhão e Nova Ipixuna) apresentaram níveis de riqueza alélica similares, em relação aos parâmetros estudados.

Uma análise comparativa da freqüência alélica das três populações que compõem o BAG de $T$. grandiflorum indicou a maior riqueza alélica da população Amazonas, sendo a única que não apresentou loco fixado. A população Amazonas apresentou 106 alelos com média de 4,95 alelos por loco. Os locos mais polimórficos foram CIR26 e CIR61 com 10 e 11 alelos, respectivamente. A riqueza gênica da população do Amazonas foi confirmada pela alta percentagem de locos polimórficos (91\%). Deve-se considerar também que a população Amazonas contém 29 dos 46 acessos do BAG (63\%), o que explica, em parte, esta alta variabilidade. Além do tamanho amostral, a variabilidade observada dentro dessa população decorre da amplitude da amostragem de coleta realizada, visto que, as coletas foram efetuadas ao longo da calha do rio Amazonas, abrangendo uma vasta área, indo do Leste (município de Parintins) ao extremo Oeste do Estado do Amazonas (Município de Benjamim Constant). Na população Pará foram encontrados 68 alelos com $86 \%$ dos locos polimórficos, e média de 3,18 alelos por loco. Os locos mais polimórficos foram CIR25 e CIR61 com seis alelos cada. As diferenças nas freqüências alélicas encontradas dentro das populações do BAG, podem ser decorrente, em grande parte, ao pequeno tamanho e a erros de amostragem. A população Amapá está também fracamente representadas no BAG de cupuaçuzeiro, com 7 acessos (15\% da coleção). O total de alelos observado, entretanto, foi relativamente elevado no total de 58 alelos, com média de 2,77 alelos por loco. O loco mais polimórfico novamente foi o CIR61 com seis alelos, sendo que $82 \%$ dos locos foram polimórficos. A população Amapá foi a que apresentou a maior percentagem de locos fixados (18,2\%). Novas coletas nesse estado, porém, não são prioritárias em função de não ser área de distribuição natural da espécie(Tabela 1). 
$\mathrm{Na}$ análise da população dos produtores de $T$. grandiflorum de Tomé-açu, PA foram obtidos 75 alelos, havendo cinco locos fixados. O loco mais polimórfico foi o CIR61 com 10 alelos. A percentagem de locos polimórficos foi de $76,1 \%$, tendo em média 3,6 alelos por loco.

Em termos gerais as sete populações estudadas apresentaram níveis de riqueza alélica relativamente altos e distintos. Características peculiares na constituição da população Amazonas, formada por acessos coletados em uma ampla área geográfica, podem explicar tanto o elevado número de locos polimórficos como também a presença de $92 \%$ dos alelos exclusivos (Figura 3). Por encontrar-se muito subdividida em uma vasta dimensão territorial é possível que a deriva genética e ausência de fluxo gênico sejam as causas da variabilidade observada. Porém, existe um fator histórico na formação dessa população que pode ter definido sua estruturação. Por ser uma espécie pré-Colombiana (Ducke, 1946), e o Estado do Amazonas não ser área de distribuição natural de T. grandiflorum (Cuatrecasas, 1964), pois somente é encontrado em condições sub-expontâneas ou de cultivo, todas as introduções da espécie, devem têm sido feita pelo homem. Diferentes introduções e locais isolados podem ter contribuído para a manutenção desses alelos exclusivos.

Por outro lado, a população Pará, cujo estado foi apontado como o centro de diversidade do T. grandiflorum (Cuatrecasas, 1964), encontra-se fracamente representada no BAG, pois as coletas foram efetuadas em um número muito restrito de municípios, fora da área de ocorrência natural da espécie (Lima \& Costa, 1991). Coincidentemente, esta região encontram-se sob forte pressão antrópica, acreditandose que grande parte desse reservatório gênico, já tenha sido perdido pela ação de madeireiras, expansão da fronteira agrícola e assentamentos de colonos. A exploração desordenada desses recursos podem causar profundas alterações genéticas nos ecossistemas, podendo vir a ter conseqüências desastrosas ao meio ambiente (Kageyama, 1987).

A elevada variabilidade genética ainda presente nas áreas de plantios comerciais de $T$. grandiflorum, em função das características heterogêneas do material 


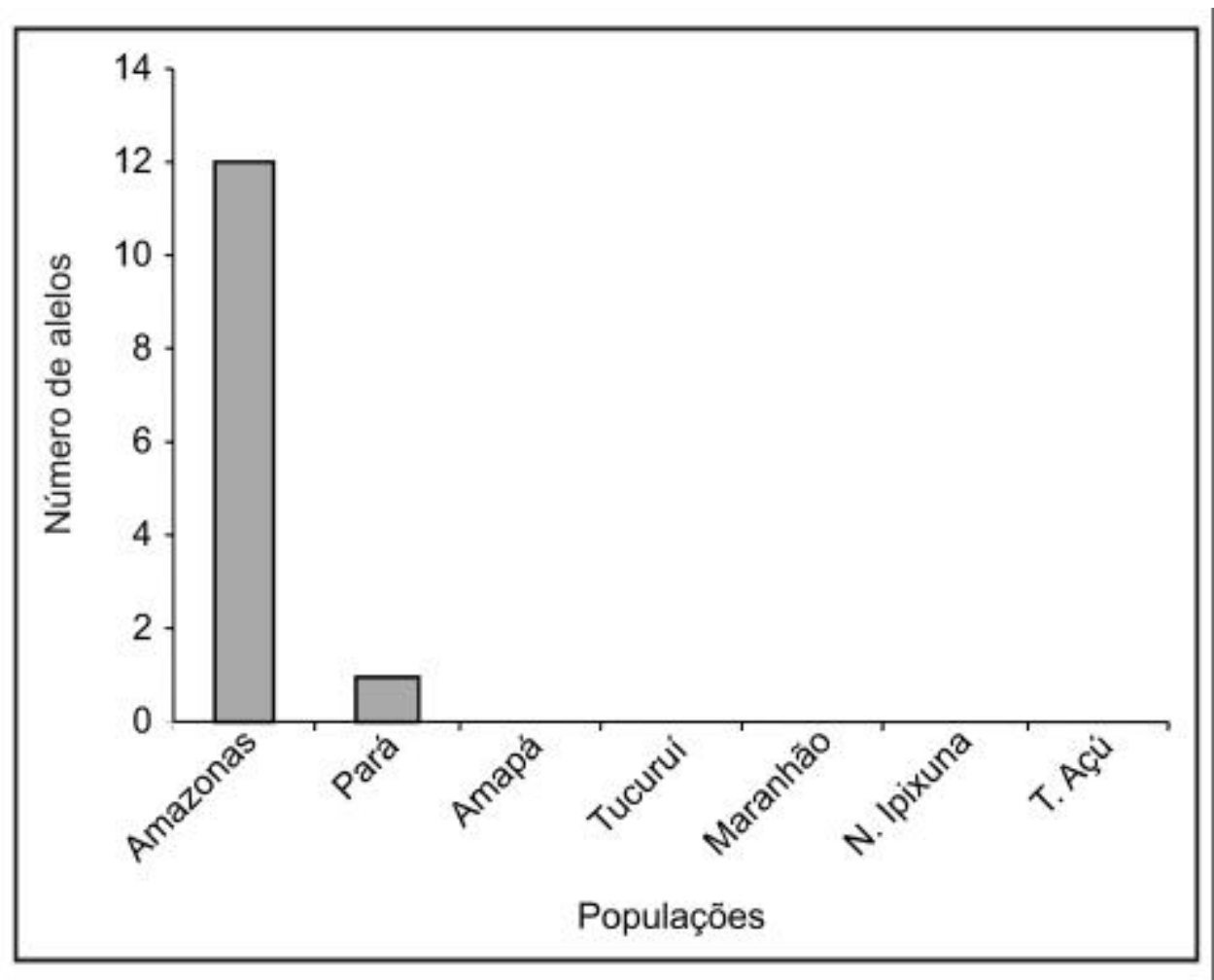

Figura 3 - Número de alelos exclusivos, identificados por microssatélites, em sete populações de cupuaçuzeiro.

de plantação, oferece oportunidade para identificação e seleção de materiais superiores, pois funcionam como um verdadeiro Banco de Germoplasma. Por esse motivo, algumas seleções preliminares já foram empreendidas nessas áreas (Alves et al., 1997c).

A heterozigosidade observada $\left(\hat{H}_{o}\right)$, no conjunto das sete populações, variou de 0,305 (Tomé-açu) para 0,395 (Pará) com uma média de 0,354, enquanto que, a estimativa da heterozigozidade esperada $\left(\hat{H}_{e}\right)$ foi mais elevada. O menor valor foi atribuído a população Tomé-açu $(0,357)$ enquanto a população Amazonas $(0,502)$ apresentou o maior valor. A heterozigozidade média esperada $\left(\hat{H}_{e}\right)$ foi de 0,428 . Em razão da heterozigosidade média observada ter sido inferior a heterozigosidade 
esperada em todas as sete populações, ficou caracterizado a presença de excesso de homozigotos. O aumento de homozigotos indicou a possível existência de um processo endogâmico, decorrente de desvios de panmixia, e/ou deriva genética, em razão da fragmentação da população original, ou efeito do fundador (Tabela 1).

No sub-grupo das populações naturais a heterozigosidade média esperada da população Maranhão $\left(\hat{H}_{e}=0,452\right)$ foi superior a da população Tucuruí $\left(\hat{H}_{e}=0,422\right)$ e Nova Ipixuna $\left(\hat{H}_{e}=0,392\right)$, sendo o mesmo detectado para os valores de heterozigosidade média observada $\left(\hat{H}_{o}\right)$. Esses altos níveis de heterozigosidade provavelmente decorrem do fato de que T. grandiflorum é uma espécie perene, autoincompatível (Alves et al., 1997c), cuja dispersão das sementes é feita por animais.

Nas populações que compõem o BAG, a heterozigosidade esperada em equilíbrio de Hardy-Weinberg variou de 0,427 (Pará) a 0,502 (Amazonas), com média de 0,458 . A heterozigosidade média observada $\left(\hat{H}_{o}\right)$ foi inferior a esperada em todas as populações, variando de 0,337 a 0,375 com média de 0,369 (Tabela 1).

Com a população de produtores (Tomé-açu), o comportamento não foi diferente. A heterozigosidade média esperada $\hat{H}_{e}$ foi de 0,357 , enquanto a observada $\hat{H}_{o}$ foi de 0,305 , acusando novamente excesso de homozigotos.

O índice de fixação médio de todas as sete populações $(\hat{f}=0,181)$ confirmou um nível relativamente alto de endogamia. Dentre as populações naturais, a população Nova Ipixuna teve o menor e não significativo índice de fixação $(\hat{f}=0,102)$, seguida da população Tucuruí ( $\hat{f}=0,198)$, cujo índice já foi significativo. A população com maior nível de endogamia ( $\hat{f}=0,281$ ) foi a Maranhão, cujo índice foi significativo, apesar de apresentar a maior riqueza alélica das três populações naturais. No BAG, o valor médio do índice de fixação entre as três populações foi 0,202 com uma variação de 0,050 a 0,279. Os índices de fixação das populações Pará e Amapá não foram significativos, somente na população Amazonas. Em relação as populações dos 
produtores a estimativa do índice de fixação $(\hat{f}=0,077)$ foi baixo e não diferente de zero. Portanto, a população dos produtores foi a que demonstrou a menor taxa de endogamia $(7,7 \%)$, em relação as populações naturais $(19,4 \%)$ e as populações do BAG $(20,2 \%)$ (Tabela 1).

Vale ressaltar que, pelo fato de locos microssatélites sofrerem altas taxas de mutação, os valores de $\hat{f}$ podem estar superestimados, pois há maior probabilidade dos alelos serem idênticos por estado do que por descendência (Slatkin, 1995). O coeficiente de endogamia pode ser superestimado, em razão de erros de amostragem e pela natureza mutacional dos marcadores microssatélites. Pois com tamanho de amostras pequeno é quase impossível capturar todos os possíveis genótipos de cada um dos locos, resultando em superestimativa da endogamia (Collevatti et al., 2001).

O modelo de equilíbrio de Hardy-Weinberg (EHW) possibilita testar se as frequencias genotípicas encontram-se nas proporções esperadas para populações de cruzamentos aleatórios e que não estejam sofrendo efeito de processos evolucionários como deriva, seleção, mutação e migração. O teste exato de Fisher (Anexo D) revelou que entre as populações naturais, Tucuruí e Maranhão apresentaram nove (43\%) e dez (48\%) locos, respectivamente, que não aderiram ao modelo de EHW, enquanto na população Nova Ipixuna apenas cinco locos (24\%) encontravam-se nessa situação. Dentre as populações do BAG, foi verificado que na população Amazonas $48 \%$ dos locos não atendiam ao EHW, enquanto um percentual mais baixo foi observado nas populações Pará (14\%) e Amapá (19\%). Na população dos produtores (Tomé-açu) o percentual foi relativamente alto (43\%). Desvios do EHW podem ser causados por fatores evolucionários e pelo sistema misto de reprodução. O modelo de EEW permite verificar quais destas duas causas estão efetivamente atuando. Dentre os locos de todas as populações que não aderiram ao EHW, em média, $68 \%$ também não estavam em concordância com o Equilíbrio de Endogamia de Wright (EEW), sugerindo a atuação de forças evolucionárias, provavelmente deriva genética. 


\subsubsection{Distribuição da Diversidade Genética Entre e Dentro de Populações}

O índice de fixação dentro das sete populações $(\hat{f}=0,181)$ acusou tendência de excesso de homozigotos, indicando que $18,1 \%$ dos cruzamentos dentro das populações podem ser endogâmicos, possivelmente decorrente de cruzamentos entre parentes. Por outro lado, o índice de fixação para a espécie como um todo $(\hat{F}=0,477)$ teve magnitude mais elevada e significante (Tabela 2). Portanto, o alto nível de endogamia decorre, em maior proporção, do efeito de deriva genética do que propriamente do sistema de reprodução.

A divergência genética entre as sete populações $\left(\hat{\theta}_{P}\right)$ foi alta e significativa $(0,362)$, demonstrando que $36,2 \%$ da variabilidade genética encontrava-se entre populações e, 63,8\% dentro das populações (Tabela 2). Esse índice elevado foi decorrente da contribuição importante da divergência entre o grupo das populações naturais $\left(\hat{\theta}_{P}=0,307\right)$, pois entre as populações do BAG a divergência foi relativamente baixa $\left(\hat{\theta}_{P}=0,026\right)$. Esse resultado foi um indicativo que as populações naturais de $T$. grandiflorum encontravam-se em forte processo de diferenciação. Espécies com ampla distribuição geográfica freqüentemente desenvolvem populações adaptadas localmente que, na maioria das vezes, são geneticamente distintas. Possivelmente, foi isso que aconteceu com as populações naturais de T. grandiflorum num passado recente. Porém, esse fenômeno tende a se acentuar com o avanço do desmatamento na região, promovendo redução no número e tamanho das populações, o que deverá ocasionar aumento de deriva e isolamento, pela limitação ou bloqueio do fluxo gênico. Ambas as forças promoverão incremento na diferenciação das populações.

Nas populações do BAG foram observadas grandes diferenças no número de alelos entre populações, inclusive com altas taxas de alelos exclusivos, porém baixa divergência entre as populações, sendo que $97,4 \%$ da variação observada encontravase dentro das populações. Uma possível explicação é que alelos com baixa freqüência contribuem pouco para a diferenciação entre populações. Alta divergência dentro e baixa entre populações tem sido observado em diferentes estudos com espécies de árvores tropicais (Hamrick \& Godt, 1990; Seoane et al., 2001). 
Tabela 2. Estruturação de três populações naturais (Maranhão, Tucuruí, N. Ipixuna), três populações do Banco Ativo de Germoplasma BAG (Amazonas, Amapá e Pará) e todas as sete populações de cupuaçuzeiro estudadas conjuntamente (acrescida da população dos produtores), considerando o número de populações de cada sub-grupo (n), e as estatísticas de Cockerham $\hat{f}, \hat{F}$ e $\hat{\theta}_{P}$, utilizando 21 locos microssatélites.

\begin{tabular}{lcccc}
\hline Populações & $\mathrm{n}$ & $\hat{f}$ & $\hat{F}$ & $\hat{\theta}_{P}$ \\
\hline Naturais & 3 & $0,161 \mathrm{~ns}$ & $0,418^{*}$ & $0,307^{*}$ \\
BAG & 3 & $0,225^{*}$ & $0,245^{*}$ & $0,026^{*}$ \\
Todas populações & 7 & $0,180^{*}$ & $0,477^{*}$ & $0,362^{*}$ \\
\hline
\end{tabular}

${ }^{*}$ significativamente diferente de zero através de 10.000 bootstrapping e $95 \%$ de intervalo de confiança; ns = não significante.

A elevada diversidade genética observada dentro das áreas de plantações dos produtores de T. grandiflorum do município de Tomé-açu, PA, e a facilidade de acesso, tanto para observações pontuais como para avaliações a médio prazo, permite recomendar essas plantações como uma fonte alternativa de genes e genótipos ao programa de melhoramento de $T$. grandiflorum. Essa diversidade dentro dos plantios comerciais, explica, em parte, as variações bruscas da capacidade produtiva de um planta para outra, dentro das linhas de plantio (Alves et al., 1997c).

\subsubsection{Distâncias genéticas}

As distâncias genética de Nei, calculadas entre pares de populações, variaram entre 0,019 e 0,99. Foi observado que as distâncias genéticas nas populações naturais, variaram de 0,271, entre Tucuruí e Maranhão, a 0,502, entre Tucuruí e Nova Ipixuna, tendo o valor intermediário de 0,414 entre Maranhão e Nova Ipixuna. A elevada diferenciação entre as populações Tucuruí e Nova Ipixuna, distanciadas em cerca de $100 \mathrm{~km}$, pode ser um índício que confirma a região Sudeste do Pará como a área de máxima diversidade do cupuaçuzeiro, conforme sugerido por Cuatrecasas (1964). Também foram observadas distâncias médias elevadas, em torno de 0,420, entre a população dos produtores (Tomé-açu) e as demais populações. Na Tabela 3 também são ressaltadas as distâncias genéticas elevadas entre a população dos 
produtores e as populações do BAG (em torno de 0,99), indicando que a procedência dos materiais era bastante divergente. Por outro lado, as baixas distâncias genéticas entre as populações componentes do BAG, sugerem que estas constituirem um grupo bastante homogêneo, com valores de identidade genética próximos a unidade, não acompanhando a tendência dos resultados com as demais populações. Todas estas inter-relações podem ser melhor visualizadas na Figura 4.

Tabela 3. Matriz mostrando na diagonal superior medidas de identidade não viezada de Nei (1978), e na diagonal inferior medidas de distâncias não viezadas de Nei (1978), entre sete populações de cupuaçuzeiro, utilizando 21 locos microssatélites.

\begin{tabular}{lccccccc}
\hline & Tucuruí & Maranhão & $\begin{array}{c}\text { Nova } \\
\text { lpixuna }\end{array}$ & Amazonas & Pará & Amapá & T.açu \\
\hline Tucuruí & - & 0,763 & 0,605 & 0,664 & 0,675 & 0,659 & 0,654 \\
Maranhão & 0,271 & - & 0,661 & 0,542 & 0,597 & 0,557 & 0,629 \\
Nova & 0,502 & 0,414 & - & 0,970 & 1,007 & 0,907 & 0,682 \\
Ipixuna & & & & & & & \\
Amazonas & 0,515 & 0,582 & 0,379 & - & 0,981 & 0,940 & 0,420 \\
Pará & 0,509 & 0,550 & 0,365 & 0,019 & - & 0,971 & 0,372 \\
Amapá & 0,518 & 0,573 & 0,404 & 0,062 & 0,029 & - & 0,372 \\
Tomé-açu & 0,425 & 0,463 & 0,383 & 0,867 & 0,990 & 0,990 & - \\
\hline
\end{tabular}

\subsubsection{Correlação entre distância genética x distância geográfica}

Para verificar se haviam correlações entre distâncias genéticas e as distâncias geográficas, submeteu-se as matrizes dessas distâncias ao teste de Mantel. 0 coeficiente de correlação obtido foi baixo e não significativo $(r=-0,13)$ indicando que as distâncias genéticas não podem ser explicadas pelas distâncias geográficas. Este resultado diferiu do obtido por Telles et al., (2001), onde a distribuição geográfica das subpopulações foi o principal fator responsável pela divergência genética em Eugenia dysenterica. Resultados semelhantes foram observados por Collevatti et. al., (2001) em 10 populações de Caryocar brasiliense, utilizando microssatélites, quando verificaram correlação positiva entre as matrizes de divergência genética e distância geográfica, indicando que o modelo de isolamento por distância explicaria a divergência genética 


\section{Distâncias}
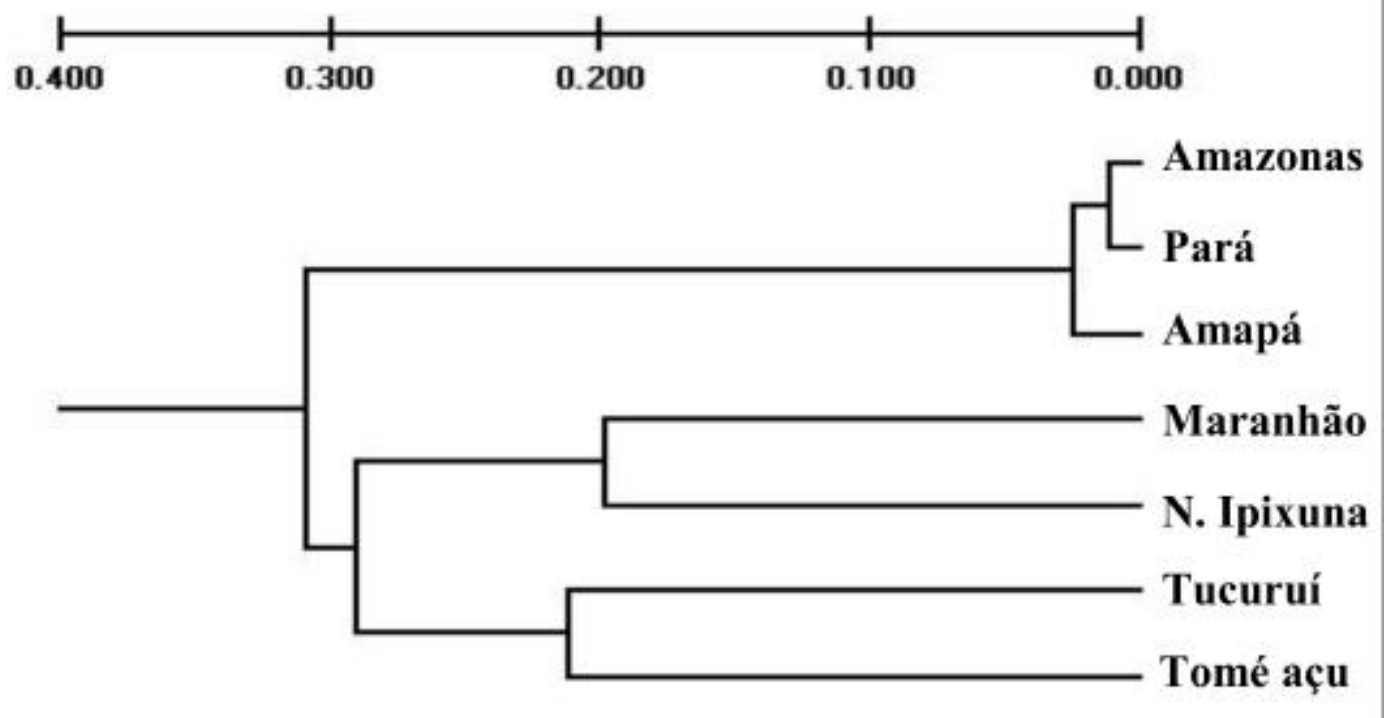

Figura 4 - Representação gráfica da análise de agrupamento, baseada nas distâncias genéticas não versadas de $\mathrm{Nei}$ (1978) de sete populações de $T$. grandiflorum, pelo método UPGMA, utilizando microssatélites.

entre as populações. A provável razão da discordância do presente trabalho com os supra-citados, decorra do baixo número de populações aqui analisadas.

\subsubsection{Conservação genética}

Os resultados mostraram que, nas populações naturais, cerca de dois terços da variabilidade total encontra-se dentro das populações e o terço restante entre as mesmas. Isto significa que as populações guardam um bom nível de divergência genética, quando comparado com outras espécies arbóreas tropicais, provavelmente em razão das distâncias entre as populações, o que traz como conseqüência desdobramentos sobre as estratégias de coleta de germoplasma e estabelecimento de reservas in situ. Como a variabilidade não concentra-se em uma ou poucas populações, a coleta deve ser ampla e privilegiar várias populações, sem prejuízo da 
amostragem dentro de populações. Para a manutenção da variabilidade da espécie in situ, o ideal é que várias áreas de conservação sejam estabelecidas.

Estes resultados divergem com aqueles obtidos por Sereno (2001) em populações silvestres de cacaueiro, onde observou forte estruturação intrapopulacional, porém fraca diferenciação entre populações. Também em seringueira, Paiva (1992) utilizando marcadores isoenzimáticos verificou que as duas populações estudadas, coletadas no Estado do Acre, eram muito pouco divergentes, recomendando que as coletas fossem realizadas em uma única população, com um maior número de indivíduos por população. A explicação para essa baixa diversidade seria decorrente da proximidade geográfica entre as populações, que na verdade deveriam compor uma única população. Com outra espécie arbórea Amazônica Bertholletia excelsa, foi observado resultado semelhante (Buckley et al., 1988). As populações estudadas foram coletadas no Estado do Acre e a outra no Estado do Amazonas, mas a divergência entre elas ainda assim foi baixa, apesar da distância geográfica. A explicação sugerida tanto para as populações de Bertholletia excelsa quanto Hevea brasiliensis foi semelhante, isto é, que as duas populações teriam sido originadas de uma população ancestral comum, ou mesmo tenha havido ação antrópica.

Conforme foi discutido anteriormente, a representatividade do BAG de $T$. grandiflorum de Belém, ainda é muito incipiente, visto que está em fase de formação. Portanto, novas introduções se fazem necessárias para dar suporte ao programa de melhoramento genético por um lado e, resgatar populações em eminência de desaparecerem. Porém, cada planta mantida no BAG representa $36 \mathrm{~m}^{2}$ de área à conservar, o que significa um custo de manutenção elevado. A única alternativa consiste em proceder uma triagem das mudas e, somente aproveitar para plantio aquelas geneticamente divergentes. Nessa etapa, a técnica de marcadores microssatélites poderá ser de grande valia. Outra providência seria analisar comparativamente os acessos estabelecidos pelas diversas instituições que mantêm coleções de T. grandiflorum na Amazônia, afim de evitar duplicidade de esforço. Entre estas coleções destacam-se a da Embrapa Amazônia Ocidental, com acessos coletados basicamente no estado do Amazonas e a do Instituto de Pesquisa da Amazônia (INPA), que mantêm acessos resgatados onde é o hoje o grande lago da 
barragem de Tucuruí, bem como, acessos coletados na pré-Amazônia maranhense. A importância desta última coleção, resulta de que ambas regiões, ocorrem dentro do centro de máxima diversidade de T. grandiflorum (Cuatrecasas, 1964). Além disso, as populações naturais de Tucuruí não existem mais e, as populações maranhenses encontram-se em franco processo de erosão genética. Uma amostra dessas duas populações (denominadas população Tucuruí e população Maranhão) foi analisada na presente pesquisa, onde ficou comprovada sua importância para o programa de recursos genético de $T$. grandiflorum.

Vale ressaltar que todas as coleções de $T$. grandiflorum, assim como as demais espécies perenes conservadas à campo, enfrentam sérios problemas de manutenção. Orçamentos cada vez mais reduzidos, pessoal insuficiente e descontinuidade administrativas provocadas por mudanças na curadoria das coleções, são algumas das causas de perdas de materiais, além de problemas de ordem biótica (pragas e doenças) e abiótica (fogo, seca entre outros), que dificultam a manutenção das coleções a médio e longo prazo. O cultivo in vitro e a criopreservação são alternativas promissoras de investigação, visto que, o método de conservação tradicional de germoplasma em câmara fria, não se presta ao $T$. grandiflorum, por apresentar sementes recalcitrantes, isto é, que não toleram dessecamento e baixas temperaturas. Outra alternativa que esta sendo muito utilizada em espécies com problemas de manutenção é o estabelecimento de coleções nucleares, que promovem uma redução drástica no número de indivíduos, porém ainda assim, preserva grande parte da variabilidade existente dentro do BAG. A caracterização dos acessos promovida neste trabalho, fornecerá subsídios para que uma coleção nuclear seja estabelecida numa etapa seguinte, possivelmente na área que concentra a maioria dos cultivos de $T$. grandiflorum no Estado do Pará, e funcionará como uma espécie de "cópia de segurança" do BAG.

\subsubsection{Melhoramento genético}

Como outras espécies de origem Amazônica, o T. grandiflorum enfrenta condicionantes biológicos quando cultivado nessa região. Entre estes destaca-se o fungo Crinipellis perniciosa causador da doença conhecida como vassoura-de-bruxa, que ataca também o cacaueiro e foi um dos responsáveis do Brasil ter perdido a 
posição de um dos maiores exportadores de T. cacao do mundo (Mascarenhas et al., 2000). No centro de origem de uma espécie co-evoluem, a vasta diversidade de patógenos que convivem com a espécie, e contribuem por sua vez, para a grande variabilidade genética observada nas populações naturais (Allard, 1971). Com a ampliação das áreas de cultivo de $T$. grandiflorum, esta enfermidade tornou-se cada vez mais importante, sendo que, nas regiões mais tradicionais, as perdas já começam a inviabilizar a cultura. A enfermidade ocorre com diferentes níveis de danos, variando de uma planta para outra, em razão, provavelmente, do controle genético e fatores ambientais (Alves et al., 1997c).

A grande variabilidade genética que existe dentro das populações naturais observadas no presente trabalho, bem como, a forma de distribuição das plantas dentro do complexo multiespecífico da floresta, provavelmente são os fatores que garantem a sustentabilidade biológica das populações. A busca por germoplasma resistente à vassoura-de-bruxa deve ser incrementada, com intuito de reunir no BAG diferentes fontes de resistência genética ao patógeno. Populações naturais, áreas de plantios comerciais, pomares caseiros deverão ser pesquisados. A exploração do vigor heterótico, onde características de resistência a vassoura-de-bruxa sejam associada a alta produção de frutos, continuará a ser uma das linhas de pesquisa, pois confere elevado ganho genético por ciclo de melhoramento, dando respostas mais imediatas para a demanda de material de plantação. Oferece entretanto riscos de quebra da resistência, visto que, o produto dessa linha de pesquisa são clones elites, porém, com base genética restrita. São materiais mais recomendados para produtores mais tecnificados, que terão condições de agregar, ao controle genético, caso necessário, outras práticas agronômicas como controle fitossanitário, envolvendo aplicações de fungicidas e poda profilática das vassouras (ramos) e frutos atacados. Para tentar minimizar o problema, a seleção dos clones deverá ser efetuada à campo, para que as manifestações de resistência horizontal sejam também consideradas.

Porém, para a grande demanda que é constituída por pequenos plantadores, o tipo de material de plantação deve ser outro, assim como a estratégia para obtê-los. À semelhança do que foi observado para as populações naturais neste trabalho, será fundamental que os plantios sejam efetuados com ampla base genética. Porém, conforme foi também aqui observado nas populações dos produtores (denominada 
população Tomé-açu), a elevada variabilidade encontrada muito se assemelhava às populações naturais ou ao BAG, sem que isso tenha resolvido o problema de sustentabilidade biológica (pois em geral os plantios estavam submetidos a forte ataque de vassoura-de-bruxa), que afetou diretamente a sustentabilidade econômica, com o decréscimo do número de frutos produzidos.

Portanto, a estratégia a ser adotada privilegiará o melhoramento populacional (Alves, 1999c). Somente que, os genitores que darão origem à população serão constituídos por clones comprovadamente resistentes a vassoura, portadores de diferentes fontes de resistência (oriundos da linha de pesquisa anterior), e clones altamente produtivos, também oriundos de diferentes procedências. Esses clones serão reunidos em um lote isolado de outros plantios, constituindo-se num pomar de sementes, onde seja maximizada as chances de cruzamentos, pois cada planta será arranjada no campo de forma que fique afastada da outra do mesmo clone, dispensando com isso o emprego de cruzamentos controlados. O produto final dessa linha de pesquisa será uma população melhorada de primeiro ciclo, que terá condições de interagir com a doença, à semelhança do que ocorre nas populações naturais, numa ação tampão muito parecida ao procedimento multi-linhas utilizado em plantas anuais, bem como, deverá apresentar uma produtividade média superior e mais estável que a observada nos plantios atuais. Nos ciclos seguintes será adotada a seleção recorrente que visará aumentar na população a freqüência dos genes responsáveis pelas características agronômicas mais importantes. Portanto, em relação a linha de pesquisa anterior, a expectativa é de ganhos genéticos menores, porém com maior estabilidade e longevidade da cultura no campo.

\subsection{Conclusões}

Primers de microssatélites, desenvolvidos para T. cacao, podem ser utilizados de forma eficiente na amplificação do T. grandiflorum, o que significa acesso imediato a essa tecnologia, e economia de recursos humanos e financeiros para desenvolver primers específicos. 
Os resultados obtidos demonstraram a existência de alta variabilidade genética na espécie, ressaltada pelo elevado número de alelos por loco, alto nível de heterozigosidade, e divergência entre as populações.

As três populações naturais apresentam níveis de riqueza alélica e índices de diversidade intra-populacionais relativamente semelhantes, 0 que enfatiza a necessidade de continuarem a ser adequadamente conservadas ex situ (Tucuruí e Maranhão), bem como candidata a população Nova Ipixuna ao programa de Recursos Genéticos do T. grandiflorum, para conservação in situ.

O nível de variabilidade, quantificada pela heterozigosidade média observada, ao nível das populações naturais, Banco de Germoplasma e área de produtores, é superior a média de outras espécies arbóreas tropicais, ressalvadas as diferenças entre as metodologias de quantificação. Indica que essa variabilidade encontra-se razoavelmente representada no BAG em relação as populações naturais. Porém, observa-se que nas plantações comerciais já existe uma tendência de redução dessa variabilidade, apesar de que, até o momento, nenhum material melhorado e, portanto, mais uniforme, tenha sido estabelecido.

A divergência entre as populações naturais pode indicar um processo preliminar de diferenciação. Essa divergência é mais acentuada entre as populações oriundas de Tucuruí e Nova Ipixuna, corroborando com as indicações que consideram essa região como o centro de máxima diversidade de $T$. grandiflorum.

A divergência entre as populações naturais e a moderada heterozigosidade encontrada sugere, como estratégia de conservação in situ, a definição de um número razoável de reservas genéticas, que seja suficiente para manutenção dos alelos raros a médio - longo prazo.

Em relação a conservação ex situ, as coletas devem ser realizadas em muitos locais, em decorrência da divergência entre as populações observada, porém, com pouca amplitude/intensidade em cada local, devido a variabilidade existente dentro das populações. 
Para produção de materiais de plantação que aliem resistência, produtividade estabilidade e segurança aos cultivos, deve ser priorizada a estratégia de melhoramento genético de populações, paralelamente ao melhoramento clonal;

No BAG é observada baixa divergência genética entre as populações, sendo que, a maior parte da variabilidade genética encontra-se dentro das populações. A caracterização desses acessos permite colher os primeiros subsídios para 0 estabelecimento futuro de uma coleção nuclear.

Dentre as populações que compõem o BAG, a Amazonas é a que tem maiores condições de contribuir com o programa de Recursos Genéticos e Melhoramento do T. grandiflorum, seja pelos níveis de diversidade genética, como também por deter a maioria dos alelos exclusivos identificados.

A elevada diversidade genética observada dentro das áreas de plantações dos produtores de T. grandiflorum do município de Tomé-açu, PA, e a facilidade de acesso, tanto para observações pontuais como para avaliações a médio prazo, permite recomendar essas plantações como uma fonte alternativa de genes e genótipos ao programa de melhoramento de $T$. grandiflorum. Essa elevada variabilidade genética dentro dos plantios comerciais, explica, em parte, as variações bruscas da capacidade produtiva de um planta para outra, dentro das linhas de plantio.

Apesar da alta variabilidade genética observada dentro das plantações dos produtores, há uma clara indicação que ela não representa toda a diversidade encontrada dentro das populações naturais ou nas populações do BAG, como já era esperado.

Não é observada correlação entre distâncias genéticas e geográficas, possivelmente devido ao pequeno número de populações naturais estudadas. 


\section{SELEÇÃO DE DESCRITORES BOTÂNICO - AGRONÔMICOS PARA CARACTERIZAÇÃO DE GERMOPLASMA DE CUPUAÇUZEIRO, Theobroma grandiflorum (Willd. ex. Spreng.) Schum}

\section{Resumo}

Este trabalho objetivou selecionar descritores botânico-agronômicos quantitativos para caracterizar acessos de Theobroma grandiflorum. Foram avaliados 53 descritores: 14 associados a características de folha; 18 à flor; 16 ao fruto; e 5 descritores agronômicos. Para o descarte dos descritores, foi empregada a técnica multivariada de componentes principais, em duas etapas. $\mathrm{Na}$ primeira, a seleção aconteceu dentro de cada grupo. Em seguida foi realizada uma análise conjunta para a seleção final. Foram adotados três critérios para descarte das variáveis. Foram descartados 34 descritores, uma redução de $64 \%$ dos descritores inicialmente considerados, e a lista mínima de descritores para o cupuaçuzeiro, ficou assim composta: CPF (comprimento do pecíolo foliar) ; ELF (espessura do limbo foliar); LAF (largura do acume foliar); ANB (angulação das nervuras de base); CBE (comprimento do botão estriado); CP (comprimento do pedúnculo floral); DP (diâmetro do pedúnculo floral); DO (diâmetro do ovário); NO (número de óvulos); CLP (comprimento da lâmina da pétala); CE (comprimento dos estaminóides); DTS (diâmetro transversal da semente); SC (semente chocha); AC (acidez); Brix; pH; BOTAO (número de botões caídos ao solo); FRUIMA (número de frutos imaturos caídos precocemente) e NV (número de vassouras-de-bruxa produzidas). A partir dos 19 descritores selecionados foi possível obter uma estimativa da variabilidade dos acessos do BAG de cupuaçuzeiro - Belém, pelo emprego da distância Euclideana média e agrupamento pelo método de Tocher e UPGMA. 


\section{Summary}

The objective of this work was to select morphological and agronomic quantitative descriptors to characteriza accessions of Theobroma grandiflorum (Willd. ex Spreng.) Schum. Fifty three descriptors were evaluated, including 14 from leaves; 18 from flowers; 16 from fruits; and 5 agronomic traits. To discard redundant or nondiscriminating descriptors, a two step multivariate analysis of principal components was applied. The first phase included the selection of descriptors within each group of characteristics individually (leaf; flower; fruit; agronomic). Based on the descriptors selected in this first phase, a joined analysis of principal componenets for the final selection. Three criteria were adopted for variable exclusion. Thirty four descriptors were excluded, reducing in $64 \%$ and a minimal list of descriptors for cupuassu was proposed, including: Leaf length (CPF); Leaf width (ELF); Leaf apex width (LAF); Leaf base vein angle (ANB); Flower bud length (CBE); Flower peduncle length (CP); Flower peduncle diameter (DP); Ovary girth (DO); Number of ovules (NO); Flower petal lamina length (CLP); Staminode length (CE); Seed width (DTS); Falt seeds (SC); Acidity (AC); Brix; pH; Number of fallen flowers buds (BOTAO); Number of abcised immature pods (FRUIMA); and Number of witches' brooms (NV). Based on the selected 19 descriptors, it was possible to estimate the variability of accession of the Cupuassu Germplasm Collection, Belém, using the average Euclidean distances and clustering by UPGMA and Tocher.

\subsection{Introdução}

O cupuaçuzeiro, Theobroma grandiflorum (Willd ex Spreng) Schum, que pertencia a família Sterculiaceae, atualmente está classificado dentro da família Malvaceae (Alverson et al., 1999). É uma das 22 espécies que compreende o gênero Theobroma, do qual o cacaueiro (Theobroma cacao L.) é a espécie economicamente mais importante. É uma fruteira tropical, de fecundação cruzada, diplóide $(2 n=20)$, que ocupa normalmente o subdossel da floresta Amazônica de terra firme. Trata-se de uma espécie pré-colombiana que, possivelmente, foi disseminada, de seu centro de origem, para todos os estados da Região Norte, inicialmente, através da intensa movimentação das nações indígenas no interior da Amazônia (Clement, 1999), e posteriormente, através do estabelecimento de pequenos cultivos em toda região. Hoje 
pode ser encontrado em vários estados brasileiros e também no exterior (Cavalcante, 1991).

Como toda espécie em fase inicial de domesticação, o cupuaçuzeiro apresenta, em condições de cultivo, baixa produtividade de frutos, em torno de 10 - 20 frutos árvore/ano, elevada desuniformidade intra e interpopulacional para todos os caracteres produtivos e, suscetibilidade à doença vassoura-de-bruxa (agente causal Crinipellis perniciosa), um dos grandes flagelos também do cacaueiro. O programa de melhoramento do cupuaçuzeiro visa minorar essas deficiências, tentando desenvolver cultivares com boa produtividade de frutos, e que agreguem a resistência a vassourade-bruxa. A variabilidade observada nas populações naturais, nas coleções de germoplasma e, até mesmo, nos plantios comerciais, apresenta grande potencial para aproveitamento pelo melhoramento, sendo que, genótipos relativamente próximos do ideótipo poderão ser identificados e selecionados diretamente dessas populações. Além da caracterização de cada acesso e de suas inter-relações, há necessidade da identificação de possíveis polimorfismos associados com as origens dos acessos, o que auxiliará no direcionamento de novas coletas. A manutenção da diversidade genética não é só um meio de salvaguardar contra a vulnerabilidade à doenças, pragas e estresses abióticos, porém assegura a continuidade do melhoramento genético (Bekele \& Bekele, 1996).

O Banco Ativo de Germoplasma do cupuaçuzeiro, localizado em Belém, Estado do Pará, com acessos oriundos dos estados do Pará, Amazonas e Amapá, têm por prioridade a caracterização e avaliação preliminar dos acessos, utilizando caracteres botânico-agronômicos (Figura 1) e resistência as doenças, para fornecer opções de atributos desejáveis para o programa de melhoramento, bem como, conservar parte da variabilidade existente ex situ. Para a caracterização do cupuaçuzeiro têm sido usado um número excessivo de variáveis, em função do completo desconhecimento sobre a importância de cada uma em descrever a variação existente. Muitas dessas variáveis são redundantes, por serem correlacionadas, ou dispensáveis, por representarem uma fração desprezível da variação total. Nestas circunstâncias, técnicas multivariadas são ferramentas eficientes na descrição e seleção de vários caracteres simultaneamente (Cruz, 1990). 

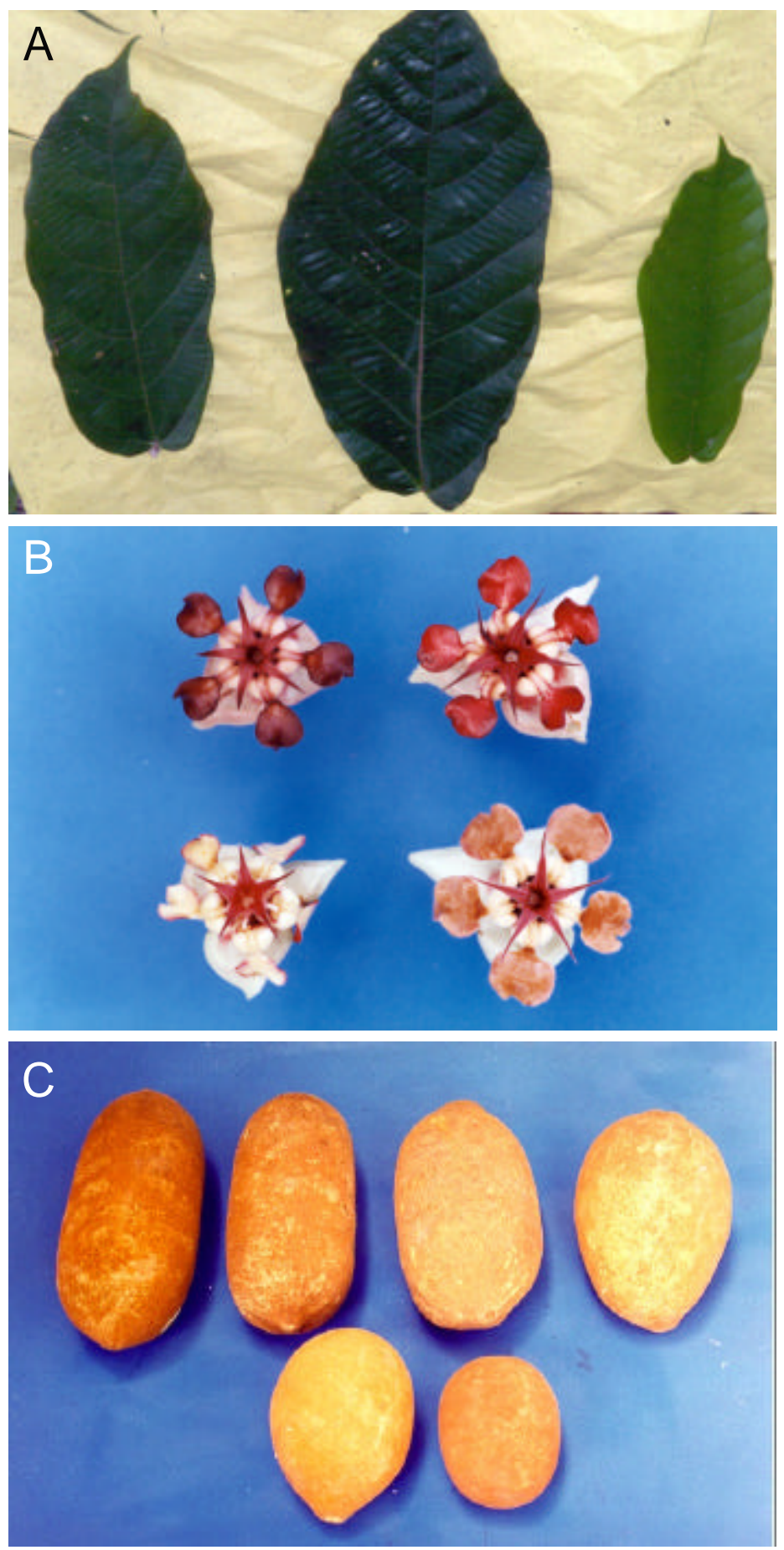

Figura 1 - Variabilidade em: A) Folha; B) Flor; C) Fruto de cupuaçuzeiro. 
A definição de uma lista de descritores botânico-agronômicos para o cupuaçuzeiro que fosse eficiente em discriminar os acessos, seria de grande valia para os melhoristas que ainda não dispõem de tecnologias mais avançadas, pois disponibilizaria uma metodologia acessível para definição de genitores ao programa de cruzamentos e identificação de erros de identificação de acessos nas coleções.

O presente trabalho teve como objetivos: i) definir uma lista mínima de descritores botânico-agronômicos para ser utilizada na caracterização fenética do cupuaçuzeiro; ii) caracterizar a variabilidade fenética existente dentro do Banco Ativo de Germoplasma de cupuaçuzeiro de Belém, mantido pela Embrapa Amazônia Oriental, utilizando dados botânico-agronômicos; iii) obter estimativas da diversidade fenética entre os acessos avaliados e classificar os acessos em grupos de similaridade fenética.

\subsection{Material e métodos}

\subsubsection{Material vegetal}

Foram analisados 31 acessos de cupuaçuzeiro (Tabela 1), coletados em pomares caseiros, pequenas propriedades rurais e áreas silvestres (Lima et al., 1986), nos Estados do Amazonas, Pará e Amapá. Estes materiais foram estabelecidos em 1985 no Banco Ativo de Germoplasma de cupuaçuzeiro (BAG), localizado em Belém, PA (128'S; 4827'W; 12,8 m de altitude), na forma de clones, sendo cinco plantas (rametes) representativas de cada clone, espaçadas de $6,0 \mathrm{~m} \times 5,0 \mathrm{~m}$ e tendo a espécie ingá (Inga edulis) como cobertura definitiva (Lima \& Costa, 1998).

\subsubsection{Descritores botânico-agronômicos}

Foram estudados 53 descritores, sendo 14 associados a características de folha; 18 à flor; 16 ao fruto; e 5 descritores agronômicos, detalhados a seguir (Tabela 2).

Os descritores de folha foram determinados pela coleta de folhas de três plantas de cada acesso, onde cada planta foi dividida em quatro quadrantes (Norte, Sul, Leste e Oeste), sendo que de cada quadrante foi escolhido um ramo, localizado na 
altura mediana da planta, de onde foram removidas três folhas, de número dois, quatro e oito, numeradas a partir da extremidade do ramo para a base. $O$ tamanho da amostra empregada foi $n=36$.

Na determinação dos descritores de flor foram escolhidas, em cada acesso, aleatoriamente, três plantas e, em cada planta três flores, totalizando nove flores por acesso e um total de 279 flores analisadas. Foram considerados caracteres de botão e de flor, sendo os botões avaliados no estádio de botão estriado, poucos minutos antes da antese, enquanto as flores, poucos minutos após a abertura total.

Tabela 1. Procedência dos acessos, origem populacional, localidade onde foram coletadas, e a numeração de introdução no BAG de cupuaçuzeiro - Belém, PA, 2002.

\begin{tabular}{|c|c|c|}
\hline População & Localidade & Acessos $^{1}$ \\
\hline \multicolumn{3}{|c|}{ Amazonas } \\
\hline & 1.1 - Tabatinga & 12 \\
\hline & 1.4- Tefé & 136,151 \\
\hline & $1.5-$ Coari & 174 \\
\hline & 1.6 - Anori & 181 \\
\hline & 1.7 - Codajás & $183,184,185,186$ \\
\hline & 1.8 - Manacapurú & 215,216 \\
\hline & 1.10 - Anamã & 219 \\
\hline & 1.11 - Cacau Pireira & 227 \\
\hline & 1.12 - Manaus & 228,229 \\
\hline & 1.13 - Itacoatiara & $247,248,1074$ \\
\hline \multicolumn{3}{|c|}{ Pará } \\
\hline & 2.1 - Belém & 286 \\
\hline & 2.2 - Muaná & 434,435 \\
\hline & 2.3 - Gurupá & 554 \\
\hline & 2.4 - Santarém & $618,620,624$ \\
\hline & 2.5 - Alenquer & 623 \\
\hline & 2.6 - Prainha & 622 \\
\hline \multicolumn{3}{|c|}{ Amapá } \\
\hline & 3.1-Rio Urucauá & 512,513 \\
\hline & 3.2 - Rio Curipí & 514,516 \\
\hline
\end{tabular}

Fonte: Adaptado de Lima et al. (1986)

$\left.{ }^{1}\right)$ Número de entrada do acesso na coleção. 
$\mathrm{Na}$ determinação dos descritores de fruto cada um dos acessos foi representado, aleatoriamente, por três plantas e de cada planta foram estudados cinco frutos $(n=15)$. Após colhidos, os frutos eram levados para o laboratório onde os caracteres foram avaliados. $\mathrm{Na}$ avaliação dos caracteres bromatológicos da polpa, foram retiradas amostras de $20 \mathrm{~g}$ de polpa de cada fruto estudado, e enviadas para 0 Laboratório de Agroindústria da Embrapa Amazônia Oriental, onde foram medidos brix, acidez, umidade e pH, conforme citado por Alves et. al. (1998c). O Brix foi determinado por refratometria, através de refratômetro modelo ATAGO PR-101. A acidez total, expressa em porcentagem de ácido cítrico foi determinada por titulometria, através de uma solução de $\mathrm{NaOH}$ a $0,1 \mathrm{~N}$. O pH, foi determinado em pH-metro modelo Horiba F21. Na determinação da umidade, as amostras foram secas em estufa, a $105^{\circ} \mathrm{C}$, até atingir peso constante.

As avaliações de todas as variáveis agronômicas foram realizadas durante o período de cinco anos (de 1996 a 2001). A totalização dos dados dos descritores agronômicos foi feita ao final de cada ano agrícola. Cada acesso estava representado por cinco plantas $(n=25)$. A avaliação de produção de frutos foi realizada através de contagem dos frutos maduros, mensalmente, durante o período da safra. A produção de botões, flores e frutos imaturos foram avaliados semanalmente, no período de floração e frutificação. Para a coleta desses dados, a região de projeção da copa das plantas foi forrada com plástico, para facilitar a visualização dos botões, flores e frutos imaturos caídos. As variáveis referentes a produção de botão, flor e fruto imaturo foram agrupadas no conjunto de descritores agronômicos por estarem intimamente integradas ao esforço reprodutivo dos acessos. O número de vasouras verdes que surgiam em cada planta eram contadas a cada quinze dias. 
Tabela 2. Caracteres botânico-agronômicos avaliados no BAG de cupuaçuzeiro.

\begin{tabular}{|c|c|}
\hline Sigla & $\begin{array}{l}\text { Descrição dos Caracteres } \\
\text { Descritores de Folha: }\end{array}$ \\
\hline CF & Comprimento Foliar, da base ao ápice do limbo foliar $(\mathrm{cm})[n=36]$; \\
\hline LLBASE & Largura do limbo foliar, na base $(\mathrm{cm})[\mathrm{n}=36]$ \\
\hline LLMEIO & Largura do limbo foliar, no meio $(\mathrm{cm})[\mathrm{n}=36]$; \\
\hline LLTOPO & Largura do limbo foliar, no topo $(\mathrm{cm})[\mathrm{n}=36]$ \\
\hline CPF & Comprimento do pecíolo foliar $(\mathrm{cm})[\mathrm{n}=36]$; \\
\hline DPF & Diâmetro do pecíolo foliar, na porção média $(\mathrm{cm})[\mathrm{n}=36]$; \\
\hline EL & Espessura do limbo, na porção média $(\mu \mathrm{m})[\mathrm{n}=36]$ \\
\hline $\mathrm{CA}$ & Comprimento da base à extremidade do ácume $(\mathrm{cm})[\mathrm{n}=36]$; \\
\hline LA & Largura do ácume, na porção média $(\mathrm{cm})[\mathrm{n}=36]$; \\
\hline ANB & Angulação das nervuras da base $(\mathrm{cm})[\mathrm{n}=36]$; \\
\hline ANM & Angulação das nervuras do meio $(\mathrm{cm})[\mathrm{n}=36]$; \\
\hline ANT & Angulação das nervuras do topo $(\mathrm{cm})[\mathrm{n}=36]$; \\
\hline DN & Distância entre nervuras $(\mathrm{cm})[\mathrm{n}=36]$; \\
\hline NPN & $\begin{array}{r}\text { Número de pares de nervuras }(\mathrm{cm})[\mathrm{n}=36] ; \\
\text { Descritores de flor: }\end{array}$ \\
\hline CBE & Comprimento da base ao topo do botão estriado $(\mathrm{mm})[\mathrm{n}=9]$ \\
\hline DBE & Diâmetro botão estriado, na porção média $(\mathrm{mm})[\mathrm{n}=9]$; \\
\hline TFL & Tamanho da flor, diâmetro da flor aberta $(\mathrm{mm})[\mathrm{n}=9]$ \\
\hline CLS & Comprimento da lâmina da sépala $(\mathrm{mm})[\mathrm{n}=45]$; \\
\hline LLS & Largura da lâmina da sépala, na porção média $(\mathrm{mm})[\mathrm{n}=45]$; \\
\hline CLP & Comprimento da lâmina da pétala $(\mathrm{mm})[\mathrm{n}=45]$; \\
\hline LLP & Largura da lâmina da pétala, na porção média $(\mathrm{mm})[\mathrm{n}=45]$; \\
\hline $\mathrm{CC}$ & Comprimento da cucula na porção média $(\mathrm{mm})[\mathrm{n}=45]$ \\
\hline LC & Largura da cucula, na porção média $(\mathrm{mm})[\mathrm{n}=45]$; \\
\hline CE & Comprimento dos estaminóides $(\mathrm{mm})[\mathrm{n}=45]$ \\
\hline DEA & Distância entre estigma e anteras $(\mathrm{mm})[\mathrm{n}=9]$; \\
\hline $\mathrm{CP}$ & Comprimento do pedúnculo $(\mathrm{mm})[\mathrm{n}=9]$; \\
\hline DP & Diâmetro do pedúnculo, na porção média $(\mathrm{mm})[\mathrm{n}=9]$; \\
\hline CES & Comprimento do estilete $(\mathrm{mm})[\mathrm{n}=9]$; \\
\hline $\mathrm{CO}$ & Comprimento do ovário $(\mathrm{mm})[\mathrm{n}=9]$ \\
\hline DO & Diâmetro do ovário, na porção média $(\mathrm{mm})[\mathrm{n}=9]$; \\
\hline NO & Número de óvulos [n = 9]; \\
\hline VGP & $\begin{array}{r}\text { Viabilidade de grãos de pólen (\%) }[\mathrm{n}=9] ; \\
\text { Descritores de fruto: }\end{array}$ \\
\hline DL & Diâmetro longitudinal do fruto $(\mathrm{mm})[\mathrm{n}=15]$; \\
\hline DT & Diâmetro transversal do fruto, na porção média $(\mathrm{mm})[\mathrm{n}=15]$; \\
\hline PFR & Peso do fruto $(g)[n=15]$ \\
\hline PCA & Peso da casca do fruto $(\mathrm{g})[\mathrm{n}=15]$ \\
\hline PPO & Peso da polpa (g) [n=15]; \\
\hline ECA & Espessura da casca $(\mathrm{mm})[\mathrm{n}=15]$ \\
\hline ES & Espessura da semente $(\mathrm{mm})[\mathrm{n}=15]$ \\
\hline DLS & Diâmetro longitudinal da semente $(\mathrm{mm})[\mathrm{n}=15]$; \\
\hline DTS & Diâmetro transversal da semente $(\mathrm{mm})[\mathrm{n}=15]$; \\
\hline SN & Número de sementes normais [ $n=15]$; \\
\hline SC & Número de sementes abortadas, chochas [ $n=15]$; \\
\hline $\mathrm{AC}$ & Teor de acidez $[n=15]$ \\
\hline BRIX & Teor de Brix $\left({ }^{\circ}\right)[n=15]$; \\
\hline $\mathrm{PH}$ & Medida do $\mathrm{pH}[\mathrm{n}=15]$ \\
\hline UM & $\begin{array}{r}\text { Teor de umidade }(\%)[n=15] ; \\
\text { Descritores agronômicos: }\end{array}$ \\
\hline PROD & Número de frutos maduros $[\mathrm{n}=25]$ \\
\hline BOTAO & Número de botões caídos ao solo [ $\mathrm{n}=25]$; \\
\hline FLOR & Número de flores caídas ao solo [ $\mathrm{n}=25]$; \\
\hline FRUIMA & Número de frutos imaturos caídos precocemente $[n=25]$; \\
\hline NV & Número de vassouras-de-bruxa produzidas [n=25]. \\
\hline
\end{tabular}




\subsubsection{Metodologias estatísticas}

Para cada descritor botânico e agronômico foi realizada a análise de variância para estimar o poder discriminatório dos caracteres e o erro experimental. Foi empregado o delineamento inteiramente casualizado com 31 tratamentos (acessos) e três a cinco repetições, para os descritores botânicos e agronômicos, respectivamente. Cada planta representou uma repetição e cada observação foi obtida com a média das medidas tomadas do descritor. Dados de contagem e percentagem foram transformados pela raiz quadrada e pelo arco seno raiz quadrada, respectivamente, para que os resíduos apresentassem distribuição normal.

Foi empregado o método de análise multivariada por componentes principais (SAS INSTITUTE, 1989) para descartar variáveis com pouca influência na discriminação dos materiais estudados (Cruz \& Regazzi, 1997; Strapasson, 1997). Inicialmente, foram realizadas quatro análises de componentes principais, uma para cada conjunto de descritores (folha, flor, fruto e agronômicas), conforme sugerido por Strapasson (1997), devido o número de acessos (31 clones) ser inferior ao número de descritores (53 variáveis). Foi procedido o primeiro descarte de variáveis dentro de cada conjunto, onde, provavelmente, as variáveis deveriam estar mais fortemente correlacionadas. As variáveis pré-selecionados foram re-analisadas conjuntamente, e então procedida uma última análise, para o descarte final das variáveis.

Como o procedimento de descarte baseado apenas em componentes principais pode ser drástico (Daher, 1993), foram adotados três métodos para descarte das variáveis: i) era indicada para descarte a variável de maior autovalor, em cada componente, sempre que ele era inferior a 0,7 (método I) (Jollife, 1972, 1973; Mardia et al., 1979; ii), à cada carater descartado foi realizada uma nova análise com os caracteres remanescentes (método II) (Cury, 1993; Dias, 1994); iii) Somente foram efetivamente descartadas, as variáveis apontadas para descarte pelos dois métodos, indicando consistênciadas metodologias.

Na determinação do grau de associação entre todos os descritores estudados, foram estimados os coeficientes de correlação de Pearson, estimando-se inicialmente 
as covariâncias individuais entre pares de caracteres, baseado no modelo de Cruz e Regazzi (1997).

\subsubsection{Divergência fenética}

Para obtenção das estimativas de dissimilaridade fenética entre os acessos (GENES, 1997), baseadas nas variáveis botânico-agronômicas, foi empregada a distância Euclideana média (dii'), para contornar o problema da influência do número de caracteres (Cruz \& Regazzi, 1997). Os dados foram padronizados para eliminar o problema de escala, e visando obter uma síntese dos resultados e comparar os padrões de agrupamentos produzidos pelos dois tipos de métodos, foram utilizados 0 método de otimização de Tocher (Rao, 1952) e o método hierárquico de ligação média não ponderada (UPGMA) (STATSOFT,1996).

\subsubsection{Concordância entre a caracterização genética e fenotípica}

Foi estimada a concordância entre os métodos de estimação das distâncias genéticas e fenotípicas de 31 acessos do Banco Ativo de Germoplasma de cupuaçuzeiro, com base em 21 marcadores microssatélites e 19 descritores botânicoagronômicos (Capítulo 3). A significância dessa correlação também foi testada pela estatística $z$ de Mantel, usando 5.000 permutações, no programa TFPGA (Miller, 1997).

\subsection{Resultados e discussão}

\subsubsection{Seleção dentro de grupos de descritores}

O teste $F$ acusou diferenças altamente significativas entre os acessos para quase todas as variáveis dos quatro conjuntos, exceto para CPF (comprimento do pecíolo foliar) e SN (sementes normais), que foram apenas significativas, e duas variáveis de fruto que não foram significativas. Os acessos poderiam ser separados em dois ou mais grupos, o que foi confirmado pelo teste de Tukey (Anexo E).

Os valores do coeficiente de determinação $\left(R^{2}\right)$ para a maioria dos caracteres foram superiores a 0,5 reforçando a confiabilidade desses descritores. Quanto ao coeficiente de variação (CV) os grupos de descritores tiveram comportamento distintos. Os coeficientes de variação para as variáveis de flor foram menores que os 
observados para os caracteres de folha, sugerindo que os caracteres de flor seriam menos afetados pelo ambiente e, portanto, possivelmente mais discriminativos. Porém, dos caracteres botânicos estudados, as variáveis de fruto foram os que apresentaram os maiores valores de coeficiente de variação, contrastando com as variáveis de flor e, até mesmo com as variáveis de folha, que apresentaram menores estimativas, demonstrando que foram os mais influenciados pelas condições ambientais.

As estimativas das variâncias dos componentes principais (autovalores) e a porcentagem acumulada dessas estimativas, obtidas a partir de cada conjunto de descritores (folha, flor, fruto e agronômicos) encontram-se nas Tabela 3. Para esses quatro conjuntos de descritores, os dois primeiros componente principais retiveram cerca de $67 \%$, 54\%, 58\% e 74\%, repectivamente, de toda a variação disponível. Por sua vez, os quatro primeiros componentes (em que $\lambda_{j}>0,7$ ) já respondiam por cerca de $87 \%, 72 \%, 77 \%$ e $97 \%$ dessa variação, demonstrando que os primeiros componentes praticamente explicavam grande parte da variação existente no Banco de Germoplasma e, o método de descarte deveria ser eficiente. Dentro dos grupos de descritores a diluição dessa variação foi maior a medida que aumentava o número de descritores analisados. Esse efeito já foi descrito para mandioca (Pereira, 1989; Cury, 1993); capim elefante (Daher, 1993; Strapasson, 1997); cajú (Barros, 1991); e cacau (Dias, 1994).

Seguindo o método de descarte estabelecido, foram eliminadas sete variáveis de folha (50\%), oito de flor (44\%), sete de fruto (44\%) e duas agronômica (40\%).

As estimativas de correlação de Pearson entre o grupo de variáveis descartadas e o grupo das selecionadas indicam que as eliminações não ocasionaram perda significativa de informação (Tabela 4). Pode ser observado que cada variável descartada encontrava-se altamente correlacionada com pelo menos uma variável que foi selecionada. Entre os descritores de fruto, as variáveis PFR (peso de fruto), PPO (peso de polpa) e PSE (peso das sementes), consideradas como de maior relevância para os programas de melhoramento, foram eliminadas nessa primeira fase de descarte, possivelmente porque encontravam-se fortemente correlacionadas com 0 
Tabela 3. Estimativas das variâncias (autovalor $\lambda_{\mathrm{j}}$ ), porcentagem acumulada de 14 descritores de folha, flor, fruto e agronômicos de cupuaçuzeiro, avaliados em 31 acessos do BAG de cupuaçuzeiro.

\begin{tabular}{|c|c|c|c|}
\hline \multicolumn{2}{|l|}{ Componentes } & \multirow{2}{*}{$\begin{array}{c}\text { Variâncias dos } \\
\text { Componentes }\left(\lambda_{\mathrm{j}}\right) \\
6,9749\end{array}$} & \multirow{2}{*}{$\begin{array}{c}\begin{array}{c}\text { Porcentagens } \\
\text { Acumuladas (\%) }\end{array} \\
0,4982\end{array}$} \\
\hline Folha: & 1 & & \\
\hline & 2 & 2,3569 & 0,6665 \\
\hline & 3 & 1,8219 & 0,7967 \\
\hline & 4 & 1,0409 & 0,8710 \\
\hline & 5 & 0,6168 & 0,9151 \\
\hline & 6 & 0,4698 & 0,9486 \\
\hline & 7 & 0,2374 & 0,9656 \\
\hline & 8 & 0,1879 & 0,9790 \\
\hline & 9 & 0,1548 & 0,9901 \\
\hline & 10 & 0,0640 & 0,9947 \\
\hline & 11 & 0,0351 & 0,9972 \\
\hline & 12 & 0,0256 & 0,9990 \\
\hline & 13 & 0,0117 & 0,9998 \\
\hline & 14 & 0,0018 & 1 \\
\hline \multirow[t]{18}{*}{ Flor: } & 1 & 6,9986 & 0,3888 \\
\hline & 2 & 2,6565 & 0,5364 \\
\hline & 3 & 1,8133 & 0,6371 \\
\hline & 4 & 1,5267 & 0,7219 \\
\hline & 5 & 1,2078 & 0,7890 \\
\hline & 6 & 0,8482 & 0,8361 \\
\hline & 7 & 0,6916 & 0,8746 \\
\hline & 8 & 0,6186 & 0,9089 \\
\hline & 9 & 0,3816 & 0,9301 \\
\hline & 10 & 0,3709 & 0,9507 \\
\hline & 11 & 0,2788 & 0,9662 \\
\hline & 12 & 0,1540 & 0,9748 \\
\hline & 13 & 0,1437 & 0,9828 \\
\hline & 14 & 0,1096 & 0,9889 \\
\hline & 15 & 0,1048 & 0,9947 \\
\hline & 16 & 0,0490 & 0,9974 \\
\hline & 17 & 0,0328 & 0,9992 \\
\hline & 18 & 0,0129 & 1 \\
\hline \multirow{16}{*}{ Fruto: } & 1 & 6,7001 & 0,4187 \\
\hline & 2 & 2,6506 & 0,5844 \\
\hline & 3 & 1,7722 & 0,6951 \\
\hline & 4 & 1,1756 & 0,7686 \\
\hline & 5 & 1,0433 & 0,8338 \\
\hline & 6 & 0,8134 & 0,8847 \\
\hline & 7 & 0,6439 & 0,9249 \\
\hline & 8 & 0,3576 & 0,9473 \\
\hline & 9 & 0,3448 & 0,9688 \\
\hline & 10 & 0,1870 & 0,9805 \\
\hline & 11 & 0,1455 & 0,9896 \\
\hline & 12 & 0,0841 & 0,9949 \\
\hline & 13 & 0,0391 & 0,9973 \\
\hline & 14 & 0,0297 & 0,9992 \\
\hline & 15 & 0,0108 & 0,9999 \\
\hline & 16 & 0,0016 & 1 \\
\hline \multirow{5}{*}{ Agronômicos: } & 1 & 2,3699 & 0,4740 \\
\hline & 2 & 1,3433 & 0,7426 \\
\hline & 3 & 0,8589 & 0,9144 \\
\hline & 4 & 0,2908 & 0,9726 \\
\hline & 5 & 0,1368 & 1 \\
\hline
\end{tabular}


DL (diâmetro longitudinal do fruto), PCA (peso da casca) e DTS (diâmetro transversal das sementes), mantidas pela seleção. Merece destaque, entre os descritores agronômicos, o fato de não haver correlação entre as variáveis PROD (produção de frutos) e NV (número de vassouras-de-bruxa produzidas na planta), sugerindo que não existe relação entre maior ou menor capacidade produtiva e susceptibilidade a doença vassoura-de-bruxa, por se tratar de caracteres independentes, o que facilita a obtenção de indivíduos altamente produtivos e ao mesmo tempo resistentes (Tabela 4).

A análise de correlação dentro do grupo das variáveis selecionadas, revelou o efeito discriminativo provocado pelo descarte das variáveis redundantes, com 0 drástico decréscimo do número de correlações significativas e altamente significativas. Estes resultados indicaram que o método de descarte das variáveis empregadas foi eficiente na identificação e descarte das variáveis redundantes, e que as eliminações não ocasionaram perda significativa de informação.

Após a seleção das variáveis, foi verificada a eficiência do descarte, levandose em conta, além do método misto, os dois métodos auxiliares, métodos I e II, que serviram de base para o método empregado nesta pesquisa. Para tanto foram utilizados os três critérios propostos por Jolliffe (1973), para avaliar a correlação entre componentes principais de conjuntos completos e reduzido. O primeiro leva em consideração os valores nominais dos coeficientes de correlação $r_{1}$ e $Q_{1}$; o segundo verifica se os componentes reduzidos são mesclas dos componentes completos e, finalmente, o terceiro avalia se a ordenação dos componentes reduzidos obedece a mesma ordenação dos componentes originais.

Os Métodos I e II selecionaram quatro variáveis cada, com uma única variável coincidente $(E L)$, as quais foram agrupadas em sete variáveis pelo método misto (Tabela 5). Os métodos I e misto apresentaram valores de $r_{1}$ e Q1 elevados e muito semelhantes, superiores aos observados pelo método II. O método misto, entretanto, apresentou uma ordenação perfeita entre os componentes do conjunto reduzido, sem apresentar nenhuma mescla, indicativo de perfeita correlação com o conjunto original, fato que não ocorreu com os outros dois métodos, isoladamente. 
Tabela 4. Estimativas dos coeficientes de correlação de Pearson, entre os descritores de folha, flor, fruto e agronômicos, selecionados (horizontal) e descartados (vertical), avaliados em 31 acessos do BAG de cupuaçuzeiro, Belém-PA, 2002.

\begin{tabular}{lccccccc}
\hline Descritores & \multicolumn{7}{c}{ Descritores Seleccionados: Folha } \\
\cline { 2 - 8 } Descartados & LLTOPO & CPF & EL & CA & LA & ANB & DN \\
\hline CF & $0,74^{* *}$ & $0,54^{* *}$ & $-0,19$ & $0,40^{*}$ & 0,03 & $-0,16$ & 0,28 \\
LLBASE & $0,94^{* *}$ & $0,46^{* *}$ & $-0,07$ & 0,29 & $-0,14$ & $-0,58^{* *}$ & $-0,12$ \\
LLMEIO & $0,97^{\star *}$ & $0,48^{* *}$ & 0,00 & $0,36^{*}$ & $-0,17$ & $-0,55^{* *}$ & $-0,13$ \\
DP & $0,78^{\star *}$ & $0,62^{* *}$ & 0,20 & $0,60^{\star *}$ & $-0,36^{*}$ & $-0,34$ & $-0,24$ \\
ANM & $-0,62^{* *}$ & $-0,15$ & 0,09 & $-0,02$ & 0,32 & $0,78^{* *}$ & $0,66^{* *}$ \\
ANT & $-0,60^{* *}$ & $-0,29$ & 0,19 & $-0,12$ & $0,44^{*}$ & $0,59^{* *}$ & $0,67^{* *}$ \\
NPN & $0,74^{* *}$ & $0,55^{* *}$ & 0,18 & $0,67^{* *}$ & $-0,37^{*}$ & $-0,33$ & $-0,31$ \\
\hline
\end{tabular}

\begin{tabular}{lcccccccccc}
\hline Descritores & \multicolumn{10}{c}{ Descritores Selecionados: Flor } \\
\cline { 2 - 11 } Descartados & CBE & TFL & CP & DP & CES & DO & NO & VGP & CLP & CE \\
\hline DBE & $0,74^{* *}$ & $0,44^{*}$ & $0,37^{*}$ & $-0,05$ & 0,28 & 0,19 & $-0,05$ & $0,43^{*}$ & 0,35 & 0,23 \\
DEA & 0,20 & $0,47^{* *}$ & 0,16 & 0,03 & $0,41^{*}$ & $0,50^{* *}$ & 0,06 & $-0,01$ & $0,41^{*}$ & $0,77^{* *}$ \\
CO & 0,01 & 0,30 & 0,15 & $-0,08$ & $0,60^{* *}$ & $0,80^{* *}$ & 0,30 & $-0,06$ & 0,12 & $0,60^{* *}$ \\
CLS & $0,83^{* *}$ & $0,66^{* *}$ & 0,10 & 0,03 & 0,21 & 0,28 & 0,09 & 0,09 & $0,48^{\star *}$ & $0,53^{* *}$ \\
LLS & $0,47^{* *}$ & $0,58^{* *}$ & 0,32 & 0,00 & $0,38^{*}$ & $0,38^{*}$ & $-0,15$ & $0,39^{*}$ & $0,47^{* *}$ & $0,45^{* *}$ \\
LLP & $0,45^{*}$ & $0,45^{* *}$ & 0,30 & $-0,21$ & 0,05 & 0,27 & $-0,11$ & 0,27 & $0,79^{\star *}$ & 0,29 \\
CC & 0,29 & $0,50^{* *}$ & 0,13 & 0,10 & $0,48^{* *}$ & 0,34 & 0,04 & 0,21 & 0,32 & $0,73^{* *}$ \\
LC & 0,09 & $0,57^{* *}$ & 0,08 & 0,12 & $0,38^{*}$ & $0,43^{*}$ & $-0,03$ & 0,15 & 0,32 & $0,80^{* *}$ \\
\hline
\end{tabular}

\begin{tabular}{cccccccccc}
\hline Descritores & \multicolumn{8}{c}{ Descritores Selecionados: Fruto: } \\
\cline { 2 - 9 } Descartados & DL & PCA & ECA & DTS & SN & SC & AC & BRIX & PH \\
\hline DT & $0,38^{*}$ & $0,73^{* *}$ & $-0,31$ & $0,49^{* *}$ & $0,40^{*}$ & $-0,11$ & 0,13 & $-0,31$ & 0,26 \\
PFR & $0,80^{* *}$ & $0,91^{* *}$ & $-0,31$ & $0,47^{* *}$ & $0,39^{*}$ & $-0,22$ & $-0,06$ & $-0,18$ & 0,29 \\
PPO & $0,72^{* *}$ & $0,80^{* *}$ & $-0,34$ & $0,51^{* *}$ & 0,35 & $-0,12$ & 0,02 & $-0,25$ & 0,30 \\
PSE & $0,58^{* *}$ & $0,52^{* *}$ & $-0,43^{*}$ & $0,75^{* *}$ & $0,69^{* *}$ & $-0,22$ & 0,30 & 0,11 & 0,06 \\
ES & $0,82^{* *}$ & $0,72^{* *}$ & $-0,32$ & $0,55^{* *}$ & 0,29 & $-0,42^{*}$ & $-0,14$ & 0,07 & 0,06 \\
DLS & $0,37^{*}$ & $0,35^{*}$ & $-0,47^{* *}$ & $0,81^{* *}$ & 0,20 & $-0,01$ & 0,17 & 0,04 & $-0,04$ \\
UM & 0,07 & 0,34 & 0,00 & $-0,16$ & $-0,12$ & 0,05 & $-0,42^{*}$ & $-0,72^{* *}$ & 0,09 \\
\hline
\end{tabular}

\begin{tabular}{cccc}
\hline Descritores & \multicolumn{3}{c}{ Descritores Selecionados: Agronômicos } \\
\cline { 2 - 4 } Descartados & BOTAO & FRUIMA & NV \\
\hline PROD & 0,32 & $0,57^{\star *}$ & $-0,17$ \\
FLOR & $0,83^{\star *}$ & 0,06 & $-0,33$ \\
\hline
\end{tabular}


No método I o segundo componente reduzido é uma mescla do primeiro e segundo componentes originais, assim também, o terceiro é uma mescla do terceiro e quarto componentes originais. No método II o primeiro componente do conjunto selecionado é uma mescla do primeiro e terceiro componente do conjunto completo, assim como, o terceiro é uma mescla do segundo e quarto componentes originais. Em razão do exposto foram selecionadas as variáveis agrupadas pelo método misto: LLTOPO (largura do limbo no topo), CPF (comprimento do pecíolo foliar), EL (espessura do limbo), CA (comprimento do ácume), LA (largura do ácume), ANB (angulação das nervuras de base) e DN (distância entre nervuras).

Foi possível observar que os Métodos I e II selecionaram sete variáveis cada, com uma taxa de coincidência de $57 \%$, bem superior ao observado para os descritores de folha, quando o resultado comparativo dos dois métodos foi muito discrepante. Estas variáveis foram agrupadas pelo método misto, resultando em 10 variáveis, que representou uma taxa de seleção de 55,6\% em relação as 18 variáveis iniciais. Esta taxa foi muito similar a obtida para o conjunto de caracteres de folha. Os métodos II e misto apresentaram valores de $r_{1}$ e $Q_{1}$ elevados e muito similares, e, somente, ligeiramente superiores aos observados pelo método I. Os métodos apresentaram ligeiras trocas na ordem dos componentes reduzidos. O método misto, por exemplo, alterou a ordem do sétimo pelo oitavo, e do nono pelo décimo componente. Seu segundo componente reduzido é uma mescla do segundo e terceiro componentes originais. No método I o segundo componente reduzido é uma mescla do terceiro e quarto componentes originais e, no método II, o quinto componente reduzido é uma mescla do quinto e sétimo componentes originais. Apesar da eficiência similar de todos os métodos aqui apresentados, foi mantida a seleção conservativa do método misto, visto que as variáveis ainda passariam por uma nova etapa de seleção. Foram então selecionados CBE (comprimento do botão estriado), TFL (tamanho da flor), CP (comprimento do pedúnculo), DP (diâmetro do pedúnculo), CES (comprimento do estilete), DO (diâmetro do ovário), NO (número de óvulos), VGP (viabilidade de grãos de pólen), CLP (comprimento da lâmina da pétala) e CE (comprimento dos estaminóides). 
Em relação aos descritores de fruto, seis variáveis foram selecionadas pelos métodos I e II cada um, sendo que a taxa de coincidência das variáveis selecionadas, pelos dois métodos, foi de $33 \%$, inferior ao obtido para as variáveis de flor $(57 \%)$, porém um pouco superior ao que foi observado para as variáveis de folha (25\%). Estas variáveis foram agrupadas pelo método misto resultando em nove variáveis, que representou uma taxa de seleção de 56,25\%, em relação as 16 variáveis iniciais. Esta taxa foi muito similar a obtida para os conjuntos de caracteres de flor e folha. À semelhança do que foi observado para as variáveis de folha, as estimativas dos valores $r_{1}$ e $Q_{1}$ foram elevadas e muito similares entre os métodos I e misto, superiores aos observados pelo método II. A grande diferença entre os métodos I e misto, foi que o método misto mostrou uma perfeita ordenação dos componentes reduzidos em relação aos componentes originais, sem presença de nenhuma mescla, fato que também foi observado para as variáveis de folha. O método I, apesar de apresentar magnitude dos coeficientes de similaridade ligeiramente superiores ao método misto, apresentou trocas na ordem dos componentes reduzidos, e duas mesclas. Assim, mantida a seleção pelo método misto, foram selecionadas as variáveis de fruto $D L$ (diâmetro longitudinal), PCA (peso da casca), ECA (espessura da casca) -, DTS (diâmetro transversal das sementes), SN (sementes normais), SC (sementes chochas), $\mathrm{AC}$ (acidez), BRIX (Brix) e PH (pH).

Para os descritores agronômicos, houve uma coincidência perfeita entre os três métodos de descarte sobre quais variáveis deveriam ser eliminadas, reforçando a confiabilidade da seleção (Tabela 5). As estimativas dos valores $r_{1}$ e $Q_{1}$ foram elevadas, com perfeita ordenação dos componentes reduzidos em relação aos componentes originais. Esta situação somente foi observada no presente trabalho para as variáveis de folha e fruto com utilização do método misto. Foram selecionadas as variáveis Número de Botões - BOTAO, Número de Frutos Imaturos - FRUIMA e Número de Vassouras-de-bruxa - NV, que correspondem a $60 \%$ de seleção em relação as cinco variáveis iniciais, taxa esta ligeiramente superior aos caracteres botânicos. 
Tabela 5. Estimativas de medidas de similaridade, $r_{1}(j)$ e $Q_{1}$, entre componentes principais nos conjuntos completo e reduzido dos descritores de folha, flor, fruto e agronômicos, no BAG de cupuaçuzeiro, Belém-PA, 2002.

\begin{tabular}{|c|c|c|c|}
\hline \multirow{3}{*}{$\begin{array}{l}\text { Medidas de } \\
\text { Similaridade: } \\
\text { Folha }\end{array}$} & \multicolumn{3}{|c|}{ Descritores selecionados } \\
\hline & Método I & Método II & Método Mixto \\
\hline & LLTOPO, EL, CA, DN & CPF, EL, LA, ANB & $\begin{array}{c}\text { LLTOPO, CPF, EL, CA, } \\
\text { LA, ANB, DN }\end{array}$ \\
\hline$r_{1}(1)$ & $0,9683(2)$ & $0,7096(1)$ & $0,9404(1)$ \\
\hline$r_{1}(2)$ & $0,8352(2)$ & $0,9742(3)$ & $0,7823(2)$ \\
\hline$r_{1}(3)$ & $0,8869(3)$ & $0,7947(1)$ & $0,8241(3)$ \\
\hline$r_{1}(4)$ & $0,8964(3)$ & $0,8494(3)$ & $0,9688(4)$ \\
\hline$r_{1}(5)$ & - & - & $0,9165(5)$ \\
\hline$r_{1}(6)$ & - & - & $0,7562(6)$ \\
\hline$r_{1}(7)$ & - & 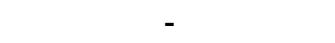 & $0,8209(7)$ \\
\hline $\mathrm{Q}_{1}$ & 0,9243 & 0,7854 & 0,8897 \\
\hline $\begin{array}{l}\text { Medidas de } \\
\text { Similaridade: } \\
\text { Flor }\end{array}$ & $\begin{array}{l}\text { CBE, CP, DP, DO, } \\
\text { NO, CLP, CE }\end{array}$ & $\begin{array}{c}\text { CBE, TFL, DP, CES, } \\
\text { DO, VGP, CLP }\end{array}$ & $\begin{array}{l}\text { CBE, TFL, CP, DP, } \\
\text { CES, DO, NO, VGP, } \\
\text { CLP, CE }\end{array}$ \\
\hline$r_{1}(1)$ & $0,8747(1)$ & $0,9690(1)$ & $0,9612(1)$ \\
\hline$r_{1}(2)$ & $0,8120(3)$ & $0,7418(2)$ & $0,7405(2)$ \\
\hline$r_{1}(3)$ & $0,6629(2)$ & $0,7246(4)$ & $0,7956(2)$ \\
\hline$r_{1}(4)$ & $0,6965(2)$ & $0,8475(3)$ & $0,9700(4)$ \\
\hline$r_{1}(5)$ & $0,7854(6)$ & $0,7126(5)$ & $0,8656(5)$ \\
\hline$r_{1}(6)$ & $0,8375(5)$ & $0,5067(6)$ & $0,7353(6)$ \\
\hline$r_{1}(7)$ & $0,7202(7)$ & $0,6992(5)$ & $0,5623(8)$ \\
\hline$r_{1}(8)$ & - & - & $0,6786(7)$ \\
\hline$r_{1}(9)$ & - & - & $0,6677(10)$ \\
\hline$r_{1}(10)$ & - & - & $0,5685(9)$ \\
\hline $\mathrm{Q}_{1}$ & 0,8068 & 0,8343 & 0,8508 \\
\hline
\end{tabular}

\begin{tabular}{cccc}
$\begin{array}{c}\text { Medidas de } \\
\text { Similaridade: }\end{array}$ & $\begin{array}{c}\text { DL, PCA, ECA, DTS, } \\
\text { SN, AC }\end{array}$ & $\begin{array}{c}\text { ECA, DTS, SN, SC, } \\
\text { BRIX, PH }\end{array}$ & $\begin{array}{c}\text { DL, PCA, ECA, DTS, } \\
\text { SN, SC, AC, BRIX, PH }\end{array}$ \\
Fruto & & & $0,9708(1)$ \\
\hline$r_{1}(1)$ & $0,9898(1)$ & $0,7899(1)$ & $0,9596(2)$ \\
$r_{1}(2)$ & $0,9865(2)$ & $0,8820(1)$ & $0,8489(3)$ \\
$r_{1}(3)$ & $0,8876(2)$ & $0,8643(2)$ & $0,8471(4)$ \\
$r_{1}(4)$ & $0,7051(5)$ & $0,7958(3)$ & $0,7993(5)$ \\
$r_{1}(5)$ & $0,9286(3)$ & $0,8473(4)$ & $0,8302(6)$ \\
$r_{1}(6)$ & $0,8984(1)$ & $0,6158(3)$ & $0,8237(7)$ \\
$r_{1}(7)$ & - & - & $0,9563(8)$ \\
$r_{1}(8)$ & - & - & $0,7390(9)$ \\
$r_{1}(9)$ & - & - & 0,9151 \\
$Q_{1}$ & 0,9429 & 0,8111 & \\
\hline
\end{tabular}

Medidas de BOTAO, FRUIMA, NV BOTAO, FRUIMA, NV BOTAO, FRUIMA, NV Similaridade:

Agronômicos

\begin{tabular}{cccc}
\hline$r_{1}(1)$ & $0,9745(1)$ & $0,9745(1)$ & $0,9745(1)$ \\
$r_{1}(2)$ & $0,9924(2)$ & $0,9924(2)$ & $0,9924(2)$ \\
$r_{1}(3)$ & $0,9818(3)$ & $0,9818(3)$ & $0,9818(3)$ \\
$Q_{1}$ & 0,9811 & 0,9811 & 0,9811 \\
\hline
\end{tabular}




\subsubsection{Seleção conjunta de descritores de folha, flor, fruto e agronômicos}

Após a eliminação na primeira fase das variáveis redundantes dentro de cada grupo de descritores, foram selecionadas 29 variáveis, incluindo: folha: LLTOPO; CPF; EL; CA; LA; ANB; e DN; flor: CBE, TFL, CP, DP, CES, DO, NO, VGP, CLP, e CE; fruto: DL, PCA, ECA, DTS, SN, SC, AC, BRIX, e PH; agronômicos: BOTAO, FRUIMA e NV.

Na obtenção da lista mínima de descritores de cupuaçuzeiro, foi realizada uma análise de componentes principais com essas 29 variáveis em conjunto, seguindo o mesmo procedimento metodológico da etapa anterior. Nessa segunda etapa, foi possível descartar mais dez variáveis, que apresentavam redundância inter-grupo (Tabela 6). A taxa de descarte final foi, portanto, de $64 \%$ do total de descritores propostos inicialmente. Após os dois ciclos de seleção, a lista mínima ficou composta por 19 descritores, sendo quatro de folha (CPF, EL, LA, ANB); sete de flor (CBE, CP, DP, DO, NO, CLP, CE); cinco de fruto (DTS, SC, AC, BRIX, e PH); e três agronômicos (BOTAO, FRUIMA e NV). Os descritores de flor foram os que mais contribuíram para compor essa lista final, o que corrobora os resultados preliminares obtidos. O número de descritores agronômicos manteve-se inalterado da primeira para a segunda etapa, enquanto os grupos de descritores de fruto, folha e flor sofreram reduções de 44, $43 \mathrm{e}$ $30 \%$, respectivamente. A lista mínima de descritores aqui proposta deverá ser complementada, futuramente, com descritores qualitativos, especialmente os relacionados com flor e fruto.

Em capim-elefante, foram avaliados 15 descritores reprodutivos, 22 vegetativos e 21 agronômicos para descartar os descritores considerados redundantes ou não discriminantes (Strapasson, 1997), sendo possível, utilizando método semelhante, reduzir em 53\%, 68\% e $43 \%$, respectivamente, do conjunto original de descritores. Uma segunda análise foi realizada conjuntamente com os descritores selecionados, e verificou-se que oito descritores seriam os mais importantes na caracterização dos acessos. Em cacaueiro, Bekele et al. (1994), partindo de um conjunto de 68 variáveis quantitativas e qualitativas, através de análise de componentes principais, selecionaram um sub-conjunto preliminar de 34 variáveis, que após análises de correlações múltiplas, definiram uma lista mínima de 23 descritores para a caracterização de germoplasma de cacaueiro. 
Tabela 6. Descritores selecionados na primeira e segunda etapa de descarte, empregando os Métodos I, II e misto.

\begin{tabular}{|c|c|c|c|c|c|c|}
\hline \multirow[t]{2}{*}{ Descritores } & \multicolumn{3}{|c|}{ Pré-seleção ( $1^{\mathrm{a}}$ etapa) } & \multicolumn{3}{|c|}{ Seleção final ( ${ }^{\mathrm{a}}$ Etapa) } \\
\hline & Método I & Método II & Misto & Método I & Método II & Misto \\
\hline CF & DESC & DESC & $\begin{array}{l}\text { Folha } \\
D E S C\end{array}$ & 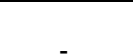 & - & \\
\hline LLBASE & DESC & DESC & DESC & - & - & - \\
\hline LLMEIO & DESC & DESC & DESC & 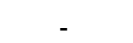 & 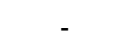 & \\
\hline LLTOPO & PSEL & DESC & PSEL & DESC & DESC & DESC \\
\hline CPF & DESC & PSEL & PSEL & PSEL & PSEL & SEL \\
\hline DPF & DESC & DESC & DESC & & & \\
\hline $\mathrm{EL}$ & PSEL & PSEL & PSEL & PSEL & DESC & SEL \\
\hline $\mathrm{CA}$ & PSEL & DESC & PSEL & DESC & DESC & DESC \\
\hline LA & DESC & PSEL & PSEL & PSEL & PSEL & SEL \\
\hline ANB & DESC & PSEL & PSEL & PSEL & PSEL & SEL \\
\hline ANM & DESC & DESC & DESC & & - & \\
\hline ANT & DESC & DESC & DESC & - & 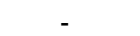 & \\
\hline DN & PSEL & DESC & PSEL & DESC & DESC & DESC \\
\hline NPN & DESC & DESC & $\begin{array}{l}\text { DESC } \\
\text { Flor }\end{array}$ & Sedo & - & 0 \\
\hline $\mathrm{CBE}$ & PSEL & PSEL & PSEL & DESC & PSEL & SEL \\
\hline DBE & DESC & DESC & DESC & & & \\
\hline TFL & DESC & PSEL & PSEL & DESC & DESC & DESC \\
\hline DEA & DESC & DESC & DESC & 年 & 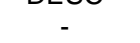 & \\
\hline $\mathrm{CP}$ & PSEL & DESC & PSEL & PSEL & DESC & SEL \\
\hline DP & PSEL & PSEL & PSEL & PSEL & DESC & SEL \\
\hline CES & DESC & PSEL & PSEL & DESC & DESC & DESC \\
\hline $\mathrm{CO}$ & DESC & DESC & DESC & & & \\
\hline DO & PSEL & PSEL & PSEL & PSEL & PSEL & SEL \\
\hline NO & PSEL & DESC & PSEL & PSEL & DESC & SEL \\
\hline VGP & DESC & PSEL & PSEL & DESC & DESC & DESC \\
\hline CLS & DESC & DESC & DESC & & 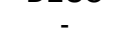 & \\
\hline LLS & DESC & DESC & DESC & & 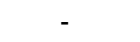 & \\
\hline CLP & PSEL & PSEL & PSEL & DESC & PSEL & SEL \\
\hline LLP & DESC & DESC & DESC & - & - & 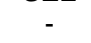 \\
\hline CC & DESC & DESC & DESC & - & - & - \\
\hline LC & DESC & DESC & DESC & - & - & 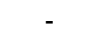 \\
\hline $\mathrm{CE}$ & PSEL & DESC & $\begin{array}{l}\text { PSEL } \\
\text { Fruto }\end{array}$ & PSEL & DESC & SEL \\
\hline DL & PSEL & DESC & PSEL & DESC & DESC & DESC \\
\hline DT & DESC & DESC & DESC & - & - & 0 \\
\hline PFR & DESC & DESC & DESC & - & - & \\
\hline PCA & PSEL & DESC & PSEL & DESC & DESC & DESC \\
\hline PPO & DESC & DESC & DESC & & & \\
\hline ECA & PSEL & PSEL & PSEL & DESC & DESC & DESC \\
\hline ES & DESC & DESC & DESC & - & - & - \\
\hline DLS & DESC & DESC & DESC & 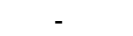 & - & \\
\hline DTS & PSEL & PSEL & PSEL & PSEL & PSEL & SEL \\
\hline SN & PSEL & PSEL & PSEL & DESC & DESC & DESC \\
\hline SC & DESC & PSEL & PSEL & PSEL & PSEL & SEL \\
\hline$A C$ & PSEL & DESC & PSEL & PSEL & PSEL & SEL \\
\hline BRIX & DESC & PSEL & PSEL & DESC & PSEL & SEL \\
\hline $\mathrm{PH}$ & DESC & PSEL & PSEL & PSEL & PSEL & SEL \\
\hline UM & DESC & DESC & DESC & & & \\
\hline & & & Agronômic & & & \\
\hline PROD & & & os & - & - & - \\
\hline RRTA & DESC & DESC & DESC & rän & DCFI & וזים \\
\hline $\begin{array}{l}\text { BOTAO } \\
\text { FIOB }\end{array}$ & $\begin{array}{l}\text { PSEL } \\
\text { DFSC }\end{array}$ & $\begin{array}{l}\text { PSEL } \\
\text { DESC }\end{array}$ & PSEL & DESC & PSEL & SEL \\
\hline FRUIMA & PSEL & PSEL & PSEL & PSEL & PSEL & SEL \\
\hline NV & PSEL & PSEL & PSEL & DESC & PSEL & SEL \\
\hline
\end{tabular}


Para comparar os resultados obtidos utilizando as duas etapas de seleção de variáveis com o processo mais rotineiramente empregado na literatura, que é a seleção em uma única etapa (direta), foi realizada uma nova análise de componentes principais envolvendo todas as 53 variáveis. Pelo método direto, foram selecionados 21 descritores (Tabela 7), com uma taxa de descarte de $60,4 \%$, sendo que dentro dos quatro conjuntos de variávies, a intensidade de descarte não foi uniforme, sendo eliminados $68,8 \%$ dos descritores de fruto, enquanto que apenas $40 \%$ dos agronômicos. A coincidência entre as listas de descritores pelos dois métodos não é completa, porém dos 19 descritores selecionados em duas etapas, 11 foram selecionados pelo método direto.

Tabela 7. Descritores selecionados pelo método direto, com base em todos os 53 descritores, e percentagem de descarte dentro de cada conjunto.

\begin{tabular}{llc}
\hline \multicolumn{1}{c}{ Conjunto } & \multicolumn{1}{c}{ Descritores } & \% Descarte \\
\hline Folha & CF, EL, LA, ANB, NPN & 64,3 \\
Flor & CBE, DEA, CP, CES, DO, NO, LLP, CC & 55,6 \\
Fruto & DL, DTS, SC, SN, UM & 68,8 \\
Agronômicos & FLOR, FRUIMA, NV & 40,0 \\
Geral & & 60,4 \\
\hline
\end{tabular}

\subsubsection{Avaliação da eficiência dos conjuntos selecionados}

Para comparar a eficiência dos conjuntos de descritores selecionados na $1^{\mathrm{a}}$ etapa (29 variáveis), $2^{a}$ etapa (19 variáveis) e seleção direta com todas as 53 variáveis (21 variáveis) foram efetuadas medidas de similaridade, $r_{1}$ e $Q_{1}$, entre os três conjuntos reduzidos e o original (Tabela 8 ).

O conjunto pré-selecionado na primeira etapa revelou uma perfeita ordenação entre os três primeiros componentes, que são os mais importantes por deterem a maior porção da variação total . O quarto é uma mescla do quarto e quinto componentes reduzidos, assim como o sexto é uma mescla do sexto e sétimo. A partir desse ponto ocorrem pequenas alterações na ordenação dos componentes, mas entre o $14^{\circ} \mathrm{e} 018^{\circ}$ componentes a ordenação foi perfeita. A magnitude dos coeficientes de correlação 
entre os componentes foi elevada, sendo que a correlação entre os dois conjuntos medidos pelo índice $Q_{1}$ foi o maior de todas as seleções realizadas.

Com o conjunto selecionado na segunda etapa (seleção final) a ordenação dos componentes sofreu pequenas alterações desde o primeiro componente. A magnitude das correlações, porém, foi relativamente elevada, semelhante ao observado na seleção efetuada na primeira fase, tanto entre os pares de componentes principais $\left(r_{1}\right)$, como entre os dois conjuntos $\left(Q_{1}\right)$. A seleção direta efetuada com base em todas variáveis conjuntamente, apesar de revelar boa ordenação até o quarto componente, apresentou, a partir daí alterações nessa ordenação. Em relação aos dois

conjuntos anteriores, notou-se uma diminuição da maioria dos valores de coeficientes de correlação $r_{1}$, assim como na medida de similaridade $Q_{1}$.

Esses resultados demonstraram que o conjunto de 29 variáveis, obtido na primeira etapa de seleção, poderia ser usado no estudo de divergência fenética do cupuaçuzeiro, pois a perda de informação decorrente da não utilização das outras 24 variáveis, seria mínima, e só contribuiriam para uma análise mais trabalhosa, e não necessariamente mais precisa. O segundo conjunto composto por 19 variáveis indicou também ser suficientemente informativo, sendo aqui proposto sua utilização como uma lista mínima de descritores a serem empregados na caracterização de coleções de cupuaçuzeiro. Esta lista deverá representar uma ferramenta importante na mensuração da variabilidade dentro das coleções, promovendo um conhecimento mais aprofundado das potencialidades das coleções de cupuaçuzeiro existentes na região Amazônica, com uso racionalizado da escassa mão de obra especializada existente, propiciando economia de tempo e recursos materiais, porém disponibilizando informações valiosas para a conservação e melhoramento genético da espécie.

\subsubsection{Divergência fenética por marcadores botânico-agronômicos}

Foi estimada a distância fenética entre cada par de acessos por meio da distância Eulideana média padronizada, envolvendo os 19 descritores selecionados (Anexo F). A distribuição das estimativas das distâncias entre todos os acessos da 
coleção, com média geral de 1,39 e amplitude de 0,73 (acessos 184 e 623) à 2,11 (acessos 151 e 185). As maiores distâncias foram observadas entre os acessos 151 e $185 ; 185$ e 554; 136 e 185; 136 e 248, com valores de 2,11, 2,11, 2,05 e 2,03, respectivamente. Os acessos 151 e 136 foram coletados em Tefé (AM), enquanto que 185 foi coletado em Codajás (AM). Em média os acessos 185, 554 e 151, foram os que apresentaram os maiores valores de divergência, informação que será útil para a escolha de genitores no programa de hibridação, visto que são acessos que possuem caracteres agronômicos interessantes para o melhoramento genético. Os acessos 185 e 151 produziram frutos com peso em torno de $1.700 \mathrm{~g}$, muito acima da média que foi de $1.266 \mathrm{~g}$, porém apresentaram susceptibilidade à vassoura-de-bruxa. Por outro lado, o acesso 554 ficou livre da doença durante os cinco anos do experimento, porém produziu frutos pequenos. $O$ fato dos acessos terem sido coletados vegetativamente resultou na fixação de todos os caracteres morfológicos das plantas coletadas nos locais de origem. Isto acentuou a divergência natural encontrada entre os acessos e demonstrou também que estas diferenças, fator da seleção por ocasião da coleta, têm forte componente genético. As menores distâncias foram registradas entre os acessos 184 e 623; 181 e 622; 184 e 623 com valores de 0,73, 0,74 e 0,74, respectivamente, apesar desses genótipos terem sido coletados em locais distinto. Como exemplo, os acessos 181 e 184 são procedentes do oeste do Amazonas, enquanto que os acessos 622 e 623 são oriundos do extremo norte do Amapá. Coincidentemente, foram esses acessos que apresentaram as menores divergências médias em relação aos demais materiais da coleção. No estádio atual do melhoramento do cupuaçuzeiro uma das metas é identificar genitores que produzam progênies com comportamento relativamente uniforme, resistentes à vassoura-de-bruxa e boa produção de frutos, isto é, superior a $30 \mathrm{~kg}$ de frutos/safra/ano. Avaliar a capacidade geral e específica dos acessos mais similares, e que reunam os caracteres agronômicos desejáveis, parece ser uma estratégia promissora. Portanto, o conhecimento das relações fenéticas entre os acessos permitirá restringir o número de genitores a serem escolhidos. Por ser uma planta de propagação vegetativa indivíduos excepcionais poderão ser clonados em qualquer etapa do processo e, poderão ser imediatamente recomendados aos produtores na forma de clones. Por outro lado, quando o interesse for amplificar a variabilidade, para selecionar e clonar os indivíduos transgressivos, a escolha deverá recair sobre os genótipos mais divergentes. 
Tabela 8. Estimativas de medidas de similaridade, $r_{1}(j)$ e $Q_{1}$, entre componentes principais para os conjuntos completo e selecionado dos 53 descritores, com seleção escalonada em duas etapas e seleção direta de todos os descritores de cupuaçuzeiro.

\begin{tabular}{|c|c|c|c|}
\hline \multirow{3}{*}{$\begin{array}{l}\text { Medida } \\
\text { de } \\
\text { Simila- } \\
\text { ridade }\end{array}$} & \multicolumn{3}{|c|}{ Método de descarte - Descritores selecionados } \\
\hline & Pré-seleção (1ª etapa) & Sel. final $\left(2^{\mathrm{a}}\right.$ etapa $)$ & Seleção direta \\
\hline & $\begin{array}{l}\text { CBE,TFL,CP,DP,CES,D } \\
\text { O,NO,VGP,CLP,CE,DL, } \\
\text { PCA,ECA,DTS,SN,SC,A } \\
\text { C,BRIX,PH,LLTOPO,CP } \\
\text { F,EL,CA,LA,ANB,DN,B } \\
\text { OTAO,FRUIMA,NVM }\end{array}$ & $\begin{array}{l}\text { CBE,CP,DP,DO,NO,C } \\
\text { LPCE,DTS,SC,AC,BRI } \\
\text { X,PH,CPF,EL,LA,ANB, } \\
\text { BOTAO,FRUIMA,NV; }\end{array}$ & $\begin{array}{l}\text { CBE,DEA,CP,CES, } \\
\text { DO,NO,LLP,CC,DL, } \\
\text { DTS,SC,SN,UM,CF } \\
\text { ' EL,LA,ANB,NPN, } \\
\text { FLOR,FRUIMA,NV; }\end{array}$ \\
\hline$r_{1}(1)$ & $0,9710(1)$ & $0,8824(2)$ & $0,7409(1)$ \\
\hline$r_{1}(2)$ & $0,8969(2)$ & $0,9041(1)$ & $0,7326(2)$ \\
\hline$r_{1}(3)$ & $0,7592(3)$ & $0,7786(3)$ & $0,9259(3)$ \\
\hline$r_{1}(4)$ & $0,6291(4)$ & $0,5505(6)$ & $0,7548(4)$ \\
\hline$r_{1}(5)$ & $0,7254(4)$ & $0,6105(4)$ & $0,5463(7)$ \\
\hline$r_{1}(6)$ & $0,5322(6)$ & $0,7838(5)$ & $0,5715(6)$ \\
\hline$r_{1}(7)$ & $0,5509(6)$ & $0,6393(8)$ & $0,6354(5)$ \\
\hline$r_{1}(8)$ & $0,6784(8)$ & $0,5991(9)$ & $0,5578(5)$ \\
\hline$r_{1}(9)$ & $0,6409(10)$ & $0,4325(12)$ & $0,5633(8)$ \\
\hline$r_{1}(10)$ & $0,5834(13)$ & $0,5641(6)$ & $0,5957(11)$ \\
\hline$r_{1}(11)$ & $0,6589(9)$ & $0,5679(6)$ & $0,4787(10)$ \\
\hline$r_{1}(12)$ & $0,7501(12)$ & $0,7768(11)$ & $0,5139(7)$ \\
\hline$r_{1}(13)$ & $0,8501(11)$ & $0,6941(10)$ & $0,7624(9)$ \\
\hline$r_{1}(14)$ & $0,7497(14)$ & $0,7018(14)$ & $0,6533(14)$ \\
\hline$r_{1}(15)$ & $0,6086(15)$ & $0,7317(8)$ & $0,6470(11)$ \\
\hline$r_{1}(16)$ & $0,6077(16)$ & $0,4959(14)$ & $0,5395(10)$ \\
\hline$r_{1}(17)$ & $0,5588(17)$ & $0,6411(13)$ & $0,4203(13)$ \\
\hline$r_{1}(18)$ & $0,5011(18)$ & $0,6092(16)$ & $0,4895(10)$ \\
\hline$r_{1}(19)$ & $0,5601(21)$ & $0,4905(17)$ & $0,5572(12)$ \\
\hline$r_{1}(20)$ & $0,5966(18)$ & - & $0,5865(17)$ \\
\hline$r_{1}(21)$ & $0,6617(19)$ & - & $0,5062(18)$ \\
\hline$r_{1}(22)$ & $0,7581(20)$ & - & - \\
\hline$r_{1}(23)$ & $0,5746(25)$ & - & - \\
\hline$r_{1}(24)$ & $0,6031(23)$ & . & - \\
\hline$r_{1}(25)$ & $0,5535(24)$ & - & - \\
\hline$r_{1}(26)$ & $0,4522(26)$ & - & - \\
\hline$r_{1}(27)$ & $0,4249(19)$ & - & - \\
\hline$r_{1}(28)$ & $0,7699(24)$ & - & - \\
\hline$r_{1}(29)$ & $0,4407(24)$ & - & - \\
\hline$Q_{1}$ & 0,7674 & 0,7446 & 0,6883 \\
\hline
\end{tabular}

Nota: entre parênteses encontra-se o número do componente do conjunto de dados selecionados mais altamente correlacionado com o j-ésimo componente do conjunto de dados completo. 
Pelo exposto, os quatro acessos que serão brevemente recomendados aos produtores, 174, 186, 215 e 286, por apresentarem parte das exigências aqui mencionadas quanto a resistência à vassoura-de-bruxa e produtividade, deverão fazer parte de um experimento em dialelo para definir os cruzamentos mais promissores.

Comparando a divergência entre os acessos coletados no mesmo local de coleta foi verificada uma tendência da maioria apresentar valores de divergência muito abaixo da média, demonstrando existir relacionamento genético entre eles. Possivelmente isto seja decorrente do fato dos acessos terem sido coletados em pomares caseiros e pequenos plantios, onde as mudas foram preparadas a partir de sementes oriundas de um ou poucos frutos, podendo haver casos de progênies de irmãos germanos ou meios irmãos. A divergência entre plantas dentro de cada local será, portanto, função do número e dos caracteres genéticos das matrizes fornecedoras das sementes. Por ocasião da coleta foi realizada a propagação vegetativa, com isso o genótipo de cada acesso foi fixado integralmente, consequentemente, as diferenças entre eles refletem integralmente as diferenças existentes entre as plantas coletadas.

Segundo Silva (1996) mecanismos de incompatibilidade dificultam que clones geneticamente próximos, efetuem trocas gênicas. Os resultados aqui obtidos de divergência fenotípicas, complementados com outras informações obtidas da compatibilidade entre os acessos do BAG (Alves et al., 1997a), permitem sugerir, que acessos fenotipicamente similares deverão ter mais dificuldade de trocar genes, visto que, em alguns casos, a compatibilidade entre acessos de um mesmo local de coleta tende a ser baixa. Entretando, em outras situações, ocorre o inverso, isto é, acessos de uma mesma região apresentam boa compatibilidade, que pode ser decorrente da origem diversa dos acessos dentro do referido local. Portanto, somente através de cruzamentos controlados, envolvendo materiais de origem genética conhecida, essa situação poderá ser esclarecida. Tal esclarecimento reveste-se de importância pois o melhoramento do cupuaçuzeiro tende à produzir sementes clonais (híbridos), envolvendo poucos clones elites. Portanto, haveria um estreito relacionamento genético entre as sementes produzidas. Caso haja 
decréscimo de compatibilidade entre os materiais aparentados, a produtividade será afetada. Assim, somente com a ampliação do leque de clones genitores o problema poderia ser contornado.

\subsubsection{Análise de Agrupamento}

A análise de agrupamento pela técnica de Tocher com base na matriz de dissimilaridade fundamentada na distância Euclideana média padronizada, revelou o aparecimento de seis grupos (Tabela 9). O primeiro grupo foi o mais numeroso com 20 acessos, com representantes das três procedências, Amazonas, Pará e Amapá. Nesse grupo encontram-se três dos quatro acessos, resistentes à vassoura-de-bruxa, 174, 186 e 215. Outro acesso bastante promissor encontrado nesse grupo foi o 1074, que apesar de ser susceptível à vassoura-de-bruxa, apresenta frutos grandes com peso médio superior a $2 \mathrm{~kg}$. O segundo grupo (II), formado por quatro materiais, foi totalmente constituído por acessos paraenses. $O$ destaque desse grupo foi o acesso 286 também resistente à vassoura-de-bruxa. Os acessos 434 e 435 oriundos da mesma localidade no Pará (Muaná), confirmam aqui sua proximidade genética. Silva (1996) já havia demonstrado que esses dois acessos possuíam uma ancestralidade recente, que possivelmente explicariam o baixo índice de compatibilidade entre eles observada. Os três acessos que constituem o grupo III são todos de procedência amazonense, sendo que os acessos 136 e 151 são oriundos da mesma localidade (Tefé/AM). O grupo IV foi formado por dois acessos e os grupos $\mathrm{V}$ e $\mathrm{VI}$ por um acesso cada.

Tabela 9. Grupos de dissimilaridade obtidos pelo método de Tocher, a partir das distâncias Euclideanas média padronizadas, estimadas em 31 acessos do BAG de cupuaçuzeiro, avaliados para 19 descritores selecionados.

\begin{tabular}{llll}
\hline Grupos & Acessos & & \\
\hline I & 184(AM), 623(PA), 622(PA), 181(AM), 183(AM), 1074(AM), 228(AM), \\
& 513(AP), 174(AM), 514(AP), 247(AM), 229(AM), 227(AM), 512(AP), \\
& 620(PA), 186(AM), 215(AM), 516(AP); 219(AM), 216(AM); \\
II & 286(PA), 434(PA), 618(PA), 435(PA); \\
III & $12($ AM $), 136($ AM); 151(AM); \\
IV & 185(AM), 624(PA); \\
V & 248(AM); \\
VI & 554(PA), \\
\hline
\end{tabular}


Foi realizada também a análise de agrupamento hierárquico aglomerativo pelo método UPGMA com base na matriz de distâncias Euclideana média padronizada (Figura 2). Para decidir o número de grupos formados no dendrograma, foi adotado como ponto de corte, o local de mais alta mudança de nível (Frieman \& Rubin, 1967). A análise de agrupamento realizada com os 19 descritores selecionados, apresentou agrupamentos muito similares aos obtidos pelo método de Tocher. Os acessos foram classificados em quatro grandes grupos, sendo que os acessos 554 (PA) e 185 (AM) não foram incluídos em nenhum grupo. Os acessos do estado do Amazonas constituíram os grupos I [12(AM), 136(AM), 151(AM)] e grupo II - [174(AM), 186(AM), 215(AM), 216(AM)]; além de comporem $50 \%$ dos acessos do grupo III [181(AM), 622(PA), 184(AM), 623(PA), 513(AP), 183(AM), 1074(AM), 228(AM), 247(AM), 219(AM), 512(AP), 620(PA), 227(AM), 229(AM), 248(AM), 514(AP), 516 (AP) e 624(PA)]. Foi observado que os acessos do Amazonas 174, 186, 215 e 216, que encontravam-se, pelo método de Tocher juntos no grupo maior (Grupo I) foram separados no método UPGMA.

Os acessos do Pará foram reunidos no grupo IV [286(PA), 434(PA), 618(PA), 435(PA)], com quatro acessos no grupo III, resultado similares aos obtidos pela metodologia anterior. Foi interessante observar que os acessos 286 e 554 procedentes do Pará, que apresentam como característica principal a resistência à vassoura-de-bruxa, ficaram muito distantes feneticamente dos clones resistentes do Amazonas. Esta grande diversidade permite levantar a hipótese de que a origem da fonte de resistência poderá ser divergente.

Os acessos do Amapá ficaram todos agrupados no grupo III, mostrando muita similaridade com acessos do Pará. A pouca variabilidade encontrada indica que a origem genética dos acessos é muito restrita, visto que o Amapá não é zona de ocorrência natural e, portanto, as sementes devem ter sido introduzidas de outras regiões, provavelmente, do Pará. 
Distância de Ligação
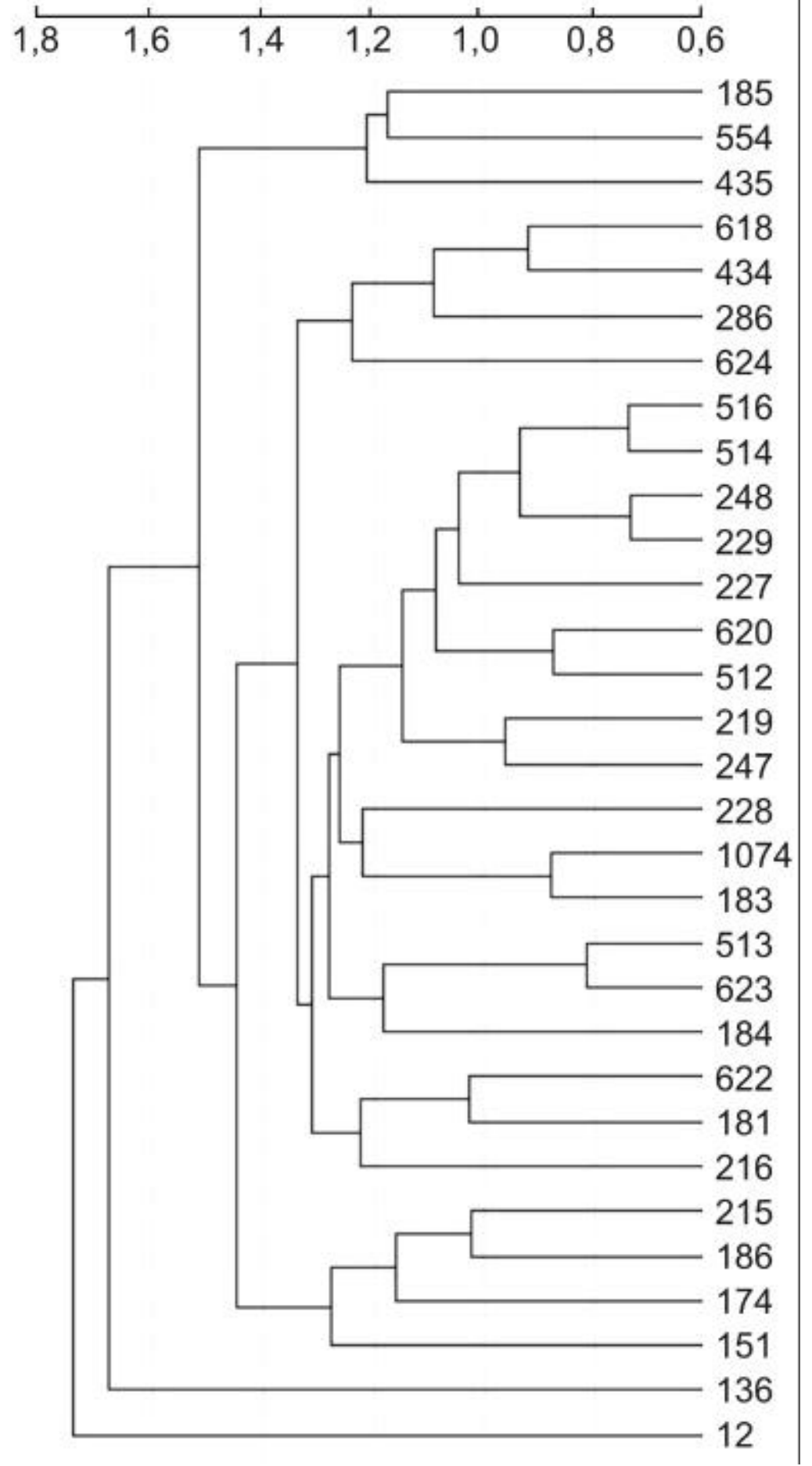

Figura 2 - Representação gráfica da análise de agrupamento, baseada nas distâncias Euclideanas médias de 31 acessos do BAG de $T$. grandiflorum, pelo método UPGMA, utilizando 19 descritores botânicoagronômicos. 
Assim como o Amapá, o estado do Amazonas também não é considerada zona de distribuição natural do cupuaçuzeiro. As sementes que originaram esses acessos, foram provavelmente introduzidas do Pará ou Maranhão pela movimentação das nações indígenas no interior da Amazônia, bem como, pelo intenso tráfego de passageiros ao longo da calha do rio Amazonas, que possibilitaram a dispersão do cupuaçuzeiro até o extremo oeste do estado. A coleta sendo realizada em diferentes pontos ao longo do rio Amazonas, foi responsável pela grande variabilidade observada entre os acessos.

\subsubsection{Concordância entre caracterização genética e fenotípica no estudo da diversidade genética}

O estudo comparativo entre os métodos de estimação das distâncias por marcadores microssatélites com base em 21 locos microssatélites e 19 descritores quantitativos botânico-agronômicos (Capítulo 5) de 31 acessos do Banco Ativo de Germoplasma de cupuaçuzeiro revelou, pelo teste de Mantel, forte e significativa associação (Figura 3 ) entre esse dois tipos de marcadores $(r=0,72)$. Com base nas distâncias genéticas e fenotípicas foram construídos dois dendrogramas (Figura 2 e 3), que permitiram discriminar as interrelações entre os 31 acessos do BAG. 


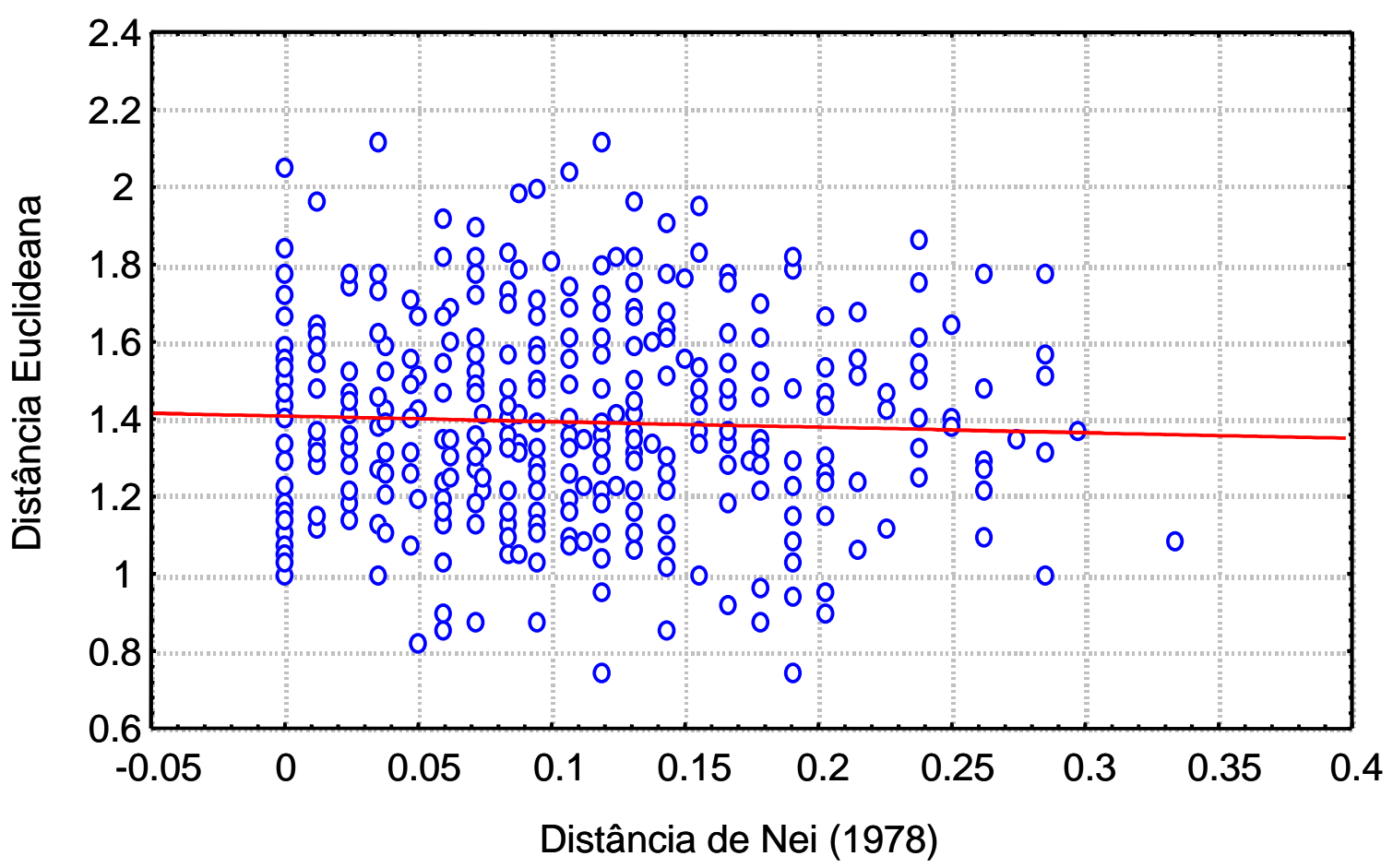

Figura 3 - Correlação entre distâncias genéticas (Nei, 1978) e distâncias fenotípicas (distâncias Euclideana média), entre 31 acessos de $T$. grandiflorum.

Como microssatélites são seqüências repetitivas de DNA sem função codante, este resultado sugere que possivelmente alguns locos microssatélites encontrem-se em desequilíbrio de ligação com seqüências responsáveis pelas 19 características fenotípicas avaliadas e, portanto, não segregam independentemente, daí os dois conjuntos de informações promoverem resultados concordantes. Esse resultado indica a possibilidade de identificar bandas microssatélites associadas a características quantitativas de interesse (QTLs) para o melhoramento do cupuaçuzeiro, especialmente produção de frutos e resistência a doença vassoura-de-bruxa, que vem tornando limitante o desenvolvimento do cultivo dessa espécie na região amazônica. 


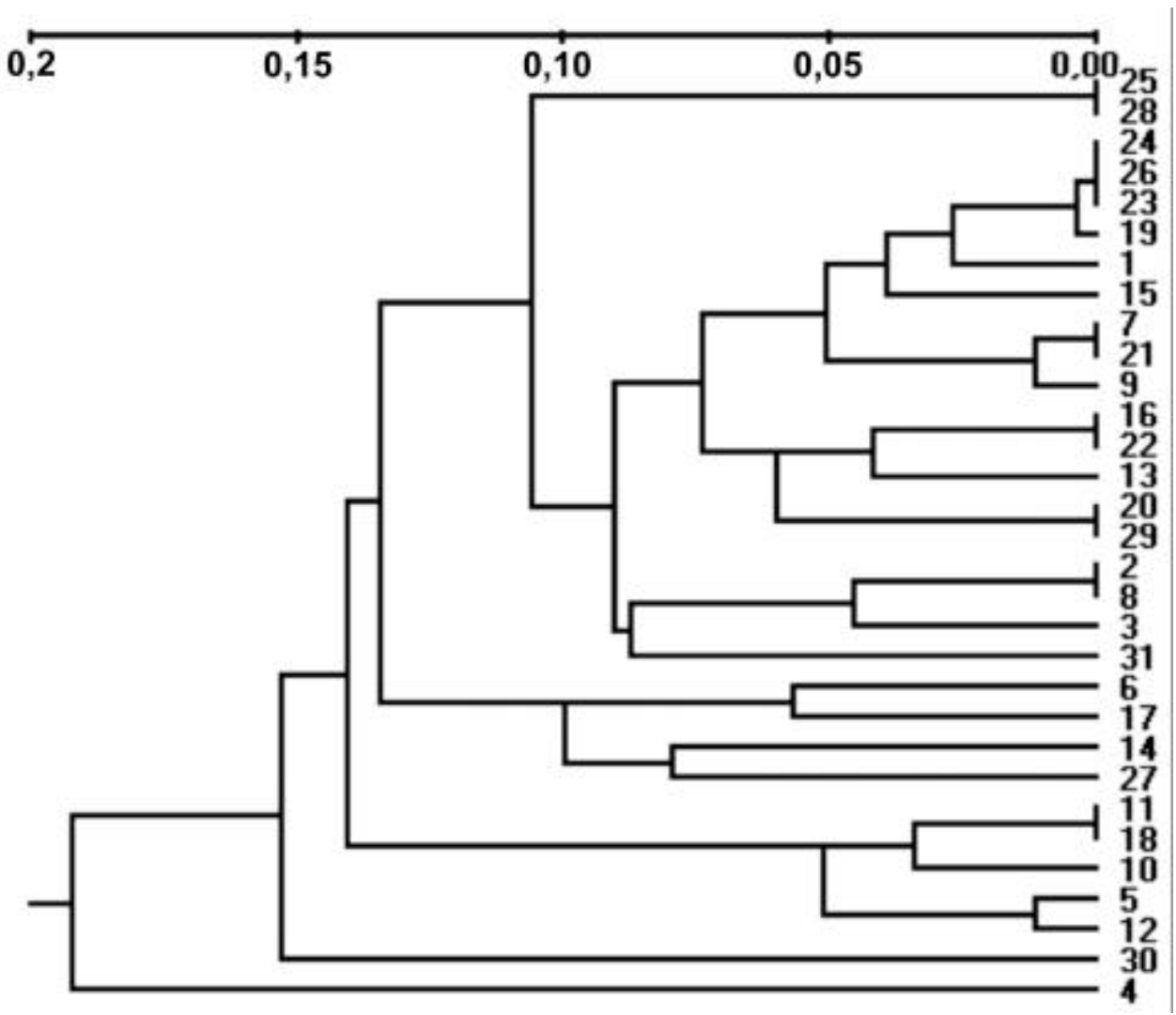

Figura 4 - Representação gráfica da análise de agrupamento, baseada nas distâncias genéticas não versadas de Nei (1978) de 31 acessos do BAG de T. grandiflorum, pelo método UPGMA, utilizando microssatélites.

\subsection{Conclusões}

A lista mínima de descritores para o cupuaçuzeiro é composta pelo comprimento do pecíolo foliar; espessura do limbo; largura do ácume; angulação das nervuras de base; comprimento do botão estriado; comprimento do pedúnculo floral; diâmetro do pedúnculo floral; diâmetro do ovário; número de óvulos; comprimento da lâmina da pétala; comprimento dos estaminóides; diâmetro transversal da semente; semente chocha; acidez; brix; $\mathrm{pH}$; número de botões caídos ao solo; número de frutos imaturos caídos precocemente e número de vassouras-de-bruxa produzidas. 
O método de descarte de variáveis, através de utilização da análise de Componentes Principais, em duas etapas de seleção, possibilita uma redução de $64 \%$ dos descritores inicialmente considerados.

Descritores agronômicos podem ser utilizados na caracterização de coleções, porém, devido serem altamente influenciados pelo ambiente, devem ser avaliados no tempo e, se possível, no espaço.

A redundância dos descritores descartados é confirmada pelo estudo de correlação entre o grupo descartado e o selecionado, indicando que os descritores descartados são plenamente dispensáveis, pois eles são responsáveis pelo mesmo tipo de informação já contida nos descritores selecionados.

Entre os descritores selecionados são poucas as combinações que apresentam correlação significativa, o que não ocorre entre os descritores descartados. Isto indica que, cada descritor selecionado é responsável por um tipo de informação biológica exclusiva e que a ação conjunta dos mesmos é complementar para a descrição geral dos acessos;

A partir dos 19 descritores selecionados é possível obter uma estimativa da variabilidade dos acessos do BAG de cupuaçuzeiro - Belém, através da análise de componentes principais, conjuntamente com o emprego da distância Euclideana média e agrupamento pelo método de Tocher e UPGMA;

A grande variabilidade observada para a maioria dos descritores empregados, é um indicativo de que a coleção é detentora de elevada diversidade fenotípica entre os acessos.

Correlação positiva e significativa entre distâncias genéticas e fenotípicas abre perspectivas de sucesso no mapeamento de QTLs para o melhoramento do T. grandiflorum, como as ligadas à produção de frutos e resistência à vassoura-debruxa. 


\section{SISTEMA DE REPRODUÇÃO EM POPULAÇÃO NATURAL DE CUPUAÇUZEIRO, Theobroma grandiflorum (Willd. ex Spreng.) Schum., COM BASE EM MARCADORES MICROSSATÉLITES}

\section{Resumo}

O objetivo deste trabalho foi estudar por marcadores microssatélites o sistema de reprodução de uma população natural de Theobroma grandiflorum, localizada em área de floresta densa de terra firme, no Município de Nova Ipixuna, Estado do Pará. Oito locos microssatélites polimórficos foram eficientemente transferidos do protocolo de Theobroma cacao para Theobroma grandiflorum. A amostragem incluiu oito progênies de polinização aberta, representadas cada uma por 10 plântulas com seis meses de idade. A estimativa da taxa de cruzamento multilocos $\left(\hat{t}_{m}=1,0\right)$ e individual por planta materna $(\hat{t}=1,0)$ revelou $T$. grandiflorum como uma espécie perfeitamente alógama. Da mesma forma, a estimativa da taxa de cruzamento unilocos $\left(\hat{t}_{s}\right)$ foi alta, 0,946, mas inferior a taxa $\hat{t}_{m}$, confirmando a alogamia na espécie e sugerindo a presença de $5,4 \%$ de cruzamentos entre parentes $\left(\hat{t}_{m}-\hat{t}_{s}\right)$. Contudo, a estimativa da divergência genética $\left(\hat{F}_{S T}\right)$ entre as freqüências alélicas dos óvulos e do pólen revelaram desvios de cruzamentos aleatórios em $75 \%$ dos locos avaliados. Em concordância, a estimativa da correlação de paternidade $\left(\hat{r}_{p}=0,930\right)$ e o coeficiente de coancestralidade médio dentro de progênies $\left(\hat{\theta}_{x y}=0,501\right)$ indicaram que os cruzamentos foram predominantemente biparentais e que as progênies eram aparentadas no grau de irmãos completos. Estes resultados sugerem que para esta população específica de $T$. grandiflorum, as estratégias de amostragem, para a conservação e melhoramento genético, devem adotar modelos específicos para progênies de cruzamentos biparentais (irmãos completos) e não os rotineiramente utilizados em programas de melhoramento de espécies alógamas (meios irmãos). 


\section{Summary}

The objective of this work was to study using microsatellite markers the mating system of a natural population of Theobroma grandiflorum, located in a dense forest in Nova Ipixuna, Pará state. Eight microsatellite polymorphic loci were analysed in eight families from open-pollinated, represented each one by 10 six-month old seedlings. The estimate for multilocus outcrossing rate $\left(\hat{t}_{m}=1.0\right)$ and individual outcrossing rate $(\hat{t}=1.0)$ indicated $T$. grandiflorum as a perfect allogamous species. Likewise, the estimate for single locus outcrossing rate $\left(\hat{t}_{s}\right)$ was high 0.946 , but lower than $\hat{t}_{m}$, confirming the allogamy of the species and suggesting the occurrence of $5.4 \%$ crosses

among relatives $\left(\hat{t}_{m}-\hat{t}_{s}\right)$. However, the estimation of genetic divergence $\left(\hat{F}_{S T}\right)$ among allele frequencies in ovules and pollen revealed a bias in random mating in $75 \%$ of loci evaluated. In agreement, the correlation of paternity estimate $\left(\hat{r}_{p}=0,930\right)$ and the mean coefficient of co-ancestrality within families $\left(\hat{\theta}_{x y}=0,501\right)$ indicated that the outcrossing were predominantly correlated and the offspring were related as full-sib. These results suggest that for this particular population of $T$. grandiflorum, the sampling strategy for genetic conservation and breeding should adopt specific models for families derived from correlated outcrossing (full - sib) and not the ones usually adopted in classic outcrossing species breeding programs (half - sibs).

\subsection{Introdução}

O sistema de reprodução de uma espécie determina como as informações genéticas serão transferidas de uma geração para outra (Wright, 1921), tendo, portanto, importância fundamental em programas de melhoramento e conservação genética. O conhecimento da forma como os genes serão combinados para gerar a próxima geração, permite delinear estratégias para a seleção de genótipos superiores e a retenção de parte da variabilidade genética para utilização futura.

O acúmulo de conhecimento sobre as espécies dos ecossistemas tropicais, tem permitido elucidar conceitos equivocados. Em trabalhos preliminares, Baker (1959) e Fedorov (1966) inferiram que a autogamia seria o sistema de reprodução 
predominante, tendo por base a assincronia na abertura das flores e dificuldade de mobilização dos polinizadores dentro da estrutura complexa da floresta. Foram somente com os trabalhos iniciados por Jansen (1971), sobre fluxo de pólen a longas distâncias, e levantamentos realizados por Bawa (1974), é que ficou constatado que as espécies arbóreas tropicais apresentavam diferentes estratégias para evitar autofecundação e privilegiar cruzamentos. Regra geral, as espécies enquadravam-se como de reprodução mista, predominantemente alógamas (Murawski \& Hamrick, 1992). Segundo Silva (1996) o hermafroditismo é o sistema sexual predominante nas espécies tropicais, porém quanto ao sistema de reprodução, em especial das espécies amazônicas, há necessidade de estudos mais abrangentes.

Estudos sobre o sistema de reprodução ganharam grande impulso, a partir da década de 70, com o advento das técnicas de biologia molecular, especialmente marcadores isoenzimáticos. Porém, foi com o desenvolvimento de metodologias de marcadores moleculares baseados em polimorfismo ao nível de seqüência de DNA, que esses estudos ganharam uma poderosa ferramenta. Marcadores microssatélites pertencem a essa categoria e, assim como marcadores isoenzimáticos, apresentam vantagens em estudos de sistemas de reprodução dada a expressão codominante e multialélica, e por serem robustos, confiáveis, e com boa praticidade operacional (Ferreira \& Grattapaglia, 1996). As frequencias alélicas podem ser calculadas diretamente, sem a necessidade de cruzamentos genéticos (Hamrick et al., 1979).

O T. grandiflorum é uma espécie frutífera arbórea tropical de origem amazônica. Mesmo nas áreas de maior concentração das populações nativas de $T$. grandiflorum, a densidade de plantas é relativamente baixa, com cerca de duas plantas por hectare (Homma et al., 2001). As plantas florescem no período de julho a dezembro, período mais seco do ano, e frutificam de agosto a abril (Prance \& Silva, 1975), sendo que o pico de frutificação acontece no primeiro trimestre do ano, o período das chuvas. A flor de T. grandiflorum, apesar de hermafrodita, apresenta barreiras anatômicas extremamente eficientes em dificultar o acesso direto dos grãos de pólen das anteras para o estigma. Silva (1996) observou que 100\% de autopolinização espontânea foi impedida simplesmente pelo fenômeno da hercogamia. Em $T$. cacao a presença de barreiras físicas na flor, favorece a alogamia, mesmo em indivíduos autocompatíveis (Souza \& Dias, 2001). 
Silva (1996) verificou também que $T$. grandiflorum não apresentava agamospermia, havendo, portanto, necessidade de polinização para que ocorresse formação de frutos. Em trabalhos realizados por Silva (1996) e Alves et al. (1997b), foi verificado que todas as tentativas de autofecundação forçada do cupuaçuzeiro não tiveram sucesso. Todos estes resultados indicaram que T. grandiflorum apresentaria mecanismo de auto-incompatibilidade, e forte tendência à alogamia como forma predominante de reprodução (Venturieri, 1993; Venturieri \& Ribeiro Filho, 1995; Silva, 1996; Alves et al., 1997b). Entretanto, Addison e Tavares (1951) encontraram uma matriz de cupuaçuzeiro que era tanto auto como alo-compatível. Verificaram que coincidentemente essa matriz era que mais facilmente se hibridizava com plantas das outras espécies do gênero, sugerindo que a base bioquímica do processo de inativação da incompatibilidade era a mesma, tanto intra específica quanto interespecífica.

A presença de auto-incompatibilidade parece ser comum em muitas espécies tropicais (Bullock, 1985) sendo uma forma eficiente para evitar endogamia. No gênero Theobroma sistemas de auto-incompatibilidade também parecem ser comuns, e foram bastante estudados em T. cacao (Cope, 1962; Knight \& Rogers, 1955). Aneja et al. (1994) trabalhando com o clone de T. cacao, auto-incompativel, IMC 30, verificou que o mecanismo de auto-incompatibilidade atuava em dois estagios, prevenindo inicialmente a germinação do pólen e, depois a fusão gamética. À semelhança de $T$. cacao, o T. grandiflorum apresenta auto-incompatibilidade com reação no ovário, prézigótica, ocorrendo abscisão da flor antes da formação do embrião.

Este trabalho teve por objetivo definir o sistema de reprodução de $\mathrm{T}$. grandiflorum estudando, com marcadores microssatélites, progênies de polinização aberta de uma população natural para respaldar o programa de melhoramento e conservação de recursos genético da espécie.Um nsferência de genes pela engenharia genética. 


\subsection{Material e métodos}

\subsubsection{Amostragem}

O estudo foi realizado em uma população natural de T. grandiflorum, localizada em área de floresta densa de terra firme, no Município de Nova Ipixuna, Estado do Pará (4 53’S; 4922’W). Foram coletadas borbullhas e folhas de 40 matrizes na população, em dezembro de 2001. Destas foi retirada uma sub-amostra, aleatória, de oito matrizes que possuiam frutos, e de cada matriz foram genotipadas 10 plântulas com seis meses de idade. A genotipagem foi realizada com marcadores microssatélites no Laboratório de Melhoramento de Plantas do CENA-USP, em Piracicaba, SP. Para a extração de DNA foi utilizado o protocolo de Doyle \& Doyle (1990), modificado por Figueira et al. (1997) para espécies de Theobroma. As reações de amplificação foram realizadas com 10 pares de primers desenvolvidos por Lanaud et al. (1999) para cacaueiro, porém que tinham demonstrado eficiência com outras espécies do gênero Theobroma, inclusive o T. grandiflorum. Os produtos de reação foram separados em gel de $6 \%$ poliacrilamida desnaturante com $7 \mathrm{M}$ de uréia, corrido eletroforeticamente em cuba vertical da Amersham Biosciences, modelo Hoefer SQ3 sequencer, e colorido com nitrato de prata (Creste et al., 2001).

\subsubsection{Análise Estatística}

O sistema de reprodução da população de $T$. grandiflorum foi analisado com base nos modelos de cruzamentos mistos de Ritland \& Jain (1981) e cruzamentos correlacionados (Ritland, 1989), com o auxílio do programa "Multilocos MLTR" (Ritland 1997). Os parâmetros estimados foram: a) a taxa de cruzamento multilocos $\left(\hat{t}_{m}\right)$, pelo método de máxima verossimilhança (Expectation-Maximization - EM); b) a taxa de cruzamento unilocos $\left.\left(\hat{t}_{s}\right) ; \mathrm{c}\right)$ a taxa de cruzamento entre aparentados $\left.\left(\hat{t}_{m}-\hat{t}_{s}\right) ; \mathrm{d}\right)$ a taxa de cruzamento multilocos individual $(\hat{t})$; e) as freqüências alélicas dos óvulos e pólen; f) o índice de fixação nas árvores maternas $\left.\left(\hat{F}_{m}\right) ; g\right)$ a correlação de paternidade $\left(\hat{r}_{p}\right)$ e h) o número provável de indivíduos polinizadores $\left(1 / \hat{r}_{p}\right)$. As pressuposições do modelo misto foram relatados por Ritland \& Jain (1981). O erro padrão das estimativas dos parâmetros foram obtido por 1.000 reamostragens bootstraps. O teste de cruzamentos 
aleatórios inicialmente foi abordado pelo teste de homogeneidade das freqüências alélicas dos óvulos e pólen, pela estimativa $\hat{F}_{S T}$ (Wright, 1965), utilizando-a apenas como uma medida de divergência genética entre freqüências alélicas de grupos distintos. Para testar a significância para cada loco, aplicou-se o teste de qui-quadrado $\left[\chi^{2}=2 n \hat{F}_{S T}(k-1) ; G L=(k-1)(s-1)\right]$, proposto por Workman \& Niswander (1970), em que: $n$ = número de gametas nos dois grupos (pólen e óvulos), $k=$ número de alelos e $s=$ número de grupos (no caso dois - pólen e óvulo). O índice de fixação nas progênies $\left(\hat{F}_{p}\right)$ e o coeficiente médio de coancestralidade entre plantas dentro de progênies $\left(\hat{\theta}_{x y}\right)$ foram obtidos pela análise da variância das freqüências gênicas e, seus respectivos intervalos de confiança, por 10.000 reamostragens bootstrap, estimativas obtidas a partir dofoi programa GDA (Lewis \& Zaykin, 1999).

\subsection{Resultados}

Dentre os 10 locos avaliados, dois foram monomórficos (CIR18 e CIR58) e oito polimórficos. Os locos polimórficos segregaram de dois a cinco alelos, totalizando 25 alelos na população (Tabela 1). Não foram detectados alelos exclusivos entre 0 pólen dos cruzamentos e os óvulos. Contudo, a estimação da divergência entre as freqüências alélicas dos óvulos e do pólen não foram homogêneas em $75 \%$ dos locos, revelando desvios de cruzamentos aleatórios (Tabela 1). As estimativas das taxas de cruzamentos individuais não variaram entre as árvores, sendo todos valores iguais a unidade (Tabela 2). A estimativa da taxa de cruzamento multilocos populacional $\left(\hat{t}_{m}\right)$ foi igual a 1,0, revelando que $T$. grandifloram é uma espécie perfeitamente alógama. Igualmente a estimativa da taxa de cruzamento unilocos $\left(\hat{t}_{s}\right)$ foi alta, 0,946 e significativamente diferente da unidade, a julgar pelo erro padrão da média $(0,029)$, mas inferior à estimativa da taxa de cruzamento multilocos, sugerindo a possibilidade de ter ocorrido cruzamentos entre indivíduos aparentados na população. A taxa de cruzamento estimada entre aparentados $\left(\hat{t}_{m}-\hat{t}_{s}\right)$ foi baixa $(5,4 \%)$, mas significativamente diferente de zero, considerando o erro padrão da média (Tabela 2). 
Tabela 1. Estimativa das freqüências alélicas no conjunto de pólen e óvulos, divergência genética $\left(\hat{F}_{S T}\right)$ entre freqüências alélicas do pólen vs. óvulos, valores de qui-quadrado $\left(\chi^{2}\right)$, graus de liberdade $(G L)$, número total de alelos $\left(n_{a}\right)$ e tamanho amostral $(n)$ em progênies de $T$. grandiflorum.

\begin{tabular}{|c|c|c|c|c|c|c|}
\hline Loco & Alelo & Pólen & Óvulos & $\hat{F}_{S T}$ & $\chi^{2}$ & $\mathrm{GL}$ \\
\hline \multirow[t]{3}{*}{ CIR17 } & 1 & 0,204 & 0,313 & & & \\
\hline & 2 & 0,718 & 0,563 & & & \\
\hline & 3 & 0,078 & 0,124 & 0,047 & $7,11^{*}$ & 2 \\
\hline \multirow[t]{2}{*}{ CIR31 } & 1 & 0,582 & 0,625 & & & \\
\hline & 2 & 0,418 & 0,375 & 0,004 & 0,56 & 1 \\
\hline \multirow[t]{3}{*}{ CIR33 } & 1 & 0,156 & 0,063 & & & \\
\hline & 2 & 0,342 & 0,250 & & & \\
\hline & 3 & 0,502 & 0,687 & 0,068 & $10,17^{* *}$ & 2 \\
\hline \multirow{3}{*}{ CIR19 } & 1 & 0,397 & 0,250 & & & \\
\hline & 2 & 0,119 & 0,688 & & & \\
\hline & 3 & 0,484 & 0,062 & 0,585 & $87,79^{* *}$ & 2 \\
\hline \multirow[t]{3}{*}{ CIR22 } & 1 & 0,316 & 0,250 & & & \\
\hline & 2 & 0,394 & 0,625 & & & \\
\hline & 3 & 0,290 & 0,125 & 0,100 & $15,02^{* *}$ & 2 \\
\hline \multirow[t]{3}{*}{ CIR43 } & 1 & 0,316 & 0,250 & & & \\
\hline & 2 & 0,394 & 0,625 & & & \\
\hline & 3 & 0,290 & 0,125 & 0,355 & 53,28 ** & 2 \\
\hline \multirow[t]{3}{*}{ CIR06 } & 1 & 0,310 & 0,250 & & & \\
\hline & 2 & 0,438 & 0,375 & & & \\
\hline & 3 & 0,252 & 0,375 & 0,026 & 3,87 & 2 \\
\hline \multirow[t]{5}{*}{ CIR61 } & 1 & 0,040 & 0,059 & & & \\
\hline & 2 & 0,179 & 0,176 & & & \\
\hline & 3 & 0,405 & 0,471 & & & \\
\hline & 4 & 0,363 & 0,235 & & & \\
\hline & 5 & 0,013 & 0,059 & 0,041 & $12,18^{*}$ & 4 \\
\hline$n_{a}$ & & 25 & 25 & & & \\
\hline$N$ & & 75 & 75 & & & \\
\hline
\end{tabular}


Tabela 2. Estimativa da taxa de cruzamento multilocos individual por planta materna $(\hat{t})$ e parâmetros do sistema de reprodução em uma população de $T$. grandiflorum.

\begin{tabular}{|c|c|c|}
\hline Progênie & $n$ & $\hat{t}$ \\
\hline 1 & 10 & $1,0(0,00)$ \\
\hline 2 & 10 & $1,0(0,00)$ \\
\hline 3 & 10 & $1,0(0,00)$ \\
\hline 4 & 5 & $1,0(0,00)$ \\
\hline 5 & 10 & $1,0(0,00)$ \\
\hline 6 & 10 & $1,0(0,00)$ \\
\hline 7 & 10 & $1,0(0,00)$ \\
\hline 8 & 10 & $1,0(0,00)$ \\
\hline Índice de fixação nas árvores maternas $\left(\hat{F}_{m}\right)$ & & $0,008(0,001)$ \\
\hline Índice de fixação nas progênies $\left(\hat{F}_{p}\right)$ & & $\begin{array}{c}-0,096(-0,377 \mathrm{a} \\
0,167)^{\mathrm{a}}\end{array}$ \\
\hline $\begin{array}{l}\text { Coeficiente de coancestralidade dentro de progênies } \\
\left(\hat{\theta}_{F}\right)\end{array}$ & & $\begin{array}{c}0,251(0,139 a \\
0,344)^{a}\end{array}$ \\
\hline Taxa de cruzamento unilocos $\left(\hat{t}_{s}\right)$ & & $0,946(0,029)$ \\
\hline Taxa de cruzamento multilocos $\left(\hat{t}_{m}\right)$ & & $1,000(0,000)$ \\
\hline Taxa de cruzamento entre aparentados $\left(\hat{t}_{m}-\hat{t}_{s}\right)$ & & $0,054(0,029)$ \\
\hline Correlação de paternidade $\left(\hat{r}_{P}\right)$ & & $0,930(0,135)$ \\
\hline Número provável de polinizadores $\left(1 / \hat{r}_{P}\right)$ & & 1,07 \\
\hline
\end{tabular}

a: Intervalo de confiança a $99 \%$ de probabilidade, estimado para 10.000 reamostragens bootstraps.

( ) Erro padrão da média, obtido por 1.000 reamostragens bootstrap. 
O índice de fixação estimado nas árvores maternas $\left(\hat{F}_{m}=0,008\right)$ e nas progênies $\left(\hat{F}_{p}=-0,096\right)$ foi baixo e não significativo, indicando ausência de endogamia (Tabela 2). A estimação do coeficiente de coancestralidade médio dentro de progênies assumiu valores próximos ao esperado em progênies de irmãos completos $\left(\hat{\theta}_{x y}=\right.$ 0,251 ) e foi estatisticamente diferente de zero, a julgar pelo erro padrão. Este resultado corrobora com a hipótese de desvios de cruzamentos aleatórios. Em concordância, a estimativa da correlação de paternidade $\left(\hat{r}_{p}\right)$ foi alta e estatisticamente diferente de zero $(0,930)$, evidenciando que grande parte das progênies foram produzidas por cruzamentos biparentais, ou seja, foram geradas pelo mesmo parental materno e paterno. A estimativa do número provável de árvores polinizadoras $\left(1 / \hat{r}_{p}=1,07\right)$, visto que foi ligeiramente superior a unidade, indica que em média dois polinizadores contribuíram para os cruzamentos.

\subsection{Discussão}

A estimação da taxa de cruzamento multilocos mostrou que T. grandiflorum é uma espécie perfeitamente alógama $(1,0)$. Igualmente, a estimação da taxa de cruzamento individual foi 1,0 para todas as árvores matrizes. A taxa de cruzamento em espécies hermafroditas depende de fatores tais como: presença e intensidade de mecanismos de auto-incompatibilidade; grau de protogenia e protandria; comportamento forrageiro dos polinizadores entre e dentro de árvores, o qual é influenciado pela densidade de florescimento das árvores na população e, aborto seletivo de frutos e sementes de autofecundação (Murawski \& Hamrick, 1991). Estudos prévios desenvolvidos por Venturieri (1994), Alves et al. (1997a) e Silva (1996), indicaram a alogamia como o provável sistema de reprodução do $T$. grandiflorum. A própria estrutura anatômica da flor de $T$. grandiflorum apresenta barreiras físicas para isolar o estigma das anteras, além de um complexo sistema de auto-incompatibilidade, que poderia tornar a espécie obrigatoriamente alógama (Venturieri, 1993; Venturieri \& Ribeiro, 1995). Sistemas de auto-incompatibilidade parecem ser comuns dentro do gênero Theobroma, e foram bastante estudados em T. cacao (Pound, 1932; Marshall, 1933; Cope, 1938 e 1962; Knight \& Rogers, 1955; Yamada et al, 1982). À semelhança 
do T. cacao, o T. grandiflorum apresenta auto-incompatibilidade com reação no ovário, pré-zigótica , ocorrendo abscisão da flor antes da formação do embrião. Sistemas de auto-incompatibilidade em árvores da floresta tropical, decorrem de mecanismos que visam manter a variabilidade genética dentro das populações. A ausência de autofecundação em T. grandiflorum, foi observada por vários autores, tanto pelo isolamento de botões florais (autopolinização espontânea), como também, autopolinização induzida, polinização feita com pólen da mesma planta (gueitonogamia) (Falcão \& Lleras, 1983; Machado \& Retto Júnior, 1991; Alves et al., 1996; Silva, 1996). Esses indícios, juntamente com os resultados aqui observados levam a crer que a espécie é realmente auto-incompatível. A identificação de como se processa esse controle genético da auto-incompatibilidade, requer futuros estudos específicos.

A alta taxa de cruzamento multilocos estimada em $T$. grandiflorum $(1,0)$ é comparável a encontrada em outras três espécies arbóreas tropicais. Em Quararibea asterolepis Pitt. a taxa de cruzamento multilocos foi igual à unidade $(1,008)$ (Murawski et al., 1990). Em Ceiba pentandra (L.) Gaertn. a taxa variou de 0,898 a 0,924, sugerindo reprodução por sistema misto, com predomínio de alogamia (Murawski \& Hamrick, 1992). Igualmente em Cariniana legalis Mart. O. Ktze. foram detectadas taxa de cruzamento multilocos variando de 0,901 a 0,990 (Sebbenn et al., 2000). Em Esenbeckia leiocarpa Engl., uma outra espécie arbórea tropical com indícios de autoincompatibilidade (Crestana et al., 1982), Seoane et al. (2001) detectaram altas taxas de cruzamentos multilocos (variação de 0,917 a 0,997). Segundo Seoane et al. (2001), uma das explicações para presença de autogamia em espécies predominantemente alógamas, decorreria do mecanismo de auto-incompatibilidade poder atuar de forma irregular ao longo do período de florescimento, podendo haver períodos mais favoráveis à autofecundação. No caso de T. grandiflorum, Silva (1996) não observou variação desse mecanismo, ao longo da floração. De modo geral, as espécies arbóreas tropicais mostram-se como de sistema misto com predominância de alogamia e a taxa de cruzamento estimada tem sido superior a $85 \%$. Plantas com longo ciclo de vida, como espécies arbóreas, tendem a acumular alta carga genética a partir de mutações somáticas. Tendo em vista que altas taxas de autofecundação em espécies com elevada carga genética, poderiam levar a extinção das populações Lande \& 
Schemske (1985) hipotetizaram que a seleção teria dirigido estas espécies para altas taxas de cruzamento. O grande número de flores produzidas por árvore também aumenta a probabilidade de autopolinização por cleistogamia e conseqüentemente a evolução de mecanismos que previnem tais eventos (Barrett et al., 1996). A reprodução por cruzamento seria um mecanismo para evitar a expressão de genes letais e semi letais em estado homozigoto, ou em outros termos, evitar a depressão por endogamia.

A estimação da divergência genética $\left(\hat{F}_{S T}\right)$ entre as freqüências alélicas do pólen vs óvulos, evidenciou desvios de cruzamentos aleatórios, para a grande maioria dos locos (75\%). Diferenças nas freqüências alélicas do pólen vs óvulo têm sido observadas em inúmeros estudos do sistema de reprodução em espécies arbóreas (Murawski et al., 1990; Khasa et al., 1993; Lee et al., 2000; Sebbenn et al., 2000; Rocha \& Aguilar, 2001). Estes desvios em espécies perfeitamente alógamas $(t=1)$, como T. grandiflorum tem implicações importantes nas estratégias de melhoramento e conservação genética. Os desvios aumentam o parentesco intraprogênies, acima do esperado para cruzamentos aleatórios, inflando as estimativas de parâmetros genéticos, como coeficientes de herdabilidade e ganhos na seleção (Squillace, 1974). Em programas de conservação, os desvios implicam que o tamanho amostral deve ser maior do que seria retido, caso os cruzamentos fossem aleatórios, devido ao fato de que o aumento de parentesco intra-progênies, reduz o tamanho efetivo amostrado.

A estimativa da correlação de paternidade foi alta $\left(\hat{r}_{p}=0,930\right)$, e indicou que grande parte das progênies são aparentadas no grau de irmãos completos. O número estimado de polinizadores efetivos, não excedeu a dois $\left(1 / r_{p}\right)$. A alta correlação de paternidade $\left(r_{p}\right)$ reforça a hipótese de desvios de cruzamentos aleatório. Poucos trabalhos realizados com espécies arbóreas tropicais reportam estimativas da correlação $r_{p}$. Em Esenbeckia leiocarpa Engl. (Seoane et al., 2001) as estimativas das correlações de paternidade variaram entre populações de 0,749 a 0,986, umas das mais altas detectadas em espécies arbóreas tropicais. Em Cariniana legalis Mart. O. Ktze. (Sebbenn et al., 2000) as correlações de paternidade variaram entre populações de 0,212 a 0,324. Em Tabebuia cassinoides (Lam.) A.P. de Candolle (Sebbenn et al., 
2001) a correlação de paternidade variou de 0,295 a 0,547. A causa dos cruzamentos biparentais pode ser atribuída ao comportamento dos polinizadores visitando de forma sistemática árvores próximas, poliandria ou depósito de múltiplos grãos de pólen de um simples polinizador e pequeno número de vizinhos próximos (Sun \& Ritland 1998) ou assincronismo no florescimento das árvores (Murawski, 1995). Possivelmente, vários destes fatores tenham contribuído para a alta taxa de cruzamento biparental observadas em T. grandiflorum. Tendo em vista que a viabilidade de pólen e estigma é praticamente simultânea em $T$. grandiflorum (Silva, 1996), a baixa densidade populacional, aliado com o assincronismo no florescimento, podem ser as causas prováveis dos cruzamentos biparentais observados. Alves et al. (1997c) estudando uma coleção ex situ de $T$. grandiflorum, verificaram diferenças estatística significantes entre a produção de flores dos acessos, bem como, o período de pico de floração. Murawski \& Hamrick (1991) observaram que, em populações de espécies arbóreas de baixa densidade, o pólen dos cruzamentos era menos diversificado do que em espécies de alta densidade. Outra causa pode ser o comportamento e/ou a densidade de polinizadores. Variações ambientais podem afetar o comportamento e/ou a densidade das populações de polinizadores, levando a alterações na taxa de cruzamento das espécies em diferentes populações (Murawski, 1995).

Uma alta taxa de correlação de paternidade $\left(r_{p}\right)$ implica que grande parte das progênies são aparentadas no grau de irmãos completos. A taxa de cruzamento multilocos $(1,0)$ estimada, combinada com a correlação de paternidade $\left(r_{p}\right)$, permite afirmar que aproximadamente $93 \%$ das progênies foram originadas por cruzamentos biparentais, sendo aparentadas no grau de irmãos completos, e somente $7 \%\left(1-r_{p}\right)$ por cruzamentos aleatórios, sendo aparentadas no grau de meios irmãos, portanto as progênies de T. grandiflorum são na maioria irmãos completos. Em concordância, o valor estimado para o coeficiente de coancestralidade dentro de progênies $\left(\hat{\theta}_{x y}=\right.$ $0,251)$ atingiu valor próximo ao esperado para progênies de irmãos completos $(0,25)$.

Não foi detectado endogamia nas árvores maternas e nas progênies. Este resultado se contrapõe a estimativa de 5,4\% de cruzamentos entre aparentados. Era esperado, pelo menos, uma pequena taxa de endogamia nas progênies. 
Progênies de polinização aberta são, na maioria das vezes, assumidas por serem originadas de cruzamentos aleatórios, o que resultaria em progênies de meios irmãos. Os resultados observados discordam desta hipótese, mostrando que a maior parte das progênies são irmãos completos. Este resultado tem implicações importantes na estimativa de parâmetros genéticos em caracteres quantitativos. A estimativa da variância genética aditiva e parâmetros afins, como herdabilidade e ganho esperado na seleção, serão superestimados, caso as progênies sejam assumidas como meios irmãos (Squillace, 1974). Em progênies de polinização livre coletadas de populações sem endogamia e parentesco, a correlação genética entre plantas dentro de progênies $\left(r_{x y}\right)$ estima $1 / 4$ da variância genética aditiva. Porém, se ocorrerem cruzamentos biparentais, como aqui observado, a correlação $r_{x y}$, não é mais $1 / 4$. Substituindo-se os parâmetros estimados na Tabela 2, no estimador $r_{x y}$ proposto por Ritland (1989), para espécies de reprodução mista, $\left(\hat{r}_{x y}=1 / 4(1+\hat{F})\left[4 \hat{s}+\left(\hat{t}_{m}{ }^{2}+\hat{s}_{t_{m}} \hat{r}_{s}\right)\left(1+\hat{r}_{p}\right)\right]\right)$ chega-se ao valor 0,482 , que é aproximadamente $o$ dobro do esperado em progênies de meiosirmãos $(0,25)$. Ainda, como o coeficiente de correlação é duas vezes o coeficiente de coancestralidade entre plantas dentro de progênies (Falconer \& Mackay, 1997), tem-se que, $\hat{\theta}_{x y}=0,243$, valor próximo ao coeficiente de coancestralidade estimado pela análise da variância das freqüências alélicas, 0,251 (Tabela 2), confirmando-se novamente a conclusão que as progênies são predominantemente aparentados no grau de irmãos completos. Isto implica que se parâmetros genéticos fossem estimados usando o modelo aleatório (meios irmãos), incorreria-se em um erro de aproximadamente $50 \%$, nas estimativas. Portanto, neste caso, seria mais apropriado usar o modelo clássico de irmãos completos do que o de meios irmãos.

O sistema misto tem também fortes implicações na estimativa do tamanho efetivo populacional $(\mathrm{Ne})$. Por exemplo, assumindo ausência de endogamia e parentesco na geração parental e a coleta de infinitas sementes nas oito matrizes, o tamanho efetivo aproximar-se-ia de $4 \mathrm{~m}$, sendo m o número de progênies, logo, $\hat{N}_{e=}$ 32. Por outro lado, para as mesmas condições anteriores (coleta de infinitas sementes em população não endogâmica e sem parentesco), usando-se a expressão de tamanho efetivo de variância derivada por Cockerham (1969) para espécies 
hermafroditas de sistema misto, $\left.\hat{N}_{e}=0,5 /\left[\hat{\theta}_{x y}(n-1) / n\right)+\left(1+\hat{F}_{p}\right) / 2 n\right]$ em que, $\hat{\theta}_{x y}$ é o coeficiente médio de coancestralidade dentro de progênies, $n$ é o tamanho total da amostra (assumido infinito >1.000) e $\hat{F}_{p}$ é o índice de fixação nas progênies, e substituindo-se seus respectivos valores estimados na Tabela 2 , chega-se ao tamanho efetivo de 16,5. Conclui-se assim, que o tamanho efetivo estimado, considerando os parâmetros do sistema de reprodução, é aproximadamente $50 \%$ menor do que o esperado por cruzamentos aleatórios $\left(\hat{N}_{e}=32\right)$. Estes resultados mostram que é fundamental o conhecimento prévio do sistema de reprodução das espécies, em programas de melhoramento e conservação genética ex situ. Portanto, para a conservação genética de T. grandiflorum, será necessário a coleta de sementes em aproximadamente 25 árvores, para reter o tamanho efetivo de 50, valor corriqueiramente usado para a conservação à curto prazo.

\subsection{Conclusões}

A estimativa da taxa de cruzamento multilocos sugere T. grandiflorum como uma espécie perfeitamente alógama;

A comparação das freqüências alélicas dos óvulos vs pólen indica que os cruzamentos não ocorrem de forma aleatória;

A estimativa da correlação de paternidade e do coeficiente de coancestralidade dentro de progênies, indicam que as progênies são predominantemente aparentadas no grau de irmãos completos;

A utilização de estratégias de amostragem para a conservação e melhoramento genético desta população específica de T. grandiflorum devem seguir modelos para espécies de cruzamentos biparentais (irmãos completos). 


\section{CONCLUSÕES GERAIS}

Baseado nas informações geradas neste estudo, é possível emitir as seguintes conclusões:

A diversidade genética observada entre as populações coletadas no Sul e Sudeste do Pará e Noroeste do Maranhão, dá respaldo à hipótese que aponta a região como o centro de máxima diversidade do cupuaçuzeiro;

Uma lista mínima com 19 descritores botânico-agronômicos pode ser eficientemente utilizada na caracterização de populações de cupuaçuzeiro.

É sugerida a alogamia como o sistema de cruzamento preferencial do cupuaçuzeiro; 
ANEXOS 
ANEXO A -- Temperaturas de anelamento dos primers, com os respectivos número de ciclos. Na primeira etapa a temperatura decresce $1^{\circ} \mathrm{C}$ a cada ciclo. Na segunda, permanece fixa.

\begin{tabular}{|c|c|c|c|c|c|}
\hline \multirow[b]{2}{*}{ Loco } & \multicolumn{3}{|c|}{ Primeira Etapa } & \multicolumn{2}{|c|}{ Segunda Etapa } \\
\hline & $\begin{array}{l}\text { Temp inicial } \\
\left({ }^{\circ} \mathrm{C}\right)\end{array}$ & $\begin{array}{l}\text { Temp. final } \\
\left({ }^{\circ} \mathrm{C}\right)\end{array}$ & $\begin{array}{l}\text { № de } \\
\text { ciclos }\end{array}$ & Temp. $\left({ }^{\circ} \mathrm{C}\right)$ & № de ciclos \\
\hline CIR 4 & 62 & 58 & 5 & 57 & 30 \\
\hline CIR 6 & 65 & 55 & 10 & 55 & 30 \\
\hline CIR 7 & 60 & 55 & 5 & 55 & 35 \\
\hline CIR 9 & 66 & 56 & 10 & 56 & 30 \\
\hline CIR 11 & 59 & 49 & 10 & 49 & 30 \\
\hline CIR 12 & & & & 55 & 40 \\
\hline CIR 17 & 66 & 56 & 10 & 56 & 30 \\
\hline CIR 18 & 65 & 55 & 10 & 55 & 30 \\
\hline CIR 19 & & & & & \\
\hline CIR 22 & 66 & 56 & 10 & 56 & 30 \\
\hline CIR 25 & 65 & 55 & 10 & 55 & 30 \\
\hline CIR 26 & & & & & \\
\hline CIR 30 & - & & - & 55 & 40 \\
\hline CIR 31 & 60 & 55 & 5 & 55 & 35 \\
\hline CIR 33 & 66 & 56 & 10 & 56 & 30 \\
\hline CIR 43 & 60 & 55 & 5 & 55 & 35 \\
\hline CIR 45 & 60 & 55 & 5 & 55 & 35 \\
\hline CIR 48 & 60 & 55 & 5 & 55 & 35 \\
\hline CIR 54 & & & & 55 & 40 \\
\hline CIR 57 & 60 & 55 & 5 & 55 & 35 \\
\hline CIR 58 & 66 & 56 & 10 & 56 & 30 \\
\hline CIR 61 & 66 & 56 & 10 & 56 & 30 \\
\hline
\end{tabular}


ANEXO B - Comparação entre o número de alelos obtidos com a utilização de onze primers comuns de microssatélites, em cacaueiro (Lanaud et al, 1999 e Sereno, 2001) e cupuaçuzeiro do presente trabalho, originados dos acessos do BAG de cupuaçuzeiro - Belém.

\begin{tabular}{|c|c|c|c|}
\hline $\operatorname{Loco}^{a}$ & Lanaud et al, 1999 & Sereno, 2001 & Presente trabalho \\
\hline CIR 28 & 4 & 1 & 1 \\
\hline CIR 2 & 3 & 1 & $\left({ }^{*}\right)$ \\
\hline CIR 18 & 8 & 3 & 8 \\
\hline CIR 10 & 4 & 4 & $\left({ }^{\star}\right)$ \\
\hline CIR 6 & 8 & 7 & 6 \\
\hline CIR 11 & 9 & 7 & 4 \\
\hline CIR 22 & 4 & 4 & 7 \\
\hline CIR 17 & 3 & 5 & 8 \\
\hline$C I R 1$ & 3 & 6 & 1 \\
\hline CIR 7 & 6 & 3 & 4 \\
\hline CIR 12 & 10 & 8 & 3 \\
\hline TOTAL & 62 & 49 & 42 \\
\hline MÉDIA & 5,63 & 4,46 & 3,82 \\
\hline
\end{tabular}

$\left({ }^{*}\right)$ : Não amplificou. 
ANEXO C - Freqüências alélicas de sete populações de cupuaçuzeiro, sendo três naturais, três do BAG e uma coletada em áreas de produtores, por 21 locos microssatélites.

\begin{tabular}{|c|c|c|c|c|c|c|c|c|}
\hline \multirow{3}{*}{ Loco } & & \multicolumn{7}{|c|}{ POPULAÇÕES } \\
\hline & & \multicolumn{3}{|c|}{ Naturais } & \multicolumn{3}{|c|}{ BAG } & \multirow{2}{*}{$\begin{array}{l}\text { Produtores } \\
\text { Tomé-açu }\end{array}$} \\
\hline & & Tucuruí & Maranhão & N. Ipixuna & Amazonas & Pará & Amapá & \\
\hline \multicolumn{9}{|c|}{ CIR 04} \\
\hline & 1 & 0,575 & 0,762 & 0,538 & 0,204 & 0,000 & 0,000 & 0,760 \\
\hline & 2 & 0,425 & 0,237 & 0,436 & 0,741 & 1,000 & 0,714 & 0,200 \\
\hline & 3 & 0,000 & 0,000 & 0,026 & 0,056 & 0,000 & 0,286 & 0,040 \\
\hline \multicolumn{9}{|c|}{ CIRO6 } \\
\hline & 1 & 0,025 & 0,457 & 0,125 & 0,000 & 0,050 & 0,000 & 0,323 \\
\hline & 2 & 0,613 & 0,271 & 0,262 & 0,034 & 0,100 & 0,000 & 0,667 \\
\hline & 3 & 0,363 & 0,271 & 0,100 & 0,534 & 0,750 & 0,714 & 0,010 \\
\hline & 4 & 0,000 & 0,000 & 0,150 & 0,103 & 0,100 & 0,143 & 0,000 \\
\hline & 5 & 0,000 & 0,000 & 0,300 & 0,172 & 0,000 & 0,143 & 0,000 \\
\hline & 6 & 0,000 & 0,000 & 0,063 & 0,155 & 0,000 & 0,000 & 0,000 \\
\hline \multicolumn{9}{|c|}{ CIR 09} \\
\hline & 1 & 0,000 & 0,025 & 0,000 & 0,966 & 1,000 & 1,000 & 0,000 \\
\hline & 2 & 1,000 & 0,975 & 1,000 & 0,034 & 0,000 & 0,000 & 1,000 \\
\hline \multicolumn{9}{|c|}{ CIR 11} \\
\hline & 1 & 0,087 & 0,013 & 0,846 & 0,034 & 0,050 & 0,143 & 1,000 \\
\hline & 2 & 0,813 & 0,025 & 0,154 & 0,293 & 0,400 & 0,286 & 0,000 \\
\hline & 3 & 0,100 & 0,962 & 0,000 & 0,638 & 0,550 & 0,571 & 0,000 \\
\hline & 4 & 0,000 & 0,000 & 0,000 & 0,034 & 0,000 & 0,000 & 0,000 \\
\hline \multicolumn{9}{|c|}{ CIR 12} \\
\hline & 1 & 0,200 & 0,192 & 0,842 & 0,017 & 0,050 & 0,000 & 1,000 \\
\hline & 2 & 0,800 & 0,808 & 0,158 & 0,966 & 0,950 & 1,000 & 0,000 \\
\hline & 3 & 0,000 & 0,000 & 0,000 & 0,017 & 0,000 & 0,000 & 0,000 \\
\hline \multicolumn{9}{|c|}{ CIR 17} \\
\hline & 1 & 0,013 & 0,025 & 0,013 & 0,017 & 0,000 & 0,000 & 0,060 \\
\hline & 2 & 0,225 & 0,025 & 0,038 & 0,052 & 0,000 & 0,000 & 0,060 \\
\hline & 3 & 0,150 & 0,138 & 0,410 & 0,155 & 0,200 & 0,143 & 0,060 \\
\hline & 4 & 0,450 & 0,013 & 0,115 & 0,155 & 0,150 & 0,286 & 0,190 \\
\hline & 5 & 0,075 & 0,138 & 0,256 & 0,121 & 0,150 & 0,000 & 0,220 \\
\hline & 6 & 0,087 & 0,350 & 0,167 & 0,017 & 0,000 & 0,286 & 0,040 \\
\hline & 7 & 0,000 & 0,100 & 0,000 & 0,000 & 0,050 & 0,000 & 0,020 \\
\hline & 8 & 0,000 & 0,213 & 0,000 & 0,483 & 0,450 & 0,286 & 0,350 \\
\hline \multicolumn{9}{|c|}{ CIR 18} \\
\hline & 1 & 0,013 & 0,025 & 0,050 & 0,017 & 0,000 & 0,000 & 0,020 \\
\hline & 2 & 0,038 & 0,038 & 0,025 & 0,017 & 0,000 & 0,071 & 0,010 \\
\hline & 3 & 0,038 & 0,938 & 0,925 & 0,121 & 0,200 & 0,357 & 0,100 \\
\hline & 4 & 0,038 & 0,000 & 0,000 & 0,017 & 0,050 & 0,000 & 0,270 \\
\hline & 5 & 0,038 & 0,000 & 0,000 & 0,034 & 0,000 & 0,000 & 0,070 \\
\hline & 6 & 0,837 & 0,000 & 0,000 & 0,069 & 0,000 & 0,000 & 0,530 \\
\hline & 7 & 0,000 & 0,000 & 0,000 & 0,655 & 0,750 & 0,571 & 0,000 \\
\hline & 8 & 0,000 & 0,000 & 0,000 & 0,069 & 0,000 & 0,000 & 0,000 \\
\hline \multicolumn{9}{|c|}{ CIR 19} \\
\hline & 1 & 0,333 & 0,375 & 0,400 & 0,038 & 0,200 & 0,143 & 0,320 \\
\hline & 2 & 0,231 & 0,050 & 0,500 & 0,308 & 0,100 & 0,429 & 0,100 \\
\hline & 3 & 0,436 & 0,075 & 0,100 & 0,096 & 0,100 & 0,143 & 0,060 \\
\hline & 4 & 0,000 & 0,287 & 0,000 & 0,558 & 0,600 & 0,286 & 0,510 \\
\hline & 5 & 0,000 & 0,213 & 0,000 & 0,000 & 0,000 & 0,000 & 0,010 \\
\hline
\end{tabular}


ANEXO C - Freqüências alélicas de sete populações de cupuaçuzeiro, sendo três naturais, três do BAG e uma coletada em áreas de produtores, por 21 locos microssatélites.

\begin{tabular}{|c|c|c|c|c|c|c|c|}
\hline \multirow{3}{*}{ Loco } & \multicolumn{7}{|c|}{ POPULAÇŌES } \\
\hline & \multicolumn{3}{|c|}{ Naturais } & \multicolumn{3}{|c|}{ BAG } & \multirow{2}{*}{$\begin{array}{l}\text { Produtores } \\
\text { Tomé-açu }\end{array}$} \\
\hline & Tucuruí & Maranhão & N. Ipixuna & Amazonas & Pará & Amapá & \\
\hline \multicolumn{8}{|l|}{ CIR 22} \\
\hline 1 & 0,654 & 0,526 & 0,475 & 0,017 & 0,000 & 0,000 & 0,837 \\
\hline 2 & 0,295 & 0,462 & 0,112 & 0,190 & 0,200 & 0,071 & 0,153 \\
\hline 3 & 0,051 & 0,013 & 0,412 & 0,086 & 0,450 & 0,500 & 0,010 \\
\hline 4 & 0,000 & 0,000 & 0,000 & 0,379 & 0,250 & 0,429 & 0,000 \\
\hline 5 & 0,000 & 0,000 & 0,000 & 0,259 & 0,100 & 0,000 & 0,000 \\
\hline 6 & 0,000 & 0,000 & 0,000 & 0,052 & 0,000 & 0,000 & 0,000 \\
\hline 7 & 0,000 & 0,000 & 0,000 & 0,017 & 0,000 & 0,000 & 0,000 \\
\hline \multicolumn{8}{|l|}{ CIR 25} \\
\hline 1 & 0,025 & 0,275 & 0,063 & 0,069 & 0,000 & 0,000 & 0,200 \\
\hline 2 & 0,075 & 0,500 & 0,938 & 0,069 & 0,050 & 0,000 & 0,070 \\
\hline 3 & 0,250 & 0,213 & 0,000 & 0,017 & 0,050 & 0,000 & 0,150 \\
\hline 4 & 0,475 & 0,013 & 0,000 & 0,069 & 0,050 & 0,000 & 0,380 \\
\hline 5 & 0,175 & 0,000 & 0,000 & 0,017 & 0,100 & 0,071 & 0,200 \\
\hline 6 & 0,000 & 0,000 & 0,000 & 0,431 & 0,700 & 0,929 & 0,000 \\
\hline 7 & 0,000 & 0,000 & 0,000 & 0,328 & 0,050 & 0,000 & 0,000 \\
\hline \multicolumn{8}{|l|}{ CIR 26} \\
\hline 1 & 0,013 & 0,244 & 0,863 & 0,035 & 0,000 & 0,000 & 0,092 \\
\hline 2 & 0,025 & 0,231 & 0,138 & 0,035 & 0,000 & 0,000 & 0,378 \\
\hline 3 & 0,512 & 0,038 & 0,000 & 0,018 & 0,050 & 0,000 & 0,010 \\
\hline 4 & 0,450 & 0,487 & 0,000 & 0,070 & 0,050 & 0,000 & 0,520 \\
\hline 5 & 0,000 & 0,000 & 0,000 & 0,017 & 0,000 & 0,000 & 0,000 \\
\hline 6 & 0,000 & 0,000 & 0,000 & 0,052 & 0,000 & 0,000 & 0,000 \\
\hline 7 & 0,000 & 0,000 & 0,000 & 0,172 & 0,350 & 0,786 & 0,000 \\
\hline 8 & 0,000 & 0,000 & 0,000 & 0,153 & 0,050 & 0,000 & 0,000 \\
\hline 9 & 0,000 & 0,000 & 0,000 & 0,069 & 0,000 & 0,000 & 0,000 \\
\hline 10 & 0,000 & 0,000 & 0,000 & 0,379 & 0,500 & 0,214 & 0,000 \\
\hline \multicolumn{8}{|l|}{ CIR 30} \\
\hline 1 & 0,000 & 0,025 & 0,000 & 0,017 & 0,000 & 0,000 & 0,000 \\
\hline 2 & 1,000 & 0,975 & 1,000 & 0,948 & 0,900 & 1,000 & 1,000 \\
\hline 3 & 0,000 & 0,000 & 0,000 & 0,034 & 0,050 & 0,000 & 0,000 \\
\hline 4 & 0,000 & 0,000 & 0,000 & 0,000 & 0,050 & 0,000 & 0,000 \\
\hline \multicolumn{8}{|l|}{ CIR 31} \\
\hline 1 & 0,077 & 0,087 & 0,488 & 0,017 & 0,000 & 0,071 & 0,010 \\
\hline 2 & 0,051 & 0,013 & 0,013 & 0,052 & 0,100 & 0,000 & 0,080 \\
\hline 3 & 0,346 & 0,425 & 0,050 & 0,000 & 0,000 & 0,214 & 0,020 \\
\hline 4 & 0,410 & 0,425 & 0,438 & 0,052 & 0,000 & 0,000 & 0,880 \\
\hline 5 & 0,115 & 0,025 & 0,013 & 0,017 & 0,000 & 0,143 & 0,010 \\
\hline 6 & 0,000 & 0,025 & 0,000 & 0,810 & 0,900 & 0,571 & 0,000 \\
\hline 7 & 0,000 & 0,000 & 0,000 & 0,052 & 0,000 & 0,000 & 0,000 \\
\hline \multicolumn{8}{|l|}{ CIR 33} \\
\hline 1 & 0,438 & 0,325 & 0,050 & 0,655 & 0,600 & 0,429 & 0,010 \\
\hline 2 & 0,063 & 0,150 & 0,200 & 0,017 & 0,000 & 0,000 & 0,920 \\
\hline 3 & 0,500 & 0,525 & 0,013 & 0,259 & 0,350 & 0,500 & 0,070 \\
\hline 4 & 0,000 & 0,000 & 0,738 & 0,034 & 0,050 & 0,071 & 0,000 \\
\hline 5 & 0,000 & 0,000 & 0,000 & 0,034 & 0,000 & 0,000 & 0,000 \\
\hline
\end{tabular}


ANEXO C - Freqüências alélicas de sete populações de cupuaçuzeiro, sendo três naturais, três do BAG e uma coletada em áreas de produtores, por 21 locos microssatélites.

\begin{tabular}{|c|c|c|c|c|c|c|c|c|}
\hline \multirow{3}{*}{\multicolumn{2}{|c|}{ Loco }} & \multicolumn{7}{|c|}{ POPULAÇŌES } \\
\hline & & \multicolumn{3}{|c|}{ Naturais } & \multicolumn{3}{|c|}{ BAG } & \multirow{2}{*}{$\begin{array}{l}\text { Produtores } \\
\text { Tomé-açu }\end{array}$} \\
\hline & & Tucuruí & Maranhão & N. Ipixuna & Amazonas & Pará & Amapá & \\
\hline \multicolumn{9}{|l|}{ CIR 43} \\
\hline & 1 & 0,013 & 0,213 & 0,077 & 0,086 & 0,000 & 0,000 & 0,050 \\
\hline & 2 & 0,775 & 0,450 & 0,500 & 0,069 & 0,000 & 0,000 & 0,920 \\
\hline & 3 & 0,213 & 0,050 & 0,423 & 0,345 & 0,500 & 0,429 & 0,030 \\
\hline & 4 & 0,000 & 0,287 & 0,000 & 0,397 & 0,500 & 0,500 & 0,000 \\
\hline & 5 & 0,000 & 0,000 & 0,000 & 0,069 & 0,000 & 0,071 & 0,000 \\
\hline & 6 & 0,000 & 0,000 & 0,000 & 0,034 & 0,000 & 0,000 & 0,000 \\
\hline \multicolumn{9}{|l|}{ CIR 45} \\
\hline & 1 & 0,975 & 1,000 & 0,875 & 0,810 & 0,950 & 1,000 & 1,000 \\
\hline & 2 & 0,025 & 0,000 & 0,125 & 0,121 & 0,050 & 0,000 & 0,000 \\
\hline & 3 & 0,000 & 0,000 & 0,000 & 0,069 & 0,000 & 0,000 & 0,000 \\
\hline \multicolumn{9}{|c|}{ CIR 48} \\
\hline & 1 & 0,921 & 0,925 & 0,013 & 0,552 & 0,550 & 0,571 & 0,060 \\
\hline & 2 & 0,039 & 0,025 & 0,825 & 0,414 & 0,300 & 0,429 & 0,920 \\
\hline & 3 & 0,039 & 0,050 & 0,162 & 0,034 & 0,150 & 0,000 & 0,020 \\
\hline \multicolumn{9}{|l|}{ CIR 54} \\
\hline & 1 & 0,846 & 0,789 & 1,000 & 0,052 & 0,000 & 0,071 & 0,350 \\
\hline \multirow{2}{*}{\multicolumn{9}{|c|}{ CIR 57}} \\
\hline & & & & & & & & \\
\hline & 1 & 0,789 & 0,141 & 0,705 & 0,103 & 0,300 & 0,286 & 0,110 \\
\hline & 2 & 0,211 & 0,410 & 0,192 & 0,155 & 0,350 & 0,143 & 0,160 \\
\hline & 3 & 0,000 & 0,192 & 0,103 & 0,448 & 0,200 & 0,357 & 0,730 \\
\hline & 4 & 0,000 & 0,256 & 0,000 & 0,224 & 0,150 & 0,143 & 0,000 \\
\hline & 5 & 0,000 & 0,000 & 0,000 & 0,069 & 0,000 & 0,071 & 0,000 \\
\hline \multicolumn{9}{|l|}{ CIR 58} \\
\hline & 1 & 0,112 & 0,038 & 0,325 & 0,241 & 0,200 & 0,071 & 0,070 \\
\hline & 2 & 0,387 & 0,463 & 0,175 & 0,759 & 0,800 & 0,929 & 0,440 \\
\hline & 3 & 0,050 & 0,038 & 0,325 & 0,000 & 0,000 & 0,000 & 0,020 \\
\hline & 4 & 0,450 & 0,463 & 0,175 & 0,000 & 0,000 & 0,000 & 0,470 \\
\hline \multicolumn{9}{|l|}{ CIR 61} \\
\hline & 1 & 0,064 & 0,014 & 0,026 & 0,069 & 0,100 & 0,071 & 0,021 \\
\hline & 2 & 0,244 & 0,236 & 0,053 & 0,053 & 0,000 & 0,358 & 0,031 \\
\hline & 3 & 0,205 & 0,083 & 0,026 & 0,086 & 0,150 & 0,000 & 0,071 \\
\hline & 4 & 0,321 & 0,056 & 0,053 & 0,224 & 0,200 & 0,000 & 0,276 \\
\hline & 5 & 0,167 & 0,139 & 0,395 & 0,207 & 0,050 & 0,143 & 0,071 \\
\hline & 6 & 0,000 & 0,167 & 0,395 & 0,155 & 0,250 & 0,071 & 0,020 \\
\hline & 7 & 0,000 & 0,139 & 0,026 & 0,069 & 0,150 & 0,071 & 0,153 \\
\hline & 8 & 0,000 & 0,014 & 0,026 & 0,034 & 0,000 & 0,143 & 0,235 \\
\hline & 9 & 0,000 & 0,152 & 0,000 & 0,069 & 0,000 & 0,000 & 0,112 \\
\hline & 10 & 0,000 & 0,000 & 0,000 & 0,017 & 0,050 & 0,143 & 0,010 \\
\hline & 11 & 0,000 & 0,000 & 0,000 & 0,017 & 0,050 & 0,000 & 0,000 \\
\hline
\end{tabular}


ANEXO D - Verificação da aderência ao Equilíbrio de Hardy-Weinberg (EHW), usando o teste exato de Fisher, e ao Equilíbrio de Endogamia de Wright (EEW), pelo teste de Qui-quadrado $\left(\chi^{2}\right)$, em três populações de do BAG de cupuaçuzeiro.

\begin{tabular}{|c|c|c|c|c|c|c|}
\hline \multirow[t]{2}{*}{ Loco } & \multicolumn{2}{|c|}{ Amazonas } & \multicolumn{2}{|c|}{ Pará } & \multicolumn{2}{|c|}{ Amapá } \\
\hline & EHW & EEW & EHW & EEW & EHW & EEW \\
\hline CIR 04 & $0.000(3)$ & $18,46^{\star *} \quad(2)$ & $\left({ }^{a}\right)$ & - & $0.021(1)$ & $\left({ }^{b}\right)$ \\
\hline CIR O6 & 0.008 (10) & 23,60 ns (14) & $0.433(6)$ & - & 0.021 (3) & $3,07 \mathrm{~ns}$ (2) \\
\hline CIR 09 & $1.000(1)$ & - & $\left({ }^{\mathrm{a}}\right)$ & - & $\left({ }^{a}\right)$ & - \\
\hline CIR 11 & 0.001 ( 6 ) & $9,13 \mathrm{~ns}$ & $1.000(3)$ & - & 0.429 (3) & - \\
\hline CIR 12 & $1.000(3)$ & - & $1,000(1)$ & - & $\left({ }^{a}\right)$ & - \\
\hline CIR 17 & $0.134(21)$ & - & $0.232(10)$ & - & $0.022(6)$ & 8,61 ns (5) \\
\hline CIR 18 & 0.687 ( 28) & - & $1.000(3)$ & - & $0.161(3)$ & - \\
\hline CIR 19 & $0.022(6)$ & 8,17 ns & $0.002(6)$ & $18,79^{\star *}$ & $0.440(6)$ & - \\
\hline CIR 22 & $0.044(21)$ & 12,91 ns (20) & $0.232(6)$ & - & 0.119 (3) & - \\
\hline CIR 25 & $0.008(21)$ & $33,40^{*}(20)$ & $1.000(15)$ & - & $1.000(1)$ & - \\
\hline CIR 26 & 0.062 ( 28$)$ & - & $0.564(10)$ & - & $0.231(1)$ & - \\
\hline CIR 30 & $0.053(3)$ & - & $1.000(3)$ & - & $\left({ }^{a}\right)$ & - \\
\hline CIR 31 & 0.238 ( 15) & - & $1,000(1)$ & - & $0.161(6)$ & - \\
\hline CIR 33 & 0.225 ( 10$)$ & - & $1.000(3)$ & - & 0.918 (3) & - \\
\hline CIR 43 & 0.016 ( 15) & $138,40^{\star *}(14)$ & 0,007 (1) & $\left({ }^{b}\right)$ & 0.037 (3) & $11,77^{\star \star}(2)$ \\
\hline CIR 45 & $0.238(3)$ & - & $1,000(1)$ & - & $\left({ }^{a}\right)$ & - \\
\hline CIR 48 & 0.000 ( 3$)$ & $35,19^{* *} \quad(2)$ & $0.045(3)$ & $8,08^{*}(2)$ & 0.161 (1) & - \\
\hline CIR 54 & $0.053(1)$ & - & $\left({ }^{a}\right)$ & - & $1.000(1)$ & - \\
\hline CIR 57 & 0.000 (10) & $25,66^{* *} \quad(9)$ & $1.035(6)$ & - & $0.172(10)$ & - \\
\hline CIR 58 & $0.029(1)$ & $\left({ }^{b}\right)$ & 0,297 1) & - & $1.000(1)$ & - \\
\hline CIR 61 & 0.001 ( 28$)$ & $101,26^{*}(54)$ & $0.742(15)$ & - & $0.508(15)$ & - \\
\hline
\end{tabular}


ANEXO E - Verificação da aderência ao Equilíbrio de Hardy-Weinberg (EHW), usando o teste exato de Fisher, e ao Equilíbrio de Endogamia de Wright (EEW), pelo teste de Qui-quadrado $\left(\chi^{2}\right)$, em quatro populações de cupuaçuzeiro.

\begin{tabular}{|c|c|c|c|c|c|c|c|c|}
\hline \multirow[t]{2}{*}{ Loco } & \multicolumn{2}{|c|}{ Tucuruí } & \multicolumn{2}{|c|}{ Maranhão } & \multicolumn{2}{|c|}{ Nova Ipixuna } & \multicolumn{2}{|c|}{ Tomé-açu } \\
\hline & EHW & EEW & EHW & EEW & EHW & EEW & EHW & EEW \\
\hline CIR04 & $0,10(1)$ & - & $0,66(1)$ & - & $0.00(3)$ & $\begin{array}{l}38,2^{* *} \\
(2)\end{array}$ & $0.00(3)$ & $41,4^{* \star}(2)$ \\
\hline CIR O6 & 0,19 (3) & - & 0,09 (3) & - & $0.12(15)$ & - & $0.00(3)$ & $17,2^{\star *}(2)$ \\
\hline CIR 09 & $\left({ }^{a}\right)$ & - & $1,00(1)$ & - & & - & $\left({ }^{\mathrm{a}}\right)$ & - \\
\hline CIR 11 & $0,02(3)$ & $8,1^{*}(2)$ & 1,00 (3) & & $0.20(1)$ & - & $\left({ }^{a}\right)$ & - \\
\hline CIR 12 & $0,03(1)$ & $\left({ }^{b}\right)$ & $0,02(1)$ & $\left({ }^{b}\right)$ & $0.56(1)$ & - & $\left(a^{a}\right)$ & - \\
\hline CIR 17 & $0,22(15)$ & - & $0,01(28)$ & $\begin{array}{l}26,6 \quad n s \\
(27)\end{array}$ & $0.34(15)$ & - & $0.55(28)$ & - \\
\hline CIR 18 & $1,00(15)$ & - & $1,00(3)$ & - & $0.18(3)$ & - & $0.39(15)$ & - \\
\hline CIR 19 & $0,00(3)$ & $21,9^{* *}(2)$ & 1,00 (10) & - & $0.54(3)$ & - & $0.02(10)$ & $26,8^{\star *}(9)$ \\
\hline CIR 22 & $0,00(3)$ & $9,9^{* *}(2)$ & $0,00(3)$ & $18,2^{* \star}(2)$ & $0.22(3)$ & 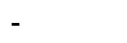 & $0.00(3)$ & $7,6^{*}(2)$ \\
\hline CIR 25 & $0,00(10)$ & $51,0^{* *}(9)$ & $0,00(6)$ & $56,9^{* *}(5)$ & $0.12(1)$ & - & $0.03(10)$ & $\begin{array}{l}15,0 \text { ns } \\
(9)\end{array}$ \\
\hline CIR 26 & $0,00 \quad(6)$ & $17,3^{\star *}(5)$ & $0,34(6)$ & 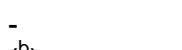 & 0.545 (1) & - & $0.39(6)$ & - \\
\hline CIR 30 & $\left({ }^{a}\right)$ & & $0,02(1)$ & $\left({ }^{b}\right)$ & & - & $\left({ }^{a}\right)$ & - \\
\hline CIR 31 & $0,11(10)$ & - & 0,00 (15) & $25,7^{*}(14)$ & $0.35(10)$ & - & $0.01(10)$ & $28,3^{\star *}(9)$ \\
\hline CIR 33 & $0,00(3)$ & $10,3^{* *}(2)$ & $0,06(3)$ & - & $0.70(6)$ & - & $0.26(3)$ & - \\
\hline CIR 43 & $0,65(3)$ & - & $0,00(6)$ & $71,5^{\star \star}(5)$ & 0.00 (3) & $\begin{array}{l}46,7^{* *} \\
(2)\end{array}$ & $1.00(3)$ & - \\
\hline CIR 45 & $0,01(1)$ & $\left({ }^{b}\right)$ & $\left({ }^{a}\right)$ & - & 0.09 (1) & - & $\left(^{\mathrm{a}}\right)$ & - \\
\hline CIR 48 & $0,19(3)$ & - & 0,18 (3) & & 0.07 (3) & - & $0.00(3)$ & $15,0^{* *}(2)$ \\
\hline CIR 54 & $0,56(1)$ & - & $0.00(1)$ & $\left(^{b}\right)$ & $\left({ }^{a}\right)$ & - & $0.00(1)$ & - \\
\hline CIR 57 & $0,32(1)$ & - & $0.00(6)$ & $24,3^{* *}(5)$ & $0.00(3)$ & $\begin{array}{l}25,3^{* *} \\
(2)\end{array}$ & $0.30(3)$ & - \\
\hline CIR 58 & $0,00(6)$ & $97,8^{\star *}(5)$ & $0.00(6)$ & $151,6^{* *}(5)$ & $0.00(6)$ & $\begin{array}{l}138,2^{\star *} \\
(5)\end{array}$ & $0.00(6)$ & $94,2^{* *}(5)$ \\
\hline CIR 61 & $0,27(10)$ & - & $1.00(28)$ & - & $0.00(28)$ & $\begin{array}{l}60,2^{* *} \\
(44)\end{array}$ & $0.74(28)$ & - \\
\hline
\end{tabular}

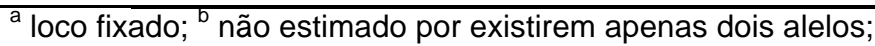

* significativo pelo teste de Qui-quadrado ao nível de 5\% de significância. 
ANEXO F. Média, Desvio Padrão, Teste $F, R^{2}$ e Coeficiente de Variação (\%), referentes a descritores de folha, flor, fruto e agronômicos, utilizados no BAG de cupuaçuzeiro.

\begin{tabular}{|c|c|c|c|c|c|c|}
\hline Descritor & & Média & D. Padrão & $\mathrm{F}$ & $\mathrm{R}^{2}$ & CV (\%) \\
\hline \multirow[t]{14}{*}{ Folha: } & CF $(\mathrm{cm})$ & 28,55 & 2,17 & $7,89^{\star \star}$ & 0,79 & 7,59 \\
\hline & LLBASE $(\mathrm{cm})$ & 7,35 & 0,68 & $9,35^{\star *}$ & 0,82 & 9,27 \\
\hline & LLMEIO (cm) & 9,02 & 0,73 & $13,14^{* *}$ & 0,86 & 8,12 \\
\hline & LLTOPO $\mathrm{cm}$ ) & 8,17 & 0,62 & $11,35^{\star *}$ & 0,84 & 7,61 \\
\hline & $\mathrm{CPF}(\mathrm{cm})$ & 1,71 & 0,31 & $1,71^{*}$ & 0,45 & 17,95 \\
\hline & $\mathrm{DPF}(\mathrm{cm})$ & 4,50 & 0,49 & $6,06^{* *}$ & 0,74 & 10,86 \\
\hline & $\mathrm{EL}(\mu \mathrm{m})$ & 28,87 & 2,64 & $7,45^{\star *}$ & 0,78 & 9,16 \\
\hline & $\mathrm{CA}(\mathrm{mm})$ & 3,76 & 0,30 & $9,74^{\star *}$ & 0,82 & 8,00 \\
\hline & $\mathrm{LA}(\mathrm{mm})$ & 1,00 & 0,19 & $2,93^{* *}$ & 0,59 & 18,63 \\
\hline & ANB $\left({ }^{\circ}\right)$ & 43,01 & 2,57 & $3,57^{* *}$ & 0,63 & 5,97 \\
\hline & ANM $(\stackrel{0}{)}$ & 47,98 & 4,04 & $3,53^{\star *}$ & 0,63 & 8,42 \\
\hline & ANT $(\stackrel{\circ}{)}$ & 47,37 & 4,77 & $3,39^{* *}$ & 0,62 & 10,06 \\
\hline & $\mathrm{DN}(\mathrm{cm})$ & 7,25 & 0,52 & $2,24^{\star \star}$ & 0,52 & 7,20 \\
\hline & NPN & 9,03 & 0,59 & $8,79^{* *}$ & 0,81 & 6,58 \\
\hline \multirow[t]{18}{*}{ Flor: } & $\mathrm{CBE}(\mathrm{mm})$ & 14,39 & 0,72 & $6,64^{\star *}$ & 0,76 & 5,03 \\
\hline & $\mathrm{DBE}(\mathrm{mm})$ & 12,94 & 0,66 & $4,98^{* *}$ & 0,71 & 5,11 \\
\hline & TFL (mm) & 29,38 & 1,40 & $6,03^{* *}$ & 0,74 & 4,79 \\
\hline & $\mathrm{DEA}(\mathrm{mm})$ & 5,21 & 0,31 & $3,59^{\star *}$ & 0,63 & 5,88 \\
\hline & $\mathrm{CP}(\mathrm{mm})$ & 15,77 & 2,47 & $2,72^{\star \star}$ & 0,57 & 15,64 \\
\hline & $\mathrm{DP}(\mathrm{mm})$ & 2,20 & 0,14 & $2,81^{* *}$ & 0,58 & 6,19 \\
\hline & CES (mm) & 2,26 & 0,17 & $3,64^{* *}$ & 0,64 & 7,72 \\
\hline & $\mathrm{CO}(\mathrm{mm})$ & 2,08 & 0,11 & $2,11^{\star *}$ & 0,50 & 5,20 \\
\hline & $\mathrm{DO}(\mathrm{mm})$ & 1,98 & 0,12 & $2,05^{\star *}$ & 0,50 & 6,30 \\
\hline & NO & 47,56 & 2,47 & $4,77^{\star \star}$ & 0,70 & 2,59 \\
\hline & VGP (\%) & 94,51 & 2,52 & $2,28^{\star *}$ & 0,52 & 6,77 \\
\hline & $\mathrm{CLS}(\mathrm{mm})$ & 17,52 & 1,17 & $2,42^{* *}$ & 0,54 & 6,70 \\
\hline & LLS (mm) & 8,07 & 0,53 & $3,51^{* *}$ & 0,63 & 6,54 \\
\hline & $\operatorname{CLP}(\mathrm{mm})$ & 7,17 & 0,59 & $3,12^{\star \star}$ & 0,60 & 8,24 \\
\hline & $\operatorname{LLP}(\mathrm{mm})$ & 7,55 & 0,62 & $5,07^{* *}$ & 0,71 & 8,20 \\
\hline & $\mathrm{CC}(\mathrm{mm})$ & 6,31 & 0,41 & $4,88^{\star *}$ & 0,70 & 6,45 \\
\hline & $\mathrm{LC}(\mathrm{mm})$ & 5,54 & 0,49 & $3,69^{\star *}$ & 0,64 & 8,82 \\
\hline & $\mathrm{CE}(\mathrm{mm})$ & 15,32 & 1,12 & $5,30^{* *}$ & 0,72 & 7,17 \\
\hline \multirow[t]{16}{*}{ Fruto: } & DL & 190,49 & 16,48 & $11,61^{* *}$ & 0,85 & 8,65 \\
\hline & DT & 115,22 & 4,18 & $10,19^{\star *}$ & 0,84 & 3,62 \\
\hline & PFR & 1256,09 & 182,12 & $8,16^{* *}$ & 0,80 & 14,50 \\
\hline & PCA & 543,42 & 82,34 & $6,85^{\star \star}$ & 0,77 & 15,15 \\
\hline & PPO & 498,64 & 86,23 & $8,83^{\star \star}$ & 0,82 & 17,29 \\
\hline & PSE & 187,02 & 26,68 & $7,84^{* *}$ & 0,80 & 14,26 \\
\hline & ECA & 6,02 & 0,93 & $4,33^{\star *}$ & 0,68 & 15,41 \\
\hline & ES & 12,64 & 1,11 & $3,71^{\star *}$ & 0,65 & 8,76 \\
\hline & DLS & 26,52 & 1,12 & $8,11^{* *}$ & 0,80 & 4,24 \\
\hline & DTS & 22,03 & 1,11 & $4,79^{\star *}$ & 0,70 & 5,06 \\
\hline & SN & 30,19 & 4,54 & $1,91^{*}$ & 0,49 & 7,76 \\
\hline & SC & 0,64 & 0,81 & $1,14 \mathrm{~ns}$ & 0,36 & 63,84 \\
\hline & $A C$ & 2,22 & 0,26 & $7,04^{* *}$ & 0,78 & 11,83 \\
\hline & BRIX & 12,70 & 1,29 & $3,32^{\star *}$ & 0,63 & 10,13 \\
\hline & $\mathrm{pH}$ & 3,49 & 0,67 & $0,93 \mathrm{~ns}$ & 0,32 & 19,29 \\
\hline & UM & 82,90 & 2,03 & $3,90^{\star *}$ & 0,67 & 2,45 \\
\hline \multirow[t]{5}{*}{ Agronômicos } & PROD & 9,22 & 6,92 & $4,99^{\star *}$ & 0,47 & 48,24 \\
\hline & BOTAO & 96,03 & 104,81 & $13,93^{\star *}$ & 0,62 & 49,95 \\
\hline & FLOR & 739,20 & 723,02 & $15,77^{\star *}$ & 0,66 & 46,64 \\
\hline & FRUIMA & 6,15 & 13,65 & $5,22^{* *}$ & 0,52 & 99,87 \\
\hline & NV & 45,31 & 51,39 & $50,97^{\star *}$ & 0,82 & 41,37 \\
\hline
\end{tabular}

${ }^{*} p \geq 0,05 ;{ }^{* *} p \geq 0,01$. 


\section{REFERÊNCIAS BIBLIOGRÁFICAS}

ADDISON, G.O.; TAVARES, R.M. Observações sobre as espécies do gênero Theobroma que ocorrem na Amazônia. Belém: Instituto Agronômico do Norte, 1951. 18p. (Boletim Técnico, 25)

AKKAYA, M.S.; BHAGWAT, A.A.; CREGAN, P.B. Length polymorphisms of simple sequence repeat DNA in soybean. Genetics, v.132, p.1131-1139, 1992.

ALLARD, R.W. Princípios do melhoramento genético de plantas. Rio de Janeiro: USAID, 1971. 331p.

ALVERSON, W.S.; WHITLOCK, B.A.; NYFFELER, R.; BAYER, C.; BAUM, D.A. Phylogeny of the core Malvales: evidence from ndhF sequence data. American Journal of Botany, v.89, p.1474-1486, 1999.

ALVES, R.M.; OLIVEIRA, R.P. de; LIMA, R.R.; NEVES, M.P; CHAVES, J.P.; ARAÚJO, D.G. de; PIMENTEL, L. Pesquisas com recursos genéticos e melhoramento do cupuaçuzeiro, em desenvolvimento na Embrapa/CPATU. In: WORKSHOP SOBRE AS CULTUURAS DA PUPUNHA E CUPUAÇÚ, 1., Manaus, 1996, Anais. Manaus: Embrapa, CPAA, 1996. p.127-135. (Documento, 6)

ALVES, R.M.; ARAUJO, D.G.; FERNANDES, J.R.Q. Compatibilidade entre clones de cupuaçuzeiro (Theobroma grandiflorum). Revista Brasileira de Genética, v.20, n.3, p.148, 1997a. Suplemento. /Apresentado ao 43. Congresso Nacional de Genética, Goiânia, 1997 - Resumo/

ALVES, R.M.; ARAUJO, D.G.; LOUREIRO, M.E.S.T.; FERNANDES, G.L. da C. Caracterização foliar do cupuaçuzeiro (Theobroma grandiflorum); Definição de descritores e caracterização de acessos. In: SIMPÓSIO LATINO-AMERICANO DE RECURSOS GENÉTICOS VEGETAIS, 1., Campinas, 1997. Resumos. Campinas: Embrapa, Cenargen, 1997b. p.66-67.

ALVES, R.M.; CORRÊA, J.R.V.; RODRIGO, M. Melhoramento genético do cupuaçuzeiro (Theobroma grandiflorum) no Estado do Pará. In: SEMINÁRIO INTERNACIONAL SOBRE PIMENTA-DO-REINO E CUPUAÇU, 1., Belém, 1996. Anais. Belém: EMBRAPA, CPATU/JICA, 1997c. p.127-146. (Documentos, 88) 
ALVES, R.M.; CORRÊA, J.R.V.; GOMES, M.R.O. Avaliação preliminar de matrizes de cupuaçuzeiro (Theobroma grandiflorum) em áreas de produtores de Tomé-Açu, Pará. In: ENCONTRO DE GENÉTICA DO NORDESTE, 13., Feira de Santana, 1998. Resumos. Feira de Santana: Sociedade Brasileira de Genética, Seção Nordeste, 1998a. p.359.

ALVES, R.M.; HUHN, S.; LOUREIRO, M. do E.S.T Caracterização de acessos de cupuaçuzeiro através de caracteres bromatológicos da polpa do fruto (resultados preliminares). Genetics and Molecular Biology, v.21, n.3, p.202, $1998 \mathrm{~b}$. Supplement. /Apresentado ao 44. Congresso Nacional de Genética, Águas de Lindóia, 1998 - Resumo/

ALVES, R.M.; HUHN, S.; LOUREIRO, M. do E.S.T Caracterização de acessos de cupuaçuzeiro através de caracteres bromatológicos da polpa do fruto. Belém: Embrapa Amazônia Oriental, 1998c. 4p. (Pesquisa em Andamento, 200)

ALVES, R.M.; LOUREIRO, M. do E.S.T.; FERNANDES, G.L.C. Caracterização de acessos de cupuaçuzeiro através de componentes florais. Genetics and Molecular Biology, v.21, n.3, p.203, 1998d. Supplement. /Apresentado ao 44. Congresso Nacional de Genética, Águas de Lindóia, 1998 - Resumo/

ALVES, R.M.; STEIN, R.L.B.; ARAÚJO, D.G. de; PIMENTEL, L. Avaliação de clones de cupuaçuzeiro quanto à resistência a vassoura-de-bruxa. Revista Brasileira de Fruticultura, v.20, n.3, p.297-306, 1998e.

ALVES, R.M. Banco ativo de fruteiras nativas da região norte. In: WORKSHOP PARA CURADORES DE BANCO DE GERMOPLASMA DE ESPÉCIES FRUTÍFERAS, 1., Brasília, 1997. Anais. Brasília: Embrapa Recursos Genéticos e Biotecnologia, 1999a. p.135-137.

ALVES, R.M. Cupuaçuzeiro (Theobroma grandiflorum Willd. ex. Spreng) Schum). In: EMBRAPA, Centro de Pesquisa Agroflorestal da Amazônia Oriental. Programa de melhoramento genético e de adaptação de espécies vegetais para a Amazônia Oriental. Belém, 1999b. cap.1, p.37-48 (Documentos, 16)

ALVES, R.M.; MARQUES, L.C.T.; FERREIRA, C.A.P.; FERNANDES, G.L.C.; SOUZA, L.P. Avaliação preliminar de clones de cupuaçuzeiro em área com acentuado déficit hídrico, utilizando o sistema "cabruco". Belém: Embrapa Amazônia Oriental, 1999c. 4p. (Comunicado Técnico, 104)

ALVES, R.M.; FIGUEIRA, A.V.O.; CRUZ, E.D. Estudo da variabilidade genética entre clones de cupuaçuzeiro, Theobroma grandiflorum (Willd ex Spreng) Schum, através de marcadores microssatélites. In: SIMPÓSIO DE RECURSOS GENÉTICOS PARA A AMÉRICA LATINA E CARIBE, 3., Londrina, 2001. Anais. Londrina: IAPAR/Embrapa Recursos Genéticos e Biotecnologia, 2001. p.206-208.

ALVES, R.M.; FIGUEIRA, A. Cupuassu (Theobroma grandiflorum) genetic resources and breeding in the Brasilian Amazon. Ingenic Newsletter, v.7, p.25-32, 2002.

AMALRAJ, S.F.A. Genetic divergence in Gossypium barbadense L. Genetica Agraria, v.36, n.1/2, p.23-30, 1982. 
AMARAL JÚNIOR, A.T. Análise multivariada e isozimática da divergência genética entre acessos de moranga (Cucurbita maxima Duchesne). Viçosa, 1994. 95p. Dissertação (Mestrado) - Universidade Federal de Viçosa.

ANEJA, M.; GIANFAGNA, T.; NG, E.; BADILLA, I. Carbon-dioxide treatment partially overcomes self-incompatibility in a cacao genotype. Hortscience, v.29, p.15-17, 1994.

ARAUJO, D.G.; ALVES, R.M. Avaliação da fenologia do cupuaçuzeiro (Theobroma grandiflorum) para utilização no melhoramento genético. In: SEMINÁRIO DE INICIAÇÃO CIENTÍFICA, 5., Belém, 1995. Anais. Belém: EMBRAPA, CPATU/FCAP, 1995. p.151.

ARAUJO, D.G.; CARVALHO, S.P.; ALVES, R.M. Divergência genética entre clones de cupuaçuzeiro (Theobroma grandiflorum Willd ex Spreng Schum). Ciência e Agrotecnologia, v.26, n.1, p.13-21, 2002.

BAKER, H.G. Reprodutive methods as factors in speciation inflowering plants. Cold Spring Harbor Symposia on Quantitative Biology, v.24, p.177-91, 1959.

BARBOSA, W.C.; NAZARÉ, R.F.R.; NAGATA, I. Estudos tecnológicos de frutas da Amazônia. Belém: EMBRAPA, CPATU, 1978. 19p. (Comunicado Técnico, 3)

BARROS, L.M. Caracterização morfológica e isoenzimática do cajueiro. Piracicaba, 1991. 256p. Tese (Doutorado) - Escola Superior de Agricultura "Luiz de Queiroz", Universidade de São Paulo.

BASTOS, C.N.; BENCHIMOL, R.L.; ALVES, R.M. Utilização da seiva para avaliação da resistência de clones de cupuaçuzeiro à vassoura-de-bruxa. Belém: Embrapa Amazônia Oriental, 1999. 14p. (Boletim de Pesquisa, 4)

BAWA, K.S. Breeding systems of tree species of a lowland tropical community. Evolution, v.28, p.85-92, 1974.

BEALE, E.M.L.; KENDALL, M.G.; MANN, D.W. The discarting of variables in multivariate analysis. Biometrika, v.54, p.357-365, 1967.

BEKELE, F.L.; KENNEDY, A.J.; McDAVID, C.; LAUCKNER, F.B.; BEKELE, I. Numeral taxonomic studies on cacao (Theobroma cacao L.) in Trinidad. Euphytica, v.75, p.231-240, 1994.

BEKELE, F.L.; BEKELE, I. A sampling of the phenetic diversity of cacao in the Theoretical and Applied Genetics Gene Bank of Trinidad. Crop Science, v.36, p.5764, 1996.

BROWN, A.H.D. Isozymes, plant population genetic structure and genetic conservation. Theoretical and Applied Genetics, v.52, p.145-57, 1978.

BROWN, A.H.D; BURDON, J.J.; JAROSZ, A.M. Isozyme analysis of plant mating systems. In: DOUGLAS, E.S.; SOLTIS, P.S. (Ed.). Isozymes in plant biology. London: Chapman and Hall, 1989. p. 73-86. 
BUCKLEY, D.P.; O'MALLEY, D.M.; APSIT, V.S.; PRANCE, G.T.; BAWA, K.S. Genetics of Brazil nut. (Bertholletia excelsa, Humb \& Bonpl.; Lecythidaceae): 1. Genetic variation in natural populations. Theoretical and Applied Genetics, v.76, p.923-28, 1988.

BULLOCK, S.H. Breeding systems in the flora of Tropical Deciduous Forest in Mexico. Biotropica, v.17, p.287-301, 1985.

BUTCHER, P.A.; DECROOCQ, S.; GRAY, Y.; MORAN, G.F. Development, inheritance and cross-species amplification of microsatellite markers from Acacia mangium. Theoretical and Applied Genetics, v.101, p.1282-1290, 2000.

BYRNE, M.; MARQUEZ-GARCIA, M.I.; UREN, T.; SMITH, D.S.; MORAN, G.F. Conservation of genetic diversity of microsatellite loci in the genus Eucalyptus. Australian Journal of Botany, v.44, p.331-341, 1996.

CALZAVARA, B.B.G.; MULLER, C.H.; KAHWAGE, O.N.C. Fruticultura tropical: o cupuaçuzeiro - cultivo, beneficiamento e utilização do fruto. Belém: EMBRAPA, CPATU, 1984. 101p. (Documentos, 32)

CARLETTO, G.M. O número de cromosômios em cacaueiros. Ilhéus: Instituto de Cacau da Bahia, 1946. p.35-39. (Boletim Técnico, 6)

CARTHEW, S.M. Population genetic structure of Banksia spinulosa. Heredity, v.70, n.6, p.566-573, 1993.

CARVALHO, J.E.U.; MÜLLER, C.H.; BENCHIMOL, R.L.; KATO, A.K.; ALVES, R.M. COPOASU [Theobroma grandiflorum (Willd. ex Spreng.) Schum.]: cultivo y utilización: manual tecnico. Caracas: FAO, Tratado de Cooperacion Amazonica, 1999. 152p.

CAVALCANTE, P.B. Frutas comestíveis da Amazônia. Belém: Edições CEJUP/Museu Paraense Emílio Goeldi, 1991. 279p.

CAVALCANTE, A.S.L.; COSTA, J.G. Situação atual e perspectivas da cultura do cupuaçuzeiro no estado do Acre, Amazônia ocidental brasileira. In: SEMINÁRIO INTERNACIONAL SOBRE PIMENTA-DO-REINO E CUPUAÇU, 1., Belém, 1996. Anais. Belém: EMBRAPA, CPATU/JICA, 1997. p.119-124. (Documentos, 89)

CHAAR, J.M. Composição do cupuaçu (Theobroma grandiflorum Schum.) e conservação de seu néctar por meios físicos e químicos. Rio de Janeiro, 1980. 87p. Dissertação (Mestrado) - Universidade Federal do Rio de Janeiro.

CHASE, M.R.; MOLLER, C.; KESSELI, R.; BAWA, K.S. Long distance gene flow in a fragmented tropical tree population. Nature, v.123, p.127-132, 1996.

CHELIAK; W.M.; PITTEL, J.A. Techniques for starch gel eletrophoresis of enzymes from forest treee species. Information Report, v.42, p.1-49, 1984.

CLEGG, M.T. Measuring plant mating systems. Bioscience, v.30, n.12, p.814-818, 1980. 
CLEMENT, C.R. A conservação in situ das fruteiras da amazônia. In: SIMPÓSIO LATINO-AMERICANO DE RECURSOS GENÉTICOS VEGETAIS, 1., Campinas, 1997. Resumos. Campinas: EMBRAPA, Cenargen, 1997. p.5-6.

CLEMENT, C.R. 1942 and the loss of Amazonian crop genetic resources. I. The relation between domestication and human population decline. Economic Botany, v.53, n.2, p.188-202, 1999.

COCKERHAM, C.C. Variance of gene frequencies. Evolution, v.23, p.72-84, 1969.

COLLEVATTI, R.G.; GRATTAPAGLIA, D.; HAY, J.D. Population genetic structure of the endangered tropical tree species Caryocar brasiliense, based on variability at microsatellite loci. Molecular Ecology, v.10, p.349-356, 2001.

CONDIT, R.; HUBBELL, S.P. Abundance and DNA sequence of two-base repeat regions in tropical tree genomes. Genome, v.34, p.66-71, 1991.

CONTI, J.H. Estudo de caracteres morfológicos, agronômicos e moleculares em cultivares do morango (Fragaria $x$ ananassa Duch.). Piracicaba, 1998. 154p. Tese (Doutorado) - Escola Superior de Agricultura "Luiz de Queiroz", Universidade de São Paulo.

COPE, F.W. Some factors controlling the yield of young cocoa II. In: ANNUAL REPORT ON COCOA RESEARCH, 8., Trinidad, 1938. Anais. 1938. p.4-15.

COPE, F.W. The mechanism of pollen incompatibility in Theobroma cacao L. Heredity, v.17, p.157-182, 1962.

CRESTANA, C.S.M.; DIAS; I.S.; KAGEYAMA, P.Y. Biologia floral do Guarantã (Esenbeckia leiocarpa Engl.). Silvicultura, v.28, p.35-38, 1982. /Apresentado ao 4. Congresso Florestal Brasileiro, Belo Horizonte, 1982/

CRESTE, S.; TULMANN-NETO, A.; FIGUEIRA, A. Detection of single sequence repeat polymorphisms in denaturing polyacrylamide sequencing gels by silver staining. Plant Molecular Biology Reporter, v.19, p.299-306, 2001.

CRUZ, C.D. Algumas técnicas multivariadas no melhoramento de plantas. Piracicaba: ESALQ, Depto. Genética, 1987. 75p.

CRUZ, C.D. Aplicação de algumas técnicas multivariadas no melhoramento de plantas. Piracicaba, 1990. 188p. Tese (Doutorado) - Escola Superior de Agricultura "Luiz de Queiroz", Universidade de São Paulo.

CRUZ, C.D. Programa GENES: aplicativo computacional em genética e estatística. Viçosa: UFV, 1997. 442p.

CRUZ, C.D.; REGAZZI, A.J. Modelos biométricos aplicados ao melhoramento genético. Viçosa: Imprensa Universitária, 1997. 390p. 
CRUZ, E.D.; ALVES, R.M.; BENCHIMOL, R.L. Avaliação de clones de cupuaçuzeiro (Theobroma grandiflorum (Willd ex Spreng) Schumm) quanto a tolerância à vassoura-de-bruxa (Crinipellis perniciosa (Stahel) Singer). Belém: Embrapa Amazônia Oriental, 2000. 4p. (Comunicado Técnico, 28)

CRUZ, E.D.; ALVES, R.M. Avaliação de clones de cupuaçuzeiro, Theobroma grandiflorum (Willd ex Spreng) Schum, na Amazônia Oriental. In: SIMPÓSIO DE RECURSOS GENÉTICOS PARA A AMÉRICA LATINA E CARIBE, 3., Londrina. 2001. Anais. Londrina: IAPAR/Embrapa Recursos Genéticos e Biotecnologia, 2001. p.281-283.

CUATRECASAS, J. A. Cocoa and its aliies: a taxonomic revision of the genus Theobroma. Contributions from the United States National Herbarium, v.35, n.6, p.32-46, 1964.

CURY, R. Dinâmica evolutiva e caracterização de germoplasma de mandioca (Manihot esculenta, Crantz) na agricultura autóctone do sul do Estado de São Paulo. Piracicaba, 1993. 103p. Dissertação (Mestrado) - Escola Superior de Agricultura "Luiz de Queiroz", Universidade de São Paulo.

DAHER, R.F. Diversidade morfológica e isoenzimática em capim elefante (Pennisetum purpureum Schum.) Viçosa, 1993. 110p. Dissertação (Mestrado) - Universidade Federal de Viçosa.

DANTAS, M. Cultivo de plantas perenes na Amazônia. In: SIMPÓSIO DO TRÓPICO ÚMIDO, 1., Belém, 1984, Anais. Belém: EMBRAPA, CPATU, 1986. v.4, p.19-26 (Documentos, 36)

DAYANANDAN, S.; BAWA, K.S.; KESSELI, R. Conservation of microsatellites among tropical trees (Leguminosae). American Journal of Botany, v.84, p.1658-1663, 1997.

DIAS, L.A.S.; KAGEYAMA, P.Y. Variação genética em espécies arbóreas e conseqüências para o melhoramento florestal. Agrotrópica, v.3, n.3, p.119-27, 1991.

DIAS, L.A.S. Divergência genética e fenética multivariada na predição de híbridos e preservação de germoplasma de cacau (Theobroma cacao L.). Piracicaba, 1994. 94p. Tese (Doutorado) - Escola Superior de Agricultura "Luiz de Queiroz", Universidade de São Paulo.

DINIZ, T.D.A.S.; BASTOS, T.X.; RODRIGUES, I.A.; MULLER, C.H.; KATO, A.K.; SILVA, M.M.M. Condições climáticas em áreas de ocorrência natural e de cultivo de guaraná, cupuaçu, bacuri e castanha-do Brasil. Belém: EMBRAPA, CPATU, 1984. (Pesquisa em andamento, 133)

DJĖ, Y.; HEUERTZ, M.; LEFÈBVRE, C.; VEKEMANS, X. Assessment of genetic diversity within and among germplasm accessions in cultivated sorghum using microsatellite markers. Theoretical and Applied Genetics, v.100, p.918-925, 2000. 
DOYLE, J.J.; DOYLE, J.L. Isolation of plant DNA from fresh tissue. Focus, v.12, n.1, p.13-15, 1990.

DUCKE, A. Plantas de cultura precolombiana na Amazônia Brasileira: notas sobre as espécies ou formas espontâneas que supostamente lhes teriam dado origem. Belém: IAN, 1946. 24p. (Boletim Técnico, 8)

ENGELS, J.M.M. Genetic resources of cacao: catalogue of CATIE collection. Turrialba: CATIE Plant Genetic Resources Unit, 1981. 196p. (Technical Bulletin, 7)

ENGELS, J.M.M. A systematic description of cacao clones. I. The discriminative value of quantitative characteristics. Euphytica, v.32, p.377-385, 1983a.

ENGELS, J.M.M. A systematic description of cacao clones. II. The discriminative value of qualitative descriptors and the practical compatibility of the discriminative values of quantitative and qualitative descriptors. Euphytica, v.32, p.387-396, 1983b.

ENRÍQUEZ, G.A.; SORIA, V.J. Selección y estudio de los carácteres útiles de la flor para la identificacíon y descripción de cultivares de cacao. Cacao, v.12, p.8-16, 1967.

ESRI CORPORATE OFFICES REDLANDS. ArcView GIS 3.2a: programa de sistema de informação geografico ESRI Corporate Offices Redlands (software). Boston, 2000.

FALCONER, D.S.; MACKAY, T.F.C. Introduction to quantitative genetics. London: Longman, 1997. 463p.

FALCÃO, M.A.; LLERAS, E. Aspectos fenológicos, ecológicos e de produtividade do cupuaçu (Theobroma grandiflorum Willd ex Spreng Schum). Acta Amazônica, v.13, n.5/6, p.725-735, 1983.

FALCÃO, M.A.; MORAIS, R.R.; CLEMENT, C.R. Influência da vassoura de bruxa na fenologia do cupuaçuzeiro. Acta Amazônica, v.29, n.1, p.3-19, 1999.

FEDOROV, A.A. The structure of the tropical rain forest and speciation in the humid tropics. Journal of Ecology, v.54, p.1-11, 1966.

FERREIRA, M.E.; GRATTAPAGLIA, D. Introdução ao uso de marcadores moleculares em análise genética. 2.ed. Brasília: EMBRAPA, CENARGEN, 1996. 220p.

FIGUEIRA, A.; LAMBERT, S.V.; CARPENTER, D.; PIRES, J.L.; CASCARDO, J.C.M.; ROMANCZYK, L. The similarity of cocoa flavour of fermented seeds from fingerprinted genotypes of Theobroma cacao from Brazil and Malaysia. Tropical Agriculture, v.74, n.2, p.132-139. 1997.

FIGUEIRA, A.V.O.; CASCARDO, J.C.M. Marcadores moleculares no melhoramento. In: DIAS, L.A.S (Ed.). Melhoramento genético do cacueiro. Viçosa: FUNAPE, UFG, 2001. p.385-438. 
FONSECA, C.E.L; ESCOBAR, J.R.; BUENO, D.M. Variabilidade de alguns caracteres físicos e químicos do fruto do cupuaçuzeiro. Pesquisa Agropecuaria Brasileira, v.25, n.7, p.1079-1084, 1990.

FRANKELL, O.H.; SOULÉ, M.S. Conservation and evolution. Cambridge: Cambridge University Press, 1981. 327p.

FRIEMAN, H.P.; RUBIN, J. On some invariant criteria for grouping data. Journal of the American Statistical Association, v.62, p.1159-1178, 1967.

FRYER, J.H. Agreement between patterns of morphological variability and isozyme band phenotypes in pitch pine. Silvae Genetica, v.36, n.5/6, p.199-206, 1987.

FUTUYMA, D.J. Biologia evolutiva. 2.ed. Ribeirão Preto: SBG, 1992. 646p.

GANDARA, F.B. Diversidade genética, taxa de cruzamento e estrutura espacial dos genótipos em uma população natural de Cedrela fissilis Vell. (Meliaceae). Campinas, 1996. 69p. Dissertação (Mestrado) - Universidade Estadual de Campinas.

GOODMAN, M.M.; PATERNIANI, E. The races of maize III choices of the appropriate characters for racial classification. Economic Botany, v.23, p.265-273, 1969.

GRATTAPAGLIA, D. Molecular markers for forest trees: where are we going ? In: BORÉM, A.; GIÚDICE, M.P.; SAKIYAMA, N.S. (Ed.). BIOWORK II: plant breeding in the turn of the millennium. Viçosa: UFV, 1999. p.79-102.

GRIFFITH, J.J. Economia da conservação in situ de recursos genéticos florestais. IPEF, v.35, p.85-92, 1987.

HALL, P.; ORREL, L.C.; BAWA, K. Genetic diversity and mating systemin atropical tree. Carapa guianensis (Meliaceae). American Journal of Botany, v.81, n.9, p.11041111, 1994.

HAMRICK, J.L.; LINHART, Y.B.; MITTON, J.B. Relationships between life history characteristics and eletrophoretically detectable genetic variation in plants. Annual Review of Ecology and Systematics, v.10, p.173-200, 1979.

HAMRICK, J.L. Plant population genetics and evolution. American Journal of Botany, v.69, n.10, p.1685-1693, 1982.

HAMRICK, J.L. The distribution of genetic variation within and among natural plant populations. In: SCHONEWALD-COX, C.M.; CHAMBERS, S.M.; MACBRIDE, B.; THOMAS, L. (Ed.). Genetics and conservation. Menlo Park: The Benjamim/Cummings Publishing Company, 1983. p.335-348.

HAMRICK, J.L.; LOVELESS, M.D. Isozyme variation in tropical trees procedures and preliminary results. Biotropica, v.18, p.201-207, 1986.

HAMRICK, J.L. Isozymes and analysis of genetic structure in plants populations. In: Soltis, D.E.; SOLTIS, P.S. (Ed.). Isozymee and analysis of genetic structure in plant populations. London: Chapman and Hall, 1989. p.335-348. 
HAMRICK, J.L.; GODT, M.J.W. Allozyme diversity in plant species. In: BROWN, A.D.H.; CLEG, M.T.; KAHLER, A.L.; WEIR, B.S. (Ed.). Plant population genetics, breeding and genetic resources. Massachusetts: Sinauer, 1990. p.43-63.

HEDRICK, P.W. Genetics of populations. Sudbury: Jones and Bartlett Publishers, 1999. 552p.

HOMMA, A.K.O.; WALKER, R.T.; CARVALHO, R.A.; CONTO, A.J.; FERREIRA, C.A.P. Razões de risco e rentabilidade na destruição de recursos florestais: o caso de castanhais em lotes de colonos no Sul do Pará. Revista Econômica do Nordeste, v.27, n.3, p.515-535, 1996.

HOMMA, A.K.O. Cronologia da ocupação e destruição dos castanhais no Sudeste paraense. Belém: Embrapa Amazônia Oriental, 2000. 132p.

HOMMA, A.K.O.; CARVALHO, R.A.; MENEZES, A.J.E.A. Extrativismo e plantio racional de cupuaçuzeiros no sudeste paraense: a transição inevitável. (Compact disc). In: CONGRESSO BRASILEIRO DE ECONOMIA E SOCIOLOGIA RURAL, 39., Recife, 2001. Anais. Brasília: SOBER, 2001.

HUSSAINI, S.H.; GOODMAN, M.M.; TIMOTHY, D.H. Multivariate analysis and the geographical distribution of the world collection of finger millet. Crop Science, v.17, n.2, p.257-263, 1977.

JARRET, R.L.; VUYLSTEKE, D.R.; GAWEL, N.J.; PIMENTEL, R.B.; DUNBAR, L.J. Detecting genetic diversity in diploid bananas using PCR and primers from a highty repetitive DNA sequence. Euphytica, v.68, p.69-76, 1993.

JANSEN, D.H. Euglossine bees as long distance pollinators of tropical plants. Science, v.171, p.203-205, 1971.

JEFFERS, J.N.R. Principal component analysis of designed experiments. The Statistician, v.12, p.230-242, 1972.

JOLLIFFE, I.T. Discarding variables in a principal component analysis. I: artificial data. Applied Statistics, v.21, n.2, p.160-173, 1972.

JOLLIFFE, I.T. Discarding variables in a principal component analysis. II: Real data. Applied Statistics, v.21, n.1, p.21-31, 1973.

KAGEYAMA, P.Y. Conservação in situ de recursos genéticos de plantas. IPEF, v.35, p.7-37, 1987.

KHASA, P.D.; CHELIAK, W.M.; BOUSQUET, J. Mating system of Racosperma auriculiforme in a seed production area in Zaire. Canadian Journal of Botany, v.71, p.779-785, 1993.

KERR, W.E.; CLEMENT, C.R. Práticas agrícolas de conseqüências genéticas que possibilitaram aos índios da Amazônia uma melhor adaptação as condições ecológicas da região. Acta Amazônica, v.9, p.392-400, 1980. 
KIJAS, J.M.H.; FOWLER, J.C.S.; THOMAS, M.R. Na evaluation of sequence tagged microsattelite site markers for genetic analysis within Citrus and related species. Genome, v.38, p.349-355, 1995.

KNIGHT, R.; ROGERS, H.H. Incompatibility in Theobroma cacao. Heredity, v.9, p.6977, 1955.

LAGERCRANTZ, U.; ELLEGREN, H.; ANDERSSON, L. The abundance of various polymorphic microsatellite motifs differs between plants and vertebrates. Nucleic Acids Research, v.21, p.1111-1115, 1993.

LANAUD, C.; RISTERUCCI, A.M.; PIERETTI, I.; FALQUE, M.; BOUET, A.; LAGODA, P.J.L. Isolation and characterization of microsattelites in Theobroma cacao L. Molecular Ecology, v.8, p.2141-2143, 1999.

LANDE, R.; SCHEMSKE, D.W.; The evolution of self-fertilization and inbreeding depression in plants. II Empirical observations. Evolution, v.39, n.1, p.41-52, 1985.

LAURENT, V.; RISTERUCCI, A.M.; LANAUD, C. Chloroplast and mitochondrial DNA diversity in Theobroma cacao. Theoretical and Applied Genetics, v.87, p.81-88. 1993.

LEE, S.L.; WICKNESWARI, R.; MAHANI, M.C.; ZAKRI, A.H. Mating system parameters in a tropical tree species, Shorea leprosula Miq. (Dipterocarpaceae), from Malaysian Lowland Dipterocarp Forest. Biotropica, v.32, p.693-702, 2000.

LEWIS, P.O.; ZAYKIN, D. GDA - Genetic date analysis: version 1.0 (d12) for Windows (software). Albuquerque: The University of New Mexico, 1999. 39p.

LEWONTIN, R.C. Twenty-five years ago in genetics: electrophoresis in the development of evolutionary genetics: mile-stone of millstone ? Genetics, v.128, p.657-662, 1991.

LIMA, R.R.; ALENCAR, S.A.; FRADE JÚNIOR, J.M.; BRANDÃO, G.R. Coleta e avaliação de plantas amazônicas de cultura ou de exploração pre'- colombiana: recursos genéticos da região do Solimões. In: SIMPÓSIO DO TRÓPICO ÚMIDO, 1., Belém, 1984. Anais. Belém: EMBRAPA, CPATU, 1986. v.4, p.39-49. (Documentos, 36)

LIMA, R.R.; COSTA, J.P.C. da. Registro de introduções de plantas de cultura précolombiana coletadas na Amazônia Brasileira. Belém: EMBRAPA, CPATU, 1991. 191p. (Série Documentos, 58)

LIMA, R.R.; COSTA, J.P.C. da. Coleta de plantas de cultura pré-colombiana na Amazônia brasileira: I. Metodologia e expedições realizadas para coleta de germoplasma. Belém: EMBRAPA, CPATU, 1997. 148p. (Documentos, 99)

LIMA, R.R.; COSTA, J.P.C. da. Coleta de plantas de cultura pré-colombiana na Amazônia brasileira: II. Trabalhos realizados na sede da Embrapa Amazônia Oriental. Belém: EMBRAPA, CPATU, 1998. 102p. (Documentos, 107) 
LITT, M.; LUTY, J.A. A hypervariable microssatellite revealed by in vitro ampliffication of a dinucleotide repeat within the cardiac muscle actin gene. American Journal Human Genetic, v.44, p.397-401, 1989.

LOPEZ, O.B.; ENRÍQUES, G.A. Inheritance of dry weight and bean shape in cacao. THEORETICAL AND APPLIED GENETICS RESEARCH CONFERENCE, 10., Santo Domingo, 1987. Proceedings. Santo Dominingo: Cocoa Producer's Alliance, 1988. p.691-694.

LOVELESS, M.D.; HAMRICK, J.L. Ecological determinants of genetic structure in plant populations. Annual Review of Ecology and Systematics, v.15, p.65-95, 1984.

MACHADO, G.M.E.; RETTO JUNIOR, A. da S. Estudo preliminarsobre biologia floral do cupuaçuzeiro (Theobroma grandiflorum (Willd ex Spreng) Schum). Revista da Universidade do Amazonas, v.1, n.1, p.11-14, 1991.

MALUF, W.R.; FERREIRA, P.E. Análise multivariada da divergência genética em feijão vagem (Phaseolus vulgaris L.). Horticultura Brasileira, v.1, p.31-34, 1983.

MALUF, W.R.; FERREIRA, P.E.; MIRANDA, J.E.C. Genetic divergence in tomatoes and its relationship with heterosis for yield in F1 hybrids. Revista Brasileira de Genética, v.6, n.3, p.453-60, 1983.

MANLY, B.F.J. Randomization, bootstrap and Monte Carlo methods in Biology. London: Chapman \& Hall, 1997. 281p.

MARDIA, K.V.; KENT, J.T.; BIBBY, J.M. Multivariate analysis. London: Academic Press, 1979. 520p.

MARSHALL, J. Fertility in cocoa. In: ANNUAL REPORT ON COCOA RESEARCH, 3., Trinidad, 1933. Proceedings. Port of Spain, 1933. p.34.

MARTINSON, V.A. Embryological studies on hybridization between Theobroma cacao and Theobroma grandiflorum. Canadian Journal of Botany, v.50, p.2117-2124, 1972.

MASCARENHAS, G.C.C.; MIDLEJ, R.R.; TREVISAN, S.D.P. O cluster do cacau no sul da Bahia, Brasil. THEORETICAL AND APPLIED GENETICS RESEARCH CONFERENCE, 13., Kuala Lumpur, 2000. Proceedings. Kuala Lumpur, 2000. (Paper, 72)

MILLER, M.P. TFPGA 1.3: tools for population genetic analyses (software). New York, 1997.

MIRANDA, R.M. Conservação de polpa de cupuaçu (Theobroma grandiflorum, Schum) com o uso do frio. Manaus, 1989. 82p. Dissertação (Mestrado) - Instituto de Pesquisa da Amazônia. 
MORAES, M.L.T. Variabilidade genética por isoenzimas e caracteres quantitativos em duas populações naturais de aroeira Myracrodruon urundeuva F.F. \& M.F.Allemão. Anacardiaceae (Syn: Astronium urundeuva (FR. Allemão) Engler. Piracicaba, 1992. 139p. Tese (Doutorado) - Escola Superior de Agricultura "Luiz de Queiroz", Universidade de São Paulo.

MORAES, V.H. de F.; MULLER, C.H.; SOUZA, A. das G.; ANTÔNIO, I.C. Native fruit species of economic potential from the brazilian Amazon. Angewandte Botanik, v.68, p.47-52, 1994.

MORAIS, O.O. Análise multivariada da divergência genética dos progenitores, índices de seleção e seleção combinada numa população de arroz oriunda de intercruzamentos, usando a macho-esterelidade. Viçosa, 1992. 251p. Tese (Doutorado) - Universidade Federal de Viçosa.

MORGANTE, M.; OLIVIERI, A.M. PCR-amplified microsattelites as markers in plant genetics. The Plant Journal, v.3, p.175-182, 1993.

MOTAMAYOR, J.C.; RISTERUCCI, A.M.; LOPEZ, A.P.; LANAUD, C. Domestication du cacaoyer cultivés par les Mayas. I. Preuve d'une origine sud américaine des cacaoyers cultivés par les mayas. In: THEORETICAL AND APPLIED GENETICS RESEARCH CONFERENCE, 13., Lagos, 2001. Proceedings. Lagos: Cocoa Producers' Alliance, 2001. 54-68.

MÜLLER, C.H.; CARVALHO, J.E.U.; Sistemas de propagação e técnicas de cultivo do cupuaçuzeiro (Theobroma grandiflorum). In: SEMINÁRIO INTERNACIONAL SOBRE PIMENTA-DO-REINO E CUPUAÇU, 1., Belém, 1996. Resumos. Belém: EMBRAPA, CPATU/JICA, 1997. p.57-75. (Documentos, 88)

MURAWSKI, D.A.; HAMRICK, J.L.; HUBBELL, S.P.; FOSTER, R.B. Mating system of two Bombacaceous trees of a neotropical moist forest. Oecologia, v.82, p.501-506, 1990.

MURAWSKI, D.A.; HAMRICK, J.L. The effect of the density of flowering individuals on the mating systems of nine tropical tree species. Heredity, v.67, p.167-174, 1991.

MURAWSKI, D.A.; HAMRICK, J.L. Mating system and phenology of Ceiba pentandra (Bombacaceae) in central Panama. Journal of Heredity, v.83, p.401-404, 1992.

MURAWSKI, D.A. Reproductive biology and genetics of tropical trees from a canopy perspective. In: LOWMAN, M.D.; NADKARMI, N.M. (Ed.). Forest Canopies. New York: Academic Press, 1995. p.457-493.

MURTY, B.R.; ARUNACHALAM, V. The nature of divergence in relation to breeding system in some crop plants. The Indian Journal of Genetics \& Plant Breeding, v.26, n.2, p.188-98, 1966.

N'GORAN, J.A.K.; LAURENT, V.; RISTERUCCI, A.M.; LANAUD, C. Comparative genetic diversity studies of Theobroma cacao L. using RFLP and RAPD markers. Heredity, v.73, p.589-597, 1994. 
$\mathrm{NEI}, \mathrm{M}$. Analysis of gene diversity in subdivided populations. Proceedings of the National Academy of Science of the United States of America, v.70, n.12, p.3321-3323, 1973.

NEI, M. F-statistic and analysis of gene diversity in subdivided populations. Annals of Human Genetics, v.41, p.225-233, 1977.

$\mathrm{NEI}, \mathrm{M}$. Estimation of average heterozygosity and genetic distance from small number of individuals. Genetics, v.89, p.583-590, 1978.

NEI, M. Molecular evolutionary genetics. New York: Columbia University Press, 1987. 512p.

NEVES, M.P.H.; OLIVEIRA, R.P.; MOTA, M.G.C.; SILVA, R.M. Sistema reprodutivo do cupuaçuzeiro (Theobroma grandiflorum): estádios de floração e frutificação. In: CONGRESSO BRASILEIRO DE BOTÂNICA, São Luís, 1993. Anais. São Luís, 1993. p.35.

O'MALLEY, D.M.; BUCKLEY, D.P.; PRANCE, G.T.; BAWA, K.S. Genetics of Brazil nut (Bertholletia excelsa Humb. \& Bonpl.: Lecythidaceae). 2. Mating system. Theoretical and Applied Genetics, v.76, p.929-932, 1988.

OSTENDORF, F.W. Identifying characteres for cacao clones. /Apresentado na Reunião do Comitê Técnico Interamericano de Cacao, Salvador, 1956/

PAIVA, J.R. Variabilidade enzimática em populações naturais de seringueira (Hevea brasiliensis (Willd. ex Adr. de Juss.) Müell. Arg.). Piracicaba, 1992. 145p. Tese (Doutorado) - Escola Superior de Agricultura "Luiz de Queiroz", Universidade de São Paulo.

PAIVA, J.R. KAGEYAMA, P.Y.; VENCOVSKY, R. CONTEL, P.B. Genetics of rubber tree (Hevea brasiliensis (Wild ex Adr de Juss) Müll. Arg.) 1. Genetic variation in natural population. Silvae Genética, v.43, n.5/6, p.307-12, 1994a.

PAIVA, J.R.; KAGEYAMA, P.Y.; VENCOVSKY, R.; CONTEL, P.B. Genetics of rubber tree (Hevea brasiliensis (Wild ex Adr de Juss) Müll. Arg.) 2. Mating system. Silvae Genetica, v.43, n.5/6, p.373-6, 1994b.

PEAKALL, R; GILMORE, S.; KEYS, W.; MORGANT, M.; RAFALSKI, A. Cross-species amplification of soybean (Glycine max) simple-sequence-repeats (SSRs) within the genus and the other legume genera. Molecular Biology and Evolution, v.15, p.1275-1287, 1998.

PEREIRA, A.V. Utilização de análise multivariada na caracterização de germoplasma de mandioca (Manihot esculenta Crantz). Piracicaba, 1989. 180p. Tese (Doutorado) - Escola Superior de Agricultura “Luiz de Queiroz”, Universidade de São Paulo.

PIMENTEL, L.P.; ALVES, R.M. Avaliação de progênies de Cupuaçuzeiro (Theobroma grandiflorum) nas condições de Tomé-açu. In: SEMINÁRIO DE INICIAÇÃO CIENTÍFICA, 5., Belém, 1995. Anais. Belém: EMBRAPA, CPATU/FCAP, 1995. p.153. 
PIRES, C.E.L.S. Diversidade genética de variedades de cana-de-açucar (Saccharum spp.) cultivadas no Brasil. Piracicaba, 1993. 120p. Tese (Doutorado) - Escola Superior de Agricultura "Luiz de Queiroz", Universidade de São Paulo.

POUND, F.J. Studies of fruitfulness in cocoa II. Annual Report on Cocoa Research. Trinidad, 1932. p.26-28.

PRANCE, G.T.; SILVA, M.F. Árvores de Manaus. Manaus: INPA, 1975. p.249-25.

RAO, C.R.; PRASAD, A.S.R.; SAIKRISHNA, T. Genetic divergence among some brown plant thopper resistant rice varieties. Indian Journal of Genetics Plant Breeding, v.41, p.179-185, 1981.

RAO, C.R. Advanced statistical methods in biometric research. New York, Wiley, 1952. 390p.

REIS, M.S. Distribuição e dinâmica da variabilidade genética em populações naturais de palmiteiro (Euterpe edulis Martius). Piracicaba, 1996. 210p. Tese (Doutorado) Escola Superior de Agricultura "Luiz de Queiroz", Universidade de São Paulo.

RESENDE, R.M.S. Aplicação de técnicas de análise multivariada e eletroforese de isoenzimas em estudos de relações fenéticas no gênero Laelia seção Parviflorae. Piracicaba, 1991. 130p. Dissertação (Mestrado) - Escola Superior de Agricultura "Luiz de Queiroz", Universidade de São Paulo.

RIBEIRO, N.C.A.; SACRAMENTO, C.K.; BARRETTO, W.S.; SANTOS FILHO, L.P. Características físicas e químicas de frutos de cupuaçuzeiro (Theobroma grandiflorum) do sudeste da Bahia. Agrotrópica, v.4, n.2, p.33-37, 1992.

RIBEIRO, G.D. Situação atual e perspectivas da cultura do cupuaçuzeiro (Theobroma grandiflorum, Schum) no estado de Rondônia, Brasil. In: SEMINÁRIO INTERNACIONAL SOBRE PIMENTA-DO-REINO E CUPUAÇU, 1., Belém, 1996. Anais. Belém: EMBRAPA, CPATU/JICA, 1997. p.109-118. (Documentos, 89)

RISTERUCCI, A.M.; LANAUD, C.; N'GORAN, J.A.; PIERETTI, I. A saturated linkage map of Theobroma cacao. In: PLANT \& ANIMAL GENOME CONFERENCE, 5., San Diego, 1997. Abstracts. San Diego, 1997. p.332.

RITLAND, K.; JAIN, S. A model for the estimation of outcrossing rate and gene frequencies using independent loci. Heredity, v.47, p.35-52, 1981.

RITLAND, K. Correlated matings in the partial selfer Mimulus guttatus. Evolution, v.43, p.848-859, 1989.

RITLAND, K. Multilocus mating system program MLTR: version 1.1. University of British Columbia, 1997. http//genetics.forestry.ubc.ca/ritland/programs.html. (15 Dec. 1999)

RIVERA, R.; EDWARDS, K.J.; BARKER, J.H.A.; ARNOLD, G.M.; AYAD, G.; HODGKIN, T.; KARP, A. Isolation and characterization of polymorphic microsatellites in Cocos nucifera L. Genome, v.42, p.668-675, 1999. 
ROCHA, O.J.R.; AGUILAR, G. Variation in the breeding behavior of the dry forest tree Enterolobium cyclocarpum (Guanacaste) in Costa Rica. American Journal of Botany, v.89, p.1600-1606, 2001.

RODER, M.S.; PLASCHKE, J.; KONIG, S.U.; BORNER, A.; SORRELLS, M.A.; TANKSLEY, S.D.; GANAL, M.W. Abundance, variability and chromosomal location of microsatellites in wheat. Molecular \& Genetic, v.246, p.327-333, 1995.

RODRIGUES, D.M.; SANTANA, A.C. de. Aspectos da produção e da comercialização do cupuaçu (Theobroma grandiflorum, Schum) no estado do Pará. In: SEMINÁRIO INTERNACIONAL SOBRE PIMENTA-DO-REINO E CUPUAÇU, 1., Belém, 1996. Anais. Belém: EMBRAPA, CPATU/JICA, 1997. p.351-360. (Documentos, 89)

RONGWEN, J.; AKKAYA, M.S.; BHAGWAT, A.A.; LAVI, U.; CREGAN, P.B. The use of microsatellite DNA markers for soybean genotype identification. Theoretical and Applied Genetics, v.90, p.43-48, 1995.

SAS INSTITUTE. SAS/STAT guide for personal computers: version 6. Cary, 1989. 1686p.

SCHULTES, R.E. The Amazonia as a source of new economic plants. Economic Botany, v.33, p.258-266, 1979.

SEBBENN, A.M. Estrutura genética de subpopulações de Genipa americana L. (RUBIACEAE) em mata ciliar a partir de isoenzimas. Piracicaba, 1997. 107p. Dissertação (Mestrado) - Escola Superior de Agricultura "Luiz de Queiroz", Universidade de São Paulo.

SEBBENN, A.M.; SEOANE, C.E.S.; KAGEYAMA, P.Y.; VENCOVSKY, R. Efeitos do manejo na estrutura genética de populações de caixeta (Tabebuia cassinoides). Scientia Forestalis, n.58, p.127-143, 2000.

SEBBENN, A.M.; SEOANE, C.E.C.; KAGEYAMA, P.Y.; LACERTA, C.M. Estrutura genética em populações de Tabebuia cassiroides: implicações para o manejo florestal e conservação genética. Revista do Instituto Florestal, v.13, n.2, p.99111, 2001.

SEOANE, C.E.S.; SEBBENN, A.M.; KAGEYAMA, P.Y. Sistema de reprodução em populações de Esenbeckia leiocarpa Engl. Revista do Instituto Florestal, v.13, n.1, p.19-26, 2001.

SERENO, M.L.; FIGUEIRA, A.; ALBUQUERQUE, P.S.B. Estimación de la diversidad genética de poblaciones silvestres de Theobroma cacao L. Amazónico Brasileño, mediante microsatélites. In: SIMPÓSIO DE RECURSOS GENÉTICOS PARA A AMÉRICA LATINA E CARIBE, 3., Londrina, 2001. Anais. Londrina: EMBRAPA, 2001. p.418-420.

SILVA, R.M. Estudo do sistema reprodutivo e divergência genética em cupuaçuzeiro (Theobroma grandiflorum Willd. ex Spreng.) Schum. Piracicaba, 1996. 151p. Dissertação (Mestrado) - Escola Superior de Agricultura "Luiz de Queiroz", Universidade de São Paulo. 
SINGH, V.P.; SWAMINATHAN, M.S.; MEHRA, R.B.; SIDDIQ, E.A. Divergence among dwarfs of cultivated rice. The Indian Journal of Genetics \& Plant Breeding, v.39, n.2, p.315-322, 1979.

SLATKIN, M. A mesure of population subdivision based on microsatellite allele frequencies. Genetics, v.139, p.457-462, 1995.

SMITH, N.J.H.; WILLIAMS, J.T.; PLUCKNETT, D.L.; TALBOT, J.P. Tropical forests and their crops. London: Comstock Publishing Associates, 1992. 482p.

SMITH, D.N.; DEVEY, M.E. Occurrenceand inheritance of microsatellites in Pinus radiata. Genome, v.37, p.977-983, 1994.

SNEATH, P.H.A.; SOKAL, R.R. Numerical taxonomic. San Francisco: W.R. Freeman, 1973. 573p.

SOARES, L. Melhoramento de batata-baroa (Arracacia xanthorrhiza Bancroft): divergência genética entre clones com base em procedimentos multivariados $\mathrm{e}$ estimativas de parâmetros genéticos. Viçosa, 75p. 1991. Dissertação (Mestrado) Universidade Federal de Viçosa.

SOUZA, A. das G.C.; SILVA, S.E.L da. Avaliação da produção de clones de cupuaçuzeiro (Theobroma grandiflorum (Willd. ex Spreng, Schum). In: WORKSHOP SOBRE AS CULTURAS DA PUPUNHA E CUPUAÇÚ, 1., Manaus, 1996, Anais. Manaus: EMBRAPA, CPAA, 1996a. p.127-135. (Documento, 6)

SOUZA, A. das G.C.; SOUZA, N.R.; SILVA, S.E.L.; NUNES, C.D.M.; CANTO, A.C.; CRUZ, L.A.A. Fruteiras da Amazônia. Brasília: EMBRAPA, SPI, 1996b. 204p.

SOUZA, A. das G.C.; SILVA, S.E.L da. Avaliação da produção de clones de cupuaçuzeiro (Theobroma grandiflorum (Willd. ex Spreng, Schum). In: SEMINÁRIO INTERNACIONAL SOBRE PIMENTA-DO-REINO E CUPUAÇU, 1., Belém, 1996. Anais. Belém: EMBRAPA, CPATU/JICA, 1997. p.147-150. (Documentos, 89)

SOUZA, A. das G.C.; SILVA, S.E.L.; SOUZA, N.R. Avaliação de progênies de cupuaçuzeiro (Theobroma grandiflorum (Willd. ex Spreng, Schum) em Manaus. Revista Brasileira de Fruticultura, v.20, n.3, p.307-312, 1998.

SOUZA, A. das G.C.; SOUZA, N.R. Banco Ativo de germoplasma de cupuaçu (Theobroma grandiflorum (Willd. ex Spreng. Schum.). In: WORKSHOP PARA CURADORES DE BANCO DE GERMOPLASMA DE ESPÉCIES FRUTÍFERAS, 1. ., Brasília, 1997. Anais. Brasília: Embrapa Recursos Genéticos e Biotecnologia, 1999a. p. 107-113.

SOUZA, C.A.S.; DIAS, L.A.S. Melhoramento ambiental e sócio-economia. In: DIAS, L.A.S. (Ed.). Melhoramento genético do cacaueiro. Viçosa: FUNAPE/UFG, 2001. p.1-48.

SOUZA, J.C. Divergência genética entre acessos de Acerola (Malpighia sp.) com base em dados isozimáticos e agronômicos. Viçosa, 67p. 1996. Dissertação (Mestrado) Universidade Federal de Viçosa. 
SQUILLACE, A.E. Average genetic correlations among offspring from open-pollinated forest trees. Silvae Genetica, v.23, p.149-156, 1974.

STATSOFT, INC. Statistica for windows: computer program manual. Tulsa, 1996.

STEINKELLNER, H.; LEXER, C.; TURETSCHEK, E.; GLÖSSL,J. Conservation of (GA)n microssatelites loci between Quercus species. Molecular Ecology, v.6, n.12, p.1189-1194, 1997a.

STEINKELLNER, H.; FLUCH, S.; TURETSCHEK, E.; LEXER, C.; STREIFF, R.; KREMER, A.; BURG, K.; GLÖSSL, J. Identification and characterization of vation of (GA/CT)n microssatelite loci from Quercus petraea. Plant Molecular Biology, v.33, p.1093-1096, 1997b.

STRAPASSON, E. Seleção de descritores na caracterização de germoplasma de Paspalum através de componentes principais. Piracicaba, 1997. 95p. Dissertação (Mestrado) - Escola Superior de Agricultura "Luiz de Queiroz", Universidade de São Paulo.

SUN, M.; RITLAND, K. Mating system of yellow starthistle (Centaurea solstitialis), a successful colonizer in North America. Heredity, v.80, p.225-232, 1998.

SWOFFORD, D.L.; SELANDER, R.B. Biosys-1: a computer program analysis of allelic variation in population genetics and biochemical systematics (software). Champaign: Illinois Natural History Survey, 1989. 43p.

TELLES, M.P.C.; SILVA, R.S.M.; CHAVES, L.J.; COELHO, A.S.G.; DINIZ FILHO, J. A.F. Divergência entre subpopulações de cagaiteira (Eugenia dysenterica) em resposta a padrões edáficos e distribuição espacial. Pesquisa Agropecuaria Brasileira, v.36, n.11, p.1387-1394, 2001.

THOMAS, M.R.; SCOTT, N.S. Microsattelite repeats in grapevine reveal DNA polymorphisms when analysed as sequence-tagged sites. Theoretical and Applied Genetics, v.86, p.985-990, 1993.

UHL, C.; BEZERRA, O.; MARTINI, A. Ameaça à biodiversidade na Amazônia Oriental. Belém: Imazon, 1997. 97p.

UPADHYAY, M.K; MURTY, B.R. Genetic divergence in relation to geographical distribution in pearl millet. The Indian Journal of Genetics \& Plant Breeding, v.30, n.3, p.704-15, 1970.

VAN LAAR, A. Multivariate analysis: a way to better understanding of complexity. South African Forestry Journal, v.141, p.34-41, June 1987.

VARMA, N.S.; GULATI, S.C. Genetic divergence in 2-rowed and 6 rowed barley. The Indian Journal of Genetics \& Plant Breeding, v.42, n.3, p.314-318, 1982.

VASCONCELOS, M.N.L.; SILVA, M.L. da; MAIA, J.G.S.; GOTTLIEB, O.R. Estudo químico das sementes do cupuaçu. Acta Amazônica, v.5, n.3, p.293-295, 1975. 
VEASEY, E.A. Variabilidade genética en acessos de espécies de Sesbania Scop. (Leguminosae): caracterização morfológica, agronômica e isoenzimática. Piracicaba, 1998. 142p. Tese (Doutorado) - Escola Superior de Agricultura "Luiz de Queiroz", Universidade de São Paulo.

VENCOVSKY, R. Tamanho efetivo populacional na coleta e preservação de germoplasma de espécies alógamas. IPEF, v.35, p.79-84, 1987.

VENTURIERI, G.A.; AGUIAR, J.P.L. Composição do chocolate caseiro de amêndoas de cupuaçu (Theobroma grandiflorum (Willd ex Spreng)Schum). Acta Amazônica, v.18, n.1/2, p.3-8, 1988.

VENTURIERI, G.A. Cupuaçu: a espécie, sua cultura, usos e processamento. Belém: Clube do Cupu, 1993. 108p.

VENTURIERI, G.A. Floral biology of cupuassu (Theobroma grandiflorum (Willdenow ex Sprengel) Schumann). Reading, 1994. 206p. Thesis (Ph.D.) - University of Reading.

VENTURIERI, G.A.; RIBEIRO FILHO, A. A. Polinização manual do cupuaçuzeiro (Theobroma grandiflorum). Acta Amazônica, v.25, n.3/4, p.181-191, 1995.

VENTURIERI, G.C.; MAUÉS, M.M; MIYANAGA, R. Polinização do cupuaçuzeiro (Theobroma grandiflorum, STERCULIACEAE): um caso de cantarofilia em uma fruteira amazônica. In: SEMINÁRIO INTERNACIONAL SOBRE PIMENTA-DOREINO E CUPUAÇU, 1., Belém, 1996. Anais. Belém: EMBRAPA, CPATU/JICA, 1997. p.341-350. (Documentos, 89)

VILLACHICA, H.; CARVALHO, J.E.U. de; MÜLLER, C.H.; CAMILO DIAZ, S.; ALMANZA, M. Frutales y hortalizas promisorios de la Amazonia. Lima: FAO, 1996. 376p.

WEIR, B.S. Genetic data analysis: methods for discretetion genetic data. Sunderland: Sinauer Associates, 1996. 377p.

WILCHES, M.O. Evaluacion de 34 variedades de mani mediante tecnicas multivariadas. Revista ICA, v.18, p.67-76, 1983.

WORKMAN, P.; NISWANDER, J.L. Population studies on southwestern Indian tribes. II. Local genetic differentiation in the Papago. American Journal of Human Genetics, v.22, p.24-49, 1970.

WRIGHT, S. Systems of mating. Genetics, v.6, p.111-178, 1921.

WRIGHT, S. Evolution in mendelian population. Genetics, v.16, p.97-159, 1931.

WRIGHT, S. The genetical structure of populations. Annals of Eugenics, v.15, p.323354, 1951.

WRIGHT, S. The interpretation of population structure by F-statistics with special regard to systems of mating. Evolution, v.19, p.395-420, 1965. 
YAMADA, M.M.; BARTLEY, B.G.D.; MELO, G.R.P. Herança do fator compatibilidade em Theobroma cacao L. I. Relações fenotípicas na família PA (Parimari). Revista Theobroma, v.12, n.3, p.163-167, 1982.

YONEYAMA, S.; NUNES, A.M.L.; DUARTE, M.L.R.; SHIMIZU, O.; ENDO, T.; ALBUQUERQUE, F.C. Controle químico da vassoura-de-bruxa em cupuaçuzeiro. In: SEMINÁRIO INTERNACIONAL SOBRE PIMENTA-DO-REINO E CUPUAÇU, 1. Belém, 1996. Anais Belém: EMBRAPA, CPATU/JICA, 1997. p.161-172. (Documentos, 89)

ZHAO, X. P.; KOCHERT, G. Phylogenetic distribution and genetic mapping of a (GGC) microsatellite from rice (Oryza sativa L.). Plant Molecular Biology, v.21, p.607-614, 1993. 